\title{
Alternative Refrigerant Evaluation for High-Ambient-Temperature Environments: R-22 and R-410A Alternatives for Mini-Split Air Conditioners
}

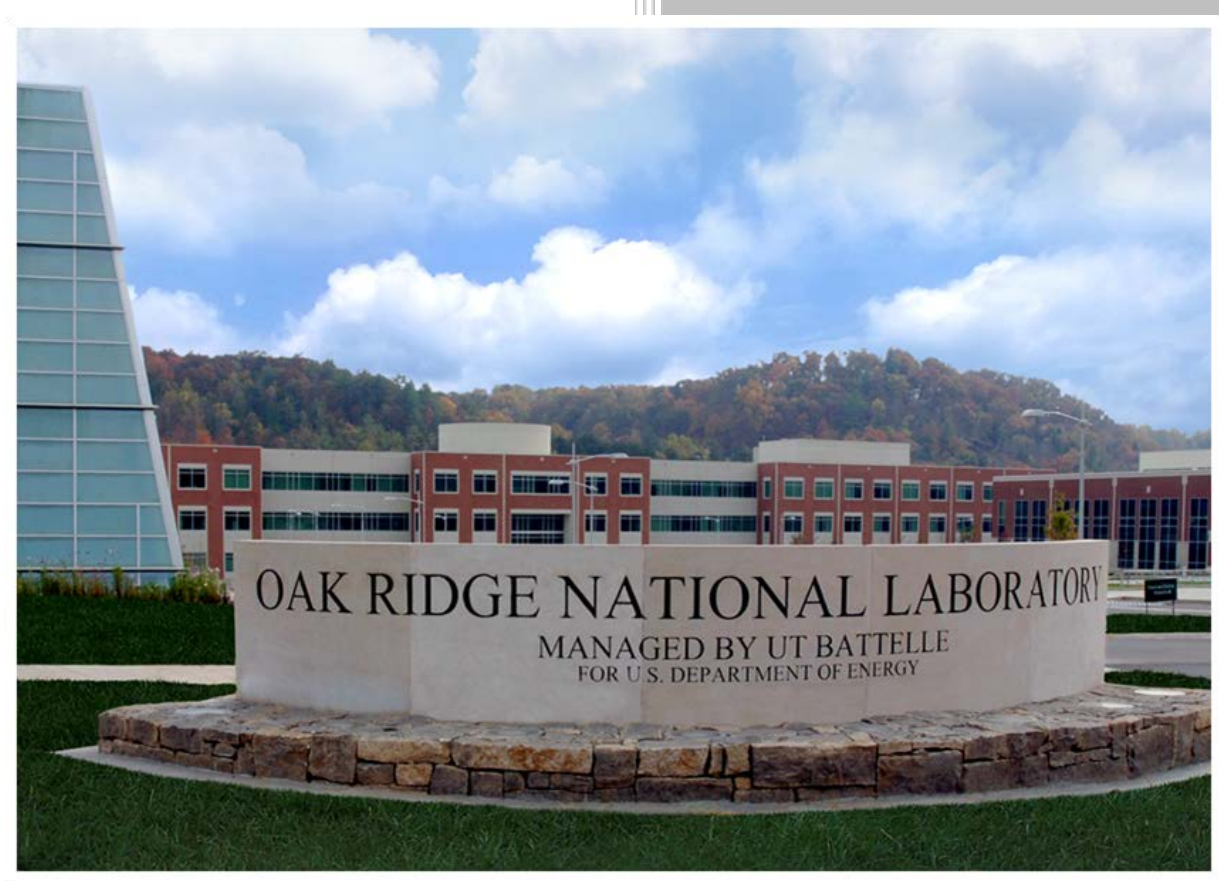

Approved for public release. Distribution is unlimited.
Omar Abdelaziz Som Shrestha Jeffrey Munk Randall Linkous William Goetzler Matthew Guernsey Theo Kassuga

October 2015 


\title{
DOCUMENT AVAILABILITY
}

Reports produced after January 1, 1996, are generally available free via US Department of Energy (DOE) SciTech Connect.

\section{Website http://www.osti.gov/scitech/}

Reports produced before January 1, 1996, may be purchased by members of the public from the following source:

\author{
National Technical Information Service \\ 5285 Port Royal Road \\ Springfield, VA 22161 \\ Telephone 703-605-6000 (1-800-553-6847) \\ TDD 703-487-4639 \\ Fax 703-605-6900 \\ E-mail info@ntis.gov \\ Website http://www.ntis.gov/help/ordermethods.aspx
}

Reports are available to DOE employees, DOE contractors, Energy Technology Data Exchange representatives, and International Nuclear Information System representatives from the following source:

Office of Scientific and Technical Information

PO Box 62

Oak Ridge, TN 37831

Telephone 865-576-8401

Fax 865-576-5728

E-mail reports@osti.gov

Website http://www.osti.gov/contact.html

This report was prepared as an account of work sponsored by an agency of the United States Government. Neither the United States Government nor any agency thereof, nor any of their employees, makes any warranty, express or implied, or assumes any legal liability or responsibility for the accuracy, completeness, or usefulness of any information, apparatus, product, or process disclosed, or represents that its use would not infringe privately owned rights. Reference herein to any specific commercial product, process, or service by trade name, trademark, manufacturer, or otherwise, does not necessarily constitute or imply its endorsement, recommendation, or favoring by the United States Government or any agency thereof. The views and opinions of authors expressed herein do not necessarily state or reflect those of the United States Government or any agency thereof. 


\title{
ALTERNATIVE REFRIGERANT EVALUATION FOR HIGH-AMBIENT- TEMPERATURE ENVIRONMENTS: R-22 AND R-410A ALTERNATIVES FOR MINI-SPLIT AIR CONDITIONERS
}

\author{
Omar Abdelaziz, Som Shrestha, Jeffrey Munk, Randall Linkous, \\ William Goetzler,* Matthew Guernsey*, and Theo Kassuga*
}

*Navigant Consulting, Inc., Burlington, Massachusetts 01803

Date Published: October 2015

\author{
Prepared by \\ OAK RIDGE NATIONAL LABORATORY \\ Oak Ridge, TN 37831-6283 \\ managed by \\ UT-BATTELLE, LLC \\ for the \\ US DEPARTMENT OF ENERGY \\ under contract DE-AC05-00OR22725
}





\section{ACKNOWLEDGEMENTS}

We would like to acknowledge the international expert panel members and the co-chairs, Dr. Patrick Phelan, ${ }^{*}$ Emerging Technologies Program Manager at the US Department of Energy Building Technologies Office, and Dr. Suely Machado Carvalho, adviser to the Superintendent at the Instituto de Pesquisas Energéticas e Nucleares (CNEN/MCTI) Brazil, for their support and guidance of the evaluation program and review of test results and reports.

We would also like to acknowledge Mr. Antonio Bouza, Technology Manager for Heating, Ventilating, and Air Conditioning (HVAC), Water Heating, and Appliances Research at the US Department of Energy Building Technologies Office for his continued support.

The authors would also like to acknowledge the international expert panel for their role in guiding the research work and providing critical review to the experimental data and published documents:

Dr. Radhey Agarwal (India)

Dr. Karim Amrane (USA)

Dr. Enio Bandarra (Brazil)

Dr. J. Bhambure (India)

Dr. Suely Machado Carvalho (co-chair; Brazil)

Mr. Ayman El-Talouny (United Nations Environment Programme)

Dr. Tingxun Li (China)

Dr. Samuel Yana Motta (Peru)

Mr. Maher Moussa (Kingdom of Saudi Arabia)

Mr. Ole Nielsen (United Nations Industrial Development Organization)

Mr. Tetsuji Okada (Japan)

Dr. Alaa Olama (Egypt)

Dr. Alessandro Giuliano Peru (Italy)

Dr. Patrick Phelan (co-chair; USA)

\footnotetext{
* On leave from Arizona State University
} 



\section{TABLE OF CONTENTS}

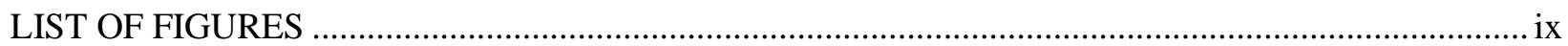

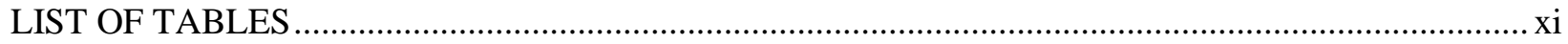

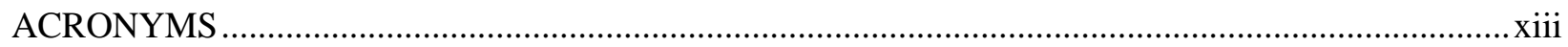

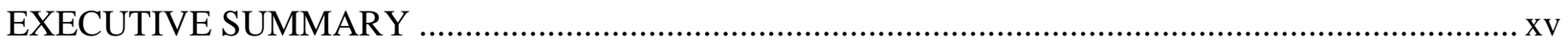

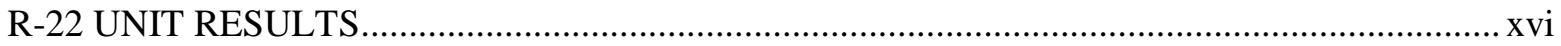

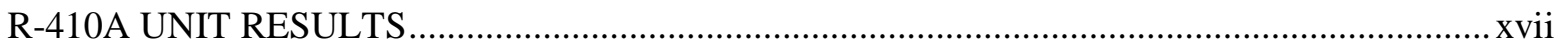

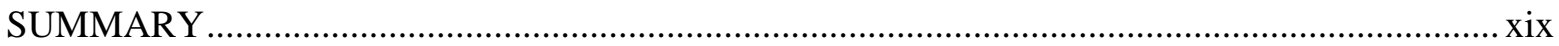

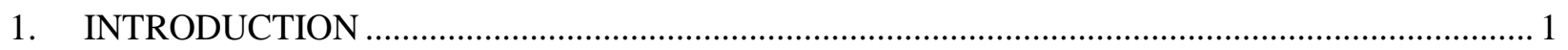

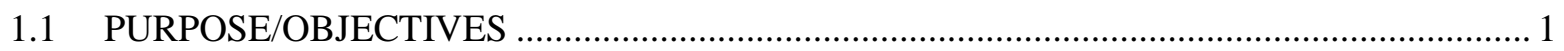

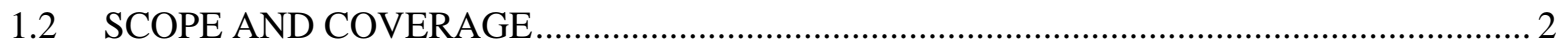

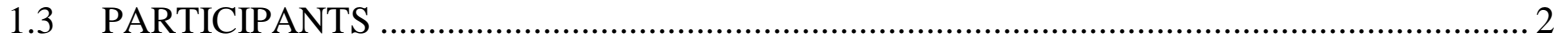

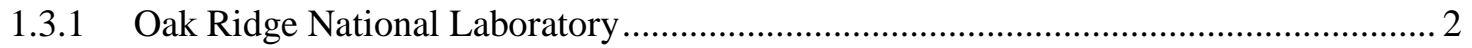

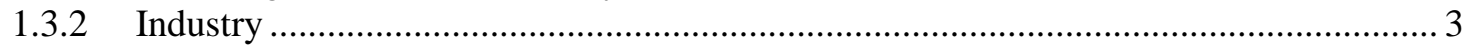

1.3.3 International Expert Panel........................................................................................... 4

2. SELECTION OF ALTERNATIVES AND TESTING CONDITIONS …........................................ 4

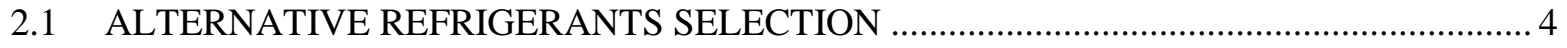

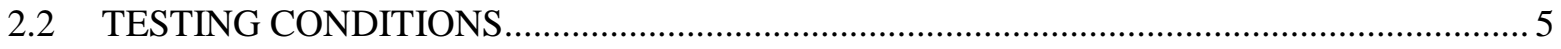

3. OTHER HIGH-AMBIENT-TEMPERATURE EVALUATION EFFORTS .................................... 5

3.1 LOW-GWP ALTERNATIVE REFRIGERANTS EVALUATION PROGRAM ..................... 6

3.2 PROMOTING LOW-GWP REFRIGERANTS FOR THE AIR-CONDITIONING SECTORS IN HIGH-AMBIENT-TEMPERATURE COUNTRIES (PRAHA) ........................ 6

3.3 EGYPTIAN PROGRAM FOR PROMOTING LOW-GWP REFRIGERANTS'

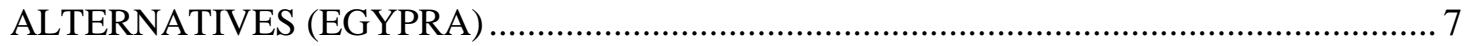

3.4 COMPARISON OF HIGH-AMBIENT-TEMPERATURE TESTING PROGRAMS …........... 7

4. EXPERIMENTAL FACILITIES AND EQUIPMENT ........................................................ 7

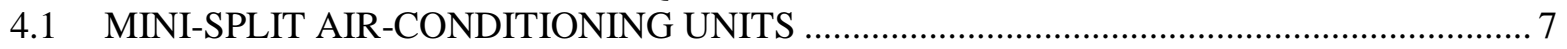

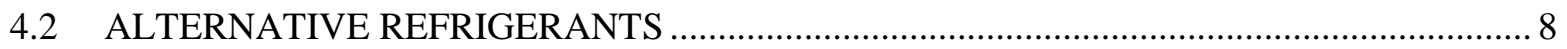

4.2.1 Alternative Refrigerants for the R-22 Unit .......................................................... 8

4.2.2 Alternative Refrigerants for the R-410A Unit ......................................................... 9

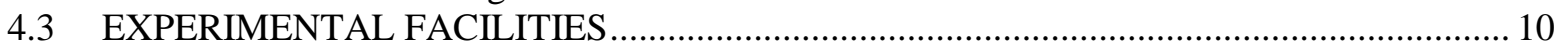

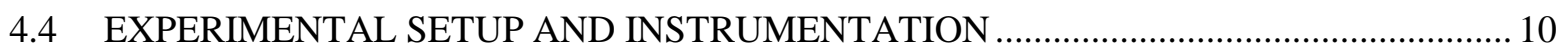

4.5 ALTERNATIVE REFRIGERANT EVALUATION EXPERIMENTAL DESIGN ................. 11

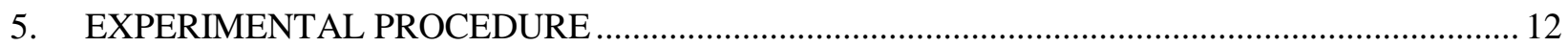

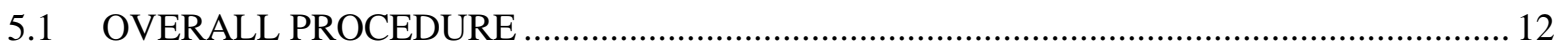

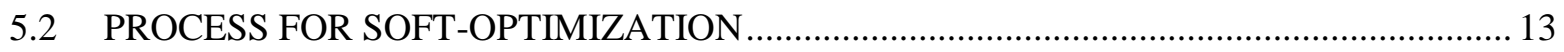

5.3 PROCESS FOR CHANGING REFRIGERANTS AND THE LUBRICANTS ........................ 14

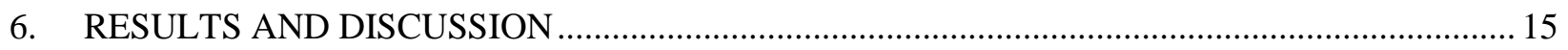

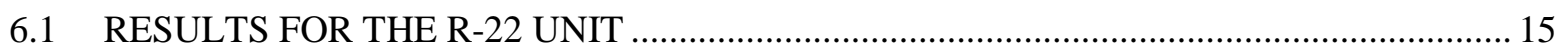

6.1.1 COP and Cooling Capacity Performance............................................................... 18

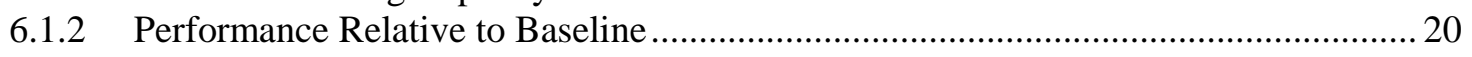

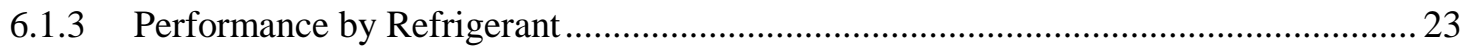

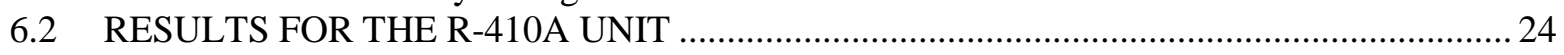

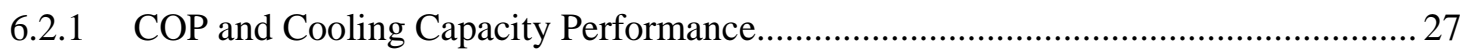

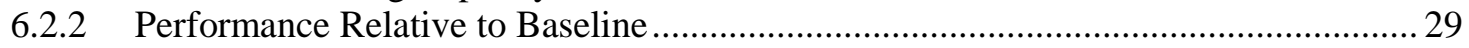

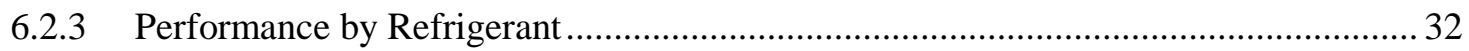

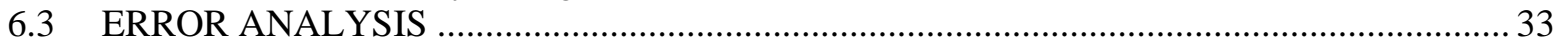

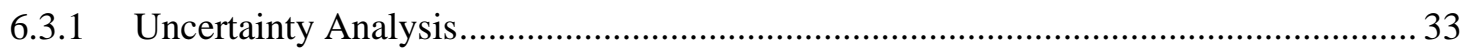

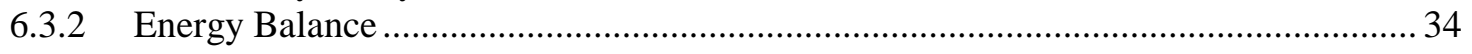




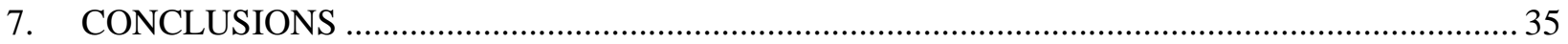

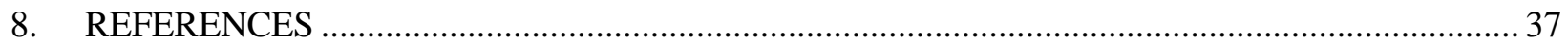

APPENDIX A. EXPERT PANEL-BIOGRAPHIES ................................................................ A-1

APPENDIX B. OTHER HIGH-AMBIENT-TEMPERATURE TESTING PROGRAMS ...................... B-1

APPENDIX C. EXPERIMENTAL TEST SETUP …............................................................................

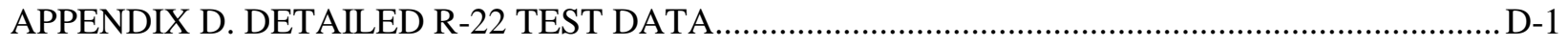

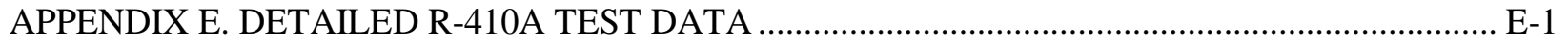

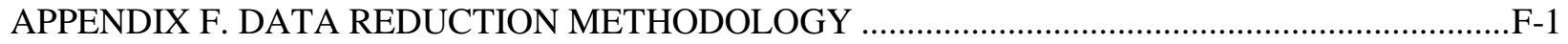

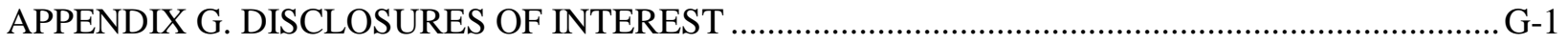




\section{LIST OF FIGURES}

Figure 1. Baseline equipment provided by Carrier designed for high-ambient-temperature conditions

Figure 2. Multi-zone environmental chambers at ORNL BTRIC …............................................... 10

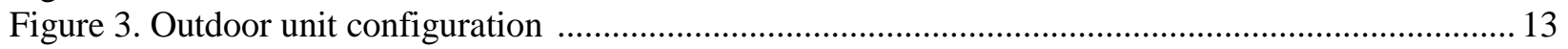

Figure 4. Temperature glide at the evaporator for R-22 and its alternatives ......................................... 16

Figure 5. COP for R-22 and its alternatives at each test condition .................................................... 19

Figure 6. Cooling capacity for R-22 and its alternatives at each test condition ....................................... 19

Figure 7. Performance of alternative refrigerants compared with that of R-22 (mineral oil) at AHRI A test conditions (outdoor temperature $35^{\circ} \mathrm{C}$ and indoor temperature $27^{\circ} \mathrm{C}$ ) ................... 20

Figure 8. Performance of alternative refrigerants compared with R-22 (mineral oil) at ISO T3 (outdoor temperature $46^{\circ} \mathrm{C}$ and indoor temperature $29^{\circ} \mathrm{C}$ )

Figure 9. Performance of alternative refrigerants compared with R-22 (mineral oil) at Hot test conditions (outdoor temperature $52^{\circ} \mathrm{C}$ and indoor temperature $29^{\circ} \mathrm{C}$ ) ...................................... 21

Figure 10. Performance of alternative refrigerants compared with R-22 (mineral oil) at Extreme test conditions (outdoor temperature $55^{\circ} \mathrm{C}$ and indoor temperature $29^{\circ} \mathrm{C}$ ) ................................. 22

Figure 11. Compressor discharge temperature of the alternative refrigerants, difference compared

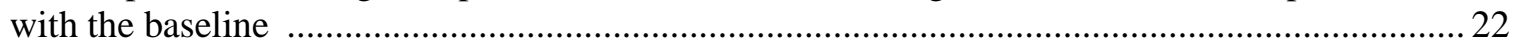

Figure 12. Performance of R-290 compared with R-22 (mineral oil) at each test condition ..................... 23

Figure 13. Performance of R-444B compared with R-22 (mineral oil) at each test condition ................... 23

Figure 14. Performance of ARM-20B compared with R-22 (mineral oil) at each test condition .............. 24

Figure 15. Temperature glide at the evaporator for R-410A and its alternatives ..................................... 25

Figure 16. COP for R-410A and its alternatives at each test condition ................................................ 28

Figure 17. Cooling capacity for R-410A and its alternatives at each test condition ................................. 28

Figure 18. Performance of alternative refrigerants compared with R-410A at AHRI A test

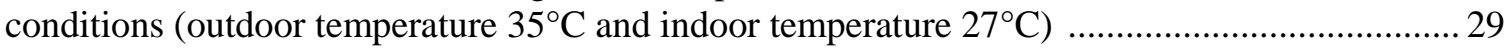

Figure 19. Performance of alternative refrigerants compared with R-410A at ISO T3 (outdoor

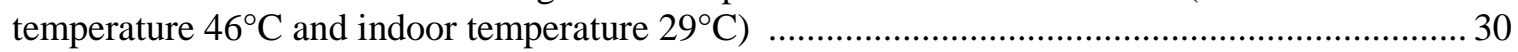

Figure 20. Performance of alternative refrigerants compared with R-410A at Hot test conditions

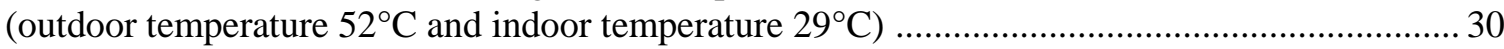

Figure 21. Performance of alternative refrigerants compared with R-410A at Extreme test conditions (outdoor temperature $55^{\circ} \mathrm{C}$ and indoor temperature $29^{\circ} \mathrm{C}$ ) ..................................... 31

Figure 22. Compressor discharge temperature of the alternative refrigerants, difference compared

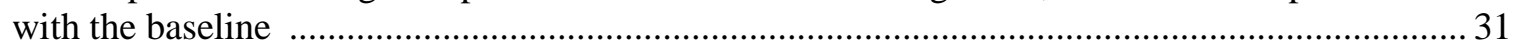

Figure 23. Performance of R-32 compared with R-410A at each test condition ..................................... 32

Figure 24. Performance of DR-55 compared with R-410A at each test condition .................................... 32

Figure 25. Performance of HPR-2A compared with R-410A at each test condition ................................. 33

Figure C.1. Top view of the experimental setup showing both the indoor side and the outdoor side, along with instrumentation locations and design of the air enthalpy tunnel ......................... C-3

Figure C.2. Side view of the air enthalpy tunnel showing additional details and legend for the lines

Figure C.3. As-installed R-22 indoor unit, showing the sampling tree on the return air and the two-layer insulation (R-20 effective insulation)

Figure C.4. R-22 indoor air enthalpy tunnel fully instrumented and connected to the data acquisition system

Figure C.5. R-22 outdoor unit showing Coriolis mass flow meter, pressure and temperature

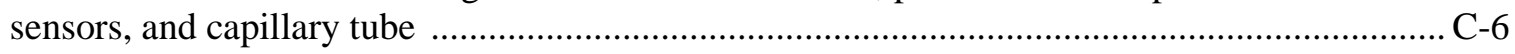

Figure C.6. R-22 original capillary tube downstream of the pressure and temperature sensors .............. C-7 
Figure D.1. COP for R-22 and its alternatives at each test condition, including the additional R-22 (mineral oil rerun and POE run) and R-290 (mineral oil run) results

Figure D.2. Cooling capacity for R-22 and its alternatives at each test condition, including the additional R-22 (mineral oil rerun and POE run) and R-290 (mineral oil run) results ............... D-4

Figure D.3. COP for R-22 and its alternatives at each test condition, relative to the COP of that

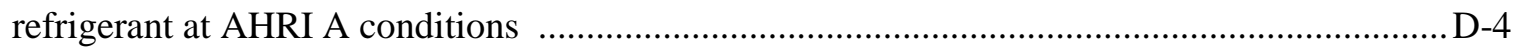

Figure D.4. Cooling capacity for R-22 and its alternatives at each test condition, relative to the cooling capacity of that refrigerant at AHRI A conditions .................................................... D-5

Figure D.5. Condenser subcooling for R-22 and its alternatives at each test condition ......................... D-5

Figure D.6. Evaporator superheat for R-22 and its alternatives at each test condition .......................... D-6

Figure D.7. Compressor discharge temperature for R-22 and its alternatives at each test condition ...... D-6

Figure D.8. Temperature glide at the evaporator for R-22 and its alternatives at each test

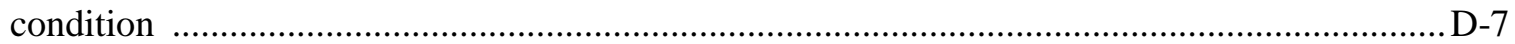

Figure D.9. Performance of alternative refrigerants compared with R-22 (mineral oil) at AHRI A test conditions (outdoor temperature $35^{\circ} \mathrm{C}$ and indoor temperature $27^{\circ} \mathrm{C}$ ), all using the original capillary tube from the R-22 unit

Figure D.10. Performance of alternative refrigerants compared with R-22 (mineral oil) at ISO T3 test conditions (outdoor temperature $46^{\circ} \mathrm{C}$ and indoor temperature $29^{\circ} \mathrm{C}$ ), all using the original capillary tube from the R-22 unit

Figure D.11. Performance of alternative refrigerants compared with R-22 (mineral oil) at Extreme test conditions (outdoor temperature $55^{\circ} \mathrm{C}$ and indoor temperature $29^{\circ} \mathrm{C}$ ), all using the original capillary tube from the R-22 unit

Figure E.1. COP for R-410A and its alternatives at each test condition, including the R-410A rerun

Figure E.2. Cooling capacity for R-410A and its alternatives at each test condition, including the $\mathrm{R}-410 \mathrm{~A}$ rerun

Figure E.3. COP for R-410A and its alternatives at each test condition, relative to the COP of that refrigerant at AHRI A conditions

Figure E.4. Cooling capacity for R-410A and its alternatives at each test condition, relative to the

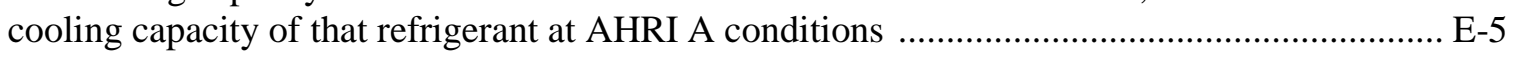

Figure E.5. Condenser subcooling for R-410A and its alternatives at each test condition ..................... E-5

Figure E.6. Evaporator superheat for R-410A and its alternatives at each test condition ...................... E-6

Figure E.7. Compressor discharge temperature for R-410A and its alternatives at each test

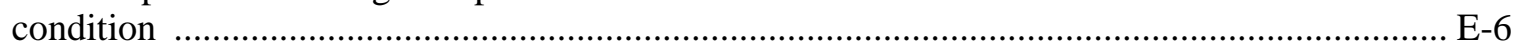

Figure E.8. Temperature glide at the evaporator for R-410A and its alternatives at each test condition

Figure E.9. Performance of alternative refrigerants compared with R-410A at AHRI A test conditions (outdoor temperature $35^{\circ} \mathrm{C}$ and indoor temperature $27^{\circ} \mathrm{C}$ ), all using the original capillary tube from the R-410A unit

Figure E.10. Performance of alternative refrigerants compared with R-410A at ISO T3 (outdoor temperature $46^{\circ} \mathrm{C}$ and indoor temperature $29^{\circ} \mathrm{C}$ ), all using the original capillary tube from the R-410A unit

Figure E.11. Performance of alternative refrigerants compared with R-410A at Extreme test conditions (outdoor temperature $55^{\circ} \mathrm{C}$ and indoor temperature $29^{\circ} \mathrm{C}$ ), all using the original capillary tube from the R-410A unit

Figure F.1. LabView ${ }^{\circledR}$ display of room temperature and fan flow rate …................................................3

Figure F.2. LabView ${ }^{\circledR}$ display of various monitored parameters ……....................................................

Figure F.3. LabView ${ }^{\circledR}$ display of built-in REFPROP calculation ........................................................F-4 


\section{LIST OF TABLES}

Table ES.1. ORNL test plan summary............................................................................... XV

Table ES.2. Baseline and lower-GWP alternative refrigerant characteristics for the R-22 unit........ xvi

Table ES.3. ORNL test results for the R-22 unit at AHRI Standard 210/240 A, B (performance

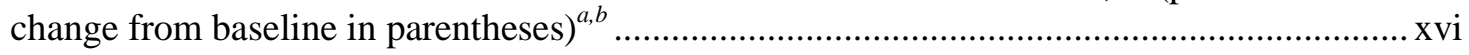

Table ES.4. ORNL test results for the R-22 unit at hot and extreme conditions (performance

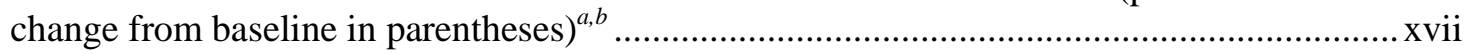

Table ES.5. Baseline and lower-GWP alternative refrigerant characteristics for the R-410A

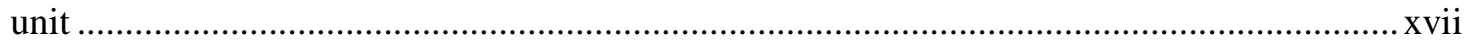

Table ES.6. ORNL test results for the R-410A unit at AHRI Standard 210/240 A, B (performance change from baseline in parentheses) ${ }^{a, b}$............................................................

Table ES.7. ORNL test results for the R-410A unit at hot and extreme conditions

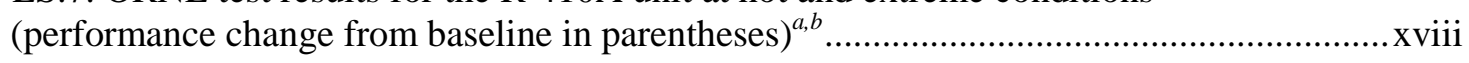

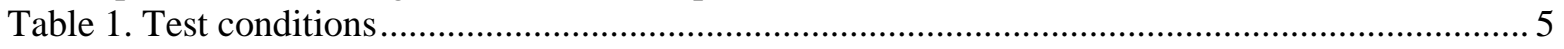

Table 2. Baseline and alternative refrigerant data for the R-22 unit .................................................. 9

Table 3. Baseline and alternative refrigerant data for the R-410A unit ............................................ 9

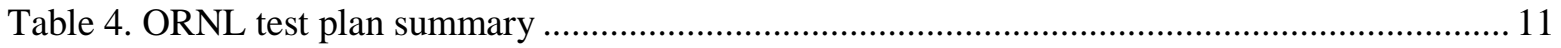

Table 5. Additional tests conducted (not included in original schedule) …....................................... 12

Table 6. Test process nomenclature, subscripts and symbols ........................................................... 14

Table 7. Optimized refrigerant charge masses for the R-22 unit .................................................... 16

Table 8. Test results for R-22 and its alternatives at moderate ambient temperatures

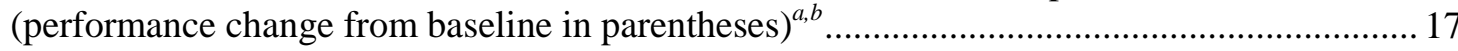

Table 9. Test results for R-22 and its alternatives at the T3* and T3 test conditions

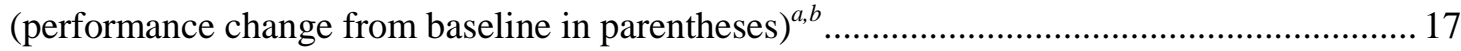

Table 10. Test results for R-22 and its alternatives at high ambient temperatures (performance

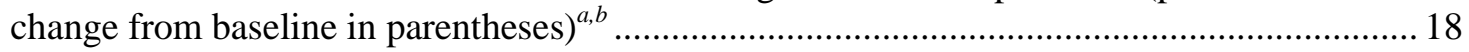

Table 11. Optimized refrigerant charge masses for the R-410A unit ............................................... 25

Table 12. Test results for R-410A and its alternatives at moderate ambient temperatures

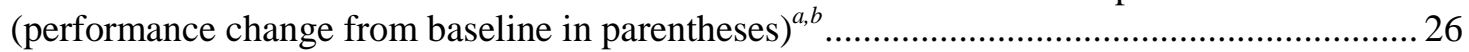

Table 13. Test results for R-410A and its alternatives at the T3* and T3 test conditions

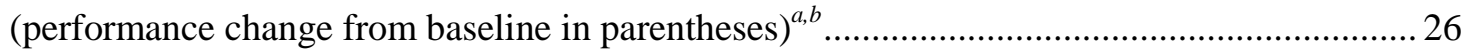

Table 14. Test results for R-410A and its alternatives at high ambient temperatures

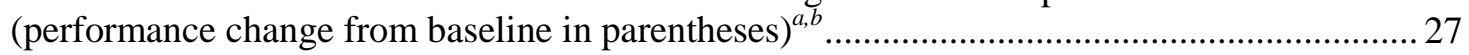

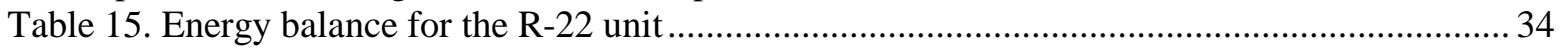

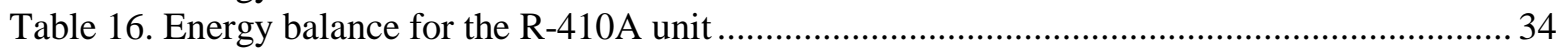

Table B.1. Comparison of high-ambient-temperature testing programs......................................... B-3

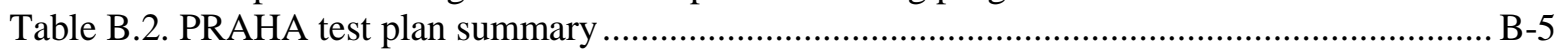

Table B.3. Low-GWP AREP Phase I high-ambient-temperature test matrix............................... B-6

Table B.4. Low-GWP AREP Phase II high-ambient-temperature test matrix .............................. B-6

Table C.1. R-22 unit experimental setup instrumentation .......................................................... C-8

Table C.2. R-410A unit experimental setup instrumentation ..................................................... C-9

Table D.1. Additional test data for the R-22 unit...................................................................

Table D.2. Additional test data for the R-22 unit using the original capillary tube....................... D-17

Table E.1. Additional test data for the R-410A unit ................................................................. E-10

Table E.2. Additional test data for the R-410A unit with the original capillary tube .................... E-15

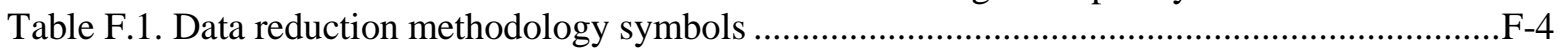

Table F.2. Data reduction methodology subscripts................................................................. 



\section{ACRONYMS}

AC

AHRI

AREP

ASHRAE

ASME

BEE

BIS

BTRIC

CAP

CFC

CFD

CFM

COP

DOE

EER

EGYPRA

EPA

EOS

GWP

HCFC

HFC

HFO

HP

HPDM

HVAC

ID

IIR

IPCC

ISO

JRAIA

LCCP

$\mathrm{MBH}$

MLF

NSCL

OD

ODS

OEM

ORNL

POE

PRAHA

R\&D

RAMA

RTOC

TEAP

TR air conditioner

Air-Conditioning, Heating, and Refrigeration Institute

Alternative Refrigerants Evaluation Program

American Society of Heating, Refrigerating and Air-Conditioning Engineers

American Society of Mechanical Engineers

Bureau of Energy Efficiency

Bureau of Indian Standards

ORNL's Building Technologies Research and Integration Center

Compliance Assistance Programme at UNEP's Regional Office for West Asia

chlorofluorocarbon

computational fluid dynamics

cubic feet per minute

coefficient of performance

US Department of Energy

energy efficiency ratio

Egyptian Program for Promoting Low-GWP Refrigerants’ Alternatives

US Environmental Protection Agency

Egyptian Organization for Standardization and Quality

global warming potential

hydrochlorofluorocarbon

hydrofluorocarbon

hydrofluoroolefin (unsaturated HFC)

heat pump

ORNL's Heat Pump Design Model

heating, ventilating, and air-conditioning

inner diameter

International Institute of Refrigeration

Intergovernment Panel on Climate Change

International Organization for Standardization

Japan Refrigeration and Air-Conditioning Industrial Association

Life Cycle Climate Performance

1,000 British thermal units per hour

Multilateral Fund for the Implementation of the Montreal Protocol

National Superconducting Cyclotron Laboratory

outer diameter

ozone-depleting substance

original equipment manufacturer

Oak Ridge National Laboratory

polyolester (oil)

Promoting Low-GWP Refrigerants for Air-Conditioning Sectors in High Ambient

Temperature Countries

research and development

Refrigeration and Air-Conditioning Manufacturers Association

Refrigeration and Air Conditioning Technical Options Committee of UNEP (also

referred to as the UNEP Technical Options Committee on Refrigeration, Air-

Conditioning, and Heat Pumps)

Technology and Economics Assessment Panel

refrigeration tons 
UNEP

UNIDO

VRF
United Nations Environment Programme

United Nations Industrial Development Organization

variable refrigerant flow 


\section{EXECUTIVE SUMMARY}

The Oak Ridge National Laboratory (ORNL) High-Ambient-Temperature Evaluation Program for lowglobal warming potential (Low-GWP) Refrigerants aims to develop an understanding of the performance of low-GWP alternative refrigerants to hydrochlorofluorocarbon (HCFC) and hydrofluorocarbon (HFC) refrigerants in mini-split air conditioners under high-ambient-temperature conditions. This final report describes the parties involved, the alternative refrigerant selection process, the test procedures, and the final results.

ORNL designed a test matrix of 84 tests. Table ES.1 shows the refrigerants identified for testing by ORNL with guidance from an expert panel. ${ }^{*}$ The expert panel is composed of members from various nations, as well as United Nations Environment Programme and United Nations Industrial Development Organization personnel. Guided by input from the expert panel, ORNL selected the refrigerants based on their GWP, commercial availability, and physical properties, also considering whether information about the characteristics of the refrigerants is readily available. ORNL conducted tests using two "softoptimized" ductless mini-split air conditioners provided by Carrier. ${ }^{\dagger}$ Both units have a cooling capacity of $5.25 \mathrm{~kW}_{\text {th }}(1.5 \mathrm{TR})$. One unit is designed to operate with R-22 refrigerant (2.78 coefficient of performance [COP], equivalent to a 9.5 energy efficiency ratio [EER]). The other is designed to use R-410A refrigerant (3.37 COP, equivalent to an $11.5 \mathrm{EER}) .{ }^{\ddagger}, \S$

Table ES.1. ORNL test plan summary

\begin{tabular}{|c|c|c|c|c|c|c|c|c|c|c|c|c|c|}
\hline & صّ̈ & 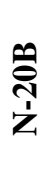 & 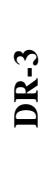 & 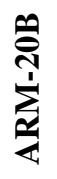 & 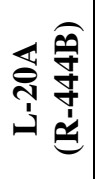 & 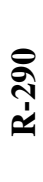 & 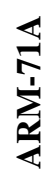 & $\begin{array}{l}\tilde{\alpha} \\
\check{\alpha}\end{array}$ & 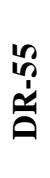 & 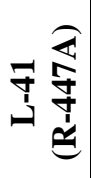 & 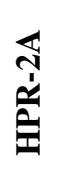 & 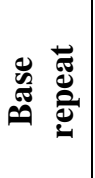 & $\begin{array}{c}\text { Total } \\
\text { no. of } \\
\text { tests }\end{array}$ \\
\hline R-22 unit & $x$ & $x$ & $x$ & $x$ & $x$ & $x$ & & & & & & $x$ & 42 \\
\hline R-410A unit & $x$ & & & & & & $x$ & $x$ & $x$ & $x$ & $x$ & $x$ & 42 \\
\hline
\end{tabular}

Testing was conducted in ORNL's Multi-Zone Environmental Chambers. This facility contains several controlled chambers, which allows for the setup of an outdoor unit and one or more indoor units, each in separate spaces. The test procedure involved soft-optimization (moderate modifications to the units to enable them to run with each refrigerant) and testing at six different environmental testing conditions.

For all refrigerants, including R-22 and R-410A, efficiency degraded with increased ambient temperature. Further, in evaluating the results, it is important to keep in mind that the test units were not designed specifically for the alternative refrigerants, but rather were soft-optimized. As a result, the alternative refrigerants should not be expected to perform as well as they would if the system designs were fully optimized for them.

\footnotetext{
* Additional tests beyond the original test plan were performed; for details, see Section 4.5.

${ }^{\dagger}$ Soft-optimized units are production units that have undergone modifications such as refrigerant charge optimization, lubricant change, and flow control device changes to run with a different refrigerant. This is in contrast with fully optimized units, which are purpose-built for a refrigerant. For details, see Section 1.2.

${ }^{\ddagger}$ Both units were rated at ISO T1 conditions (outdoor temperature: $35^{\circ} \mathrm{C}$; indoor temperature: $27^{\circ} \mathrm{C}$ ).

$\S$ EER is an efficiency metric commonly used in the United States to indicate the cooling performance of air-conditioning equipment. COP is given in $\mathrm{W} / \mathrm{W}$, while EER is in Btu/W•h.
} 


\section{R-22 UNIT RESULTS}

Table ES.2 lists the characteristics of the alternative refrigerants evaluated in the R-22 unit.

Table ES.2. Baseline and lower-GWP alternative refrigerant characteristics for the R-22 unit

\begin{tabular}{|r|c|c|c|c|}
\hline Refrigerant & Manufacturer & $\begin{array}{c}\text { ASHRAE } \\
\text { safety class }\end{array}$ & $\mathbf{G W P}_{\text {AR4 }}{ }^{\boldsymbol{a}}$ & $\mathbf{G W P}_{\text {AR5 }}{ }^{\boldsymbol{a}}$ \\
\hline R-22 (baseline) & - & A1 & 1,810 & 1,760 \\
\hline N-20B & Honeywell & A1 & 988 & 904 \\
DR-3 & Chemours & A2L & 148 & 146 \\
ARM-20B & Arkema & A2L & 251 & 251 \\
L-20A (R-444B) & Honeywell & A2L & 295 & 295 \\
R-290 & - & A3 & 3 & 3 \\
\hline
\end{tabular}

${ }^{a}$ Evaluated as weighted average values of the GWP of the refrigerant blend components provided by the refrigerant manufacturers and the reported GWP values of those components in IPCC AR4, 2007 [1] and IPCC AR5, 2013 [2], respectively.

Table ES.3 summarizes the test results at moderate ambient temperatures (AHRI Standard 210/240 A and B). At each of these two ambient conditions, the results from the R-22 unit showed that all the alternative refrigerants except R-290 (propane) resulted in lower performance than R-22 (in terms of both COP and cooling capacity). R-290 led to lower cooling capacity but higher COP than the baseline.

Table ES.3. ORNL test results for the R-22 unit at AHRI Standard 210/240 A, B (performance change from baseline in parentheses) ${ }^{a, b}$

\begin{tabular}{|r|c|c|c|c|}
\hline & \multicolumn{2}{|c|}{ AHRI B } & \multicolumn{2}{c|}{ AHRI A } \\
& Outdoor: $27.8^{\circ} \mathrm{C}\left(82^{\circ} \mathrm{F}\right)$ & COPtdoor: $35.0^{\circ} \mathrm{C}\left(95^{\circ} \mathrm{F}\right)$ \\
\hline & COP & Capacity & 3.07 & Capacity \\
\hline R-22 (baseline) & 3.48 & 6.26 & $2.68(-13 \%)$ & 5.10 \\
\hline N-20B & $3.04(-13 \%)$ & $5.42(-13 \%)$ & $2.57(-16 \%)$ & $5.40(-14 \%)$ \\
\hline DR-3 & $2.88(-17 \%)$ & $5.52(-12 \%)$ & $2.71(-12 \%)$ & $5.91(-3 \%)$ \\
\hline ARM-20B & $3.06(-12 \%)$ & $6.05(-3 \%)$ & $2.72(-11 \%)$ & $5.58(-9 \%)$ \\
\hline L-20A (R-444B) & $3.02(-13 \%)$ & $5.53(-12 \%)$ & $3.30(+7 \%)$ & $5.62(-8 \%)$ \\
\hline R-290 & $3.85(+11 \%)$ & $5.93(-5 \%)$ & & \\
\hline
\end{tabular}

${ }^{a}$ Shading—green: performance improvement; blank: 0-5\% degradation; yellow: 5-10\% degradation; orange: >10\% degradation.

${ }^{b}$ The $5 \%$ losses may be nullified by further soft-optimization, whereas $10 \%$ losses may require additional engineering, and losses greater than $10 \%$ may require complete redesign of the unit.

Table ES.4 summarizes the results at high ambient temperatures (hot and extreme). At the highestambient-temperature test condition (“extreme” $55^{\circ} \mathrm{C}$ outdoor temperature), the system with R-290 achieved an 8\% higher COP than the baseline with a 9\% drop in cooling capacity. R-444B resulted in only modest performance degradation relative to R-22 at the extreme condition: a 7\% lower COP and 4\% lower cooling capacity than the baseline refrigerant. Also at the extreme condition, ARM-20B had a cooling capacity only $3 \%$ lower than the baseline refrigerant, with an $11 \%$ drop in COP. 
Table ES.4. ORNL test results for the R-22 unit at hot and extreme conditions (performance change from baseline in parentheses) ${ }^{a, b}$

\begin{tabular}{|r|c|c|c|c|}
\hline & \multicolumn{2}{|c|}{ Hot ambient } & \multicolumn{2}{c|}{$\begin{array}{c}\text { Extreme ambient } \\
\text { Outdoor: } 55^{\circ} \mathrm{C}\left(131^{\circ} \mathrm{F}\right)\end{array}$} \\
\hline & COP & Capacity & COP & Capacity \\
\hline R-22 (baseline) & 1.98 & 5.00 & 1.82 & 4.76 \\
\hline N-20B & $1.77(-11 \%)$ & $4.26(-15 \%)$ & $1.64(-10 \%)$ & $4.1(-14 \%)$ \\
\hline DR-3 & $1.7(-14 \%)$ & $4.41(-12 \%)$ & $1.55(-15 \%)$ & $4.21(-12 \%)$ \\
\hline ARM-20B & $1.76(-11 \%)$ & $4.84(-3 \%)$ & $1.61(-11 \%)$ & $4.62(-3 \%)$ \\
\hline L-20A (R-444B) & $1.85(-7 \%)$ & $4.79(-4 \%)$ & $1.69(-7 \%)$ & $4.59(-4 \%)$ \\
\hline R-290 & $2.12(+7 \%)$ & $4.5(-10 \%)$ & $1.96(+8 \%)$ & $4.33(-9 \%)$ \\
\hline
\end{tabular}

${ }^{a}$ Shading - green: performance improvement; blank: 0-5\% degradation; yellow: 5-10\% degradation; orange: >10\% degradation.

${ }^{b}$ The $5 \%$ losses may be nullified by further soft-optimization, whereas $10 \%$ losses may require additional engineering and losses greater than $10 \%$ may require complete redesign of the unit.

Based on the uncertainty analysis, the air-side capacity had an uncertainty of $\pm 2.3 \%$ and the air-side COP had an uncertainty of $\pm 2.4 \%$. Considering these uncertainties and the potential for further performance enhancements, refrigerants with performance values within $5 \%$ of the baseline may be expected to match the performance of R-22 with further soft-optimization. Furthermore, values within $10 \%$ of the baseline indicate an acceptable match that requires additional engineering design to reach parity with R-22 performance. For performance losses greater than $10 \%$, significant redesign of the unit would likely be necessary to match the performance of the baseline. This suggests that, at high ambient temperatures, at least a few alternative refrigerants could be expected to perform at least as well as R-22, if not better, with additional soft-optimization, while others might require additional engineering redesign.

Section 6.1 of this report provides detailed results for the R-22 alternatives at all six ambient temperatures, including the two mid-range ambient temperature points, T3 and T3* (not shown in this executive summary).

\section{R-410A UNIT RESULTS}

Table ES.5 lists the alternative refrigerants evaluated in the R-410A unit and their characteristics.

Table ES.5. Baseline and lower-GWP alternative refrigerant characteristics for the R-410A unit

\begin{tabular}{|r|c|c|c|c|}
\hline \multicolumn{1}{|c|}{ Refrigerant } & Manufacturer & $\begin{array}{c}\text { ASHRAE } \\
\text { safety class }\end{array}$ & $\mathbf{G W P}_{\text {AR4 }}{ }^{\boldsymbol{a}}$ & $\mathbf{G W P}_{\text {AR5 }}{ }^{\boldsymbol{a}}$ \\
\hline R-410A (baseline) & - & A1 & 2088 & 1924 \\
\hline R-32 & Daikin & A2L & 675 & 677 \\
DR-55 & Chemours & A2L & 698 & 676 \\
L-41 (R-447A) & Honeywell & A2L & 583 & 572 \\
ARM-71A & Arkema & A2L & 460 & 461 \\
HPR-2A & Mexichem & A2L & 600 & 593 \\
\hline
\end{tabular}

${ }^{a}$ Evaluated as weighted average values of the GWP of the refrigerant blend components provided by the refrigerant manufacturers and the reported GWP values of those components in IPCC AR4, 2007 [1] and IPCC AR5, 2013 [2], respectively.

Table ES.6 summarizes the results at moderate ambient temperatures (AHRI Standard 210/240 A and B). Three of the alternatives to R-410A resulted in lower COPs and cooling capacity, partly due to the fact that the unit was only soft-optimized and didn't undergo engineering design for zeotropic refrigerant 
mixtures. Nevertheless, the difference between R-410A and these three alternatives was not as significant as the difference between R-22 and its alternatives. One of the other alternatives, R-32, led to both higher COP and higher cooling capacity than the baseline refrigerant at both test conditions. In addition, the system with DR-55 had slightly lower cooling capacity but slightly higher COP than the baseline R-410A at both test conditions.

Table ES.6. ORNL test results for the R-410A unit at AHRI Standard 210/240 A, B (performance change from baseline in parentheses) ${ }^{a, b}$

\begin{tabular}{|r|c|c|c|c|}
\hline & \multicolumn{2}{|c|}{ AHRI B } & \multicolumn{2}{c|}{ AHRI A } \\
& Outdoor: $27.8^{\circ} \mathrm{C}\left(82^{\circ} \mathrm{F}\right)$ & Cutdoor: $35.0^{\circ} \mathrm{C}\left(95^{\circ} \mathrm{F}\right)$ \\
\hline & COP & Capacity & 3.40 & Capacity \\
\hline R-410A (baseline) & 3.95 & 5.35 & $3.55(+4 \%)$ & 5.14 \\
\hline R-32 & $3.99(+1 \%)$ & $5.46(+2 \%)$ & $3.5(+3 \%)$ & $5.42(+5 \%)$ \\
\hline DR-55 & $4.03(+2 \%)$ & $5.15(-4 \%)$ & $3.22(-5 \%)$ & $4.44(-14 \%)$ \\
\hline L41 (R-447A) & $3.62(-8 \%)$ & $4.49(-16 \%)$ & $3.38(-1 \%)$ & $4.75(-8 \%)$ \\
\hline ARM-71A & $3.94(0 \%)$ & $4.97(-7 \%)$ & $3.32(-2 \%)$ & $4.69(-9 \%)$ \\
\hline HPR-2A & $3.69(-7 \%)$ & $4.69(-12 \%)$ & & \\
\hline
\end{tabular}

${ }^{a}$ Shading — green: performance improvement; blank: 0-5\% degradation; yellow: 5-10\% degradation; orange: >10\% degradation.

${ }^{b}$ The 5\% losses may be nullified by further soft-optimization, whereas $10 \%$ losses may require additional engineering, and losses greater than $10 \%$ may require complete redesign of the unit.

Table ES.7 summarizes the results at high ambient temperatures (hot and extreme). At the highestambient-temperature test condition ("extreme" $55^{\circ} \mathrm{C}$ outdoor temperature), R-32 resulted in a $6 \%$ higher COP and 13\% higher cooling capacity than the baseline. All of the other alternatives delivered higher COPs than the baseline, with nearly the same cooling capacity at the extreme test condition. For instance, HPR-2A led to a 6\% higher COP and approximately the same cooling capacity as the baseline. At high ambient temperatures, the results demonstrate that these alternative refrigerants allow for equivalent or better performance than the baseline, in terms of both COP and cooling capacity, for soft-optimized conditions.

Table ES.7. ORNL test results for the R-410A unit at hot and extreme conditions (performance change from baseline in parentheses) ${ }^{a, b}$

\begin{tabular}{|r|c|c|c|c|}
\hline & \multicolumn{2}{|c|}{ Hot ambient } & \multicolumn{2}{c|}{$\begin{array}{c}\text { Extreme ambient } \\
\text { Outdoor: } 55^{\circ} \mathrm{C}\left(131^{\circ} \mathrm{F}\right)\end{array}$} \\
\hline & COP & Capacity & COP & Capacity \\
\hline R-410A (baseline) & 2.07 & 3.98 & 1.87 & 3.75 \\
\hline R-32 & $2.17(+5 \%)$ & $4.43(+11)$ & $1.98(+6 \%)$ & $4.23(+13 \%)$ \\
\hline DR-55 & $2.14(+3 \%)$ & $3.99(0 \%)$ & $1.93(+3 \%)$ & $3.76(0 \%)$ \\
\hline L41 (R-447A) & $2.13(+3 \%)$ & $3.77(-6 \%)$ & $1.96(+5 \%)$ & $3.63(-3 \%)$ \\
\hline ARM-71A & $2.11(+2 \%)$ & $3.83(-4 \%)$ & $1.90(+2 \%)$ & $3.62(-3 \%)$ \\
\hline HPR-2A & $2.16(+5 \%)$ & $3.93(-1 \%)$ & $1.98(+6 \%)$ & $3.77(+1 \%)$ \\
\hline
\end{tabular}

${ }^{a}$ Shading - green: performance improvement; blank: 0-5\% degradation; yellow: 5-10\% degradation; orange: >10\% degradation.

${ }^{b}$ The $5 \%$ losses may be nullified by further soft-optimization, whereas $10 \%$ losses may require additional engineering, and losses greater than $10 \%$ may require complete redesign of the unit. 
Based on the uncertainty analysis, the air-side capacity had an uncertainty of $\pm 1.5 \%$ and the air-side COP had an uncertainty of $\pm 1.6 \%$. Considering these uncertainties and the potential for further performance enhancements, refrigerants with performance values within $5 \%$ of the baseline may be expected to match the performance of R-410A with further soft-optimization. Furthermore, values within $10 \%$ of the baseline indicate an acceptable match that requires additional engineering design to reach parity with R-410A performance. This suggests that, at high ambient temperatures, all of the alternatives to R-410A tested could deliver performance equivalent to, or better than, the baseline. In many cases, achieving such performance would not require further soft-optimization or minor redesign; however, further engineering may still be required to ensure safe and reliable operation.

Section 6.2 of this report provides detailed results for all R-410A alternatives at all six ambient temperatures, including the two mid-range temperature points, T3 and T3* (not shown in this executive summary).

\section{SUMMARY}

The test results from this evaluation program demonstrate that there are several viable alternatives to both R-22 and R-410A at high ambient temperatures. In some cases, there was a significant improvement in the performance of the alternatives over that of the baseline, in terms of both COP and cooling capacity. In other cases, the performance of the alternatives fell within $10 \%$ of the baseline, which suggests that parity with baseline performance would likely be possible through additional engineering design.

The R-22 alternative refrigerants showed promising results at high ambient temperatures: although both of the A1 alternative refrigerants lagged in performance, some of the A2L refrigerants showed capacity within $5 \%$ and efficiency within approximately $10 \%$ of the baseline system. The A3 refrigerant (R-290) exhibited higher efficiency consistently; however, it did not match the cooling capacity of the baseline system. The most promising A2L refrigerants exhibited slightly higher compressor discharge temperatures, while the A3 refrigerant exhibited lower compressor discharge temperatures.

The R-410A alternative refrigerants are all in the A2L safety category. Most of them showed significant potential as replacements. R-32 was the only refrigerant that showed consistently better capacity and efficiency; however, it resulted in compressor discharge temperatures that were $12-21^{\circ} \mathrm{C}$ higher than those observed for the baseline refrigerant. These higher temperatures may negatively impact compressor reliability. DR-55 and HPR-2A had higher COPs than the baseline and matched the capacity of the baseline at both the hot and extreme test conditions. R-447A and ARM-71a had lower cooling capacity than the baseline at all ambient conditions. The system efficiency of R-447A showed improvement over the baseline at high ambient temperatures; for ARM-71a, the efficiency was similar to the baseline at all test conditions.

The efficiency and capacity of the alternative refrigerants could be expected to improve through design modifications that manufacturers would conduct before introducing a new product to market. However, given that the scope of this study covered only soft-optimized testing, no detailed assessment can be made of the extent of potential improvements through design changes. Within the bounds of what is possible in optimizing the units for soft-optimized tests, the ORNL test plan included only minor optimizations, including refrigerant charge, capillary tube length, and lubricant change. Therefore, these are conservative results that probably could be improved through further optimization. Additional optimization, including heat transfer circuiting and proper compressor sizing and selection, would likely yield better performance results for all of the alternative refrigerants.

Losses in cooling capacity are typically easier to recover through engineering optimization than are losses in COP. The primary practical limit to improvements in capacity is the physical size of the unit; but that is 
not expected to be a significant concern in this case, based on the magnitude of the capacity losses exhibited in this evaluation program. Thus, the COP losses and the increases in compressor discharge temperature are particularly important results of this testing program, in that these variables will be the primary focus of future optimization efforts.

This performance evaluation shows that viable replacements exist for both R-22 and R-410A at high ambient temperatures. Multiple alternatives for R-22 performed well. Many R-410A alternatives matched or exceeded the performance of R-410A. These low-GWP alternative refrigerants may be considered as prime candidate refrigerants for high ambient temperature applications. Before commercialization, engineering optimization carried out by manufacturers can address performance loss, the increase in compressor discharge temperature that many alternatives exhibited (particularly the R-410A alternatives), and any safety concerns associated with flammable alternatives. 


\section{INTRODUCTION}

Hydrofluorocarbon (HFC) refrigerants are non-ozone-depleting fluids that are used as working fluids in air-conditioning and refrigeration equipment as substitutes for ozone-depleting substances (ODS) that have been or are being phased out under the Montreal Protocol. However, some of the HFCs have high global warming potential (GWP), which introduces uncertainty about their use in the future because of their impact on the climate. HFCs currently account for only $1 \%$ of greenhouse gas emissions, but their use is growing rapidly, by as much as 10 to $15 \%$ per year, primarily because of their use as replacements for ODS and the increasing use of air conditioners globally. [3] Therefore, there is potential for significant reduction in greenhouse gas emissions through the substitution of high-GWP HFCs with lower-GWP alternatives.

While progress toward widespread application of low-GWP refrigerants continues, only limited information regarding the performance of the most commonly proposed low-GWP refrigerants is available. A particular concern is that low-GWP refrigerants might experience performance degradation at high-ambient-temperature conditions. To address this issue, the US Department of Energy (DOE), in cooperation with Oak Ridge National Laboratory (ORNL), established an evaluation program to assess the performance of several candidate low-GWP alternative refrigerants under high-ambient-temperature conditions. Carrier Corporation, international refrigerant suppliers, and technical experts from various countries also participated. The program evaluated the performance of mini-split air conditioners under high-ambient-temperature conditions using low-GWP refrigerants. The objective was to assess whether it is possible to achieve similar or better energy efficiency and cooling capacity with lower-GWP refrigerants compared with current baseline refrigerants R-22 and R-410A in mini-split air conditioners. This program was guided by an international expert panel consisting of members of government, academia, and industry from interested countries.

Other evaluation programs aimed at understanding the performance of low-GWP refrigerants at high ambient temperatures are currently under way. The United Nations Environment Programme (UNEP) and the United Nations Industrial Development Organization (UNIDO) are sponsoring two separate programs funded by the Multilateral Fund for the Implementation of the Montreal Protocol (MLF): Promoting LowGWP Refrigerants for Air-Conditioning Sectors in High-Ambient-Temperature Countries (PRAHA) and the Egyptian Program for Promoting Low-GWP Refrigerants’ Alternatives (EGYPRA). [4][5] PRAHA was developed in association with several high-ambient-temperature nations and is evaluating purposebuilt prototypes. EGYPRA, based in Egypt, is also testing purpose-built prototypes. Sections 3.2 and 3.3 of this report discuss PRAHA and EGYPRA, respectively, in more depth. In addition to those efforts, participants in the Air-Conditioning, Heating, and Refrigeration Institute's (AHRI) Low-GWP Alternative Refrigerants Evaluation Program (Low-GWP AREP) are conducting high-ambient-temperature testing with various types of heating, ventilating, and air-conditioning (HVAC) equipment. [6] Because of the different scope of each program (e.g., air-conditioning equipment versus general HVAC equipment, fulloptimization versus soft-optimization), the results from PRAHA, EGYPRA, Low-GWP AREP and the ORNL program are mostly independent, without overlap.

\subsection{PURPOSE/OBJECTIVES}

The objective of this program was to evaluate the performance and help determine the viability of several lower-GWP refrigerants as replacements for the baseline refrigerants (R-22 and R-410A) for mini-split air-conditioning units under high ambient temperatures. 


\subsection{SCOPE AND COVERAGE}

The program evaluated the performance of mini-split (ductless) air-conditioning units originally designed to use R-22 (an HCFC) or R-410A (a blend of two HFCs), both when using the baseline refrigerants and when using low-GWP alternatives. The primary objective of the evaluation was to determine whether it is possible, using the lower-GWP alternatives, to achieve comparable or better performance than with R-22 and R-410A. Ductless mini-split air conditioners were chosen as the equipment to be evaluated because they are the most common type of air conditioner used in residential and light commercial applications in most high-ambient-temperature regions.

The evaluation was performed at ORNL in Oak Ridge, Tennessee, USA, using a range of fluorinated and non-fluorinated low-GWP refrigerants, which are tested and compared with two baseline refrigerants: R-22 (an HCFC with GWP=1,760) and R-410A (a blend of two HFCs with GWP=1,924). ${ }^{*}$ There is currently a global effort to transition away from R-22, as agreed under the Montreal Protocol. Many nations are also transitioning away from R-410A because of its high GWP. These transitions are at various stages in different regions of the world, so including both refrigerants as baselines can provide a point of reference regardless of where particular countries stand in the transition process.

Testing of the baseline refrigerants was first carried out on the original equipment provided by the manufacturer. The units were then soft-optimized for use with the alternative refrigerants. Soft-optimized equipment can be modified with standard production-line components; that differentiates these tests from drop-in tests (in which only minor adjustments are allowed) and from purpose-built prototype testing (in which units are custom-designed to work with a specific alternative refrigerant). Drop-in tests are the simplest to conduct, and purpose-built prototypes are the most complex. Soft-optimization is considered an intermediate step. Purpose-built prototypes have the potential to achieve higher efficiency levels, but the process of designing and manufacturing them is more complex and time-consuming compared with soft-optimization and drop-in tests.

\subsection{PARTICIPANTS}

\subsubsection{Oak Ridge National Laboratory}

ORNL has been involved in the research and development (R\&D) of space-conditioning equipment and appliances for nearly 40 years. $^{\dagger}$ The Building Technologies Research and Integration Center (BTRIC) partnerships with industry have resulted in the successful introduction of products such as high-efficiency refrigerator-freezers, heat pump water heaters, high-efficiency supermarket refrigeration systems, and hybrid desiccant/vapor compression air-conditioning systems. ${ }^{\ddagger}$ Nine of these products have won the prestigious R\&D 100 Award.

The BTRIC User Facility at ORNL is the premier US DOE research facility devoted to the development of technologies that improve the energy efficiency and environmental compatibility of residential and commercial HVAC building equipment. BTRIC's mission is to identify, develop, and deploy energyefficient technologies by forming partnerships between DOE and industry for technology development and analysis, well-characterized laboratory and field experiments, and market outreach. The experimental facilities for building equipment research are ISO14001 certified for environmental compliance.

\footnotetext{
* Intergovernment Panel on Climate Change AR5 GWP values. See Section 4.2 for discussion of refrigerants and GWP values (and sources).

† ORNL's website includes detailed information on its history of work in space conditioning and appliances; available at http://web.ornl.gov/sci/buildings/.

${ }^{\ddagger}$ For more information on BTRIC, see the website at http://www.ornl.gov/user-facilities/btric.
} 
BTRIC is a leading center for the development of innovative air conditioners, heat pumps, water heaters, and appliances. The ORNL Heat Pump Design Model (HPDM) is one of the most frequently used heat pump models and is currently being used by several original equipment manufacturers (OEMs) in their sizing and selection software tools. ${ }^{* \dagger}$ Furthermore, ORNL has had an active role in the development in the United States of integrated heat pumps (air source and ground source) as well as heat-pump water heaters. [7][8]

BTRIC also has decades of experience in the research, design, and development of advanced heat exchangers. Its expertise in this area includes the measurement of heat transfer coefficients for zeotropic refrigerant mixtures and methods for improvement; evaluation of microchannel heat exchangers; and computational fluid dynamics (CFD) modeling to improve the performance of heat exchangers in HVAC equipment by reducing the maldistribution of air across the heat exchanger and of refrigerant inside the heat exchanger. In addition, ORNL has recently been involved in the application of rotary heat exchangers for refrigeration applications. ${ }^{\ddagger}$

Finally, BTRIC has decades of experience in alternative refrigerant evaluation programs. User facilities and flagship modeling capabilities were used during the chlorofluorocarbon (CFC) -to-HCFC transition and the HCFC-to-HFC transition, and are currently being leveraged as part of the transition from highGWP HFCs to lower-GWP refrigerants. This work has produced numerous publications in this field. Select examples include the following.

- $\quad$ CFC Phase-out - a strategy development project concerned with containing existing refrigerants and retrofitting or replacing CFC-based chillers with alternative refrigerants [9]

- Global Warming Impacts of Ozone-Safe Refrigerants and Refrigeration, Heating, and AirConditioning Technologies - an analysis of the contributions of various refrigerants in major applications to global warming [10]

- Development of Low Global Warming Potential Refrigerant Solutions for Commercial Refrigeration Systems Using a Life Cycle Climate Performance (LCCP) Design Tool_an LCCP analysis of the performance of typical commercial refrigeration systems with alternative refrigerants and minor system modifications [11]

- Energy and Global Warming Impacts of HFC Refrigerants and Emerging Technologies-a comparative analysis of the global warming impacts of alternative technologies using total equivalent warming impact [12]

\subsubsection{Industry}

As part of this program, major refrigerant producers such as Arkema, Chemours (formerly DuPont), Honeywell, and Mexichem provided sample prototype refrigerants with lower GWPs compared with existing refrigerants. They supplied ORNL with refrigerants that are being considered as alternatives to R-22 and R-410A at high-ambient-temperature conditions. Carrier, a US-based air conditioner manufacturer, donated equipment for testing, including both mini-split air-conditioning units specially designed for high-ambient-temperature conditions. One unit is designed for R-22 and the other for R-410A.

\footnotetext{
${ }^{*}$ For more information on ORNL's HPDM, see the website at: http://web.ornl.gov/ wlj/hpdm/MarkVII.shtml.

${ }^{\dagger}$ For a list of relevant reports on HPDM, see http://web.ornl.gov/ wlj/hpdm/Related_Reports.html.

${ }^{\ddagger}$ For a list of capabilities, see ORNL’s Experimental Capabilities and Apparatus Directory at http://web.ornl.gov/sci/buildings/docs/buildings_catalog.pdf.
} 


\subsubsection{International Expert Panel}

A group of HVAC experts was assembled to provide input and guidance to the evaluation program, including design of the program and review of the test results, the interim working paper, and the final report (for biographies of the panel members, refer to APPENDIX A). The investigators conducting the testing recognized that, given the international implications of the results of the evaluation program, it was essential that this panel consist of individuals from various nations, especially countries with hot climates. Accordingly, a number of governments were contacted to recommend experienced technical personnel who, whether from government, academia, or industry, would act independently, on their own behalf (i.e., not formally representing a government or an industrial entity) in providing guidance for this effort. In addition, representatives from UNEP and UNIDO were asked to join the panel, given the significant involvement of both these UN organizations in projects aimed at developing solutions for the replacements of HCFC and high-GWP HFC refrigerants in the air-conditioning sector. The panel met for the first time via teleconference on March 23, 2015; for a second time in a face-to-face meeting at the United Nations Conference Centre in Bangkok, Thailand, on April 19, 2015; for a third time via teleconference on June 30, 2015; and for a fourth time via a face-to-face meeting in Yokohama, Japan, on August 22, 2015.

\subsubsection{Mandate}

The panel was tasked with providing technical input for this study: Alternative Refrigerant Evaluation for High-Ambient-Temperature Environments: R-22 and R-410A Alternatives for Mini-Split Air

Conditioners. The technical input requested from the panel included recommending alternative refrigerants to be tested, commenting on appropriate test procedures, assessing results, and reviewing the interim working paper and the final report.

\section{SELECTION OF ALTERNATIVES AND TESTING CONDITIONS}

\subsection{ALTERNATIVE REFRIGERANTS SELECTION}

Guided by input from the expert panel, the investigators decided that the following criteria (in no particular order) should be considered when selecting alternative refrigerants for testing.

- Refrigerants shall have a lower GWP than the refrigerants being replaced. No strict upper limit on the GWP of alternative refrigerants was specified.

- Refrigerants shall be relatively close to commercial availability, or already commercially available (as determined by the expert panel).

- Refrigerants shall have properties that are a relatively close match to those of the baseline refrigerant that they are replacing. It is notable that temperature glide is an especially important property, in addition to capacity and coefficient of performance (COP). Further discussion of the temperature glide is provided in Sections 6.1 and 6.2.

- Refrigerants shall have information readily available about their characteristics.

In addition, it was decided that this program should include alternative refrigerants currently being evaluated by other high-ambient-temperature testing programs (e.g., Low-GWP AREP, PRAHA, and EGYPRA) and that flammability should not be one of the selection criteria. Nevertheless, the panel felt it important to include at least one alternative with A1 toxicity and flammability classification, provided other conditions were met. 
ASHRAE Standard 34 defines flammability and toxicity classes. The flammability classes are: 1, 2, 2L, and 3, where higher numbers indicate higher flammability. Class $2 \mathrm{~L}$ is a subgroup of mildly flammable class 2 refrigerants with a maximum burning velocity of $10 \mathrm{~cm} / \mathrm{sec}$. The toxicity classes are A and B, with A being nontoxic. As discussed in Section 4.2, this evaluation program used only refrigerants from classes A1, A2L, and A3. There is significant ongoing research and discussion on the safe use of flammable refrigerants, such as in the Japan Refrigeration and Air-Conditioning Industry Association (JRAIA) International Symposium on New Refrigerants and Environmental Technology 2014 (Kobe, 2014) and the 4th Symposium on Alternative Refrigerants for High-Ambient Countries (Dubai, 2014). ${ }^{*}+$

Given the uncertainties in LCCP models, the panel could not come to a consensus on whether to use LCCP as a selection criterion; it therefore recommended that LCCP not be used as a selection criterion. Although the concept of LCCP is generally accepted as a metric for evaluating alternative refrigerants, there is considerable disagreement about accurate LCCP values, largely because of uncertainties about refrigerant leakage rates.

\subsection{TESTING CONDITIONS}

Testing of all refrigerants was performed at each of the environmental conditions described in Table 1.

Table 1. Test conditions

\begin{tabular}{|l|l|l|c|c|c|}
\hline \multirow{2}{*}{ Test condition } & \multicolumn{1}{|c|}{ Outdoor $^{\boldsymbol{a}}$} & \multicolumn{4}{|c|}{ Indoor } \\
\cline { 2 - 6 } & $\begin{array}{c}\text { Dry-bulb } \\
\text { temperature }\end{array}$ & $\begin{array}{c}\text { Dry-bulb } \\
\text { temperature }\end{array}$ & $\begin{array}{c}\text { Wet-bulb } \\
\text { temperature }\end{array}$ & $\begin{array}{c}\text { Dew point } \\
\text { temperature }\end{array}$ & $\begin{array}{c}\text { Relative } \\
\text { humidity }\end{array}$ \\
\hline & \multicolumn{1}{c}{$\mathrm{C}\left({ }^{\circ} \mathrm{F}\right)$} & ${ }^{\circ} \mathrm{C}\left({ }^{\circ} \mathrm{F}\right)$ & ${ }^{\circ} \mathrm{C}\left({ }^{\circ} \mathrm{F}\right)$ & ${ }^{\circ} \mathrm{C}\left({ }^{\circ} \mathrm{F}\right)$ & $\%$ \\
\hline AHRI B $^{c}$ & $27.8(82)$ & $26.7(80.0)$ & $19.4(67)$ & $15.8(60.4)$ & 50.9 \\
AHRI A $^{c}$ & $35.0(95)$ & $26.7(80.0)$ & $19.4(67)$ & $15.8(60.4)$ & 50.9 \\
${\text { T3* }{ }^{d}}^{\text {T3 }^{c}}$ & $46(114.8)$ & $26.7(80.0)$ & $19(66.2)$ & $15.8(60.4)$ & 50.9 \\
Hot & $46(114.8)$ & $29(84.2)$ & $19(66.2)$ & $13.7(56.6)$ & 39 \\
Extreme & $52(125.6)$ & $29(84.2)$ & $19(66.2)$ & $13.7(56.6)$ & 39 \\
\hline
\end{tabular}

${ }^{a}$ There is no specification for the outdoor relative humidity as it has no impact on the performance.

${ }^{b}$ Dew-point temperature and relative humidity evaluated at $0.973 \mathrm{~atm}$ (14.3 psi)

${ }^{c}$ Per AHRI Standard 210/240

${ }^{d} \mathrm{~T} 3 *$ is a modified T3 condition in which the indoor settings are similar to the AHRI conditions.

\section{OTHER HIGH-AMBIENT-TEMPERATURE EVALUATION EFFORTS}

Three other high-ambient-temperature evaluation programs for alternative refrigerants are currently under way: Low-GWP AREP, PRAHA, and EGYPRA. For details, see the comparison of the programs in APPENDIX B.

\footnotetext{
* For details on the JRAIA International Symposium on New Refrigerants and Environmental Technology 2014, refer to http://www.jraia.or.jp/english/symposium/index.html.

${ }^{\dagger}$ For details on the $4^{t}$ h Symposium on Alternative Refrigerants for High-Ambient Countries, refer to http://4thhighambient.com/index.html.
} 


\subsection{LOW-GWP ALTERNATIVE REFRIGERANTS EVALUATION PROGRAM}

Low-GWP AREP is an industry-led effort on alternative refrigerants run by AHRI. Although Low-GWP AREP's focus is not high-ambient-temperature testing, the program is conducting testing at high-ambienttemperature conditions. ${ }^{*}$ The objective of Low-GWP AREP is to identify suitable alternatives to highGWP refrigerants. The intent of the program is to help industry select promising alternative refrigerants, understand the technical challenges involved in applying those refrigerants, and identify areas requiring further research that would lead to the use of these refrigerants. Ultimately, the objective is to identify potential replacements for the high-GWP refrigerants currently in use in the industry and present the performance of those replacements in a consistent manner. Low-GWP AREP is strongly supported by industry to assess the research needs, accelerate the industry response to environmental challenges raised by the use of high-GWP refrigerants, and avoid duplicative precompetitive work by individual equipment manufacturers. To achieve these goals, the program has tested a broad spectrum of equipment, including air conditioners, heat pumps, dehumidifiers, chillers, water heaters, ice makers, and refrigeration equipment and has published 46 test reports and a literature review to date.

Low-GWP AREP has carried out compressor calorimeter tests, equipment drop-in tests, and softoptimized equipment tests. Drop-in tests allow for only minor adjustments to the equipment being tested so that it may be used with the alternative refrigerant instead of the baseline refrigerant for which it was designed. Soft-optimized equipment can be modified using standard production-line components, provided that the changes are indicated in the report; furthermore, the overall heat exchanger area must remain constant, but the area ratio between the condenser and the evaporator may be optimized. ${ }^{\dagger}$ Compressor calorimeter tests were performed according to the conditions set forth in ASHRAE 23. AREP tests have not included mini-split air conditioners.

The Low-GWP AREP test matrix is summarized in Table B.3 and Table B.4 in APPENDIX B.

\subsection{PROMOTING LOW-GWP REFRIGERANTS FOR THE AIR-CONDITIONING SECTORS IN HIGH-AMBIENT-TEMPERATURE COUNTRIES (PRAHA)}

PRAHA is a regional project approved by the Executive Committee of the Multilateral Fund and under implementation by UNEP and UNIDO. [5] The primary objective of the project is to investigate sustainable refrigerant technologies for high-ambient-temperature countries. The project also aims to support technical and policy decisions, share information about demonstration projects, encourage the development of regional standards, and link regional energy efficiency to the adoption of a long-term low-GWP alternative.

The project includes three components: building and testing of prototypes, study of long-term feasible technologies, and coordination of the phase-out requirements with Minimum Energy Performance Standards programs. Seven local manufacturers from Saudi Arabia, Bahrain, Kuwait, and the United Arab Emirates are participating in these efforts, as well as six international technology providers. Furthermore, PRAHA and AREP have created a joint declaration for the promotion of low-GWP alternatives and the exchange of relevant technical information. [5]

PRAHA is investigating a total of six refrigerants. Two are HFC/hydrofluoro olefin (HFO) blends meant to replace R-22, and two others are HFC/HFO blends designed to replace R-410A. R-32, an HFC, and R-290, commonly known as propane, are also being tested. The refrigerants are tested according to the

\footnotetext{
* For details, refer to http://www.ahrinet.org/site/514/Resources/Research/AHRI-Low-GWP-Alternative-Refrigerants-Evaluation.

${ }^{\dagger}$ Optimization of heat exchanger area ratios was not performed for the ORNL evaluation program tests reported in this study.
} 
conditions in ISO 5151. A 2 hour continuity test at $52^{\circ} \mathrm{C}$ is also performed. The products being tested are window room air conditioners, decorative split systems, ducted split systems, and packaged units. Each unit is a prototype specifically designed for a given refrigerant and capacity.

The PRAHA test matrix is summarized in Table B.2 in APPENDIX B.

\subsection{EGYPTIAN PROGRAM FOR PROMOTING LOW-GWP REFRIGERANTS' ALTERNATIVES (EGYPRA)}

EGYPRA is a national project introduced as an enabling activity for the air-conditioning industry under the Egyptian HCFC Phase-out Management Plan, which in turn was approved by the Executive Committee of the MLF; the project is under implementation by UNEP and UNIDO. [4] The project is focused on Egypt. Its objective is to test purpose-built ductless mini-split and central ducted airconditioning prototypes using new refrigerants and compare their performance with that of R-22 and R-410A baseline units. Testing will include mini-splits with capacities of $3.5 \mathrm{~kW}_{\text {th }}$ (1 refrigeration ton, or TR), $5.25 \mathrm{~kW}_{\text {th }}(1.5 \mathrm{TR})$, and $7 \mathrm{~kW}_{\text {th }}$ (2 TR); and a $35 \mathrm{~kW}_{\text {th }}$ (10 TR) central air-conditioning system with both common heat exchangers and microchannel heat exchangers.

EGYPRA is investigating a total of eight refrigerants - three HFC/HFO blends meant to replace R-22 and three HFC/HFO blends meant to replace R-410A, as well as R-32 and R-290. Testing is done in accordance with EOS (Egyptian Organization for Standardization and Quality) 4814 and EOS 3795 (ISO 5151) and will include data collection at T1 (outdoor temperature: $35^{\circ} \mathrm{C}$, indoor temperature: $27^{\circ} \mathrm{C}$ ) and T3 temperature conditions (refer to Table 1 for T3 conditions). Thirty-six prototypes are being built with dedicated compressors for each refrigerant. The project participants are currently building prototypes, and results are expected to be available early in 2016. [4]

\subsection{COMPARISON OF HIGH-AMBIENT-TEMPERATURE TESTING PROGRAMS}

The results from PRAHA and EGYPRA will complement the results of the ORNL performance evaluation program because they are based on prototypes, whereas the ORNL program evaluated softoptimized production units. Additionally, the ORNL program included refrigerants that are not considered in PRAHA or EGYPRA, further complementing the results from these programs. These programs also use multiple equipment types. Whereas the ORNL evaluation program was focused on ductless minisplits, EGYPRA also includes central air-conditioning units (including one unit with microchannel heat exchangers), and PRAHA includes window units, ducted units, and packaged units.

Low-GWP AREP also offers some results that complement the results from PRAHA, EGYPRA, and the ORNL evaluation program. However, many of the Low-GWP AREP tests did not cover high-ambienttemperature conditions on similar equipment (no tests for mini-split air conditioners) and are therefore not directly applicable. Nevertheless, a number of test reports that have already been published included highambient-temperature testing, and more are expected in Phase II of Low-GWP AREP.

\section{EXPERIMENTAL FACILITIES AND EQUIPMENT}

\subsection{MINI-SPLIT AIR-CONDITIONING UNITS}

ORNL performed drop-in tests for two baseline mini-split systems: a $5.25 \mathrm{~kW}_{\text {th }}(1.5 \mathrm{TR}) \mathrm{R}-22$ system and a $5.25 \mathrm{~kW}_{\text {th }}(1.5 \mathrm{TR}) \mathrm{R}-410 \mathrm{~A}$ system. The R-22 unit is from the product family Eco Plus, model number 42KHRT18-308. The corresponding condensing unit is 38MKR18US30-03. The R-410A unit is from the product family Xpression Elite, model number 42KHL0183P. The corresponding condensing unit is 
38KHL0183. Appendix C provides details and photos of the experimental setup. Figure 1 shows the two baseline units provided by Carrier.

\section{- Carrier has donated two split condensing units $(60 \mathrm{~Hz})$}
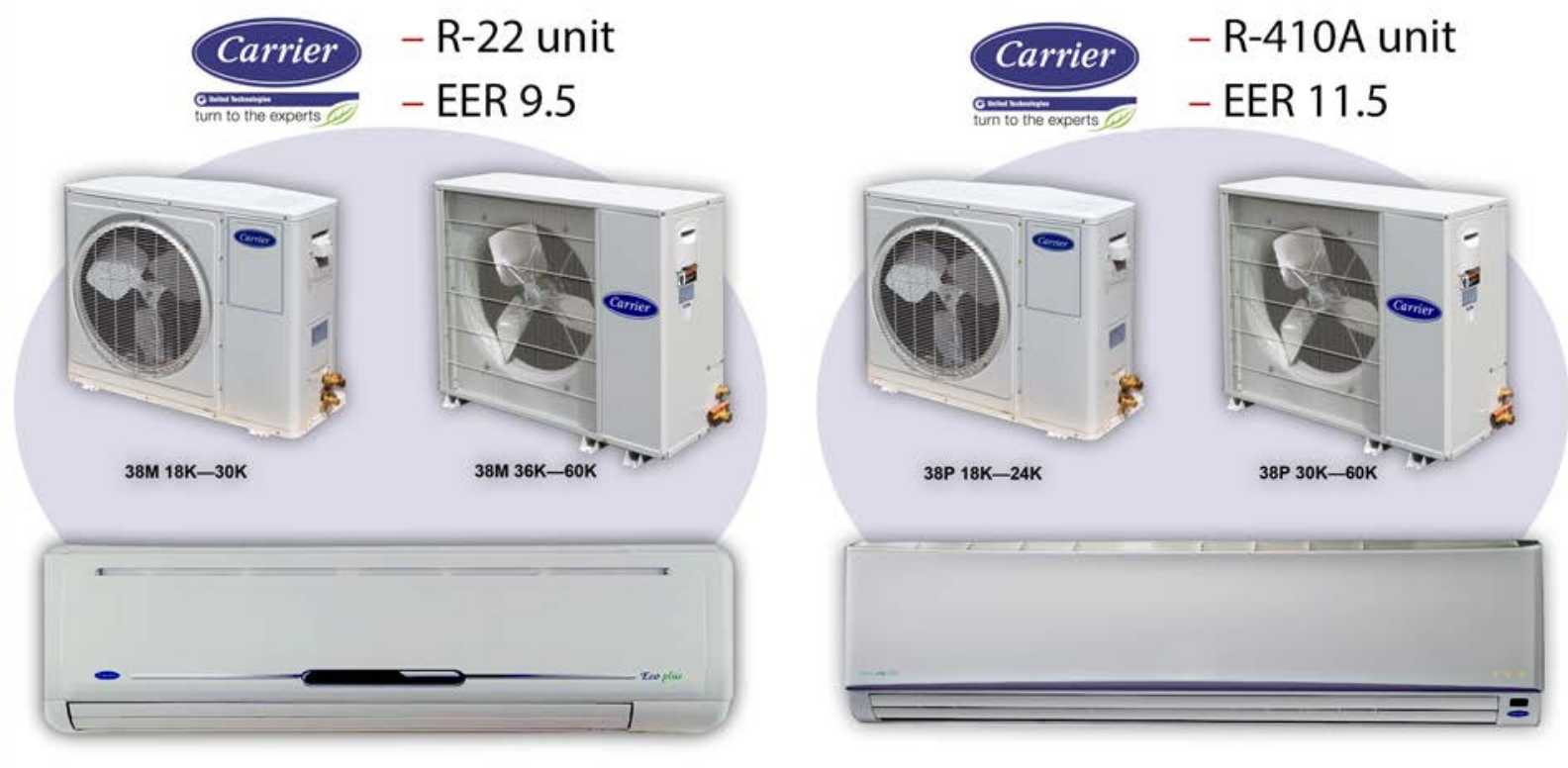

Figure 1. Baseline equipment provided by Carrier designed for high-ambient-temperature conditions.

Owing to the differences in design and in baseline efficiency, it is not possible to compare the test results for the R-22 unit and the R-410A unit directly. Thus, the results in Sections 6.1 and 6.2 are not directly comparable. For a more accurate comparison of the relative performance degradation of each refrigerant with temperature, see Figures D.3, D.4, E.3, and E.4 in Appendices D and E, respectively.

\subsection{ALTERNATIVE REFRIGERANTS}

\subsubsection{Alternative Refrigerants for the R-22 Unit}

The panel selected five alternative refrigerants for testing in the R-22 unit. In addition, ORNL's evaluation schedule allowed for time to test DR-93, a refrigerant with a higher GWP than the five alternatives but with an A1 toxicity and flammability classification. Including DR-93 brought the number of alternatives with A1 classifications to 2. Table 2 shows the details for each of the five alternative refrigerants, the baseline (R-22), and DR-93. ${ }^{*}$ The refrigerant manufacturers provided the data to ORNL via NIST REFPROP files. All of the selected alternatives are ASHRAE Standard 34 safety class A refrigerants, meaning they are of low toxicity. For flammability, the alternatives include ASHRAE safety classes 1, 2L, and 3, for which higher numbers indicate higher flammability.

\footnotetext{
* For thermodynamic cycle calculations for each alternative refrigerant compared with R-22, refer to the Low-GWP AREP Participants' Handbook (April 17, 2015) by the Air-Conditioning, Heating and Refrigeration Institute, pages 70 (R-290), 86 (ARM-20B), 89 (DR-3), 90 (L-20A and DR-93) and 91 (N-20B). Available at http://www.ahrinet.org/App_Content/ahri/files/RESEARCH/Participants_Handbook2015-04-17.pdf
} 
The charge size was determined during the soft-optimization process. See Section 5 for an additional discussion of the process.

The expert panel did not recommend a priority order for conducting these tests. The panel strongly recommended, however, that the baseline refrigerant (R-22) be tested again upon completion of all the alternatives to ensure that the unit's operating conditions remained unchanged.

The R-22 unit was tested both with mineral oil (ATMOS M60 [A]), the OEM-specified lubricant for use with R-22, and with POE oil (ISO 68), the lubricant used for the alternative refrigerants. The expert panel's consensus recommendation was that R-22 with mineral oil be the baseline since that is how the unit was designed and shipped by the manufacturer. (See APPENDIX D for results for R-22 with POE oil.)

Table 2. Baseline and alternative refrigerant data for the $\mathrm{R}-22$ unit

\begin{tabular}{|r|c|c|c|c|}
\hline Refrigerant & Manufacturer & $\begin{array}{c}\text { ASHRAE } \\
\text { safety class }\end{array}$ & $\mathbf{G W P}_{\mathbf{A R} \mathbf{4}}{ }^{\boldsymbol{a}}$ & $\mathbf{G W P}_{\mathrm{AR} 5}{ }^{\boldsymbol{a}}$ \\
\hline R-22 (baseline) & - & A1 & 1,810 & 1,760 \\
\hline N-20B & Honeywell & A1 & 988 & 904 \\
DR-3 & Chemours & A2L & 148 & 146 \\
ARM-20B & Arkema & A2L & 251 & 251 \\
L-20A (R-444B) & Honeywell & A2L & 295 & 295 \\
R-290 & - & A3 & 3 & 3 \\
DR-93 & Chemours & A1 & 1,258 & 1,153 \\
\hline
\end{tabular}

${ }^{a}$ Evaluated as weighted average values of the GWP of the refrigerant blend components provided by the refrigerant manufacturers and the reported GWP values of those components in IPCC AR4, 2007 [1] and IPCC AR5, 2013 [2] respectively.

\subsubsection{Alternative Refrigerants for the R-410A Unit}

Table 3 shows the five R-410A alternatives selected by the panel for evaluation. ${ }^{*}$ All these selected alternatives for this unit are ASHRAE safety class A2L (nontoxic, mildly flammable, low burning velocity).

Table 3. Baseline and alternative refrigerant data for the R-410A unit

\begin{tabular}{|r|c|c|c|c|}
\hline \multicolumn{1}{|c|}{ Refrigerant } & Manufacturer & $\begin{array}{c}\text { ASHRAE } \\
\text { safety class }\end{array}$ & $\mathbf{G W P}_{\mathbf{A R} \mathbf{4}}{ }^{\boldsymbol{a}}$ & $\mathbf{G W P}_{\text {AR5 }} \boldsymbol{}$ \\
\hline R-410A (baseline) & - & A1 & 2088 & 1924 \\
\hline R-32 & Daikin & A2L & 675 & 677 \\
DR-55 & Chemours & A2L & 698 & 676 \\
L-41 (R-447A) & Honeywell & A2L & 583 & 572 \\
ARM-71A & Arkema & A2L & 460 & 461 \\
HPR-2A & Mexichem & A2L & 600 & 593 \\
\hline
\end{tabular}

${ }^{a}$ Evaluated as weighted average values of the GWP of the refrigerant blend components provided by the refrigerant manufacturers and the reported GWP values of those components in IPCC AR4, 2007 [1] and IPCC AR5, 2013 [2] respectively.

The amount of refrigerant charge is based upon the value determined during the soft-optimization process. See Section 5 for additional discussion of the process.

\footnotetext{
* For thermodynamic cycle calculations for each alternative refrigerant compared to R-410A, refer to the Low-GWP AREP Participants' Handbook (April 17, 2015) by the Air-Conditioning, Heating and Refrigeration Institute, pages 56 (R-32), 83 (ARM-71A), 84 (DR-55), 85 (L-41) and 86 (HPR-2A). Available: http://www.ahrinet.org/App_Content/ahri/files/RESEARCH/Participants_Handbook2015-04-17.pdf
} 
The expert panel did not recommend a priority order for conducting these tests. The panel strongly recommended, however, that the baseline refrigerant (R-410A) be tested again upon completion of all alternatives, in order to ensure that the unit's operating conditions remain unchanged.

\subsection{EXPERIMENTAL FACILITIES}

The ORNL Multi-Zone Environmental Chambers, shown in Figure 2, were used for this project. This facility characterizes the performance of multi-zone electric or gas HVAC systems for residential and light commercial use. The "outdoor" chamber is $6.1 \times 4.6 \mathrm{~m}(20 \times 15 \mathrm{ft})$; the $8.5 \mathrm{~m}(28 \mathrm{ft})$ square "indoor" chamber can be divided into up to four spaces controlled at different conditions to represent separate zones. Dry-bulb temperature can be controlled at -23 to $55^{\circ} \mathrm{C}\left(-10\right.$ to $\left.131^{\circ} \mathrm{F}\right)$ and relative humidity at 30 to $90 \%$. Utilities include $480 \mathrm{~V}$, three-phase power at 225 A with step-down to 240, 208, and $120 \mathrm{~V}$. In this project, the indoor side was split into two chambers, each $8.5 \times 4.25 \mathrm{~m}$ so that two systems could be evaluated in parallel. The chambers are equipped with two code testers-one that can supply and measure airflow at up to $5100 \mathrm{~m}^{3} / \mathrm{h}(3000 \mathrm{cfm})$ and the other at up to $11,900 \mathrm{~m}^{3} / \mathrm{h}(7000 \mathrm{cfm})$. The code testers have the required duct mixers and temperature sampling trees.

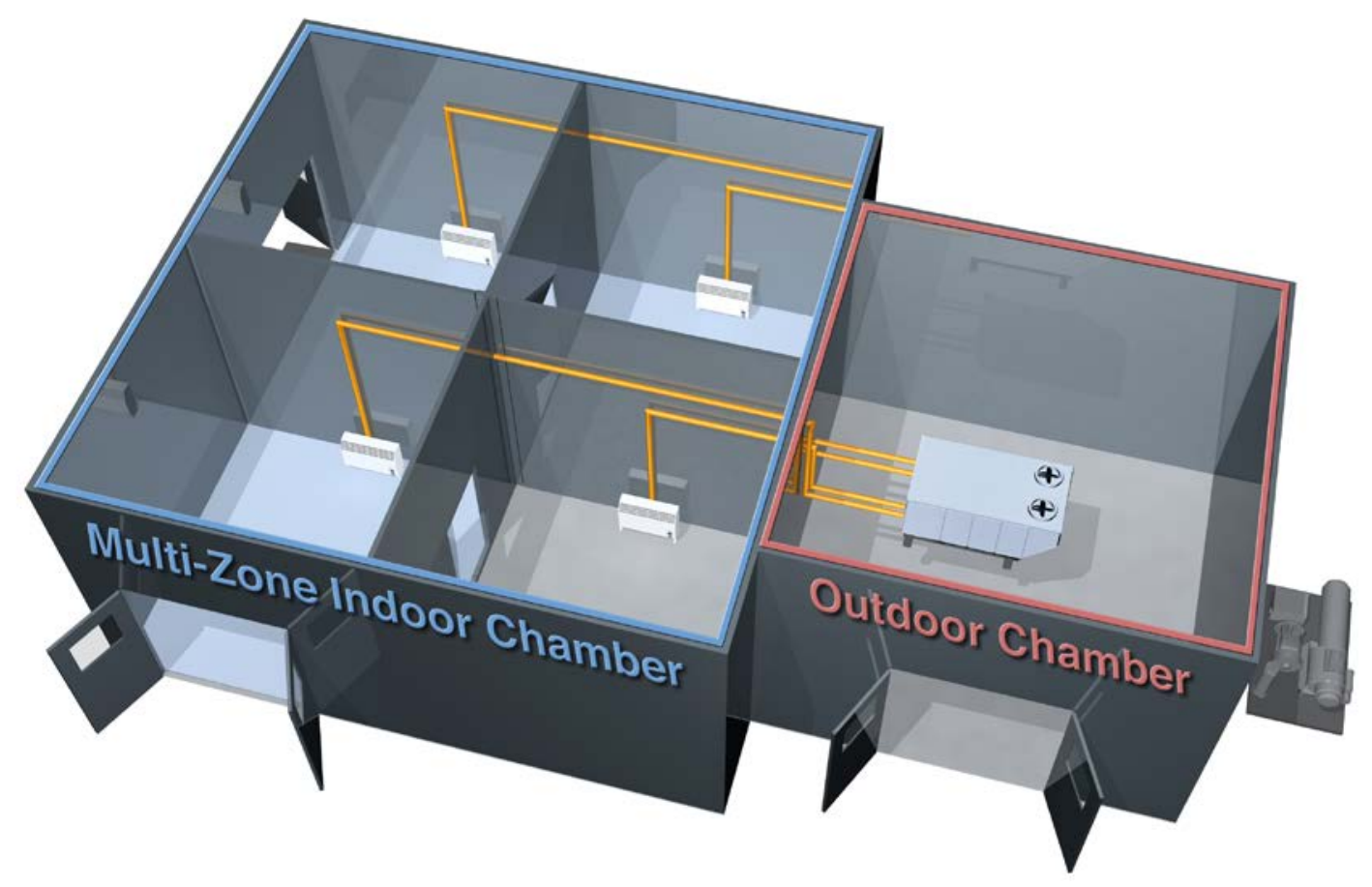

Figure 2. Multi-zone environmental chambers at ORNL BTRIC.

\subsection{EXPERIMENTAL SETUP AND INSTRUMENTATION}

A comprehensive experimental facility was designed and built to comply with ANSI/AHRI Standard 210/240 and ANSI/ASHRAE Standard 37. The air enthalpy method was used to evaluate the performance of the indoor unit, and the refrigerant enthalpy method was used as a secondary means of evaluating the system performance to establish energy balance and assess measurement accuracy. For an overview of the experiment test setup, refer to APPENDIX C.

Table C.1 in APPENDIX C summarizes the instrumentation used for testing. All of the instrumentation provides higher accuracy than is required by ASHRAE Standard 37 (Table 2b). The data are collected to 
satisfy Table 3 of the ASHRAE Standard 37 for both the indoor air enthalpy method column and the refrigerant enthalpy method column. Additional data were recorded to increase the level of understanding of the alternative refrigerants, including compressor shell temperature and readings from additional surface thermocouples on the liquid line and the compressor suction line.

\subsection{ALTERNATIVE REFRIGERANT EVALUATION EXPERIMENTAL DESIGN}

ORNL evaluated the R-22 unit with five alternative refrigerants. ORNL also evaluated the R-410A unit with five alternative refrigerants. For each alternative refrigerant, ORNL evaluated the performance at six test conditions each, for a total of 60 tests with alternative refrigerants. Additionally, each unit was tested with its baseline refrigerant 12 times (6 times before and 6 times after testing the alternative refrigerants). Consequently, the total number of tests was 84 . Table 4 summarizes the test plan.

Table 4. ORNL test plan summary

\begin{tabular}{|c|c|c|c|c|c|c|c|c|c|c|c|c|c|}
\hline & 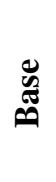 & $\begin{array}{l}\text { 菊 } \\
\text { ż }\end{array}$ & $\begin{array}{l}\stackrel{m}{\alpha} \\
\stackrel{\mu}{a}\end{array}$ & 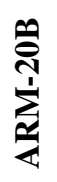 & 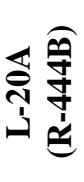 & 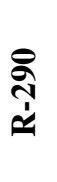 & 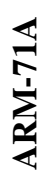 & $\begin{array}{l}\tilde{\widetilde{d}} \\
\stackrel{\alpha}{\varkappa}\end{array}$ & 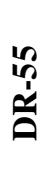 & 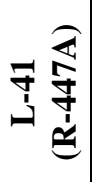 & 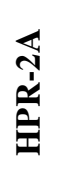 & 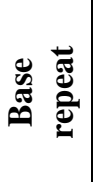 & $\begin{array}{c}\text { Total } \\
\text { \# of } \\
\text { tests }\end{array}$ \\
\hline R-22 unit & $x$ & $x$ & $x$ & $x$ & $x$ & $x$ & & & & & & $x$ & 42 \\
\hline R-410A unit & $\times$ & & & & & & $\times$ & $x$ & $\times$ & $x$ & $\times$ & $x$ & 42 \\
\hline
\end{tabular}

ORNL performed selected additional tests that were not initially planned. The following additional tests were performed with the R-22 unit:

- DR-93 using POE oil as an additional alternative lubricant, which ORNL added to the test plan as a secondary priority for testing only where the schedule allowed.

- $\quad$ R-22 using POE oil as a lubricant to allow for comparison against R-22 using mineral oil as a lubricant and against other alternatives using POE oil.

- R-290 using mineral oil as a lubricant and original capillary tube to allow for a true drop-in comparison between R-22 and R-290. It also allowed for comparison against R-290 using POE oil as a lubricant and against R-22 using mineral oil.

- R-290, R-444B, and ARM-20B using the original capillary tube and POE as a lubricant.

The following additional tests were performed with the R-410A unit:

- L-41 (R-447A), HPR-2A, ARM-71A, DR-55, and R-32 using the original capillary tube and POE as a lubricant.

Table 5 shows a summary of the additional tests and the section of the report where their results are presented. Considering the tests in Table 4 and Table 5, the total number of tests performed by ORNL was 126. 
Table 5. Additional tests conducted (not included in original schedule)

\begin{tabular}{|c|c|c|c|}
\hline Purpose of test & Refrigerant & $\begin{array}{c}\text { Number } \\
\text { of tests }\end{array}$ & Results \\
\hline Additional refrigerant & DR-93 & 6 & Section 6.1 \\
Original capillary tube & R-290 & 3 & APPENDIX D \\
Original capillary tube & L-20A (R-444B) & 3 & APPENDIX D \\
Original capillary tube & ARM-20B & 3 & APPENDIX D \\
Original capillary tube & L-41 (R-447A) & 3 & APPENDIX E \\
Original capillary tube & HPR-2A & 3 & APPENDIX E \\
Original capillary tube & ARM-71A & 3 & APPENDIX E \\
Original capillary tube & DR-55 & 3 & APPENDIX E \\
Original capillary tube & R-32 & 3 & APPENDIX E \\
Different lubricant & R-22 (POE) & 6 & APPENDIX D \\
Different lubricant & R-290 (mineral oil) & 6 & APPENDIX D \\
\hline
\end{tabular}

\section{EXPERIMENTAL PROCEDURE}

\subsection{OVERALL PROCEDURE}

ORNL followed ANSI/ASHRAE Standard 37 to test two mini-split $5 \mathrm{~kW}_{\text {th }}(1.5 \mathrm{TR})$ air-conditioning systems designed for high-ambient-temperature conditions. The first unit was an R-22 unit, and the second unit was designed for R-410A. The indoor side of the multi-zone environmental chambers was divided into two chambers. Each indoor chamber housed the indoor unit of the corresponding mini-split system connected with the associated air-enthalpy tunnel, and both outdoor units were installed in the outdoor chamber. The following steps were taken to evaluate the equipment and refrigerant combinations.

1. Perform charge optimization at the AHRI A conditions. ${ }^{*}$ See Section 5.2.

2. At the optimum charge, evaluate the performance at T3 conditions (see Table 1 for T3 conditions). If adequate subcooling and superheat are available, proceed with testing. Otherwise, adjust the charge to ensure $100 \%$ liquid entering the capillary tube, based on the mass flow meter measurement, and avoid evaporator flooding.

3. Run the test matrix (each refrigerant at each test condition) as summarized in Table 4. Collect steady-state data for 30 minutes at each condition. ${ }^{\dagger}$

4. To ensure system performance is maintained over the test period, retest the unit with the baseline refrigerant to verify the system performance stability after finishing all alternative refrigerant tests.

The baseline units were modified slightly to allow for adequate instrumentation. First, the liquid line was diverted outside the outdoor unit housing to allow installation of the Elite Coriolis mass flow meter (CMF025), which was used for the energy balance, as shown in Section 6.3.2. A capillary tube header was also placed after the Coriolis mass flow meter to facilitate testing of up to five capillary tubes.

\footnotetext{
${ }^{*}$ ORNL performed charge optimization at AHRI A conditions $\left(35^{\circ} \mathrm{C}\left[95^{\circ} \mathrm{F}\right]\right.$ outdoor and $26.7^{\circ} \mathrm{C}\left[80.0^{\circ} \mathrm{F}\right]$ indoor $)$ because it is the closest of the test conditions in this study to manufacturers' reported rating conditions (ISO T1 conditions $-35^{\circ} \mathrm{C}$ [ $95^{\circ} \mathrm{F}$ ] outdoor and $27^{\circ} \mathrm{C}\left[80.6^{\circ} \mathrm{F}\right]$ indoor). It is assumed that this is therefore also the condition for which manufacturers do their system design and analysis.

${ }^{\dagger}$ Steady state is established when the average dry-bulb temperatures at the inlet of the indoor and outdoor heat exchangers are within $0.28^{\circ} \mathrm{C}\left(0.5^{\circ} \mathrm{F}\right)$ of the desired conditions, and the individual readings of each instrument at the inlet and outlet of each heat exchanger are within $0.56^{\circ} \mathrm{C}\left(1.0^{\circ} \mathrm{F}\right)$ of the average values of these quantities. Furthermore, the average wet-bulb temperature at the inlet of the indoor heat exchanger must be within $0.17^{\circ} \mathrm{C}\left(0.3^{\circ} \mathrm{F}\right)$ of the desired conditions and the individual readings within $0.56^{\circ} \mathrm{C}\left(1.0^{\circ} \mathrm{F}\right)$ of the average value, and the airflow rate must be within $1 \%$ of the desired value.
} 
Finally, pressure and in-stream thermocouples (for the R-22 unit) or in-stream resistance temperature detectors (for the R-410A unit) were used to evaluate the refrigerant enthalpy at the liquid line just before the capillary tube and before and after the evaporator. The capillary tube header was used to select appropriate capillary tubes for the alternative refrigerants. See Figure 3 for a high-level schematic diagram of the system and APPENDIX C for more details.

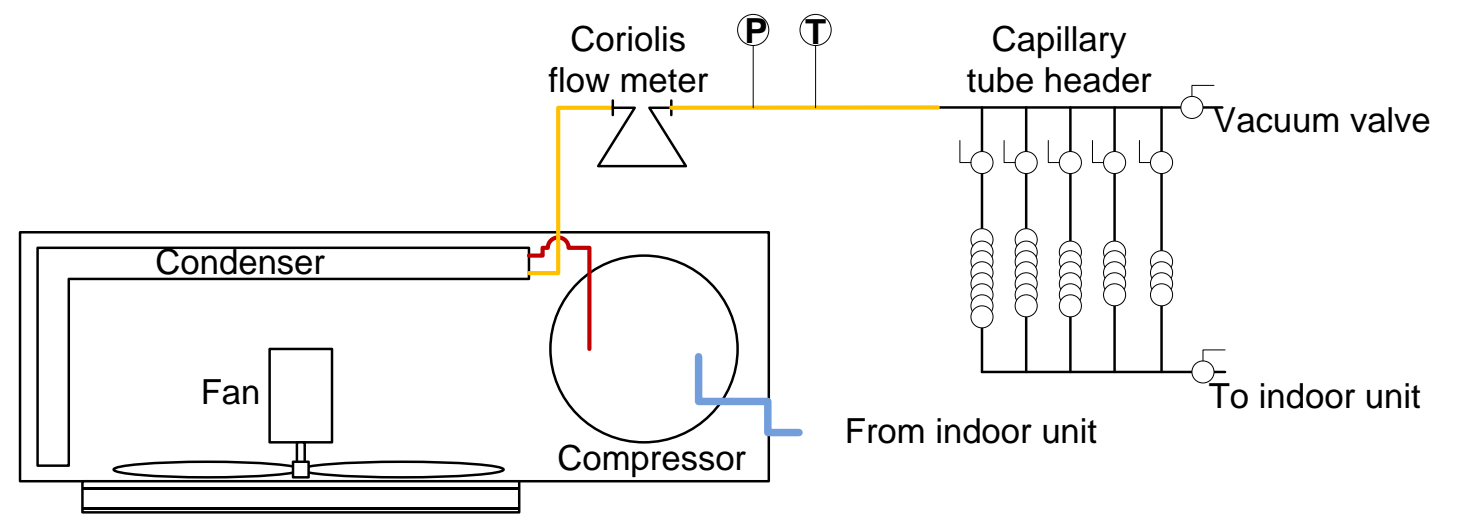

Figure 3. Outdoor unit configuration.

\subsection{PROCESS FOR SOFT-OPTIMIZATION}

ORNL's soft-optimization process consisted primarily of adjusting the capillary tube to control flow to the evaporator in the indoor unit and performing charge-mass optimization. Both parameters were modified to maximize the system COP at the AHRI A condition. The AHRI A condition was chosen as it is the closest condition tested to the ISO T1 test used by the manufacturer to rate the unit. The baseline capillary tube had an inner diameter (ID) of $2.00 \mathrm{~mm}$ (0.079 in.), an outer diameter (OD) of $3.2 \mathrm{~mm}$ (1/8 in.), and a length of $508 \mathrm{~mm}$ (20 in.). Unfortunately, at the time of testing, ORNL was only able to obtain capillary tubes with an ID of $1.65 \mathrm{~mm}(0.065 \mathrm{in}$.). Therefore, ORNL first identified the appropriate alternative capillary tube length to be $254 \mathrm{~mm}$ (10 in.). The same capillary tube spool with ID of $1.65 \mathrm{~mm}$ (0.065 in.) was used for the soft-optimization and selection of the appropriate flow restriction. The processes for capillary tube length optimization and charge optimization are as follows (see Table 6 for nomenclature).

1. Size capillary tubes using appropriate correlation and fabricate $( \pm 50.8 \mathrm{~mm}[2 \mathrm{in}],. \pm 25.4 \mathrm{~mm}$ [1 in]., and exact size per calculations). [13]

2. Charge the system with $\mathbf{M}_{\text {opt,ref\# }}=\mathbf{M}_{\text {baseline,ref\# }} *\left(\rho_{\text {reff, liq }} / \rho_{\mathrm{R}-22 l i q}\right)$ as a starting point.

3. Run charge optimization campaign at the AHRI A condition: collect steady-state data for 10 minutes as follows:

a. $\mathrm{M}_{\text {opt,ref\# }}$ and exact capillary tube length

b. $\quad M_{\text {opt,ref\# }}$ and $25.4 \mathrm{~mm}$ (1 in.) shorter capillary tube length; if higher COP is achieved, proceed to (c); otherwise, proceed to (d).

c. $\mathrm{M}_{\text {opt,ref\# }}$ and $50.8 \mathrm{~mm}$ (2 in.) shorter capillary tube length, skip to (f).

d. $\quad M_{\text {opt,ref\# }}$ and $25.4 \mathrm{~mm}$ ( 1 in.) longer capillary tube length; if higher COP is achieved, proceed to (e); otherwise, proceed to (f).

e. $\quad \mathrm{M}_{\text {opt,ref\# }}$ and $50.8 \mathrm{~mm}$ (2 in.) longer capillary tube length.

f. Add/subtract ${ }^{*}$ refrigerant charge (approximately $2 \mathrm{oz}$ at a time), go back to (a).

\footnotetext{
* Refrigerant is added to and removed from the unit as liquid (as indicated by the mass flow meter) to avoid fractionation.
} 
4. Run the unit with $\mathrm{M}_{\mathrm{opt} \text {,reft }}$ and the selected capillary tube at T3 conditions to ensure adequate subcooling and superheating. If they are adequate, proceed to the next step; if not, adjust the

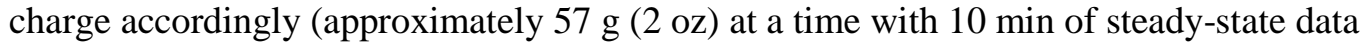
collected) and then proceed to the next step.

5. Evaluate the system performance for all test conditions listed in Table 1.

Table 6. Test process nomenclature, subscripts and symbols

\begin{tabular}{|l|l|}
\hline \multicolumn{1}{|c|}{ Symbol } & \multicolumn{1}{c|}{ Meaning } \\
\hline $\mathrm{M}$ & Refrigerant charge \\
$\mathrm{Opt}$ & Optimized \\
ref\# & Alternative refrigerant \\
$\mathrm{Liq}$ & Liquid \\
$\mathrm{R}-22$ & Refrigerant \\
$P$ & Density \\
\hline
\end{tabular}

Soft-optimization, as defined by Low-GWP AREP, allows for minor refinements of the system being tested with a particular alternative refrigerant, provided commonly available components are used. Examples of potential changes, according to AHRI, include

... compressor displacement and/or motor size; flow control; heat transfer circuiting; use of a liquid-line/suction-line heat exchanger; amount of refrigerant charge; use of a variable speed compressor motor; diameter/size of the tubing to adapt to the refrigerant volume flow and pressure drop; size of accumulators; and lubricant. In addition, the heat transfer area of the soft-optimized system's evaporator and condenser may be changed, provided that the sum total area remains the same as the baseline system. [14]

With fewer modifications, the testing may be considered drop-in, which can include "only minor modifications, if any" and may include optimization of refrigerant charge quantity, adjustment of expansion device (if adjustable), and adjustment of compressor speed. [15]

As part of the ORNL evaluation program, the lubricants were changed, charges optimized, and capillary tube/flow control changes implemented. These changes, in particular the capillary tube optimization, characterize soft-optimization as opposed to drop-in testing. Additional changes, still within the scope of soft-optimization, could be made for future testing, with the potential to increase performance.

\subsection{PROCESS FOR CHANGING REFRIGERANTS AND THE LUBRICANTS}

The following steps were followed to change refrigerants between sets of tests.

1. The refrigerant was reclaimed in empty cylinders.

2. The system was put under vacuum for an extended period of time (minimum of $3 \mathrm{~h}$ ) to ensure all the refrigerant was dissolved from the oil.

3. The refrigerant was slowly charged from the liquid port through the refrigerant suction line.

In the case of the R-22 unit, further modifications were required after baseline testing and before initiating testing of the alternative refrigerants.

1. Replace mineral oil with POE oil.

2. Replace capillary tube with a capillary tube tree consisting of five lengths (exact length, $\pm 25.4 \mathrm{~mm}$ [1 in.] of the exact length, and $\pm 50.8 \mathrm{~mm}$ [2 in.] of the exact length).

3. Adjust the refrigerant charge: $\mathrm{M}_{\mathrm{opt}}=\mathrm{M}_{\mathrm{opt}, \mathrm{R}-22}+\rho_{\mathrm{R}-22 \mathrm{liq}} * \mathrm{~V}_{\text {cap-tube header }}$. 
4. Run test at AHRI A conditions with similar capillary tube; compare performance with baseline performance (if COP and capacity are within $\pm 5 \%$, skip to \#7).

5. Compare the performance with that of the other capillary tubes (shorter and longer).

6. Use the capillary tube that provides the closest performance to that of the baseline refrigerant and run charge optimization.

7. Run test at T3 conditions.

8. Drain oil (POE + traces of mineral oil).

9. Charge with fresh POE oil.

10. Evacuate system for at least $3 \mathrm{~h}$ and proceed with the alternative refrigerant evaluation.

\section{RESULTS AND DISCUSSION}

\subsection{RESULTS FOR THE R-22 UNIT}

This section describes the air-side performance results for R-22 and its alternatives at all test conditions (AHRI A and B, ISO T3, T3*, Hot, and Extreme, as defined in Table 1) and then presents the results for the AHRI A, ISO T3, Hot, and Extreme test conditions in more detail to show performance trends as ambient temperature changes. The results for the three alternative refrigerants generally showing the best performance are presented in greater detail.

The six alternative refrigerants (as discussed in Section 4.2) are: N-20B, DR-3, ARM-20B, L-20A (R-444B), DR-93, and R-290. All use POE oil as a lubricant. As discussed in Section 4.2.1, the expert panel recommended using R-22 with mineral oil as the baseline; all results in this section reflect this decision.

Some of the refrigerant mixtures may result in high temperature glide (difference in saturation vapor and saturation liquid temperatures at a given saturation pressure). This would result in unfavorable performance, since condensation and evaporation would no longer be a constant temperature process. For the present report, the evaporator glide was calculated as the difference between the evaporator outlet saturation temperature (saturation or dew point temperature) and the inlet temperature (temperature or saturation temperature for single-component and azeotropic mixtures). This temperature glide would be due to pressure drop in the case of single-component and azeotropic mixtures (negative values), or due to a combination of pressure drop and actual thermodynamic properties of the zeotropic mixtures (negative and positive values possible). As Figure 4 shows, some of the R-22 alternative refrigerants, including R-444B and ARM-20B, have a significantly different evaporator glide from the baseline refrigerant. This would result in suboptimal performance if the capillary tube and charge were modified to match the superheat of the baseline system. Also, for R-444B, the glide is positive for all test conditions; hence, modified refrigerant circuitry would greatly enhance the performance, since the evaporator can be designed as a counter-cross heat exchanger to improve its effectiveness. 


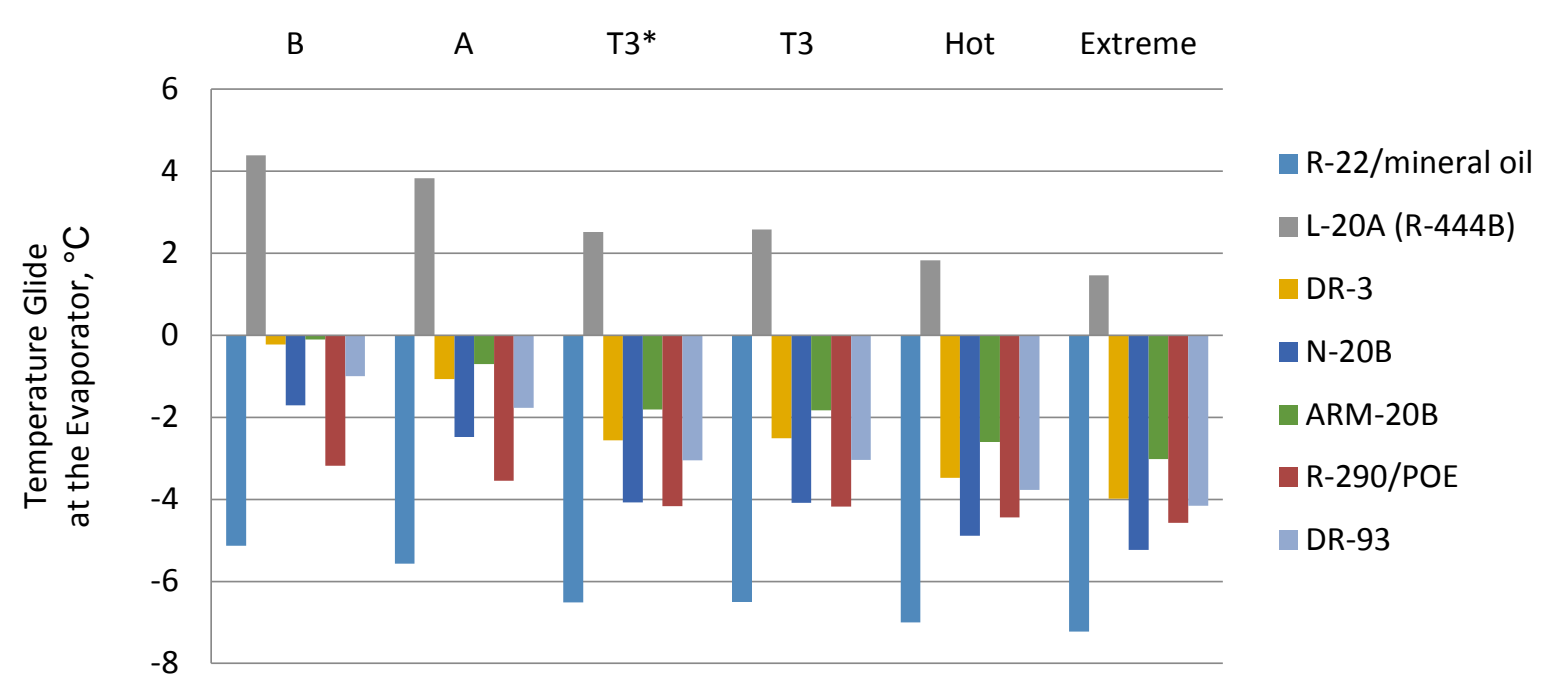

Figure 4. Temperature glide at the evaporator for $\mathrm{R}-22$ and its alternatives.

Based on the uncertainty analysis described in Section 6.3, the air-side capacity has an uncertainty of $\pm 2.3 \%$ and the air-side COP has an uncertainty of $2.4 \%$. Considering these uncertainties and the potential for further performance enhancements, refrigerants with performance values within $5 \%$ of the baseline may be expected to match the performance of R-22 with further soft-optimization; whereas refrigerants within $10 \%$ of the baseline may require only additional engineering to achieve the same performance as the baseline refrigerant. For performance losses greater than $10 \%$, significant redesign of the unit would likely be necessary to match the performance of the baseline.

Table 7 shows the refrigerant charge masses used in the R-22 unit after the optimization process described in Section 5.2. The charges for the alternatives range from $48 \%$ lower (R-290) to 47\% higher (N-20B) than the baseline charge.

Table 7. Optimized refrigerant charge masses for the R-22 unit

\begin{tabular}{|r|c|c|l|}
\hline \multicolumn{1}{|c|}{ Refrigerant } & Manufacturer & $\begin{array}{c}\text { ASHRAE } \\
\text { safety class }\end{array}$ & $\begin{array}{c}\text { Charge mass } \\
\text { kg (oz) }\end{array}$ \\
\hline R-22 (baseline) & - & A1 & $1.417(50)$ \\
\hline N-20B & Honeywell & A1 & $2.087(73.6)$ \\
DR-3 & Chemours & A2L & $2.007(70.8)$ \\
ARM-20B & Arkema & A2L & $1.588(56)$ \\
L-20A (R-444B) & Honeywell & A2L & $1.568(55.3)$ \\
R-290 & - & A3 & $0.731(25.8)$ \\
DR-93 & Chemours & A1 & $1.828(64.5)$ \\
\hline
\end{tabular}

Table 8 summarizes the results of testing the baseline refrigerant and alternatives in the R-22 unit at moderate ambient temperatures (AHRI B and A conditions).

\footnotetext{
* Section 6.3 also includes a discussion of the energy balance for R-22, R-410A, and their alternatives.
} 
Table 8. Test results for $\mathrm{R}-22$ and its alternatives at moderate ambient temperatures (performance change from baseline in parentheses) ${ }^{a, b}$

\begin{tabular}{|r|c|c|c|c|}
\hline & \multicolumn{2}{|c|}{ AHRI B } & \multicolumn{2}{c|}{ AHRI A } \\
& Outdoor: $27.8^{\circ} \mathrm{C}\left(82^{\circ} \mathrm{F}\right)$ & Cutdoor: $35.0^{\circ} \mathrm{C}\left(95^{\circ} \mathrm{F}\right)$ \\
\hline & COP & Capacity & 3.07 & Capacity \\
\hline R-22 (baseline) & 3.48 & 6.26 & $2.68(-13 \%)$ & 5.10 \\
\hline N-20B & $3.04(-13 \%)$ & $5.42(-13 \%)$ & $2.57(-16 \%)$ & $5.40(-12 \%)$ \\
\hline DR-3 & $2.88(-17 \%)$ & $5.52(-12 \%)$ & $2.71(-12 \%)$ & $5.91(-3 \%)$ \\
\hline ARM-20B & $3.06(-12 \%)$ & $6.05(-3 \%)$ & $2.72(-11 \%)$ & $5.58(-9 \%)$ \\
\hline L-20A (R-444B) & $3.02(-13 \%)$ & $5.53(-12 \%)$ & $3.30(+7 \%)$ & $5.62(-8 \%)$ \\
\hline R-290 & $3.85(+11 \%)$ & $5.93(-5 \%)$ & $2.63(-14 \%)$ & $5.70(-7 \%)$ \\
\hline DR-93 & $3.00(-14 \%)$ & $5.92(-5 \%)$ & & \\
\hline
\end{tabular}

${ }^{a}$ Shading - green: performance improvement; blank: 0-5\% degradation; yellow: 5-10\% degradation; orange: >10\% degradation.

${ }^{b}$ The $5 \%$ losses may be nullified by further soft-optimization, whereas $10 \%$ losses may require additional engineering, and losses greater than $10 \%$ may require complete redesign of the unit.

Table 9 summarizes the results of testing the baseline refrigerant and alternatives in the R-22 unit at the T3* and T3 test conditions.

Table 9. Test results for R-22 and its alternatives at the T3* and T3 test conditions (performance change from baseline in parentheses) ${ }^{a, b}$

\begin{tabular}{|c|c|c|c|c|}
\hline & \multicolumn{2}{|c|}{$\begin{array}{c}\text { T3}^{*} \\
\text { Outdoor: } 46.0^{\circ} \mathrm{C}\left(114.8^{\circ} \mathrm{F}\right) \\
\text { Indoor: } 26.7^{\circ} \mathrm{C}\left(80.0^{\circ} \mathrm{F}\right)\end{array}$} & \multicolumn{2}{|c|}{$\begin{array}{c}\mathbf{T 3} \\
\text { Outdoor: } 46.0^{\circ} \mathrm{C}\left(114.8^{\circ} \mathrm{F}\right) \\
\text { Indoor: } 29.0^{\circ} \mathrm{C}\left(84.2^{\circ} \mathrm{F}\right) \\
\end{array}$} \\
\hline & COP & Capacity & COP & Capacity \\
\hline R-22 (baseline) & 2.34 & 5.41 & 2.34 & 5.42 \\
\hline $\mathrm{N}-20 \mathrm{~B}$ & $2.05(-12 \%)$ & $4.56(-16 \%)$ & $2.06(-12 \%)$ & $4.59(-15 \%)$ \\
\hline DR-3 & $1.99(-15 \%)$ & $4.81(-11 \%)$ & $2.01(-14 \%)$ & $4.83(-11 \%)$ \\
\hline ARM-20B & $2.09(-11 \%)$ & $5.28(-2 \%)$ & $2.07(-11 \%)$ & $5.24(-3 \%)$ \\
\hline L-20A (R-444B) & $2.15(-8 \%)$ & $5.17(-4 \%)$ & $2.17(-7 \%)$ & $5.19(-4 \%)$ \\
\hline $\mathrm{R}-290$ & $2.49(+6 \%)$ & $4.90(-10 \%)$ & $2.49(+7 \%)$ & $4.91(-9 \%)$ \\
\hline DR-93 & $2.00(-15 \%)$ & $4.99(-8 \%)$ & $2.02(-13 \%)$ & $5.05(-7 \%)$ \\
\hline
\end{tabular}

${ }^{a}$ Shading-green: performance improvement; blank: 0-5\% degradation; yellow: 5-10\% degradation; orange: >10\% degradation.

${ }^{b}$ The $5 \%$ losses may be nullified by further soft-optimization, whereas $10 \%$ losses may require additional engineering, and losses greater than $10 \%$ may require complete redesign of the unit.

Table 10 summarizes the results of testing the baseline refrigerant and alternatives in the R-22 unit at high ambient temperatures. 
Table 10. Test results for $\mathrm{R}-22$ and its alternatives at high ambient temperatures (performance change from baseline in parentheses) ${ }^{a, b}$

\begin{tabular}{|r|c|c|c|c|}
\hline & \multicolumn{2}{|c|}{ Hot ambient } & \multicolumn{2}{c|}{$\begin{array}{c}\text { Extreme ambient } \\
\text { Outdoor: } 55^{\circ} \mathrm{C}\left(131^{\circ} \mathrm{F}\right)\end{array}$} \\
\hline & CoP & Capacity & COP & Capacity \\
\hline R-22 (baseline) & 1.98 & 5.00 & 1.82 & 4.76 \\
\hline N-20B & $1.77(-11 \%)$ & $4.26(-15 \%)$ & $1.64(-10 \%)$ & $4.1(-14 \%)$ \\
\hline DR-3 & $1.7(-14 \%)$ & $4.41(-12 \%)$ & $1.55(-15 \%)$ & $4.21(-12 \%)$ \\
\hline ARM-20B & $1.76(-11 \%)$ & $4.84(-3 \%)$ & $1.61(-11 \%)$ & $4.62(-3 \%)$ \\
\hline L-20A (R-444B) & $1.85(-7 \%)$ & $4.79(-4 \%)$ & $1.69(-7 \%)$ & $4.59(-4 \%)$ \\
\hline R-290 & $2.12(+7 \%)$ & $4.5(-10 \%)$ & $1.96(+8 \%)$ & $4.33(-9 \%)$ \\
\hline DR-93 & $1.70(-14 \%)$ & $4.63(-7 \%)$ & $1.54(-15 \%)$ & $4.38(-8 \%)$ \\
\hline
\end{tabular}

${ }^{a}$ Shading—green: performance improvement; blank: 0-5\% degradation; yellow: 5-10\% degradation; orange: $>10 \%$ degradation.

${ }^{b}$ The $5 \%$ losses may be nullified by further soft-optimization, whereas $10 \%$ losses may require additional engineering, and losses greater than $10 \%$ may require complete redesign of the unit.

\subsubsection{COP and Cooling Capacity Performance}

Figure 5 shows the COP for each refrigerant at each test condition. For all refrigerants, including R-22, the efficiency degraded with the increase in ambient temperature. The percentage of efficiency degradation associated with increasing ambient temperature was roughly consistent for both the R-22 baseline and all the alternatives; the COP degraded approximately $40 \%$ as the ambient temperature increased from AHRI A to Extreme conditions (for detailed data on COP at each test condition relative to the COP at AHRI A conditions, refer to Figure D.3 in APPENDIX D). The system COP (Figure 5) was the highest using R-290 compared with all other refrigerants, including the baseline, at all test conditions. On the other hand, the system capacity (Figure 6) was the highest using the baseline refrigerant compared with all other refrigerants including R-290. The system COP using the baseline refrigerant was also higher compared with the other alternatives at all test conditions.

At the Extreme test conditions, R-290 resulted in 8\% higher COP than the baseline. R-444B resulted in the second-highest COP at 7\% lower than the baseline refrigerant. ARM-20B, N-20B, and DR-93 resulted in system efficiencies similar to that of R-444B at moderate temperature conditions, but the system efficiencies for these three alternatives had larger degradation at higher ambient temperatures; the corresponding COPs were, respectively, 11, 10, and 15\% lower than with the baseline under Extreme test conditions, compared with the aforementioned $7 \%$ for R-444B. 


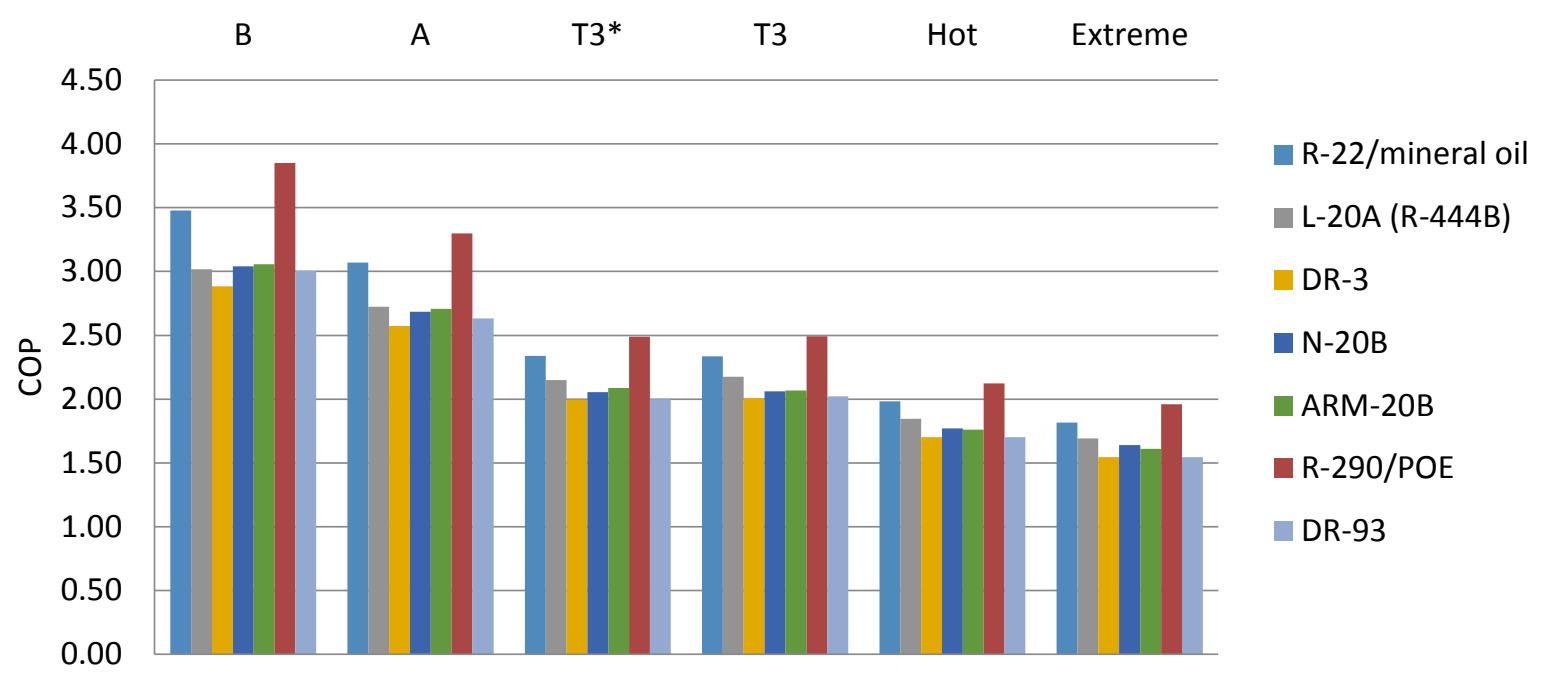

Figure 5. COP for R-22 and its alternatives at each test condition.

Figure 6 shows the cooling capacity for each refrigerant at each test condition. For all tested refrigerants, including R-22, the cooling capacity degraded as the ambient temperature increased. The amount of capacity degradation varied by refrigerant (for a detailed view of cooling capacity at each test condition relative to the cooling capacity at AHRI A conditions, refer to Figure D.4 in APPENDIX D). As previously mentioned, the baseline refrigerant yielded a higher cooling capacity than the alternatives at all test conditions. ARM-20B resulted in the highest cooling capacity of all the alternatives at each test condition. At moderate temperature conditions (AHRI B and AHRI A), ARM-20B had a 3\% loss compared with the baseline; it was followed closely by DR-93, which had a 5\% loss at AHRI B and a 7\% loss at AHRI A. Under high ambient temperatures (Hot and Extreme), R-444B and ARM-20B yielded similar capacities (4\% and 3\% degradation compared with the baseline, respectively). DR-93 resulted in cooling capacity losses of 7 and 8\% compared with the baseline at Hot and Extreme conditions, respectively. Under the same conditions, R-290 resulted in a 9-10\% cooling capacity loss compared with the baseline.

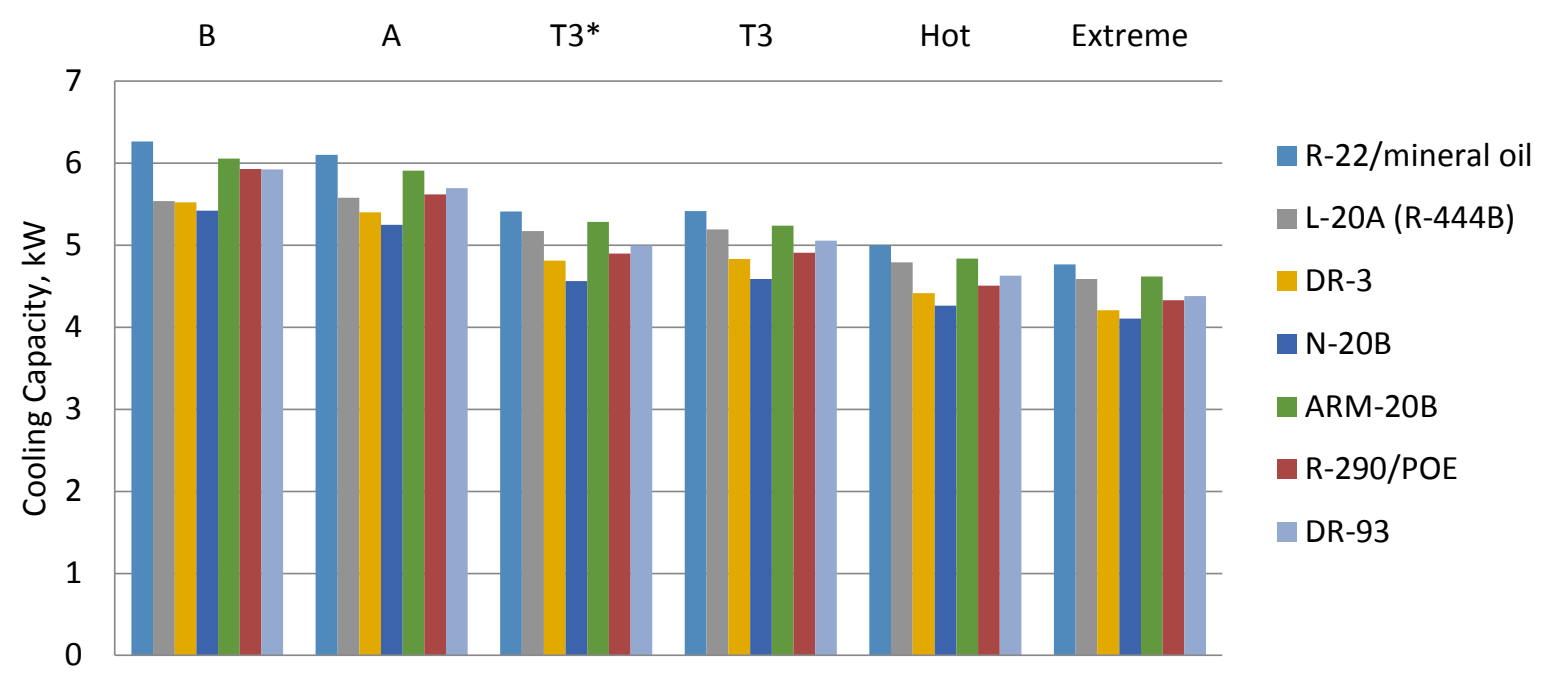

Figure 6. Cooling capacity for R-22 and its alternatives at each test condition. 


\subsubsection{Performance Relative to Baseline}

Another way to visualize the system performance using the alternative refrigerant is to normalize the COP and cooling capacity using the corresponding COP and cooling capacity of the baseline system at the same test conditions. Figure 7 compares the COP and capacity of the alternative refrigerants with that of the baseline under AHRI A test conditions. R-290 led to 8\% less cooling capacity than the baseline, but $7 \%$ higher COP. ARM-20B nearly matched the cooling capacity of the baseline (3\% degradation), though with a $12 \%$ drop in COP. The COP was approximately $11 \%$ lower for R-444B compared with the baseline, while its cooling capacity was less than $10 \%$ below the baseline. DR-93 resulted in $93 \%$ of the cooling capacity of the baseline, but only $86 \%$ of the COP. DR-3 and N-20B both yielded less than $90 \%$ of the COP and the cooling capacity of the baseline.

Performance Relative to Baseline at AHRI A Conditions $35^{\circ} \mathrm{C}\left[95^{\circ} \mathrm{F}\right]$ Outdoor and $27^{\circ} \mathrm{C}\left[80^{\circ} \mathrm{F}\right]$ Indoor

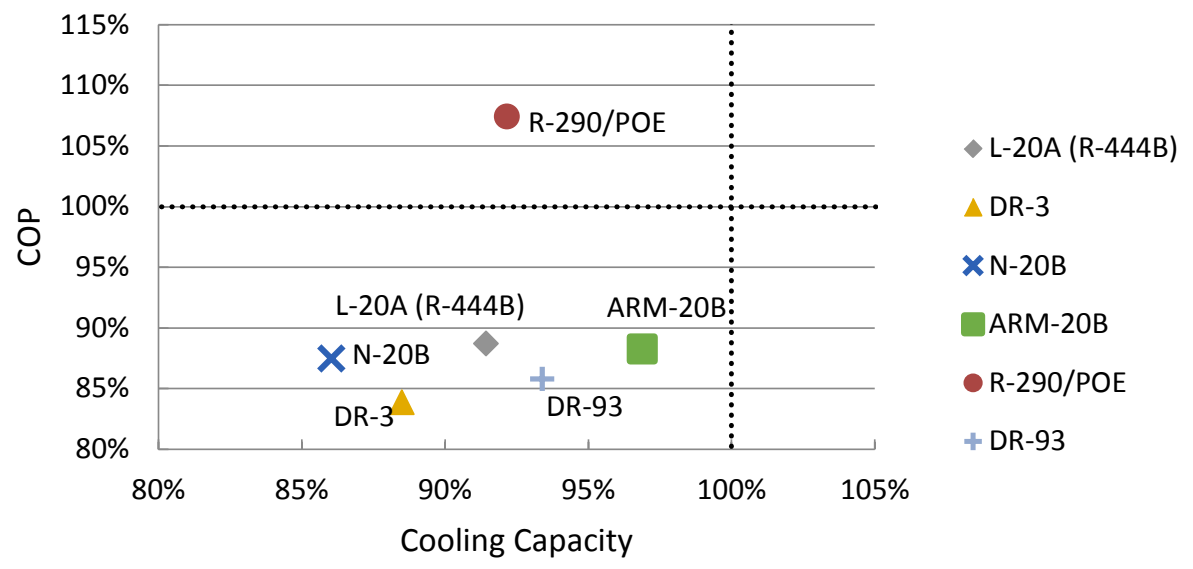

Figure 7. Performance of alternative refrigerants compared with that of R-22 (mineral oil) at AHRI A test conditions (outdoor temperature $35^{\circ} \mathrm{C}$ and indoor temperature $27^{\circ} \mathrm{C}$ ).

Figure 8 compares the COP and cooling capacity of the alternative refrigerants with the baseline under the ISO T3 test conditions. Under ISO T3 test conditions, where the outdoor temperature is $11^{\circ} \mathrm{C}$ higher than under the AHRI A conditions, R-290 outperformed the baseline COP by 7\%, but with a $9 \%$ loss of cooling capacity. ARM-20B and R-444B performed very close to the baseline in terms of capacity (higher than $95 \%$ of the baseline capacity), but their COPs were still 11 and 7\% below that of the baseline, respectively. The relative performance of DR-93 and N-20B compared with the baseline remained approximately the same as at AHRI A conditions, in terms of both COP and capacity, whereas the COP of DR-3 improved slightly relative to the baseline. 


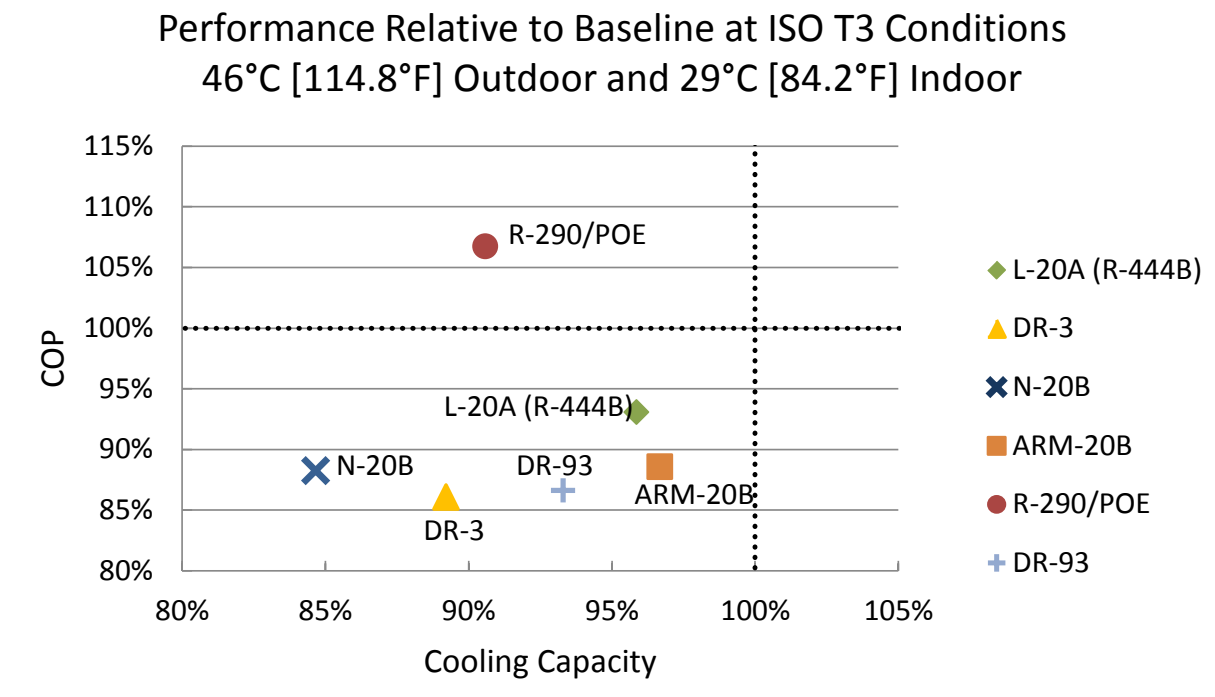

Figure 8. Performance of alternative refrigerants compared with R-22 (mineral oil) at ISO T3 (outdoor temperature $46^{\circ} \mathrm{C}$ and indoor temperature $29^{\circ} \mathrm{C}$ ).

Figure 9 compares the COP and cooling capacity of the alternative refrigerants with the baseline under Hot test conditions. In general, the relative performance of the refrigerants compared with the baseline is similar to that observed under the ISO T3 conditions.

Performance Relative to Baseline at Hot Conditions $52^{\circ} \mathrm{C}\left[125.6^{\circ} \mathrm{F}\right]$ Outdoor and $29^{\circ} \mathrm{C}\left[84.2^{\circ} \mathrm{F}\right]$ Indoor

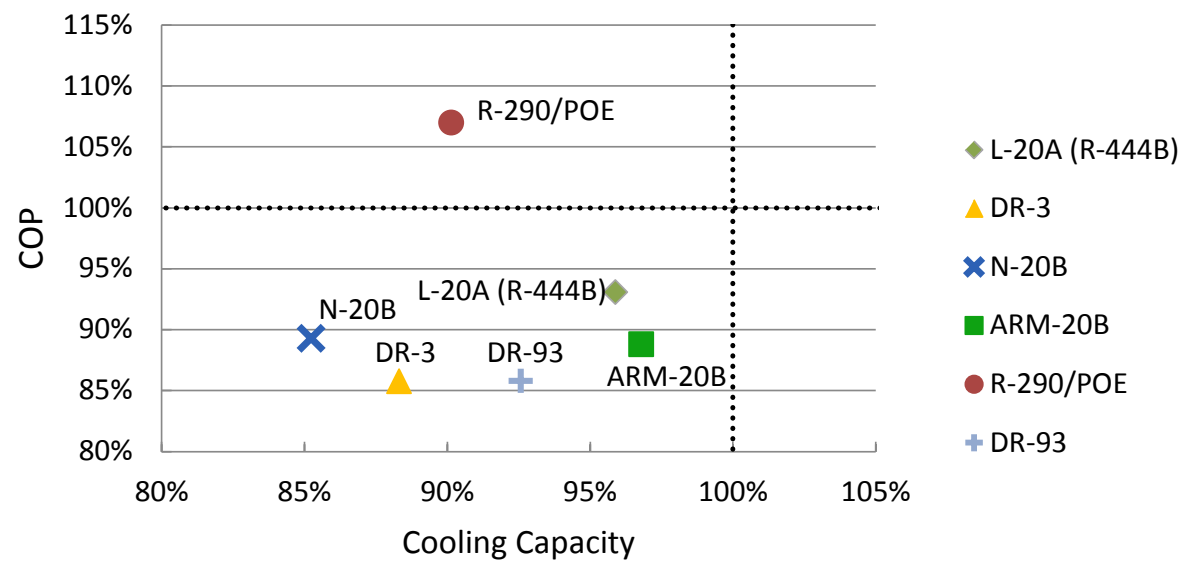

Figure 9. Performance of alternative refrigerants compared with R-22 (mineral oil) at Hot test conditions (outdoor temperature $52^{\circ} \mathrm{C}$ and indoor temperature $29^{\circ} \mathrm{C}$ ).

Figure 10 compares the $\mathrm{COP}$ and capacity of the alternative refrigerants with the baseline under Extreme test conditions. Once again, R-290 resulted in a higher COP than the baseline (by 8\%), but with a loss in cooling capacity (9\% loss). ARM-20B yielded a higher cooling capacity but lower COP than R-444B. For the AHRI A, T3, Hot, and Extreme conditions, DR-3 led to a higher cooling capacity and lower COP than $\mathrm{N}-20 \mathrm{~B}$. The relative COP of DR-93 compared with the baseline remained roughly constant throughout all test conditions, but the results indicate a marginal drop in capacity relative to the baseline. 
Performance Relative to Baseline at Extreme Conditions $55^{\circ} \mathrm{C}\left[131^{\circ} \mathrm{F}\right]$ Outdoor and $29^{\circ} \mathrm{C}\left[84.2^{\circ} \mathrm{F}\right]$ Indoor

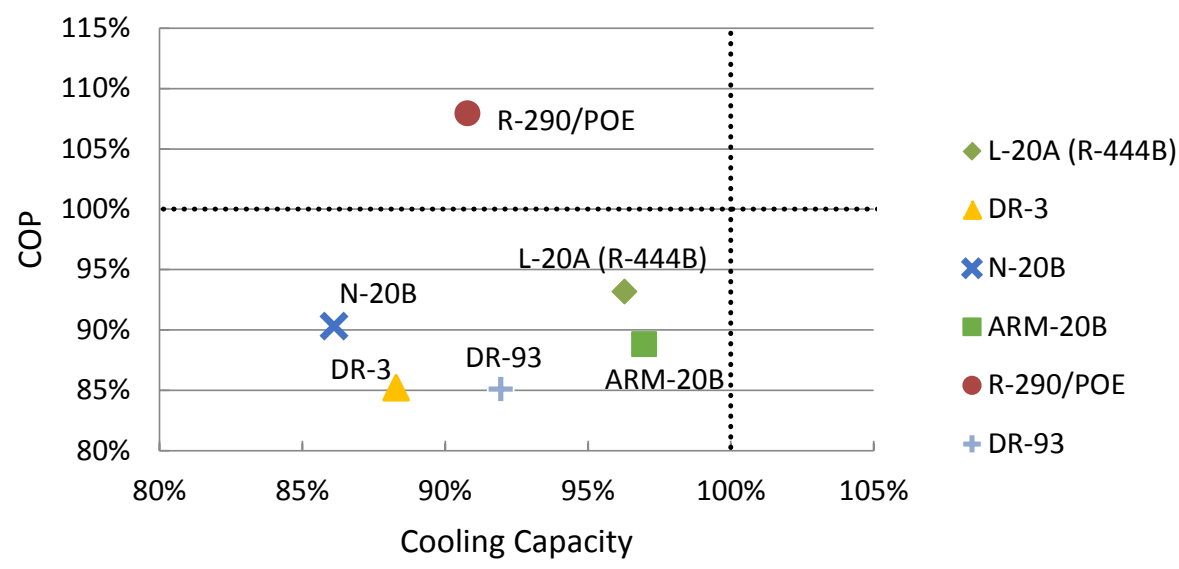

Figure 10. Performance of alternative refrigerants compared with R-22 (mineral oil) at Extreme test conditions (outdoor temperature $55^{\circ} \mathrm{C}$ and indoor temperature $29^{\circ} \mathrm{C}$ ).

Figure 11 shows the difference between the compressor discharge temperatures of each refrigerant compared with the baseline, at each test condition. Temperatures up to $5^{\circ} \mathrm{C}$ above the baseline are considered acceptable, whereas temperatures above that may require further engineering to avoid compressor reliability issues and issues with lubricant breakdown. For most refrigerants, the compressor discharge temperature was in fact lower than for the baseline. The compressor discharge temperature was higher than the baseline for R-444B at all test conditions, and only at high ambient temperatures for ARM-20B.

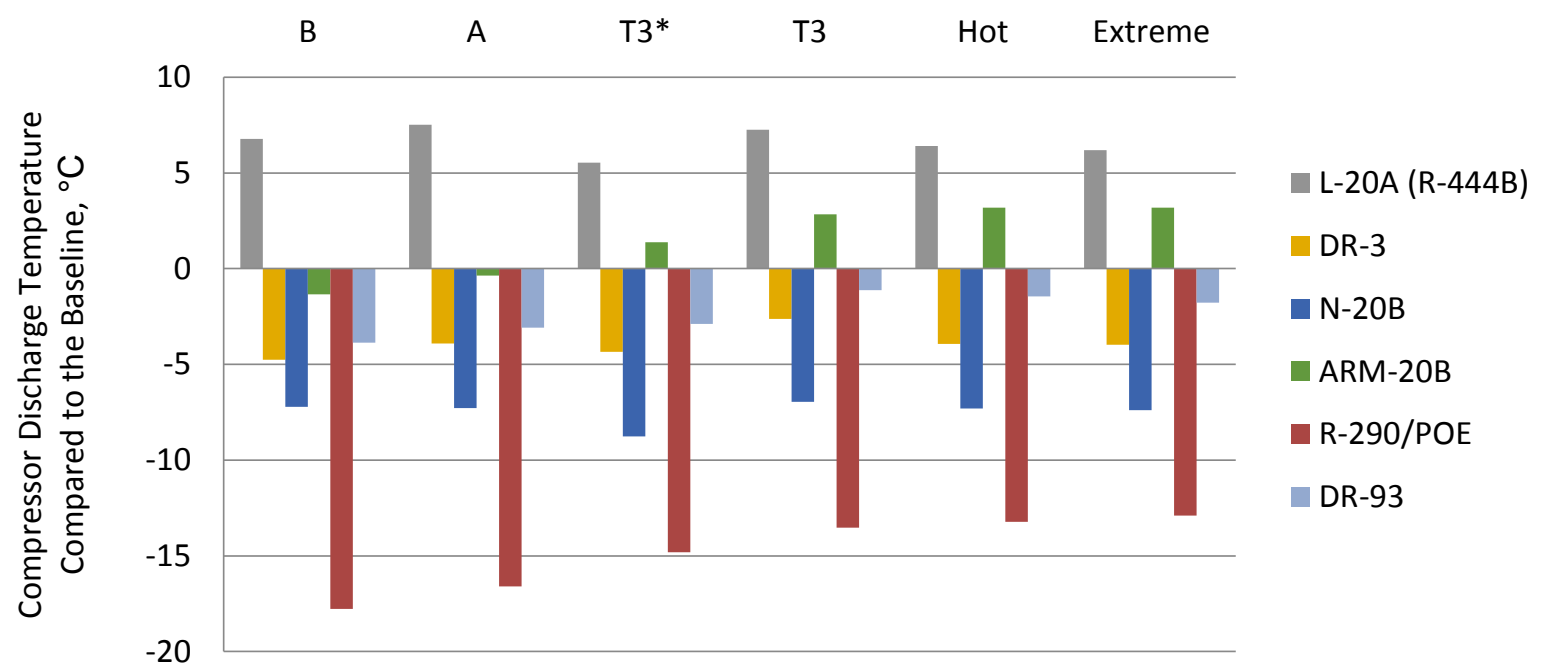

Figure 11. Compressor discharge temperature of the alternative refrigerants, difference compared with the baseline. 


\subsubsection{Performance by Refrigerant}

Figure 12 shows the performance of R-290 compared with that of the baseline for each test condition. R-290 resulted in a more than 6\% higher COP than the baseline at all test conditions, and its cooling capacity was within $-10 \%$ of the baseline. It led to slightly higher performance at moderate ambient temperatures than at the other test conditions, but the results are similar considering the experimental uncertainty.

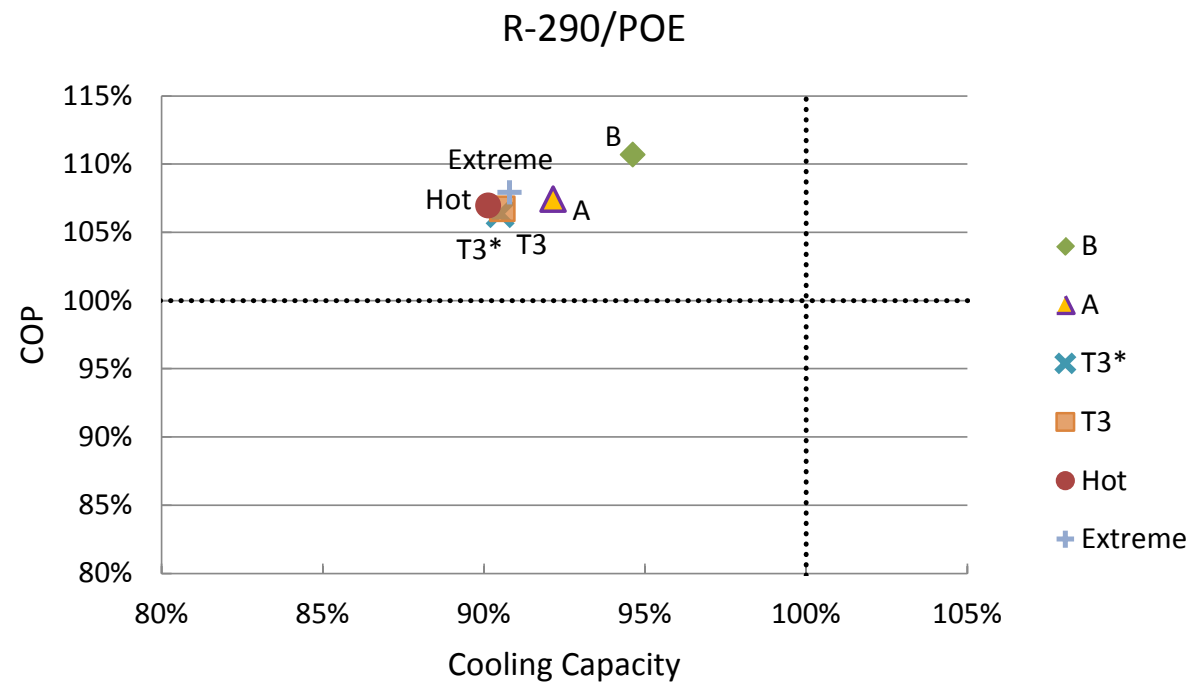

Figure 12. Performance of R-290 compared with R-22 (mineral oil) at each test condition.

Figure 13 shows the performance of R-444B compared with that of R-22 (mineral oil) for each test condition. The relative performance of R-444B improved from AHRI B to AHRI A conditions, and again from AHRI A to T3, for both capacity and COP. At the T3, T3*, Hot and Extreme test conditions, the relative performance of R-444B compared with the baseline remained approximately constant.

$L-20 A(R-444 B)$

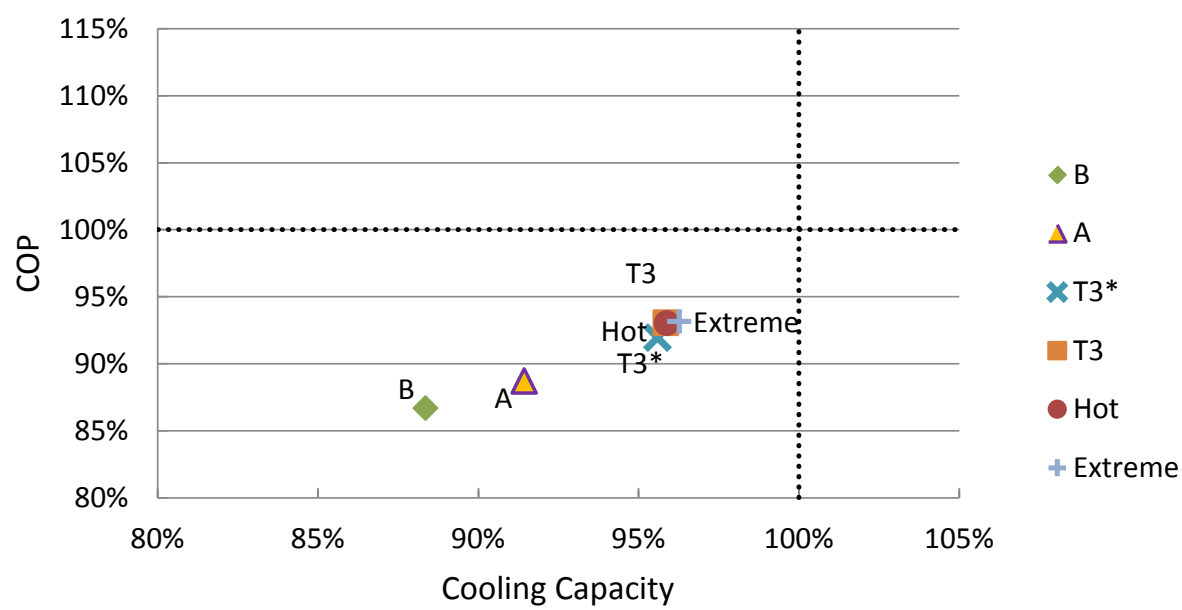

Figure 13. Performance of R-444B compared with R-22 (mineral oil) at each test condition. 
Figure 14 shows the performance of ARM-20B compared with that of R-22 (mineral oil) for each test condition. The performance of ARM-20B remained roughly constant compared with R-22 (mineral oil), in terms of both COP and cooling capacity. In other words, as temperature increased, the performances of ARM-20B and R-22 (mineral oil) degraded at a similar rate.

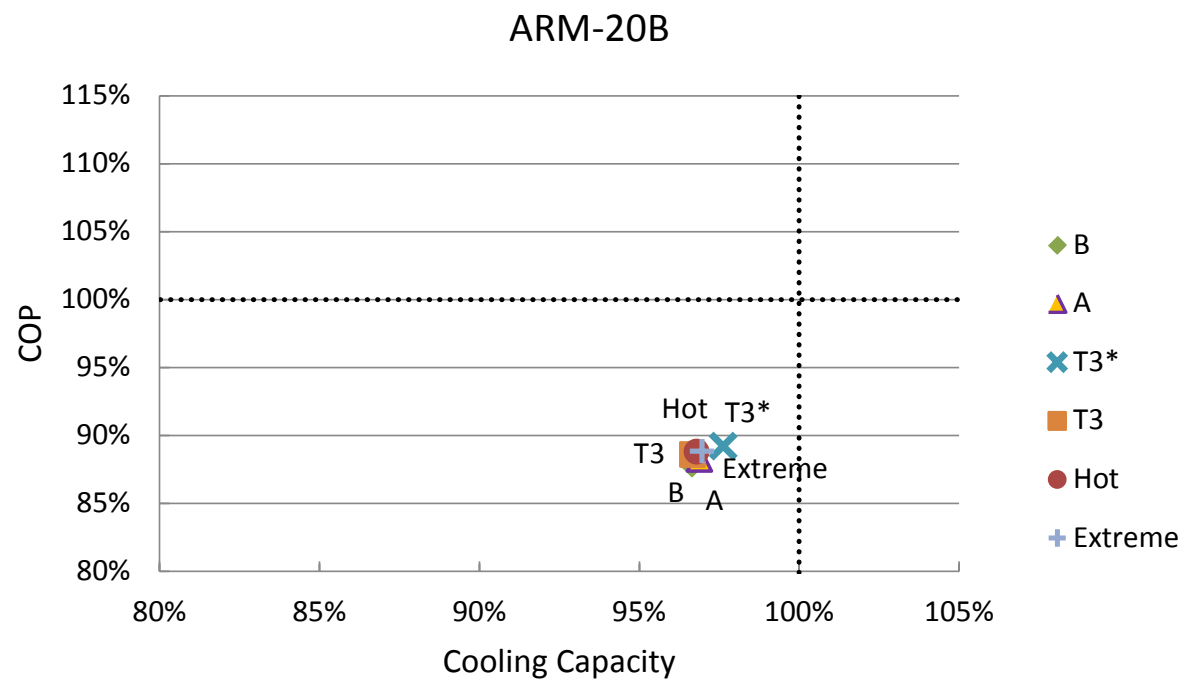

Figure 14. Performance of ARM-20B compared with R-22 (mineral oil) at each test condition.

See APPENDIX D for additional results, including detailed data tables.

The re-test of the unit with R-22 and mineral oil at the end of the testing (results given in APPENDIX D) showed that the unit performed within $-3.6 \%$ of the cooling capacity and $-4.4 \%$ of the COP. These results suggest that the extended testing with all the alternative refrigerants resulted in minimal performance degradation and that the system reliability was not affected by the use of the alternative refrigerants.

\subsection{RESULTS FOR THE R-410A UNIT}

This section describes the results for R-410A and its alternatives at all test conditions (AHRI A and B, ISO T3, T3*, Hot, and Extreme) and then presents the results for the AHRI A, ISO T3, Hot, and Extreme test conditions in more detail to show performance trends as ambient temperature changes. Furthermore, the results for the three alternative refrigerants generally showing the best performance are presented in greater detail.

The five alternative refrigerants (as discussed in Section 4.2) are R-32, DR-55, L-41 (R-447A), ARM-71a and HPR-2A, all using POE oil as a lubricant. To assess the unit durability and the repeatability of the results with the alternative refrigerants, ORNL also conducted an additional round of tests with R-410A after all alternatives had been tested. The results for that round of testing are included in APPENDIX E.

As discussed in Section 6.1, the temperature glide must be considered, as it can affect the performance of the unit as well as direct further engineering of the unit for use with a given refrigerant. As seen in Figure 15, the glide is positive for a number of alternatives to R-410A (R-447A, ARM-71a, and HPR-2A).

Hence, modified refrigerant circuitry would greatly enhance the performance, since the evaporator can be designed as a counter-cross heat exchanger to improve its effectiveness. 


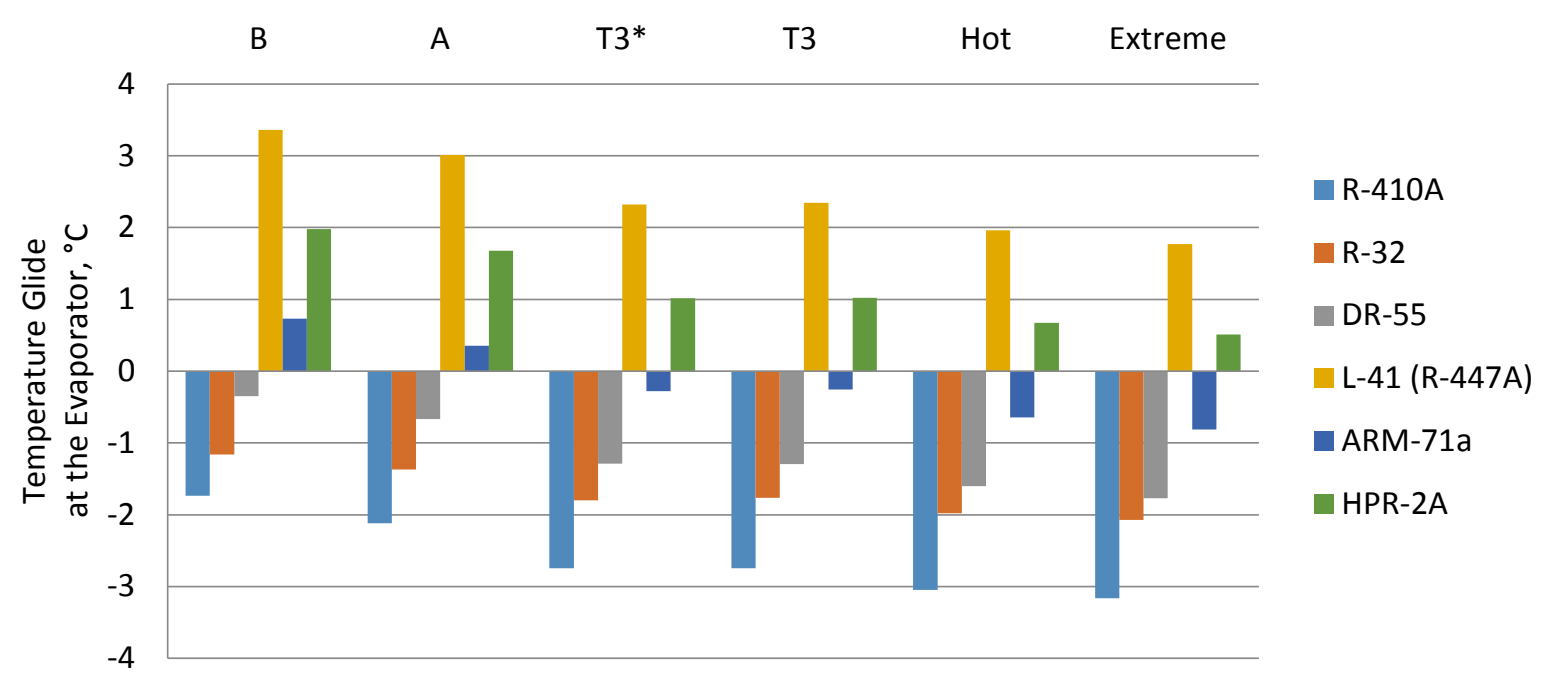

Figure 15. Temperature glide at the evaporator for $\mathrm{R}-410 \mathrm{~A}$ and its alternatives.

The uncertainty analysis described in Section 6.3 shows that the air-side capacity has an uncertainty of $\pm 1.5 \%$ and the COP an uncertainty of $\pm 1.6 \%$. Considering these uncertainties and the potential for further performance enhancements, refrigerants with performance values within $5 \%$ of the baseline may be expected to match the performance of R-410A with further soft-optimization, whereas refrigerants within $10 \%$ of the baseline may require only additional engineering design to achieve the same performance as the baseline. For performance losses greater than $10 \%$, significant redesign of the unit would likely be necessary to match the performance of the baseline.

Table 11 shows the refrigerant charge masses used in the R-410A unit after the optimization process described in Section 5.2. The range of required charge levels is much narrower for the R-410A alternatives than for the R-22 alternatives (Table 7). Also, all of the alternatives require less charge than the baseline refrigerant (from 13 to $24 \%$ less).

Table 11. Optimized refrigerant charge masses for the $\mathrm{R}-410 \mathrm{~A}$ unit

\begin{tabular}{|r|c|c|l|}
\hline \multicolumn{1}{|c|}{ Refrigerant } & Manufacturer & $\begin{array}{c}\text { ASHRAE } \\
\text { safety class }\end{array}$ & $\begin{array}{c}\text { Charge mass } \\
\text { kg (oz) }\end{array}$ \\
\hline R-410A (baseline) & - & A1 & $0.936(33)$ \\
\hline R-32 & Daikin & A2L & $0.709(25)$ \\
DR-55 & Chemours & A2L & $0.811(28.6)$ \\
L-41 (R-447A) & Honeywell & A2L & $0.780(27.5)$ \\
ARM-71A & Arkema & A2L & $0.765(27)$ \\
HPR-2A & Mexichem & A2L & $0.808(28.5)$ \\
\hline
\end{tabular}

Table 12 summarizes the results of testing the baseline refrigerant and alternatives in the R-410A unit at moderate ambient temperatures (AHRI B and A conditions).

\footnotetext{
* Section 6.3 also includes a discussion of the energy balance for R-22, R-410A, and their alternatives.
} 
Table 12. Test results for R-410A and its alternatives at moderate ambient temperatures (performance change from baseline in parentheses) ${ }^{a, b}$

\begin{tabular}{|r|c|c|c|c|}
\hline & \multicolumn{2}{|c|}{ AHRI B } & \multicolumn{2}{c|}{ AHRI A } \\
& Outdoor: $27.8^{\circ} \mathrm{C}\left(82^{\circ} \mathrm{F}\right)$ & Cutdoor: $35.0^{\circ} \mathrm{C}\left(95^{\circ} \mathrm{F}\right)$ \\
\hline & COP & Capacity & 3.40 & Capacity \\
\hline R-410A (baseline) & 3.95 & 5.35 & $3.55(+4 \%)$ & 5.14 \\
\hline R-32 & $3.99(+1 \%)$ & $5.46(+2 \%)$ & $3.5(+3 \%)$ & $5.01(-3 \%)$ \\
\hline DR-55 & $4.03(+2 \%)$ & $5.15(-4 \%)$ & $3.22(-5 \%)$ & $4.44(-14 \%)$ \\
\hline L-41 (R-447A) & $3.62(-8 \%)$ & $4.49(-16 \%)$ & $3.38(-1 \%)$ & $4.75(-8 \%)$ \\
\hline ARM-71a & $3.94(0 \%)$ & $4.97(-7 \%)$ & $3.32(-2 \%)$ & $4.69(-9 \%)$ \\
\hline HPR-2A & $3.69(-7 \%)$ & $4.69(-12 \%)$ & & \\
\hline
\end{tabular}

${ }^{a}$ Shading - green: performance improvement; blank: 0-5\% degradation; yellow: 5-10\% degradation; orange: >10\% degradation.

${ }^{b}$ The $5 \%$ losses may be nullified by further soft-optimization, whereas $10 \%$ losses may require additional engineering, and losses greater than $10 \%$ may require complete redesign of the unit.

Table 13 summarizes the results of testing the baseline refrigerant and alternatives in the R-410A unit at the T3* and T3 test conditions.

Table 13. Test results for $\mathrm{R}-410 \mathrm{~A}$ and its alternatives at the $\mathrm{T} 3 *$ and $\mathrm{T} 3$ test conditions (performance change from baseline in parentheses) ${ }^{a, b}$

\begin{tabular}{|r|c|c|c|c|}
\hline & \multicolumn{2}{|c|}{$\mathbf{T 3}^{*}$} & \multicolumn{2}{c|}{ T3 } \\
& \multicolumn{2}{|c|}{$\begin{array}{c}\text { Outdoor: } 46.0^{\circ} \mathrm{C}\left(114.8^{\circ} \mathrm{F}\right) \\
\text { Indoor: } 26.7^{\circ} \mathrm{C}\left(80.0^{\circ} \mathrm{F}\right)\end{array}$} & \multicolumn{2}{c|}{$\begin{array}{c}\text { Outdoor: } 46.0^{\circ} \mathrm{C}\left(114.8^{\circ} \mathrm{F}\right) \\
\text { Indoor: } 29.0^{\circ} \mathrm{C}\left(84.2^{\circ} \mathrm{F}\right)\end{array}$} \\
\hline & COP & Capacity & 2.49 & 4.41 \\
\hline R-410A (baseline) & 2.47 & 4.39 & $2.59(+4 \%)$ & $4.79(+9 \%)$ \\
\hline R-32 & $2.57(+4 \%)$ & $4.76(+8 \%)$ & $2.52(+1 \%)$ & $4.27(-3 \%)$ \\
\hline DR-55 & $2.63(+6 \%)$ & $4.42(+1 \%)$ & $2.49(0 \%)$ & $4.03(-9 \%)$ \\
\hline L-41 (R-447A) & $2.48(0 \%)$ & $4.01(-9 \%)$ & $2.48(0 \%)$ & $4.12(-7 \%)$ \\
\hline ARM-71a & $2.52(+2 \%)$ & $4.17(-5 \%)$ & $2.57(+3 \%)$ & $4.27(-3 \%)$ \\
\hline HPR-2A & $2.55(+3 \%)$ & $4.24(-3 \%)$ & & \\
\hline
\end{tabular}

${ }^{a}$ Shading — green: performance improvement; blank: 0-5\% degradation; yellow: 5-10\% degradation.

${ }^{b}$ The $5 \%$ losses may be nullified by further soft-optimization, whereas $10 \%$ losses may require additional engineering, and losses greater than $10 \%$ may require complete redesign of the unit.

Table 14 summarizes the results of testing the baseline refrigerant and alternatives in the R-410A unit at high ambient temperatures. 
Table 14. Test results for $\mathrm{R}-410 \mathrm{~A}$ and its alternatives at high ambient temperatures (performance change from baseline in parentheses) ${ }^{a, b}$

\begin{tabular}{|c|c|c|c|c|}
\hline & \multicolumn{2}{|c|}{$\begin{array}{c}\text { Hot ambient } \\
\text { Outdoor: } 52^{\circ} \mathrm{C}\left(125.6^{\circ} \mathrm{F}\right)\end{array}$} & \multicolumn{2}{|c|}{$\begin{array}{c}\text { Extreme ambient } \\
\text { Outdoor: } 55^{\circ} \mathrm{C}\left(131^{\circ} \mathrm{F}\right)\end{array}$} \\
\hline & COP & Capacity & COP & Capacity \\
\hline R-410A (baseline) & 2.07 & 3.98 & 1.87 & 3.75 \\
\hline $\mathrm{R}-32$ & $2.17(+5 \%)$ & $4.43(+11)$ & $1.98(+6 \%)$ & $4.23(+13 \%)$ \\
\hline DR-55 & $2.14(+3 \%)$ & $3.99(0 \%)$ & $1.93(+3 \%)$ & $3.76(0 \%)$ \\
\hline L-41 (R-447A) & $2.13(+3 \%)$ & $3.77(-6 \%)$ & $1.96(+5 \%)$ & $3.63(-3 \%)$ \\
\hline ARM-71a & $2.11(+2 \%)$ & $3.83(-4 \%)$ & $1.9(+2 \%)$ & $3.62(-3 \%)$ \\
\hline HPR-2A & $2.16(+5 \%)$ & $3.93(-1 \%)$ & $1.98(+6 \%)$ & $3.77(+1 \%)$ \\
\hline
\end{tabular}

${ }^{a}$ Shading-green: performance improvement; blank: 0-5\% degradation; yellow: 5-10\% degradation.

${ }^{b}$ The $5 \%$ losses may be nullified by further soft-optimization, whereas $10 \%$ losses may require additional engineering, and losses greater than $10 \%$ may require complete redesign of the unit.

\subsubsection{COP and Cooling Capacity Performance}

Figure 16 shows the COP for each refrigerant at each test condition. For all refrigerants, including R-410A, the efficiency degraded with increases in ambient temperature. The percentage of efficiency degradation associated with increasing ambient temperature was roughly consistent across all alternative refrigerants; the COP degraded approximately $45 \%$ as the ambient temperature increased from AHRI A to Extreme conditions (for detailed data on COP relative to the COP at AHRI A conditions, refer to Figure E.3 in APPENDIX E). At high ambient temperatures, all five alternatives yielded higher COPs than the baseline.

R-32 and DR-55 led to higher COP than the baseline refrigerant (R-410A) at all test conditions. DR-55 resulted in a $6 \%$ higher COP than the baseline at ISO T3*, which was the highest relative COP of any of the alternatives at those conditions. At the Hot ambient condition, however, R-32 yielded the highest COP of all refrigerants (approximately 5\% higher than the baseline). At the Extreme Ambient condition, R-32 and HPR-2A resulted in the highest COPs (6\% higher than the baseline). ARM-71a led to roughly the same COP as the baseline through all test conditions, with slight improvement at high ambient temperatures. R-447A and HPR-2A had lower COPs than the baseline at moderate ambient temperatures, but they surpassed it at high ambient temperatures. At Extreme conditions, R-447A and HPR-2A led to higher COPs than the baseline by $5 \%$ and $6 \%$, respectively. 


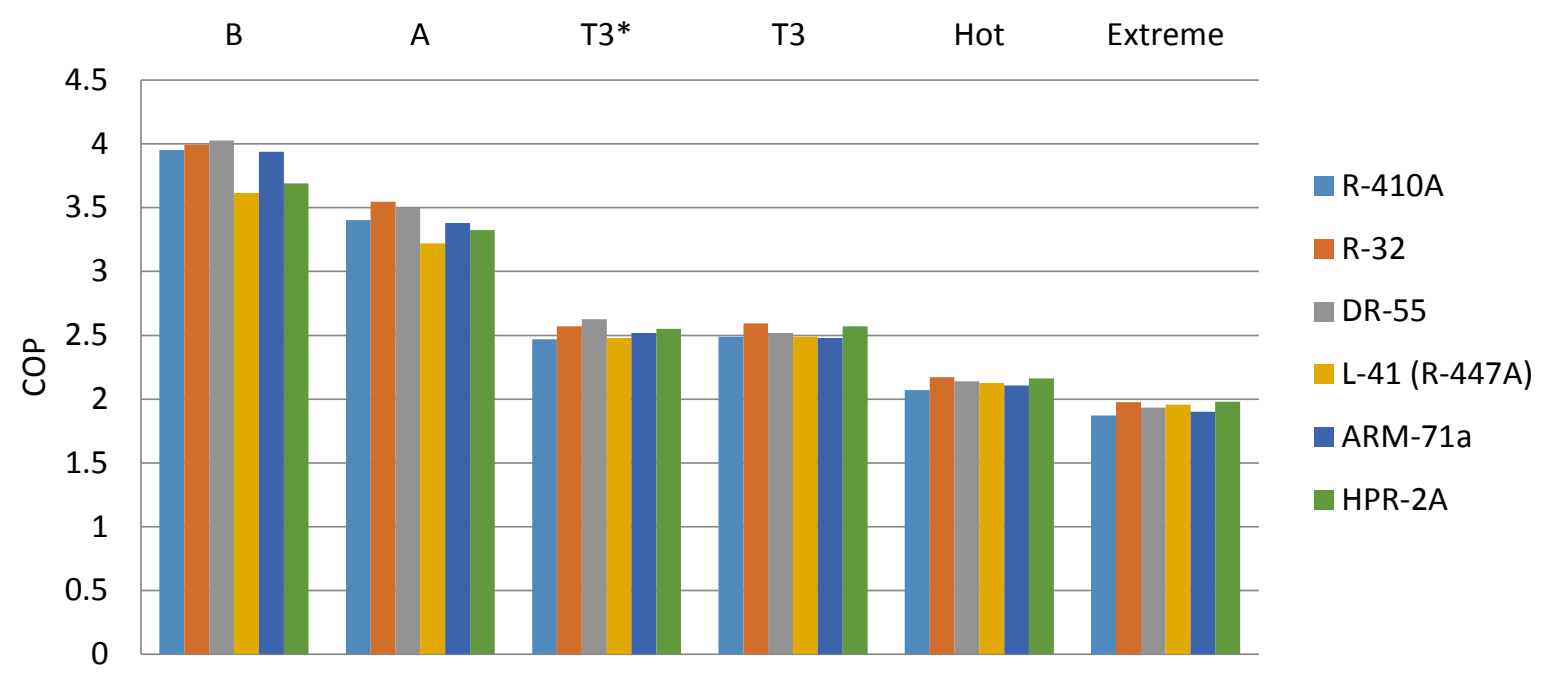

Figure 16. COP for R-410A and its alternatives at each test condition.

Figure 17 shows the cooling capacity for each refrigerant at each test condition. For all tested refrigerants, the cooling capacity degraded as the ambient temperature increased. The amount of capacity degradation varied by refrigerant (for a detailed view of cooling capacity as a function of ambient temperature, refer to Figure E.4 in APPENDIX E). At moderate temperature conditions, the baseline refrigerant yielded a higher cooling capacity than the alternatives, with the exception of R-32. R-32 led to 2\% higher capacity than the baseline at the lowest temperature conditions (AHRI B, $27.8^{\circ} \mathrm{C}$ ) and $13 \%$ higher at the highest temperature conditions (Extreme, $55^{\circ} \mathrm{C}$ ). DR-55 resulted in a similar capacity to the baseline, with its lowest result only 4\% below the baseline. The cooling capacities of ARM-71a, HPR-2A and R-447A all improved compared with the baseline as the temperature increased, and all three delivered within $4 \%$ of the capacity of the baseline at Extreme conditions.

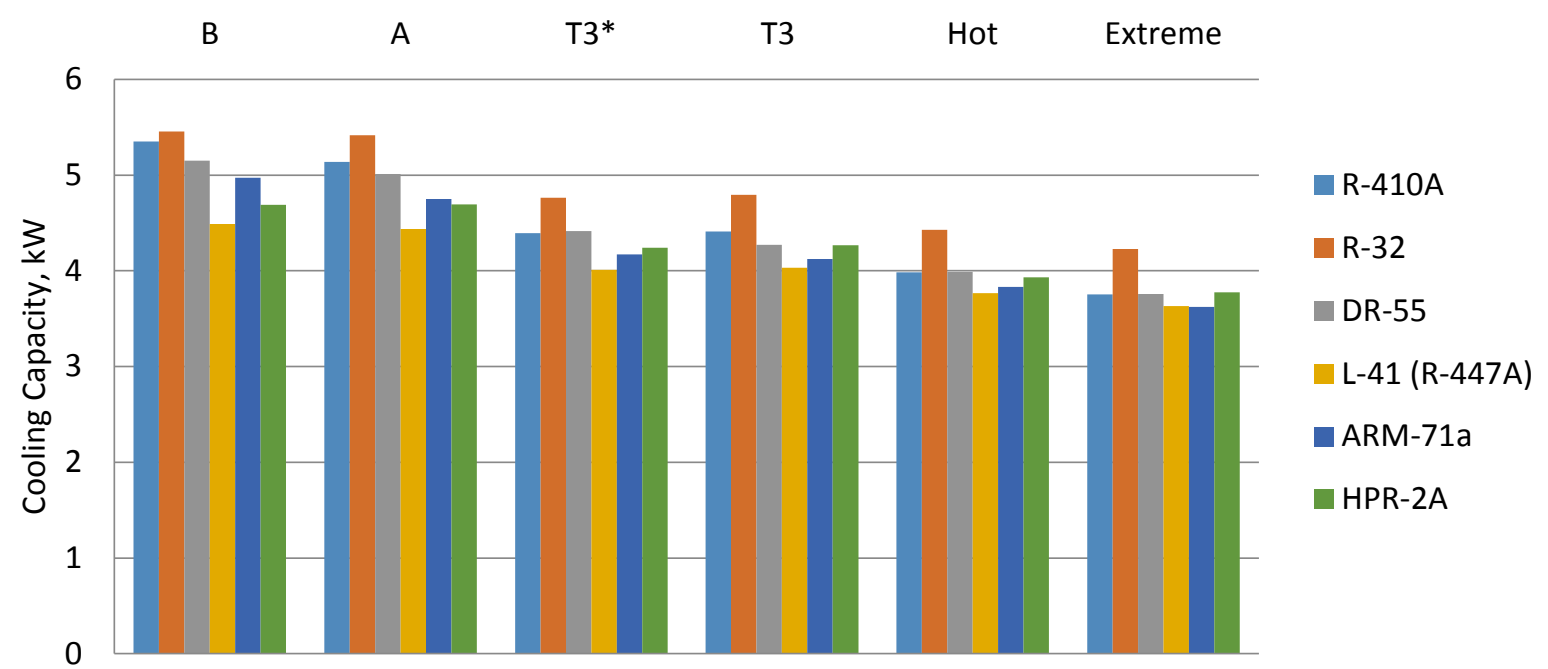

Figure 17. Cooling capacity for R-410A and its alternatives at each test condition. 


\subsubsection{Performance Relative to Baseline}

Figure 18 compares the COP and cooling capacity of the alternative refrigerants with that of the baseline under the AHRI A test conditions. R-32 resulted in approximately 4\% higher COP than the baseline and 5\% higher cooling capacity. DR-55 led to 3\% higher COP than the baseline, but 3\% lower capacity.

ARM-71a nearly matched the COP of the baseline, but with $8 \%$ lower capacity. HPR-2A resulted in 2\% lower COP and 9\% lower capacity compared with the baseline. R-447A yielded 5\% lower COP and 14\% lower capacity than the baseline.

Performance Relative to Baseline at AHRI A Conditions $35^{\circ} \mathrm{C}\left[95^{\circ} \mathrm{F}\right]$ Outdoor and $27^{\circ} \mathrm{C}\left[80^{\circ} \mathrm{F}\right]$ Indoor

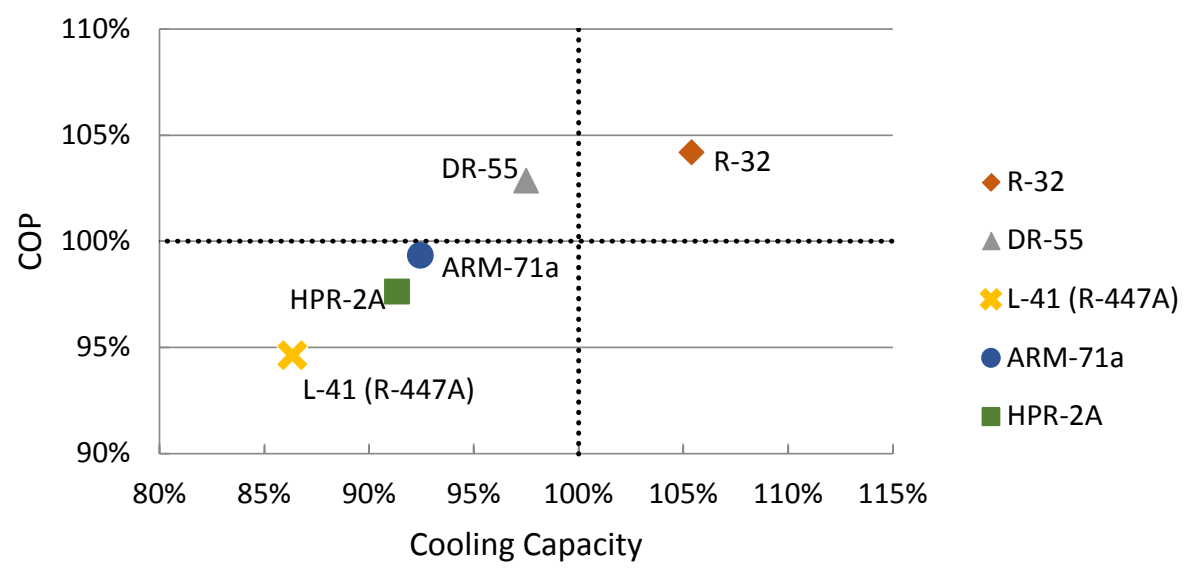

Figure 18. Performance of alternative refrigerants compared with R-410A at AHRI A test conditions (outdoor temperature $35^{\circ} \mathrm{C}$ and indoor temperature $27^{\circ} \mathrm{C}$ ).

Figure 19 compares the COP and cooling capacity of the alternative refrigerants to that of R-410A under the ISO T3 test conditions. Under the ISO T3 test conditions, where the outdoor temperature is $11^{\circ} \mathrm{C}$ higher than under the AHRI A conditions, HPR-2A and R-32 led to 3\% and 4\% higher COPs than the baseline, respectively. The other alternatives approximately matched the COP of the baseline. In terms of cooling capacity, R-32 resulted in 9\% better performance than the baseline, and DR-55 and HPR-2A were within $4 \%$ of the baseline. ARM-71a and R-447A led to within $7 \%$ and $9 \%$ of the cooling capacity of the baseline, respectively. 
Performance Relative to Baseline at ISO T3 Conditions $46^{\circ} \mathrm{C}\left[114.8^{\circ} \mathrm{F}\right]$ Outdoor and $29^{\circ} \mathrm{C}\left[84.2^{\circ} \mathrm{F}\right]$ Indoor

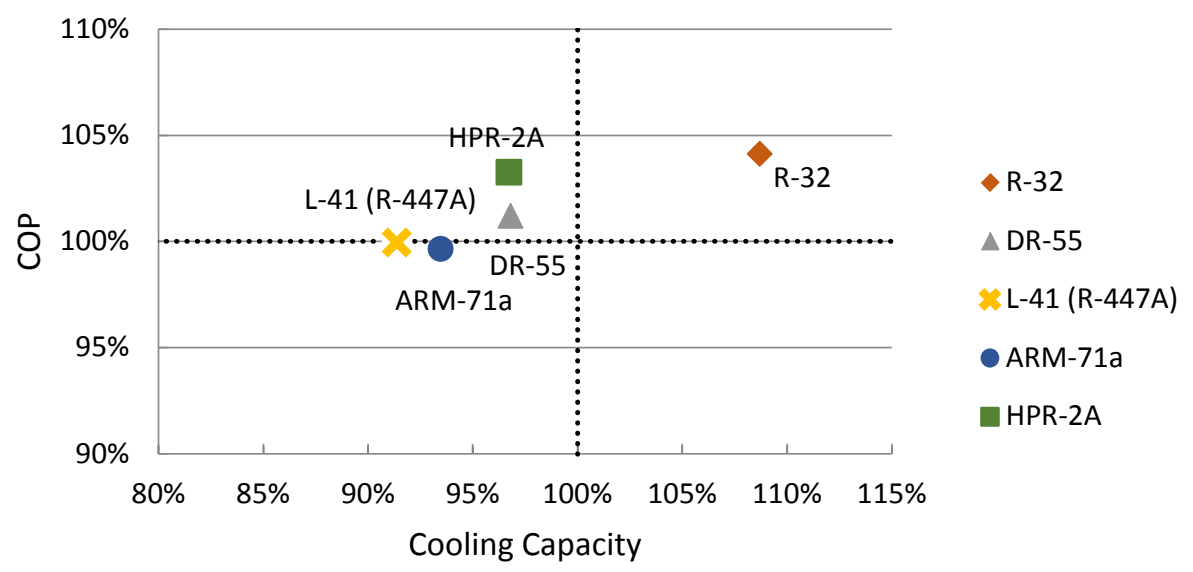

Figure 19. Performance of alternative refrigerants compared with R-410A at ISO T3 (outdoor temperature $46^{\circ} \mathrm{C}$ and indoor temperature $29^{\circ} \mathrm{C}$ ).

Figure 20 compares the COP and cooling capacity of the alternative refrigerants to that of R-410A under Hot test conditions. Under Hot test conditions, all the alternatives saw improvement compared with the baseline, and all of them resulted in higher COPs than the baseline. DR-55 and R-32 led to higher performance than the baseline in terms of both COP and capacity, with R-32 resulting in 11\% higher capacity and 5\% higher COP compared with the baseline.

Performance Relative to Baseline at Hot Conditions $52^{\circ} \mathrm{C}\left[125.6^{\circ} \mathrm{F}\right]$ Outdoor and $29^{\circ} \mathrm{C}\left[84.2^{\circ} \mathrm{F}\right]$ Indoor

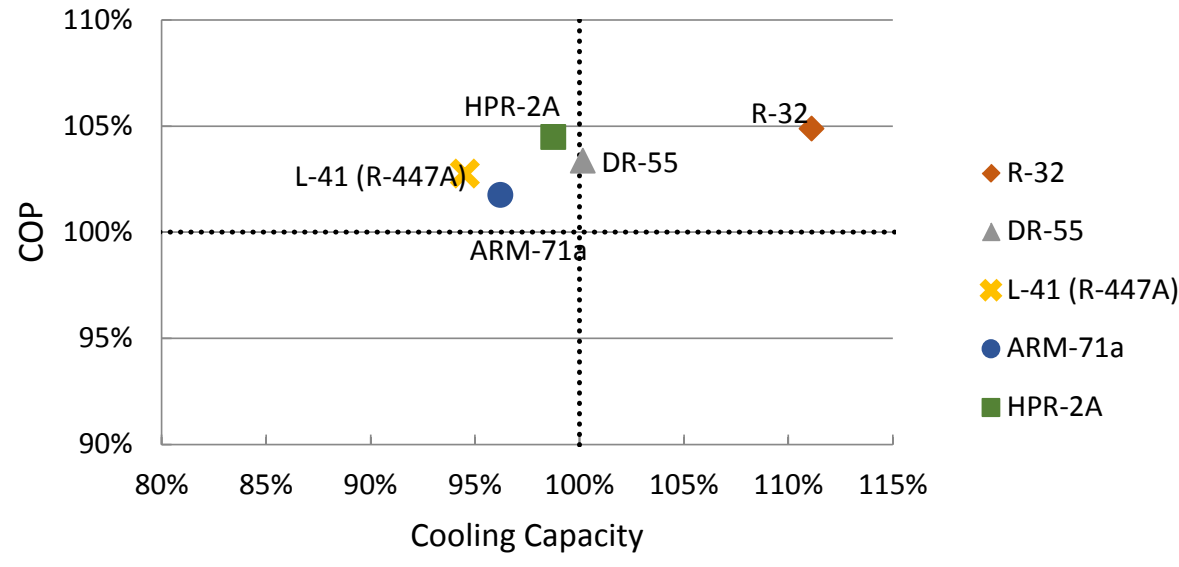

Figure 20. Performance of alternative refrigerants compared with R-410A at Hot test conditions (outdoor temperature $52^{\circ} \mathrm{C}$ and indoor temperature $29^{\circ} \mathrm{C}$ ).

Figure 21 shows the COP and cooling capacity of the alternative refrigerants compared with that of R410A under Extreme test conditions. All alternatives resulted in at least $96 \%$ of the cooling capacity of the baseline. DR-55 and HPR-2A matched the cooling capacity of the baseline and led to 3\% and 6\% 
higher COPs than the baseline, respectively. There was little change for R-447A, ARM-71a, and R-32 compared with the results under Hot test conditions.

\section{Performance Relative to Baseline at Extreme Conditions $55^{\circ} \mathrm{C}\left[131^{\circ} \mathrm{F}\right]$ Outdoor and $29^{\circ} \mathrm{C}\left[84.2^{\circ} \mathrm{F}\right]$ Indoor}

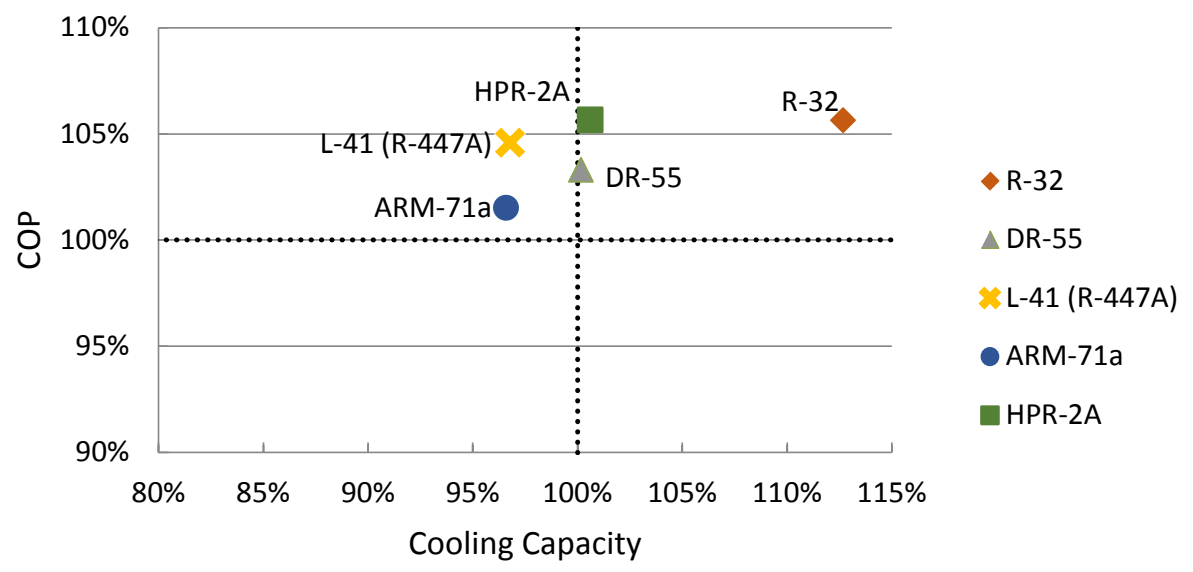

Figure 21. Performance of alternative refrigerants compared with R-410A at Extreme test conditions (outdoor temperature $55^{\circ} \mathrm{C}$ and indoor temperature $29^{\circ} \mathrm{C}$ ).

Figure 22 shows the difference between the compressor discharge temperatures of each refrigerant compared with the baseline, at each test condition. Temperatures up to $5^{\circ} \mathrm{C}$ above the baseline are considered acceptable, whereas temperatures above that may require further engineering to avoid compressor reliability issues and issues with lubricant breakdown. The compressor discharge temperature was higher than the baseline for all alternative refrigerants, indicating the possible need for further engineering for reliable operation with the alternative refrigerants.

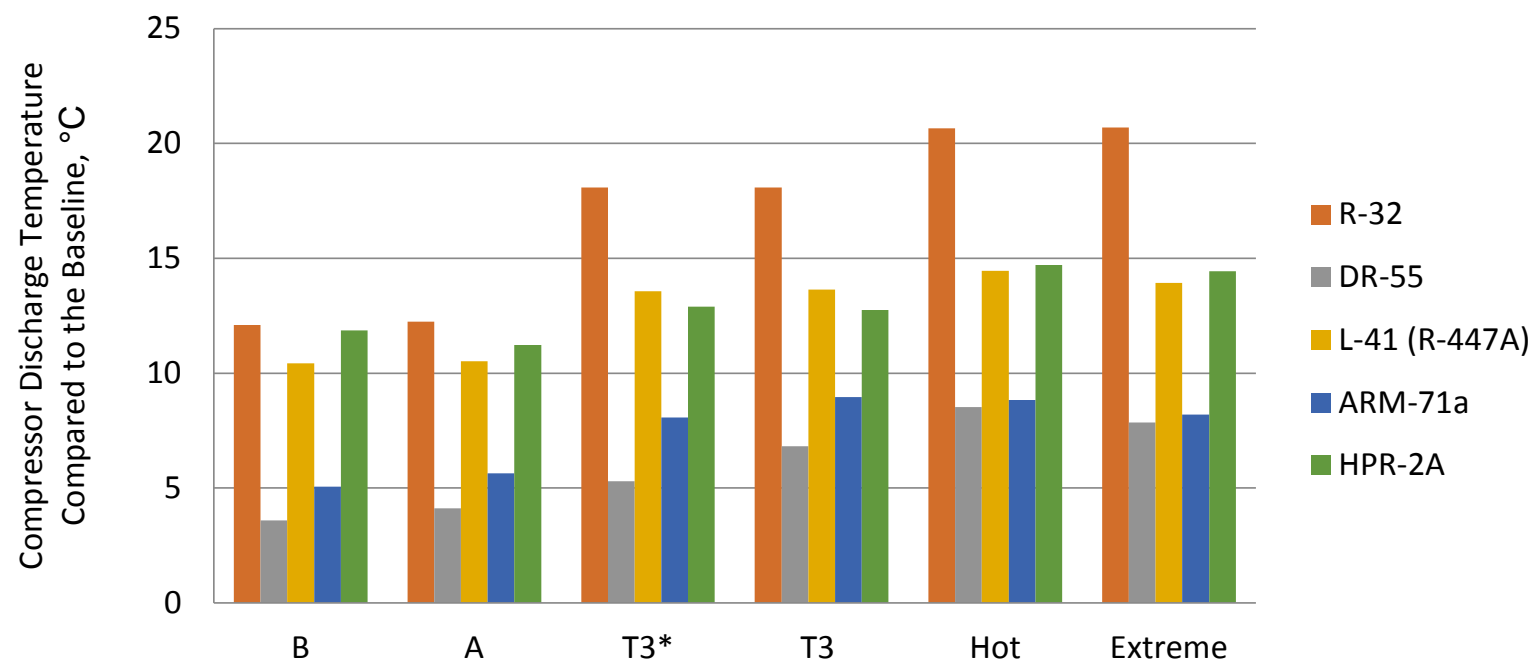

Figure 22. Compressor discharge temperature of the alternative refrigerants, difference compared with the baseline. 


\subsubsection{Performance by Refrigerant}

Figure 23 shows the performance of R-32 compared with that of the baseline (R-410A) at each test condition. The performance of R-32 relative to the baseline improved with increases in ambient temperature, in terms of both COP and cooling capacity. At the AHRI B test condition, R-32 resulted in 2\% higher cooling capacity and 1\% higher COP; and at Extreme test conditions, it resulted in 13\% higher cooling capacity and $6 \%$ higher COP, all relative to the baseline.

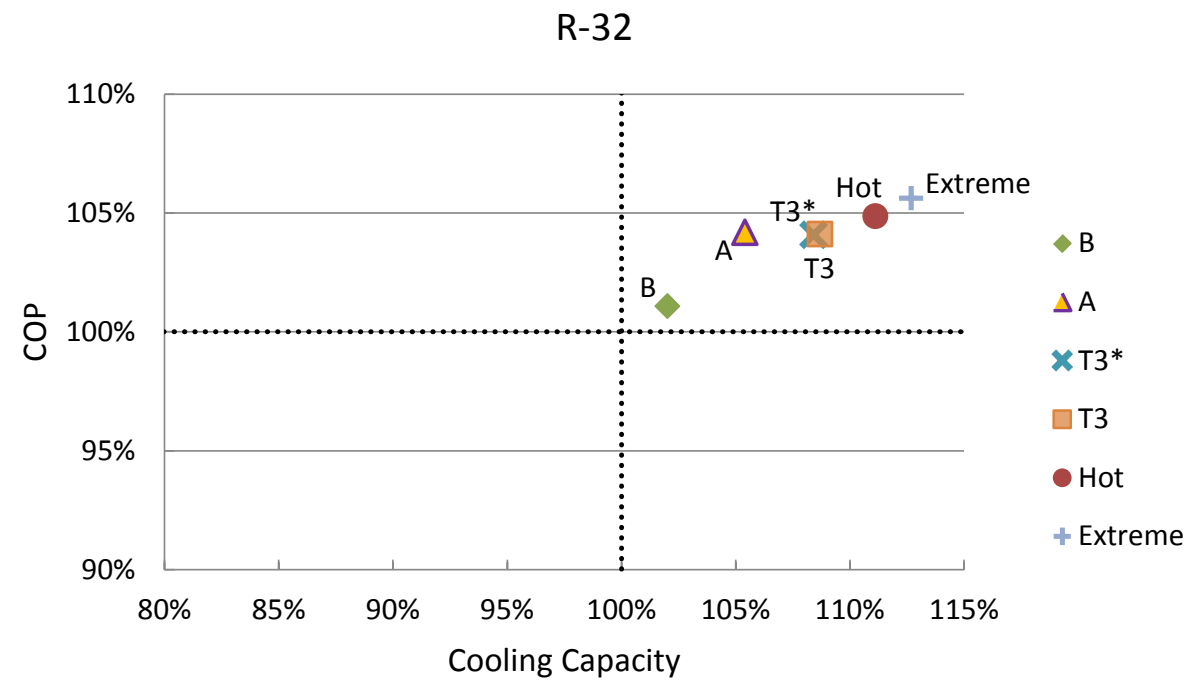

Figure 23. Performance of R-32 compared with R-410A at each test condition.

Figure 24 shows the performance of DR-55 compared with that of the baseline (R-410A) at each test condition. In general, DR-55 led to higher relative cooling capacity at higher ambient temperatures, even bettering the baseline at the T3*, Hot and Extreme test conditions. However, the difference is within the uncertainty of the results. DR-55 resulted in higher COP than the baseline at all test conditions, but the results are not significantly higher when accounting for uncertainty.

\section{DR-55}

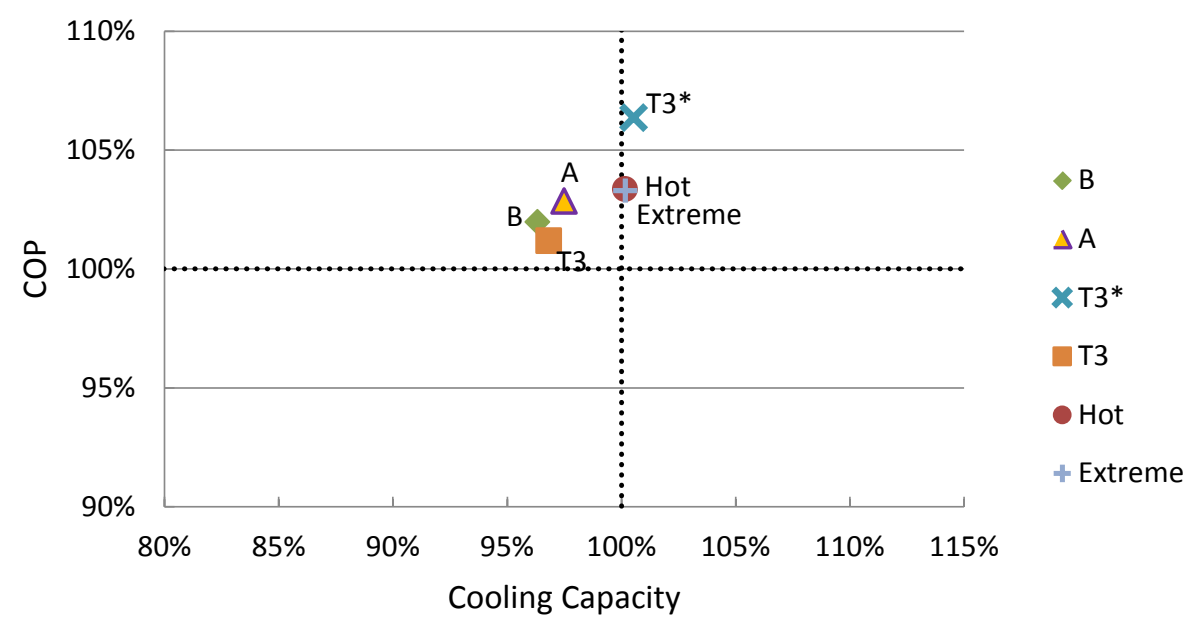

Figure 24. Performance of DR-55 compared with R-410A at each test condition. 
Figure 25 shows the performance of HPR-2A compared with the baseline (R-410A) at each test condition. The system performance using HPR-2A showed relative improvement over the baseline as the ambient temperature increased, in terms of both COP and cooling capacity. At the AHRI B test condition, HPR-2A led to $12 \%$ lower cooling capacity and $7 \%$ lower COP compared with the baseline; whereas at Extreme test conditions, HPR-2A matched the cooling capacity of the baseline and bettered its COP by $6 \%$.

HPR-2A

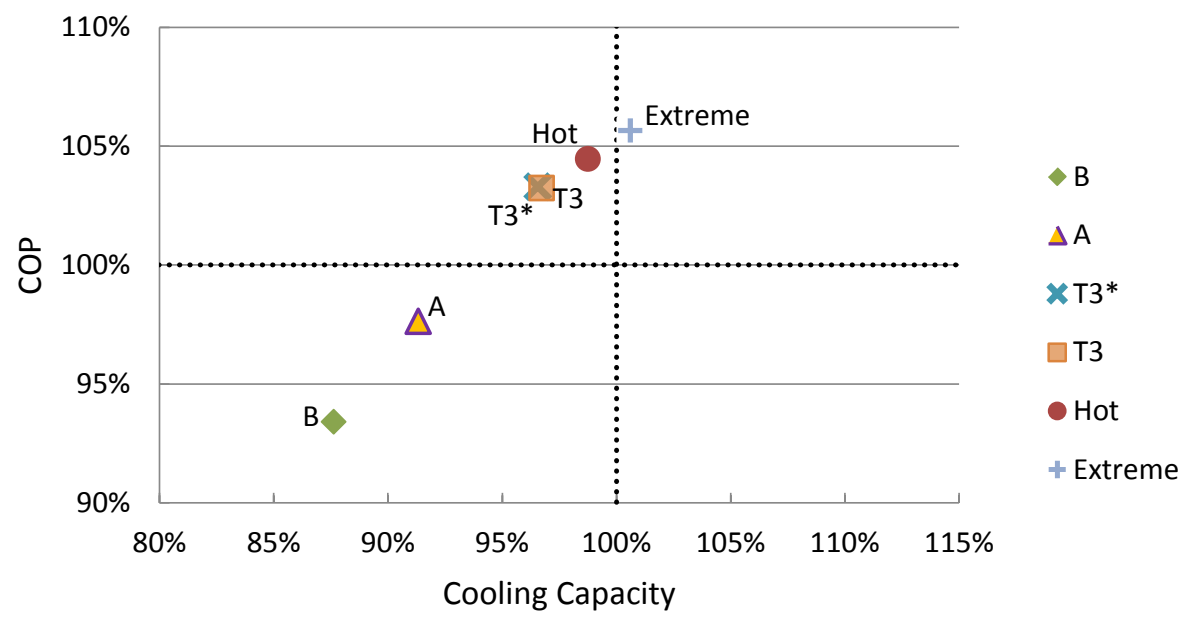

Figure 25. Performance of HPR-2A compared with R-410A at each test condition.

See APPENDIX E for additional results, including detailed data tables.

The re-test of the unit using R-410A at the end of the testing (results shown in APPENDIX E) showed the unit performed within $-2.4 \%$ of the cooling capacity and $-2.1 \%$ of the COP. These results suggest that the extended testing with all the alternative refrigerants resulted in minimal performance degradation and that the system reliability was not affected by the use of the alternative refrigerants.

\subsection{ERROR ANALYSIS}

\subsubsection{Uncertainty Analysis}

The experimental uncertainty was calculated based on the uncertainties of each of the measured variables that are propagated into the value of the calculated quantity. The method for determining this uncertainty propagation is described in NIST Technical Note 1297. [16] Assuming the individual measurements are uncorrelated and random, the uncertainty in the calculated quantity can be determined as

$$
U_{Y}=\sqrt{\sum_{i}\left(\frac{\partial Y}{\partial X_{i}}\right)^{2} U_{X_{i}}^{2}}
$$

where $Y$ is the calculated quantity, $X_{i}$ is the measured variable and $U_{x i}$ is the uncertainty in the measured variable.

Based on the uncertainty analysis using the instrument accuracies listed in Table C.1, the R-22 unit airside capacity and COP measurement uncertainties are $\pm 2.3 \%$ and $\pm 2.4 \%$ respectively. The R-410A unit was instrumented with higher-performance (Class A) resistance temperature detectors compared with the 
thermocouples, as shown in Table C.2. Therefore, the corresponding capacity and COP measurement uncertainties are \pm 1.5 and $\pm 1.6 \%$, respectively.

\subsubsection{Energy Balance}

ANSI/ASHRAE Standard 37 requires that the cooling capacity be evaluated using a secondary approach to the air side in order to establish the required confidence level in the measurement. In this work, the secondary cooling capacity was measured using the refrigerant enthalpy method. The air side and the refrigerant side measured cooling capacities are compared to establish trustworthy results by analyzing the energy balance of the system. ${ }^{*}$ The air-side cooling capacity was evaluated using the air enthalpy method. The refrigerant-side capacity was evaluated using refrigerant mass flow measurements and thermodynamic property evaluation, using appropriate independent measured properties (e.g., singlephase temperature and pressure). It was important to establish a proper energy balance using the baseline refrigerants because, for these refrigerants, the thermodynamic property evaluations are established and well characterized. Table 15 shows the energy balance for the R-22 unit at the AHRI A conditions for the baseline and alternative refrigerants. Note that the energy balance is within the measurement uncertainties in most of the test runs shown in Table 15.

Table 15. Energy balance for the R-22 unit at the AHRI A conditions

\begin{tabular}{|r|c|}
\hline \multicolumn{1}{|l|}{ Refrigerant } & Energy balance \\
\hline $\mathrm{R}-22$, mineral oil & $1.50 \%$ \\
$\mathrm{R}-444 \mathrm{~B}$ & $-1.38 \%$ \\
$\mathrm{DR}-3$ & $-2.30 \%$ \\
$\mathrm{~N}-20 \mathrm{~B}$ & $0.68 \%$ \\
$\mathrm{ARM}-20 \mathrm{~B}$ & $1.52 \%$ \\
$\mathrm{R}-290, \mathrm{POE}$ & 1.39 \\
$\mathrm{R}-290$, mineral oil & $1.53 \%$ \\
$\mathrm{R}-22$, POE oil & $2.12 \%$ \\
$\mathrm{R}-22$, mineral oil rerun & $2.89 \%$ \\
\hline
\end{tabular}

Table 16 shows the energy balance for the R-410A unit at the AHRI A conditions for the baseline and alternative refrigerants. Note that the energy balance is within the measurement uncertainties in most of the test runs shown in Table 16.

Table 16. Energy balance for the R-410A unit at the AHRI A conditions

\begin{tabular}{|c|c|}
\hline Refrigerant & Energy balance \\
\hline $\mathrm{R}-410 \mathrm{~A}$ & $0.05 \%$ \\
\hline $\mathrm{R}-32$ & $-0.69 \%$ \\
\hline DR -55 & $-1.93 \%$ \\
\hline L-41 (R-447A) & $-3.61 \%$ \\
\hline ARM-71A & $-1.83 \%$ \\
\hline HPR-2A & $-1.52 \%$ \\
\hline $\mathrm{R}-410 \mathrm{~A}$ rerun & $-0.98 \%$ \\
\hline
\end{tabular}

\footnotetext{
* The energy balance is defined as the difference between the refrigerant-side cooling capacity and the air-side cooling capacity, divided by the air-side cooling capacity.
} 


\section{CONCLUSIONS}

This report documents the performance evaluation of two mini-split air-conditioning units designed to operate in high-ambient-temperature environments. The first unit is designed for R-22 refrigerant with a rated COP of 2.78 (EER of 9.5), and the second unit is designed for R-410A refrigerant with a rated COP of 3.37 (EER of 11.5). Both units have cooling capacities of $5.25 \mathrm{~kW}_{\text {th }}$ (1.5 TR). The experimental facility followed the ANSI/ASHRAE Standard 37 and exhibited air-side capacity and COP measurement uncertainties of $\pm 2.3 \%$ and $\pm 2.4 \%$, respectively, for the R-22 unit and of \pm 1.5 and $\pm 1.6 \%$, respectively, for the R-410A unit. As expected, under all testing conditions, the performance of the units degraded as the outdoor temperature increased.

The R-22 alternative refrigerants showed promising results: although both of the A1 alternative refrigerants lagged in performance, some of the A2L refrigerants showed capacity within $5 \%$ and efficiency within approximately $10 \%$ of the baseline system. The A3 refrigerant (R-290) exhibited higher efficiency consistently; however, it did not match the cooling capacity of the baseline system. The most promising A2L refrigerants exhibited slightly higher compressor discharge temperatures, whereas propane exhibited lower compressor discharge temperatures.

The R-410A alternative refrigerants are all in the A2L safety category. They showed significant potential as replacements. R-32 showed consistently better capacity and efficiency; however, R-32 resulted in compressor discharge temperatures that were $12-21^{\circ} \mathrm{C}$ higher than those using the baseline refrigerant, which may negatively impact compressor reliability. DR-55 had consistently higher COPs than the baseline and matched its capacity at higher ambient conditions, with compressor discharge temperatures 3.6-8.5 ${ }^{\circ} \mathrm{C}$ higher than the baseline. HPR-2A's performance relative to the baseline improved at higher ambient temperatures and exceeded its COP at all ambient temperatures higher than $35^{\circ} \mathrm{C}$. R-447A and ARM-71a had consistently lower capacity than the baseline. The system efficiency of R-447A consistently improved as the ambient temperature increased, surpassing the baseline efficiency for tested ambient temperatures higher than $46^{\circ} \mathrm{C}$. For ARM-71a, the efficiency was similar to that of the baseline at all test conditions.

The efficiency and capacity of the alternative refrigerants would be expected to improve through design modifications that manufacturers would conduct before introducing a new product to market. However, given that the scope of this study covered only soft-optimized testing, no detailed assessment can be made as to the extent of potential improvements through design changes. Within the bounds of what is possible with regard to optimization for soft-optimized tests, the ORNL test plan included only minor optimizations, including refrigerant charge, capillary tube length, and lubricant change. That likely indicates that the data presented in this report are conservative results that could improve through further optimization. Additional optimization, including heat transfer circuiting and proper compressor sizing and selection, would likely yield better performance results for all of the alternative refrigerants.

Losses in cooling capacity are typically easier to recover through engineering optimization than are losses in COP. The primary practical limit to improvements in capacity is the physical size of the unit; but that is not expected to be a significant concern in this case, based on the magnitude of the capacity losses exhibited in this evaluation program, where such losses were observed. Thus, the COP losses and the increases in compressor discharge temperature are particularly important results of this testing program, in that these variables will be the primary focus of future optimization efforts.

This performance evaluation shows that viable replacements exist for both R-22 and R-410A at high ambient temperatures. Multiple alternatives for R-22 performed well, and most R-410A alternatives matched or exceeded the performance of R-410A. these may be considered as prime candidate lower GWP refrigerants for high-ambient-temperature environments. Before commercialization, engineering 
optimization by manufacturers can address performance loss, the increase in compressor discharge temperature that many alternatives exhibited (particularly the R-410A alternatives), and any safety concerns associated with flammable alternatives. 


\section{REFERENCES}

[1] Climate Change 2007: The Physical Science Basis. Contribution of Working Group I to the Fourth Assessment Report of the Intergovernmental Panel on Climate Change (2007). S. Solomon, D. Qin, M. Manning, Z. Chen, M. Marquis, K. B. Averyt, M. Tignor, and H. L. Miller, eds. Cambridge University Press, Cambridge, United Kingdom, and New York, NY, USA; Section 2.10.2: Direct Global Warming Potentials. 2013.Available at https://www.ipcc.ch/publications and data/ar4/wg1/en/contents.html. Accessed October 2015.

[2] G. Myhre, D. Shindell, F.-M. Bréon, W. Collins, J. Fuglestvedt, J. Huang, D. Koch, J.-F. Lamarque, D. Lee, B. Mendoza, T. Nakajima, A. Robock, G. Stephens, T. Takemura, and H. Zhang (2013). “Anthropogenic and Natural Radiative Forcing,” in Climate Change 2013: The Physical Science Basis. Contribution of Working Group I to the Fifth Assessment Report of the Intergovernmental Panel on Climate Change. T. F. Stocker, D. Qin, G.-K. Plattner, M. Tignor, S. K. Allen, J. Boschung, A. Nauels, Y. Xia, V. Bex and P. M. Midgley, eds. Cambridge University Press, Cambridge, United Kingdom, and New York, NY, USA. Available at https://www.ipcc.ch/pdf/assessmentreport/ar5/wg1/WG1AR5_Chapter08_FINAL.pdf. Accessed October 2015.

[3] Y. Xu, D. Zaelke, G.J.M. Velders, and V. Ramanathan (2013). “The Role of HFCs in Mitigating 21st Century Climate Change,” Atmos. Chem. Phys. 13, 6083-6089. See also B. Hare et al. (2012). Closing the 2020 Emissions Gap: Issues, Options And Strategies, Climate Analytics; and V. Ramanathan and Y. Xu (2010). "The Copenhagen Accord for Limiting Global Warming: Criteria, Constraints, and Available Avenues,” Proc. Natl. Acad. Sci. USA 107, 8055-8062.

[4] UNEP (2015), “Additional Information on Alternatives to Ozone-Depleting Substances,” Montreal Protocol on Substances that Deplete the Ozone Layer, Report of the Technology and Economic Assessment Panel, Decision XXVI/9 Task Force Report, Volume 3, June 2015. Available at http://bit.ly/1NjpOSu. Accessed October 2015.

[5] A. El-Talouny and O. Nielsen (2014). "Promoting Low-GWP Refrigerants for Air-Conditioning Sectors in High-Ambient Temperature Countries (PRAHA).” OzonAction Fact Sheet, United Nations Environment Programme and United Nations Industrial Development Organization, November. Available at http://bit.ly/1LfRgOS . Accessed October 2015.

[6] Air-Conditioning, Heating, and Refrigeration Institute (2015). Participants' Handbook: AHRI LowGWP Alternative Refrigerants Evaluation Program (Low-GWP AREP). AHRI, Arlington, Virginia, April 17. Available at http://www.ahrinet.org/App_Content/ahri/files/RESEARCH/Participants_Handbook2015-04-17.pdf. Accessed October 2015.

[7] C. K. Rice, V. D. Baxter, S. A. Hern, T. P. McDowell, J. D. Munk, and B. Shen (2013). "Development of a Residential Ground-Source Integrated Heat Pump,” ASHRAE Transactions 119(1), Special Section p. 1.

[8] V. D. Baxter, J. J. Tomlinson, R. W. Murphy, B. G. Ashdown, and M. V. Lapsa (2005). "Residential Heat Pump Water Heater (HPWH) Development Status-USA," in Proceedings of 8th International Energy Agency Heat Pump Conference, Las Vegas, Nevada.

[9] J. Wolfe and G. Irby (ND). "Successful CFC Phaseout Project.” Oak Ridge National Laboratory. Available at http://homer.ornl.gov/sesa/environment/ods/ornl.pdf

[10] S. Fischer, J. Sand, and V. Baxter (1997). Global Warming Impacts of Ozone-Safe Refrigerants and Refrigeration, Heating, and Air-Conditioning Technologies. ORNL/CP-95275; CONF-971151-ON, 
Oak Ridge National Laboratory. Available at http://www.osti.gov/scitech/biblio/555370. Accessed October 2015.

[11] O. Abdelaziz, B. Fricke, and E. Vineyard (2012). "Development of Low Global Warming Potential Refrigerant Solutions for Commercial Refrigeration Systems using a Life Cycle Climate Performance Design Tool,” International Refrigeration and Air Conditioning Conference, Paper 1353, Purdue University, July 16-19, 2012. Available at http://docs.lib.purdue.edu/cgi/viewcontent.cgi?article=2352\&context=iracc. Accessed October 2015.

[12] J. Sand, S. Fischer, and V. Baxter (1997). Energy and Global Warming Impacts of HFC Refrigerants and Emerging Technologies, US Department of Energy Alternative Fluorocarbons Environmental Acceptability Study. Available at http://web.ornl.gov/sci/ees/etsd/btric/eere_research_reports/electrically_driven_heat_pumps/fluids_de velopment/cfc and hcfc replacements/tewi 3/tewi 3.pdf. Accessed October 2015.

[13] ASHRAE Refrigeration Handbook (2014). "Refrigerant Control Devices, Section Adiabatic Capillary Tube Selection Procedure,” chapter 11, ASHRAE, Atlanta, Georgia. For details, see Adiabatic Capillary Tube Performance with Alternative Refrigerants (1995). ASHRAE Research Project RP762, ERI-95413, D. A. Wolfe, R. R. Bittle, M. B. Pate, eds. Iowa State University.

[14] Air-Conditioning, Heating, and Refrigeration Institute (2015). Participants' Handbook: AHRI LowGWP Alternative Refrigerants Evaluation Program (Low-GWP AREP). AHRI, Arlington, Virginia, April 17, pp 24-25. Available at http://www.ahrinet.org/App_Content/ahri/files/RESEARCH/Participants_Handbook2015-04-17.pdf. Accessed October 2015.

[15] B. N. Taylor and C. E. Kuyatt (1994). Guidelines for Evaluating and Expressing the Uncertainty of NIST Measurement Results, National Institute of Standards and Technology Technical Note 1297.

[16] X. Wang and K. Amrane (2014). “AHRI Low Global Warming Potential Alternative Refrigerants Evaluation Program (Low-GWP AREP)—Summary of Phase I Testing Results,” International Refrigeration and Air Conditioning Conference, Paper 1416, Purdue University, July 14-17, 2014. Available at http://docs.lib.purdue.edu/cgi/viewcontent.cgi?article=2415\&context=iracc. Accessed October 2015. 
APPENDIX A. EXPERT PANEL-BIOGRAPHIES 



\section{APPENDIX A. EXPERT PANEL-BIOGRAPHIES}

Brief biographies of the panel members are included below.

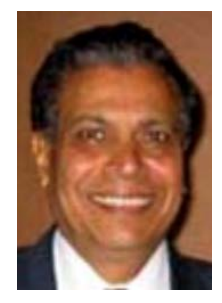

\section{Dr. Radhey Agarwal (India)}

Radhey Agarwal is a mechanical engineer. He received his $\mathrm{PhD}$ from the Indian Institute of Technology in Delhi (India) in 1975. He specializes in refrigeration, air-conditioning, and alternative refrigerants to CFCs and HCFCs. He is a former Deputy Director (faculty), Dean of Industrial Research and Development and Chairman, Department of Mechanical Engineering, at IIT Delhi. He was the Co-Chair of the UNEP Technical Options Committee on Refrigeration, Air-conditioning and Heat Pumps (RTOC) and a member of the Technology and Economics Assessment Panel (1996-2008) of the Montreal Protocol. He has been actively contributing toward efforts to protect the ozone layer as part of the Technology and Economics Assessment Panel (UNEP TEAP) since 1989. He is the recipient of the 1998 US Environmental Protection Agency (EPA) Stratospheric Ozone Protection Award for Technical Leadership in CFC-Free Refrigeration and the 2007 US EPA Stratospheric Ozone Protection Award Best of the BEST. Dr. Agarwal was the Vice-President of the International Institute of Refrigeration (IIR), Commission-B2, and a member of the scientific committee of the IIR. He is a member of the American Society of Heating, Refrigerating and Air-Conditioning Engineers (ASHRAE) and the Indian Society of Heating, Refrigerating and Air-Conditioning Engineers (ISHRAE).

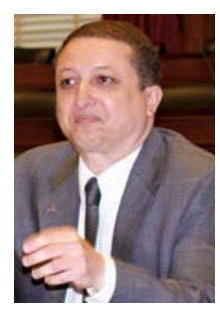

\section{Dr. Karim Amrane (USA)}

Karim Amrane is Senior Vice President of Regulatory and International Policy at the AirConditioning, Heating, and Refrigeration Institute (AHRI). He manages the industry's cooperative research program and is responsible for the development and implementation of AHRI's regulatory and international policy. He holds a $\mathrm{PhD}$ in mechanical engineering from the University of Maryland at College Park (Maryland, USA) where he currently is a part-time faculty member. Dr. Amrane has over 25 years of experience in the air-conditioning and refrigeration industry. He is a member of ASHRAE, the International Institute of Refrigeration, and the American Society of Mechanical Engineers.

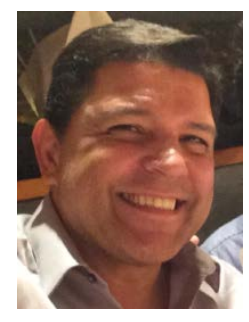

\section{Dr. Enio Bandarra (Brazil)}

Enio P. Bandarra Filho is an associate professor of mechanical engineering from the Federal University of Uberlandia (Brazil). He received his BS from the State University of Sao Paulo (Brazil) in 1994, and his MS and PhD from the University of Sao Paulo, in thermal sciences, in 1997 and 2002, respectively. In 2007-2008 he was a visiting professor in the heat and mass transfer laboratory at the Ecole Polytechnique Federale de Lausanne, Switzerland, working with oil-refrigerant mixtures in two-phase flow. Currently, he has one postdoc, eight $\mathrm{PhD}$, and four MS students in different areas, such as refrigeration and air-conditioning, heat transfer of nanofluids, heat exchangers, single-phase flow, control in refrigeration systems, and related topics. He has published more than 260 journal articles, book chapters, and conference papers and has won awards for best-presented papers. 


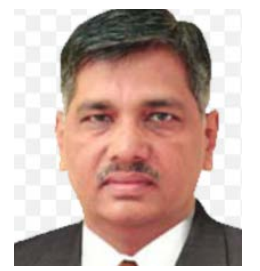

\section{Dr. J. Bhambure (India)}

Jitendra Bhambure, who is presently the Executive Vice President-R\&D and Technology, at Blue Star, received a degree in electrical engineering in 1979 from Bombay University (India) and a post-graduate degree in management studies from Mumbai University (India) in 1983. He joined Rallis India Ltd. in 1979 as a trainee engineer and worked there for 13 years. He was head of R\&D before he left Rallis India. He joined Blue Star in 1992 and worked in various operations before taking charge of R\&D in 2000. He has trained in the United States, London Business School, IIM-A’bad, and at Tel Aviv University. Dr. Bhambure was the founder and President of ISHRAE Thane Sub Chapter, which over the course of 3 years has become an independent chapter. He is a member of the Indian Society of Heating, Refrigerating and AirConditioning Engineers (ISHRAE) Technical Committee and an active member of the Refrigeration and Air-Conditioning Manufacturers Association (RAMA) representing industry on energy efficiency and new refrigerants with the Bureau of Energy Efficiency, Bureau of Indian Standards, and on ozone cells under the Ministry of Environment and Forest. He is also the Chairperson of the ozone-depleting substances committee of RAMA.

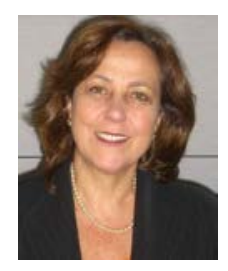

\section{Dr. Suely Machado Carvalho (co-chair; Brazil)}

Suely Carvalho is a physicist and received her $\mathrm{PhD}$ from Purdue University (USA). She was a postdoctoral researcher at the National Superconducting Cyclotron Laboratory (NSCL), Department of Energy (DOE), at Michigan State University, East Lansing, USA (1980). As former director of the Montreal Protocol Unit and Principal Technical Adviser for Chemicals for the United Nations Development Programme in New York (2002-2013), she led the implementation of projects in more than 100 developing countries to replace ozone-depleting substances in several sectors. She was the UNEP Technology and Economics Assessment Panel co-chair for 10 years. As the former director of Technology Transfer at the São Paulo State Environment Protection Agency, CETESB (1985-1987), she established the Climate and Ozone Protection programs at the state level. She has been involved with the Montreal Protocol nationally and internationally for 25 years. Dr. Carvalho is currently adviser to the Superintendent at the Instituto de Pesquisas Energéticas e Nucleares, IPEN-CNEN, Ministry of Science, Technology and Innovation, MCTI, São Paulo, Brazil.

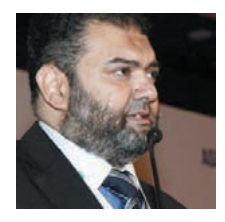

\section{Mr. Ayman El-Talouny (UNEP)}

Mr. Eltalouny holds a mechanical engineering degree from Cairo University and specializes in the field of refrigeration and air-conditioning. Before joining the United Nations (UN), he spent 10 years in the refrigeration industry and 4 years as Technical Advisor for the Egyptian Environmental Affairs Agency (EEAA) for the implementation of the Montreal Protocol. He has 20 years of experience with the Montreal Protocol at the industry, government and UN levels. Mr. Eltalouny joined the United Nations Environment Programme (UNEP) in 2003 and is currently responsible for the implementation of phaseout plans of ozone-depleting substances in the West Asia region. He is currently co-managing the UNEP-UN Industrial Development Organization PRAHA and EGYPRA projects for assessing low-GWP alternative refrigerants. Mr. Eltalouny is also a founding member and past president of the Bahrain ASHRAE Chapter and coordinator to the UNEP-ASHRAE and UNEP-AHRI partnerships, as well as a member of the drafting committees of the Arab and Egyptian Codes of refrigeration and air-conditioning. 


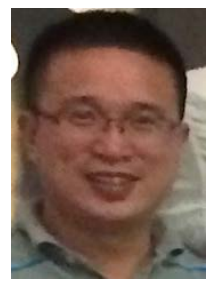

\section{Dr. Tingxun Li (China)}

Tingxun Li received his PhD from Shanghai Jiaotong University (China). He has been engaged in alternative refrigerant activities since 1995. As an associate professor at Sun Yat-sen University, he teaches courses in refrigeration and conducts research on airconditioning and cryogenics. He led the conversion from R-22-based to propane-based room air-conditioner manufacturing at Guangdong Midea Group in a demonstration project that was funded by the Multilateral Fund of the Montreal Protocol. As a member of the Refrigeration and Air-Conditioning Technical Options Committee (RTOC) of the United Nations Environment Programme, he is one of the authors of the 2014 RTOC report and the report of the task force. He is also a member of IEC SC61D and has been engaged in a revision of the standard IEC 60335-2-40 since 2013.

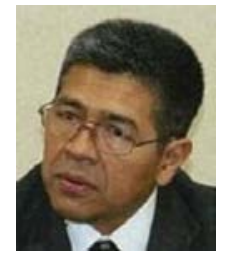

\section{Dr. Samuel Yana Motta (Peru)}

Samuel F. Yana Motta received his BS degree from the National Engineering University in his native Peru, and his PhD from the Catholic University (Brazil), all in mechanical engineering. Following a guest researcher appointment at the National Institute of

Standards (Thermal Machinery Group-Gaithersburg, MD, USA), he joined Honeywell as a scientist in the Buffalo Research Laboratory in 2000. At Honeywell, he participated in the development of new environmentally friendly refrigerants such as HFO-1234yf and HFO-1234ze. He has also assumed positions of increasing responsibility and leadership in the development of such fluids. He now leads the Global R\&D teams responsible for developing new heat transfer fluids.

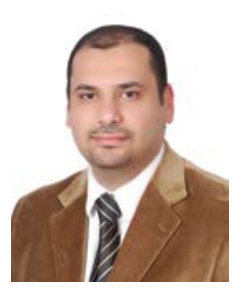

\section{Mr. Maher Mousa (Saudi Arabia)}

Maher Mousa is currently an independent consultant in HVACR industry and environmental policy, offering consultancy services to both the private and public sectors. He has been the Director of Product Development and Regulations for United Technologies BIS, Middle East/Carrier Middle East from May 2013 until June 2015. He also had the lead role in managing the laboratories and testing services at Carrier Middle East with the objective of complying with international quality standards and laboratories accreditations. He is currently based in Jeddah, Saudi Arabia.

He started his career with Carrier Corporation in 2002. In 2011, he was working as the Product Development Manager. He led technology transfer and development of high-efficiency products with alternative refrigerants for high-ambient applications in the Middle East. Before that, he held several positions of increasing responsibility related to engineering and marketing. He is serving as a government advisor for energy and environmental regulations. He has contributed to the development of minimum energy efficiency regulations in Saudi Arabia and the United Arab Emirates. In 2013, Maher was an industry representative providing technical advice to the regulatory authorities in KSA on Montreal Protocol implementation and its impacts on the local HVAC industry. Currently, Maher Mousa is a member of the Refrigeration and Air-Conditioning Technical Options Committee of the United Nations Environment Programme under the Montreal Protocol, nominated by the Kingdom of Saudi Arabia.

He has a Bachelor's degree and higher diploma in mechanical engineering from King Abdul Aziz University, Saudi Arabia, and is in the process of completing an MBA from Leicester University, United Kingdom. 


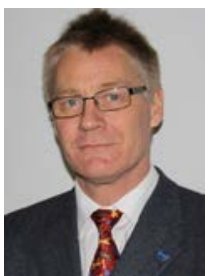

\section{Mr. Ole Nielsen (UNIDO)}

Mr. Nielsen graduated from the Technical University of Copenhagen (Denmark) in 1988 as a mechanical engineer specializing in energetics and refrigeration. He worked in the Danish refrigeration industry until 1996. Afterward, he worked as an independent technical consultant on Montreal Protocol project formulation and implementation until 2003. He then returned to the private sector as sales manager for refrigeration equipment. He joined the United Nations Industrial Development Organization Montreal Protocol team in 2011. Currently he is acting as Chief of the Montreal Protocol Unit. Mr. Nielsen has been involved with the Montreal Protocol since 1993 through consultancy, the private sector, and most recently through an implementing agency, with a specialty in the refrigeration and air-conditioning sectors.

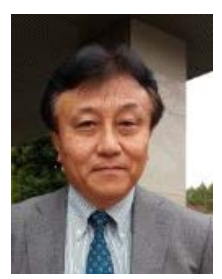

\section{Mr. Tetsuji Okada (Japan)}

Tetsuji Okada received his BS degree from the University of Tokyo (Japan) and his MS degree from the University of California, Berkeley (USA), all in mechanical engineering. He joined Mitsubishi Electric Corporation in 1980. He was engaged in the design of domestic air conditioners and the development of finned tubed-type heat exchangers until 1995. From 1995 to 1998 he researched radiation air conditioning in the company's laboratory. He was the department manager of heat pump hot water heater development using $\mathrm{CO}_{2}$ refrigerant from 2000 to 2009. He was transferred to the commercial air-conditioner factory in Scotland as the vice president (2010-2012). Mr. Okada was the general manager of the Brussels office of Mitsubishi Electric Europe from 2012-2014 and is now the president of the Japan Refrigeration and Air Conditioner Industry Association.

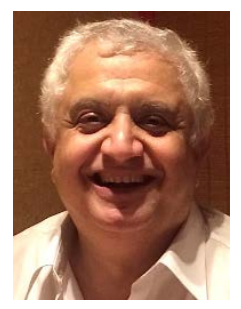

\section{Dr. Alaa Olama (Egypt)}

Alaa Olama received his M.Sc. and PhD from King's College, London University (England), in mechanical engineering, specializing in refrigeration and air-conditioning. He is the founder, board of directors member, and past vice chair of the first district cooling company in Egypt, GasCool. He is a member of the Refrigeration and AirConditioning Technical Options Committee of the United Nations Environment

Programme. Dr. Olama is the head of the committee writing the first District Cooling code for Egypt and a member of the committee writing the Egyptian Code of Air Conditioners, Refrigeration and Automatic Control and the Arab Refrigeration and Air-Conditioning Code. He is a past president of the Board of Directors of ASHRAE Cairo Chapter 2002-2003 and general Chair, ASHRAE, of the Second Regional Conference of Refrigeration (ARC) Region-At-Large in Cairo, September 2003. He is a member of the international reviewers' panel of the low-GWP refrigerants testing program of PRAHA and a technical advisor of EGYPRA. Dr. Olama is an independent consultant.

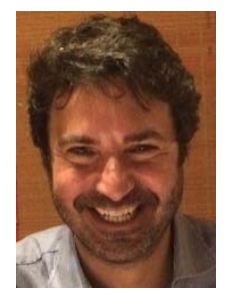

\section{Dr. Alessandro Giuliano Peru (Italy)}

Dr. Peru was a researcher at the University Consortium CUEIM, where he co-authored several research papers and technical reports for the protection of the environment. He has worked for more than 15 years in the ozone protection field. He was in charge of national plans for the phaseout of ozone-depleting and high-GWP substances from 2000 to 2010. Starting in 2006, he was in charge, as financial expert, of the mobilization of financial resources and budget of the multi-environmental agreements and member of the executive committee of 
the Multilateral Fund of the Montreal Protocol for the years 2006-2007 and 2014-2015. Dr. Peru has chaired and coordinated many technical working groups at both the European and international level.

In addition, he was in charge of several bilateral and multilateral cooperation programs. In 2014, he was President of the European Union for the Montreal Protocol during the Italian Presidency of the Council of the European Union. He is the author of several articles and publications on environmental issues and former Professor of Economics and Management at the Faculty of Economics at the University "La Sapienza.”

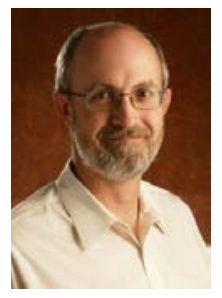

\section{Dr. Patrick Phelan (co-chair; USA)}

Patrick Phelan received his BS degree from Tulane University (New Orleans, Louisiana, USA), his MS degree from the Massachusetts Institute of Technology (USA), and his PhD from the University of California, Berkeley (USA), all in mechanical engineering. Following a 2 year postdoctoral fellowship at the Tokyo Institute of Technology (Japan), he started his academic career as an Assistant Professor at the University of Hawaii in 1992. In 1996 he moved to Arizona State University (USA), where he is a Professor of Mechanical and Aerospace Engineering and a Senior Sustainability Scientist. While on leave from Arizona State University, he served as the Director of the National Science Foundation Thermal Transport Processes Program from 2006 to 2008. Dr. Phelan is currently on leave from Arizona State University and is now the Program Manager for Emerging Technologies in the Building Technologies Office, Energy Efficiency and Renewable Energy, US Department of Energy. 

APPENDIX B. OTHER HIGH-AMBIENT-TEMPERATURE TESTING PROGRAMS 



\section{APPENDIX B. OTHER HIGH-AMBIENT-TEMPERATURE TESTING PROGRAMS}

\section{Comparison with other high-ambient-temperature testing programs:}

Table B.1 compares the ORNL Evaluation Program with three other high-ambient-temperature testing programs. Low-GWP AREP includes testing of a wide range of equipment; Table B.1 covers only a subset that is directly applicable to this report.

Table B.1. Comparison of high-ambient-temperature testing programs

\begin{tabular}{|c|c|c|c|c|c|c|c|}
\hline & \multicolumn{2}{|c|}{ ORNL Evaluation Program } & \multicolumn{5}{|c|}{$\begin{array}{c}\text { EGYPRA } \\
\text { (UNEP, UNIDO, Egypt) }\end{array}$} \\
\hline Type of test & \multicolumn{2}{|c|}{$\begin{array}{l}\text { Soft-optimized tests, comparing with base } \\
\text { units: R-22 and R-410A }\end{array}$} & \multicolumn{5}{|c|}{$\begin{array}{l}\text { Individual test prototypes, comparing with base } \\
\text { units: R-22 and R-410A }\end{array}$} \\
\hline $\begin{array}{l}\text { Number of } \\
\text { prototypes }\end{array}$ & \multicolumn{2}{|c|}{$\begin{array}{l}\text { Two commercially available units, soft- } \\
\text { optimized to compare with base } \\
\text { refrigerants: R-22, R-410A }\end{array}$} & \multicolumn{5}{|c|}{$\begin{array}{l}36 \text { prototypes, each specific to one capacity and one } \\
\text { refrigerant, compared with base units: R-22, } \\
\text { R-410A }\end{array}$} \\
\hline \multirow[b]{2}{*}{ Categories } & \multicolumn{2}{|c|}{$60 \mathrm{~Hz}$} & \multicolumn{5}{|c|}{$50 \mathrm{~Hz}$} \\
\hline & $\begin{array}{l}\text { Split unit } \\
18 \mathrm{MBH} \\
\text { (designed for } \\
\text { R-22) }\end{array}$ & $\begin{array}{c}\text { Split unit } \\
18 \mathrm{MBH} \\
\text { (designed for R-410A) }\end{array}$ & $\begin{array}{l}\text { Split } \\
12 \\
\text { MBH }\end{array}$ & $\begin{array}{l}\text { Split } \\
18 \\
\mathrm{MBH}\end{array}$ & $\begin{array}{l}\text { Split } \\
24 \\
\mathrm{MBH}\end{array}$ & $\begin{array}{l}\text { Central } \\
120 \\
\mathrm{MBH}\end{array}$ & $\begin{array}{l}\text { Central micro } \\
\text { channel } \\
120 \mathrm{MBH}\end{array}$ \\
\hline $\begin{array}{l}\text { Testing } \\
\text { conditions }\end{array}$ & \multicolumn{2}{|c|}{$\begin{array}{l}\text { ANSI/AHRI Standard } 210 / 240 \text { and ISO T3 } \\
\text { condition, } 52^{\circ} \mathrm{C} \text {, and } 55^{\circ} \mathrm{C}\end{array}$} & \multicolumn{5}{|c|}{$\begin{array}{l}\text { EOS } 4814 \text { and } 3795 \text { (ISO 5151), T1 conditions plus } \\
\text { one point in T3 conditions }\end{array}$} \\
\hline $\begin{array}{l}\text { Prototypes } \\
\text { supplied \& } \\
\text { tests } \\
\text { performed }\end{array}$ & \multicolumn{2}{|c|}{$\begin{array}{l}\text { Oak Ridge National Laboratory, one } \\
\text { supplier-soft-optimization in situ }\end{array}$} & \multicolumn{5}{|c|}{$\begin{array}{l}\text { Prototypes built at eight OEMs, test at NREA (local } \\
\text { test laboratory in Egypt) }\end{array}$} \\
\hline $\begin{array}{l}\text { Refrigerants } \\
\text { tested }\end{array}$ & \multicolumn{2}{|c|}{$\begin{array}{l}\text { R-32, R-290, } \\
\text { HFC/HFO blends ( } 4 \text { types) vs. R-22 } \\
\text { HFC/HFO blends ( } 4 \text { types) vs. R-410A }\end{array}$} & \multicolumn{5}{|c|}{$\begin{array}{l}\text { R-32, R-290, } \\
\text { HFC/HFO blends ( } 3 \text { types) vs. R-22 } \\
\text { HFC/HFO blends ( } 3 \text { types) vs. R-410A }\end{array}$} \\
\hline $\begin{array}{l}\text { Expected } \\
\text { delivery } \\
\text { dates }\end{array}$ & \multicolumn{2}{|c|}{$\begin{array}{l}\text { Preliminary report, July } 2015 \\
\text { Final report, October } 2015\end{array}$} & \multicolumn{5}{|c|}{ Early 2016} \\
\hline Constraints & \multicolumn{2}{|c|}{$\begin{array}{l}\text { To change some components of the two } \\
\text { prototypes to accommodate the different } \\
\text { refrigerant characteristics, within a soft- } \\
\text { optimization process }\end{array}$} & \multicolumn{5}{|c|}{$\begin{array}{l}\text { To build new prototypes with dedicated } \\
\text { compressors for the selected refrigerants with the } \\
\text { condition to meet the same design capacities of the } \\
\text { selected models in comparison with the R- } 22 \text { or } \\
\text { R-410A designs }\end{array}$} \\
\hline $\begin{array}{l}\text { Other } \\
\text { components }\end{array}$ & \multicolumn{2}{|r|}{ N/A } & \multicolumn{5}{|c|}{ N/A } \\
\hline
\end{tabular}


Table B.1. (continued)

\begin{tabular}{|c|c|c|c|c|c|c|c|}
\hline & \multicolumn{3}{|c|}{$\begin{array}{c}\text { PRAHA } \\
\text { (UNEP, UNIDO, high-ambient- } \\
\text { temperature countries) }\end{array}$} & \multicolumn{4}{|c|}{ Low-GWP AREP (AHRI) ${ }^{a}$} \\
\hline Type of test & \multicolumn{3}{|c|}{$\begin{array}{l}\text { Individual test prototypes, comparing } \\
\text { with base units: R-22 and R-410A }\end{array}$} & \multicolumn{4}{|c|}{$\begin{array}{l}\text { Soft-optimization and drop-in tests. Baseline units } \\
\text { vary by application. }\end{array}$} \\
\hline $\begin{array}{l}\text { Number of } \\
\text { prototypes }\end{array}$ & \multicolumn{3}{|c|}{$\begin{array}{l}22 \text { prototypes, each specific to one capacity } \\
\text { and one refrigerant, compared with base units: } \\
\text { R-22, R-410A }\end{array}$} & \multirow{2}{*}{\multicolumn{4}{|c|}{$\begin{array}{l}\text { Data for } 6 \text { prototypes has been published so far } \\
\text { (including data for a VRF unit at moderate ambient } \\
\text { conditions), but } 18 \text { reports with high-ambient- } \\
\text { temperature testing are expected in total. } \\
\qquad 60 \mathrm{~Hz}\end{array}$}} \\
\hline & \multicolumn{2}{|c|}{$60 \mathrm{~Hz}$} & $50 \mathrm{~Hz}$ & & & & \\
\hline Categories & $\begin{array}{l}\text { Window } \\
18 \mathrm{MBH}\end{array}$ & $\begin{array}{l}\text { Decorative } \\
\text { split } \\
24 \mathrm{MBH}\end{array}$ & $\begin{array}{cc}\text { Ducted } & \text { Packaged } \\
36 \mathrm{MBH} & 90 \mathrm{MBH}\end{array}$ & $\begin{array}{l}\text { Split central } \\
\text { AC } \\
36 \mathrm{MBH}\end{array}$ & $\begin{array}{l}\text { Split central } \\
\text { HP } \\
36 \mathrm{MBH}\end{array}$ & $\begin{array}{l}\text { Split central } \\
\text { HP } \\
42 \mathrm{MBH}\end{array}$ & $\begin{array}{l}\text { Variable } \\
\text { refrigerant } \\
\text { flow } \\
\text { (VRF) HP } \\
96 \mathrm{MBH}\end{array}$ \\
\hline $\begin{array}{l}\text { Testing } \\
\text { conditions }\end{array}$ & \multicolumn{3}{|c|}{$\begin{array}{l}\text { ISO } 5151 \text { at } \mathrm{T} 1, \mathrm{~T} 3 \text { and } \mathrm{T} 3+\left(50^{\circ} \mathrm{C}\right) \text { and a } \\
\text { continuity test for } 2 \mathrm{~h} \text { at } 52^{\circ} \mathrm{C}\end{array}$} & $\begin{array}{l}\text { ANSI/AHRI } \\
\text { Standard } \\
210 / 240 \text {, } \\
\text { additional } \\
\text { tests at } \\
46.1^{\circ} \mathrm{C} \text { and } \\
51.7^{\circ} \mathrm{C}\end{array}$ & $\begin{array}{l}\text { ASHRAE } \\
\text { Standard } 116\end{array}$ & $\begin{array}{l}\text { ANSI/AHRI } \\
\text { Standard } \\
210 / 240, \\
\text { additional } \\
\text { test at } 46.1^{\circ} \mathrm{C}\end{array}$ & $\begin{array}{l}\text { AHRI } \\
1230 \text { and } \\
\text { ASHRAE } \\
37\end{array}$ \\
\hline $\begin{array}{l}\text { Prototypes } \\
\text { supplied \& } \\
\text { tests } \\
\text { performed }\end{array}$ & \multicolumn{3}{|c|}{ Prototypes built at 7 OEMs, test at Intertek } & \multicolumn{4}{|c|}{$\begin{array}{l}\text { Units were manufactured or obtained by each party } \\
\text { and tested at each party's facilities }\end{array}$} \\
\hline $\begin{array}{l}\text { Refrigerants } \\
\text { tested }\end{array}$ & \multicolumn{3}{|c|}{$\begin{array}{l}\text { R-32, R-290 } \\
\text { HFC/HFO blends ( } 2 \text { types) vs. R-22 } \\
\text { HFC/HFO blends ( } 2 \text { types) vs. } \\
\text { R-410A }\end{array}$} & \multicolumn{4}{|c|}{$\begin{array}{l}\text { For nonautomotive air-conditioning applications, the } \\
\text { final list of refrigerants is expected to include } \\
\text { R-1234yf, R-32, D2Y60, L-41a, D-52Y, ARM-71a, } \\
\text { DR-5A, HPR-2A, L-41-1 and L-41-2 }\end{array}$} \\
\hline $\begin{array}{l}\text { Expected } \\
\text { delivery dates }\end{array}$ & \multicolumn{3}{|c|}{ 4th quarter of 2015} & \multicolumn{4}{|c|}{$\begin{array}{l}\text { Phase I results have already been published; Phase II } \\
\text { results are currently being published on a rolling basis }\end{array}$} \\
\hline Constraints & \multicolumn{3}{|c|}{$\begin{array}{l}\text { To build new prototypes with dedicated } \\
\text { compressors for the selected refrigerants with } \\
\text { the condition to meet the same design } \\
\text { capacities of the selected models in } \\
\text { comparison with the R-22 or R-410A designs }\end{array}$} & \multicolumn{4}{|c|}{$\begin{array}{l}\text { To conduct drop-in system tests and soft-optimized } \\
\text { tests with any modifications clearly indicated in the } \\
\text { test reports }\end{array}$} \\
\hline $\begin{array}{l}\text { Other } \\
\text { components }\end{array}$ & \multicolumn{3}{|c|}{$\begin{array}{l}\text { The project includes other nontesting elements } \\
\text { to assess relevant issues of energy efficiency } \\
\text { standards, technology transfer, and economics, } \\
\text { in addition to special reporting on the potential } \\
\text { of district cooling to reduce the use of high- } \\
\text { GWP alternatives. }\end{array}$} & \multicolumn{4}{|c|}{$\begin{array}{l}\text { Compressor calorimeter tests and heat transfer tests } \\
\text { are also performed }\end{array}$} \\
\hline
\end{tabular}

\footnotetext{
${ }^{a}$ Only includes test results that are directly related to this report.
} 


\section{PRAHA test plan:}

The test plan for PRAHA is shown in Table B.2.

Table B.2. PRAHA test plan summary

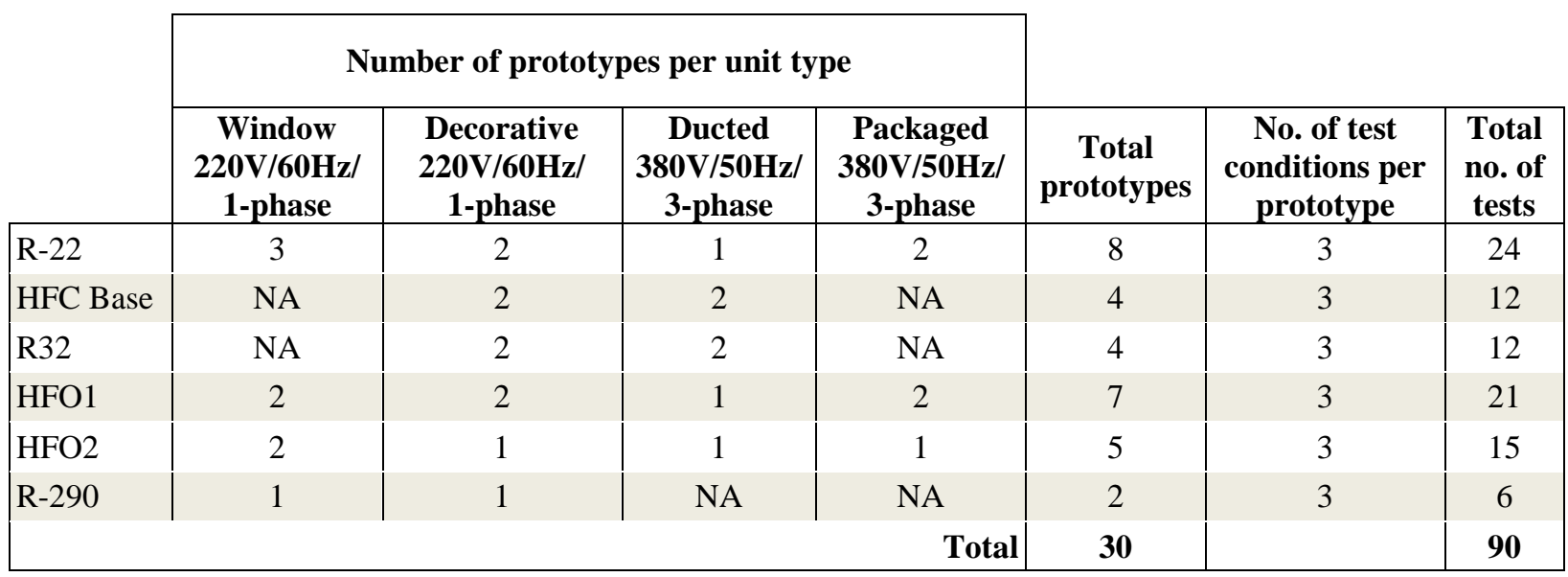

Source: Elassaad, B. (2014). “Alternative Refrigerants for High-ambient Countries; Risk Assessment of Future Refrigerants in Production, Installation, and Service,” presentation at the 4th Symposium Low GWP Alternatives for High Ambient, October 28, 2014; Dubai, UAE. Available at http://4thhighambient.com/presentations/4th\%20sypm\%20Day\%201/Session-

III\%20P03\%20UNEP-UNIDO\%20PRAHA.pdf.

\section{Low-GWP AREP test plan:}

Phase I of Low-GWP AREP ended in 2013 and led to 40 reports pertaining to a total of 38 refrigerants. A few conclusions can be drawn from the results of Phase I. [17]

- Several alternative refrigerants had performed similarly to the baseline refrigerants they replaced.

- It is unlikely that a single refrigerant will replace R-22, R-134a, R-404A, and R-410A. Most likely, the alternative replacement used will depend on the application.

- AREP focused on drop-in replacements and soft-optimized equipment. It is possible that further improvements could be attained by further soft-optimization or by full optimization of the equipment for the alternative replacement.

- There were inconsistencies in the test results, which may have been caused by the comparison across product types, sizes, and manufacturers and from using different testing facilities.

Phase I was not initially planned to include high-ambient-temperature testing, but some testing parties chose to include high-ambient-temperature results in their reports. Phase II began in 2014 and includes new refrigerants and an increased focus on high-ambient-temperature testing. Twenty-five refrigerants were proposed for Phase II, of which 15 will be tested. Eight of the test plans include high-ambienttemperature conditions; and in total, nine alternative refrigerants are being tested at high ambient temperatures. The test matrix is listed in Table B.3 and Table B.4.

For individual test reports and further details, please refer to the AREP website.

\footnotetext{
${ }^{*}$ For test reports and further details, refer to http://www.ahrinet.org/site/514/Resources/Research/AHRI-Low-GWP-AlternativeRefrigerants-Evaluation
} 
Table B.3. Low-GWP AREP Phase I high-ambient-temperature test matrix

\begin{tabular}{|c|c|c|c|c|c|c|c|c|c|c|c|c|c|c|}
\hline Product & $\begin{array}{c}\text { Test } \\
\text { companies }\end{array}$ & $\begin{array}{l}\text { High-ambient } \\
\text { conditions }\end{array}$ & $\begin{array}{c}\text { Low- } \\
\text { GWP } \\
\text { AREP } \\
\text { report no. }\end{array}$ & $\begin{array}{c}\text { Baseline } \\
\text { refrigerant }\end{array}$ & 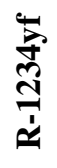 & జี & 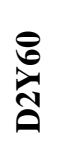 & 疍 & 古 & $\begin{array}{l}\text { oे } \\
\text { y } \\
\text { z }\end{array}$ & 照 & $\frac{\tilde{m}}{\tilde{7}}$ & 光 & 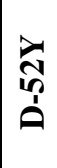 \\
\hline $\begin{array}{l}3.5 \text { TR split } \\
\text { system HP }\end{array}$ & Lennox & $46.1^{\circ} \mathrm{C}\left(115^{\circ} \mathrm{F}\right)$ & No. 10 & R-410A & $x$ & & & & & & & & & \\
\hline $\begin{array}{l}3.5 \text { TR split } \\
\text { system HP }\end{array}$ & Lennox & $46.1^{\circ} \mathrm{C}\left(115^{\circ} \mathrm{F}\right)$ & No. 4 & $\mathrm{R}-410 \mathrm{~A}$ & & $x$ & & & & & & & & \\
\hline $\begin{array}{l}3 \text { TR split } \\
\text { system HP }\end{array}$ & $\begin{array}{l}\text { Univ of } \\
\text { Maryland }\end{array}$ & $46.1^{\circ} \mathrm{C}\left(115^{\circ} \mathrm{F}\right)$ & No. 20 & $\mathrm{R}-410 \mathrm{~A}$ & & $x$ & $x$ & $x$ & & & & & & \\
\hline $\begin{array}{l}3 \text { TR split } \\
\text { system HP }\end{array}$ & $\begin{array}{l}\text { Univ of } \\
\text { Maryland }\end{array}$ & $46.1^{\circ} \mathrm{C}\left(115^{\circ} \mathrm{F}\right)$ & No. 23 & $\mathrm{R}-410 \mathrm{~A}$ & & & & $x$ & & & & & & \\
\hline $\begin{array}{l}3 \text { TR split } \\
\text { system HP }\end{array}$ & $\begin{array}{l}\text { Univ of } \\
\text { Maryland }\end{array}$ & $46.1^{\circ} \mathrm{C}\left(115^{\circ} \mathrm{F}\right)$ & No. 32 & $\mathrm{R}-410 \mathrm{~A}$ & & & $x$ & & & & & & & \\
\hline $\begin{array}{c}\text { Ice machine } \\
\text { (self-contained) }\end{array}$ & Manitowoc & $43.3^{\circ} \mathrm{C}\left(110^{\circ} \mathrm{F}\right)$ & No. 2 & $\mathrm{R}-404 \mathrm{~A}$ & & & & & $x$ & $x$ & & & & \\
\hline $\begin{array}{l}\text { Ice machine } \\
\text { (split system) }\end{array}$ & Manitowoc & $48.9^{\circ} \mathrm{C}\left(120^{\circ} \mathrm{F}\right)$ & No. 2 & $\mathrm{R}-404 \mathrm{~A}$ & & & & & $x$ & $x$ & & & & \\
\hline Bus AC system & ThermoKing & $48.9^{\circ} \mathrm{C}\left(120^{\circ} \mathrm{F}\right)$ & No. 12 & $\mathrm{R}-134 \mathrm{~A}$ & & & & & & & $x$ & $x$ & & \\
\hline Bus AC system & ThermoKing & $48.9^{\circ} \mathrm{C}\left(120^{\circ} \mathrm{F}\right)$ & No. 13 & $\mathrm{R}-407 \mathrm{C}$ & & & & & & & & & $x$ & $x$ \\
\hline $\begin{array}{l}\text { VRF multi-split } \\
\text { HP }\end{array}$ & Daikin & $\begin{array}{l}18.3^{\circ} \mathrm{C}\left(65^{\circ} \mathrm{F}\right), \\
20.0^{\circ} \mathrm{C}\left(68^{\circ} \mathrm{F}\right), \\
26.7^{\circ} \mathrm{C}\left(80^{\circ} \mathrm{F}\right), \\
35.0^{\circ} \mathrm{C}\left(95^{\circ} \mathrm{F}\right)\end{array}$ & No. 15 & $\mathrm{R}-410 \mathrm{~A}$ & & & & & & & & & & $x$ \\
\hline
\end{tabular}

Table B.4. Low-GWP AREP Phase II high-ambient-temperature test matrix

\begin{tabular}{|c|c|c|c|c|c|c|c|c|c|c|c|c|c|}
\hline Product & $\begin{array}{c}\text { Test } \\
\text { companies }\end{array}$ & $\begin{array}{l}\text { High-ambient } \\
\text { conditions }\end{array}$ & $\begin{array}{c}\text { Low-GWP } \\
\text { AREP } \\
\text { report no. }\end{array}$ & $\begin{array}{l}\text { Baseline } \\
\text { refrigerant }\end{array}$ & 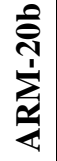 & 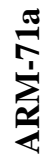 & 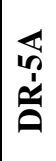 & 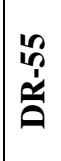 & 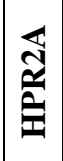 & 章 & 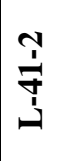 & 官 & $\tilde{\tilde{z}}$ \\
\hline $10 \mathrm{~kW}$ water chiller & Armines & $46.1^{\circ} \mathrm{C}\left(115^{\circ} \mathrm{F}\right)$ & No. 46 & $\mathrm{R}-410 \mathrm{~A}$ & & $x$ & $x$ & & & $x$ & $x$ & & \\
\hline $\begin{array}{l}\text { 11.3 EER } 10 \mathrm{TR} \\
\text { rooftop unit }\end{array}$ & Carrier & $51.7^{\circ} \mathrm{C}\left(125^{\circ} \mathrm{F}\right)$ & (In testing) & $\mathrm{R}-410 \mathrm{~A}$ & & & $x$ & & & $x$ & $x$ & & $x$ \\
\hline 14 SEER 3 TR HP & Carrier & $51.7^{\circ} \mathrm{C}\left(125^{\circ} \mathrm{F}\right)$ & No. 52 & $\mathrm{R}-410 \mathrm{~A}$ & & $x$ & $x$ & & $x$ & $x$ & $x$ & & \\
\hline 13 SEER 3 TR HP & Danfoss & $\begin{array}{l}46.1^{\circ} \mathrm{C}\left(115^{\circ} \mathrm{F}\right), \\
51.7^{\circ} \mathrm{C}\left(125^{\circ} \mathrm{F}\right)\end{array}$ & No. 54 & $\mathrm{R}-410 \mathrm{~A}$ & & & $x$ & & & & $x$ & & $x$ \\
\hline $\begin{array}{l}14 \text { SEER } 3 \text { TR } \\
\text { split AC }\end{array}$ & Goodman & $\begin{array}{l}46.1^{\circ} \mathrm{C}\left(115^{\circ} \mathrm{F}\right) \\
51.7^{\circ} \mathrm{C}\left(125^{\circ} \mathrm{F}\right)\end{array}$ & No. 42 & $\mathrm{R}-410 \mathrm{~A}$ & & & & & & & & & $x$ \\
\hline $\begin{array}{l}\text { Commercial } \\
\text { package unit }\end{array}$ & Lennox & $\begin{array}{l}46.1^{\circ} \mathrm{C}\left(115^{\circ} \mathrm{F}\right) \\
51.7^{\circ} \mathrm{C}\left(125^{\circ} \mathrm{F}\right)\end{array}$ & $\begin{array}{l}\text { No. } 47 \text { and } \\
\text { No. } 53\end{array}$ & R-410A & & $x$ & $x$ & $x$ & $x$ & & $x$ & & $x$ \\
\hline Split ice machine & Manitowoc & $48.9^{\circ} \mathrm{C}\left(120^{\circ} \mathrm{F}\right)$ & No. 45 & $\mathrm{R}-404 \mathrm{~A}$ & $x$ & & & & & & & $x$ & \\
\hline $\begin{array}{l}4 \text { TR packaged } \\
\text { rooftop unit }\end{array}$ & Trane & $51.7^{\circ} \mathrm{C}\left(125^{\circ} \mathrm{F}\right)$ & No. 56 & $\mathrm{R}-410 \mathrm{~A}$ & & & $x$ & $x$ & & & & & $x$ \\
\hline $\begin{array}{c}\text { Rooftop packaged } \\
\text { unit }\end{array}$ & Zamilac & $51.7^{\circ} \mathrm{C}\left(125^{\circ} \mathrm{F}\right)$ & No. 55 & $\mathrm{R}-410 \mathrm{~A}$ & & & & & & & & & $x$ \\
\hline
\end{tabular}




\section{APPENDIX C. EXPERIMENTAL TEST SETUP}





\section{APPENDIX C. EXPERIMENTAL TEST SETUP}

Figure C.1 and Figure C.2 provide an overview of the ORNL experimental test setup, with the measurement locations indicated. The as-installed system is shown in Figure C.3 and Figure C.4 for the R-22 unit. Finally, the fully instrumented outdoor unit is shown as installed in Figure C.5, and the details of the capillary tube installation are shown in Figure C.6, all for the R-22 unit.

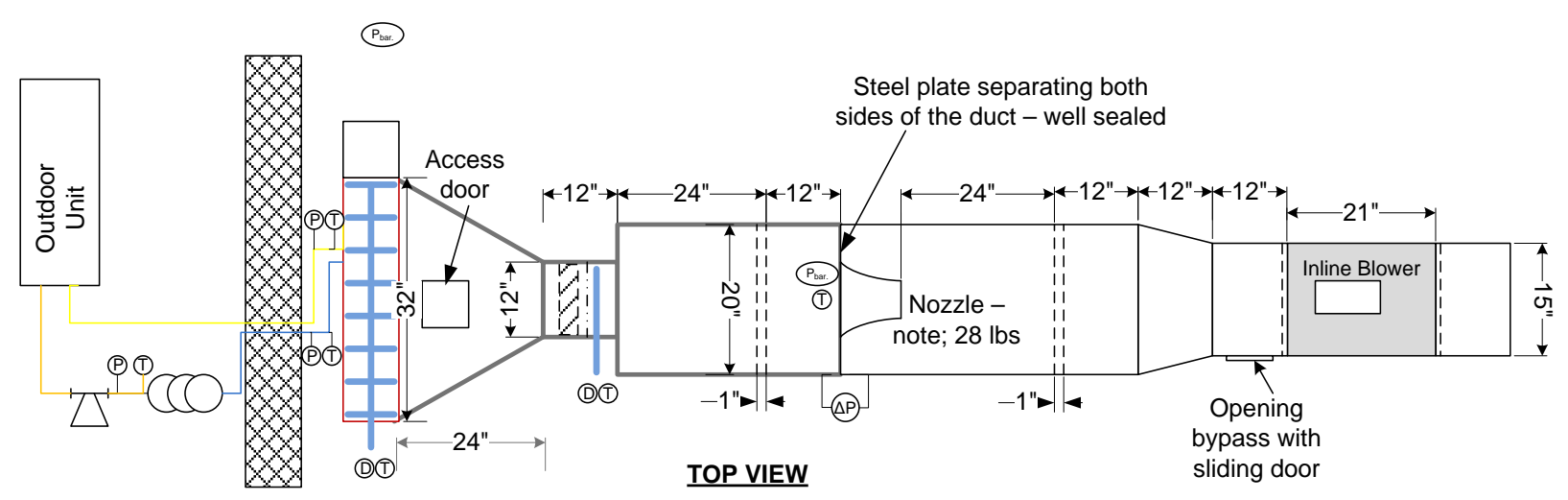

Figure C.1. Top view of the experimental setup showing both the indoor side and the outdoor side, along with instrumentation locations and design of the air enthalpy tunnel. For line legend, please refer to Figure C.2.

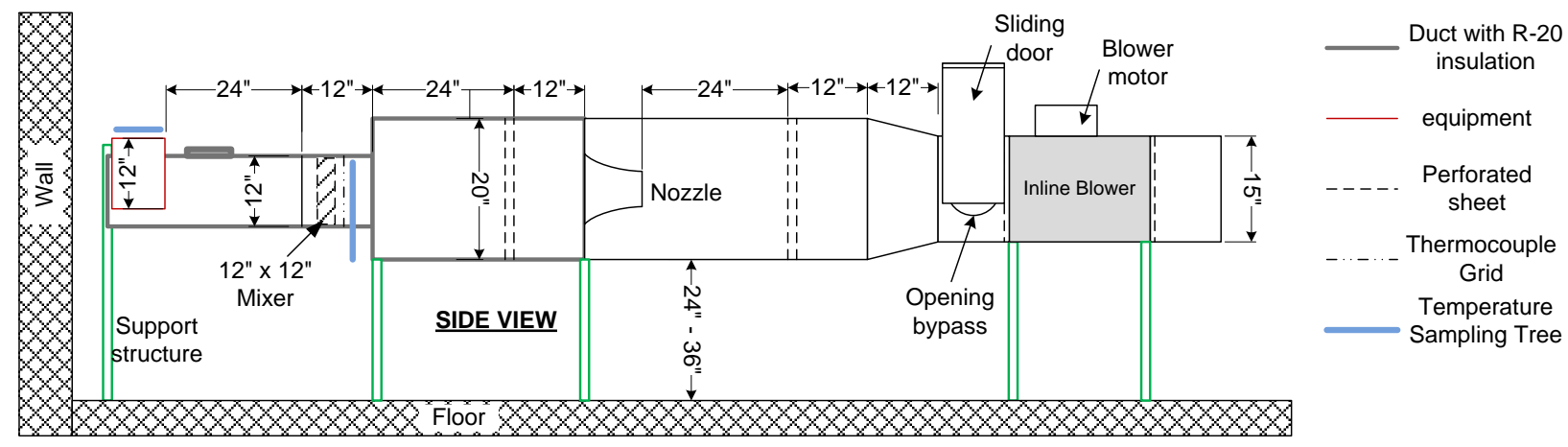

Figure C.2. Side view of the air enthalpy tunnel showing additional details and legend for the lines. 


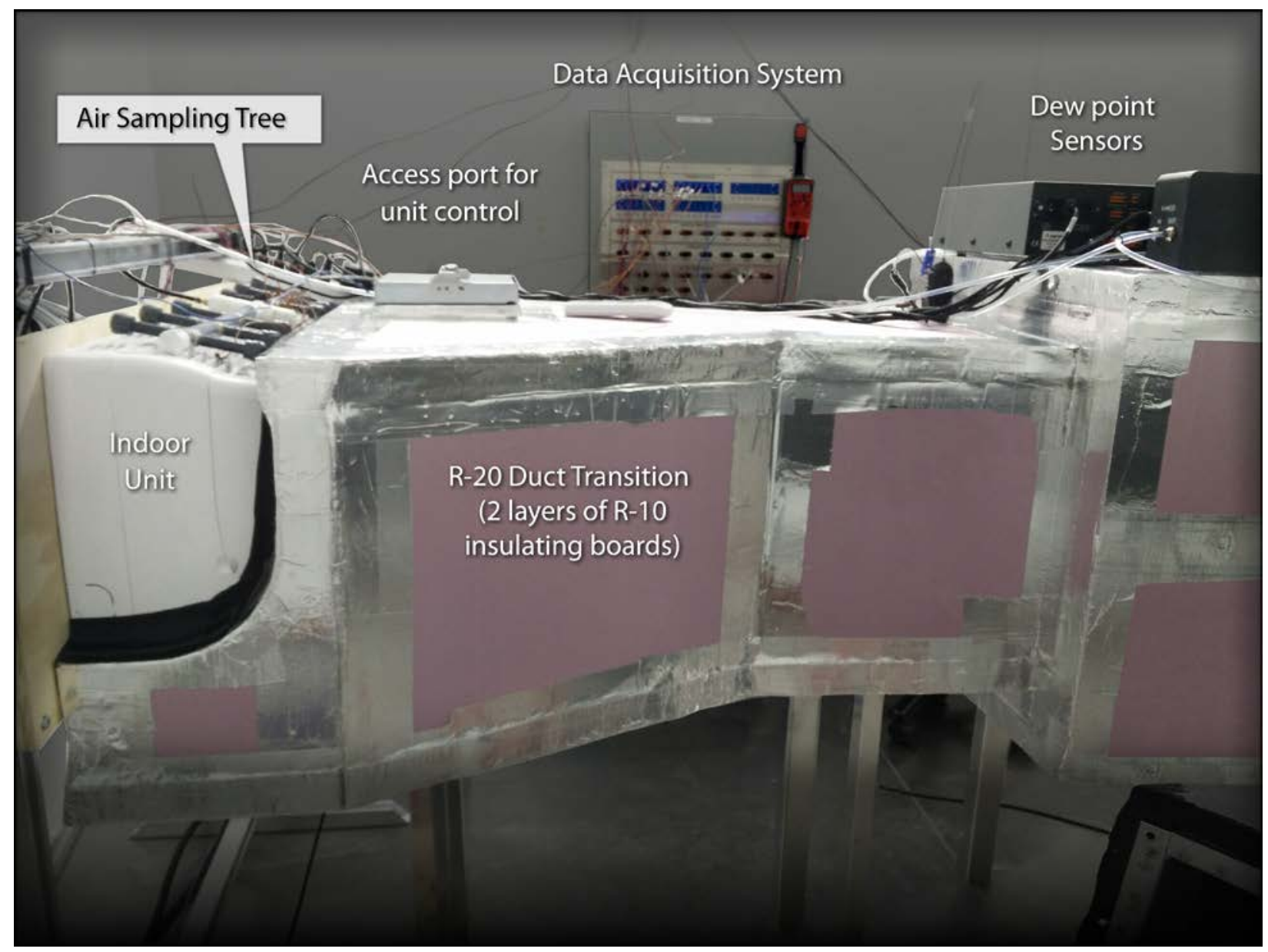

Figure C.3. As-installed R-22 indoor unit, showing the sampling tree on the return air and the two-layer insulation ( $R-20$ effective insulation). 


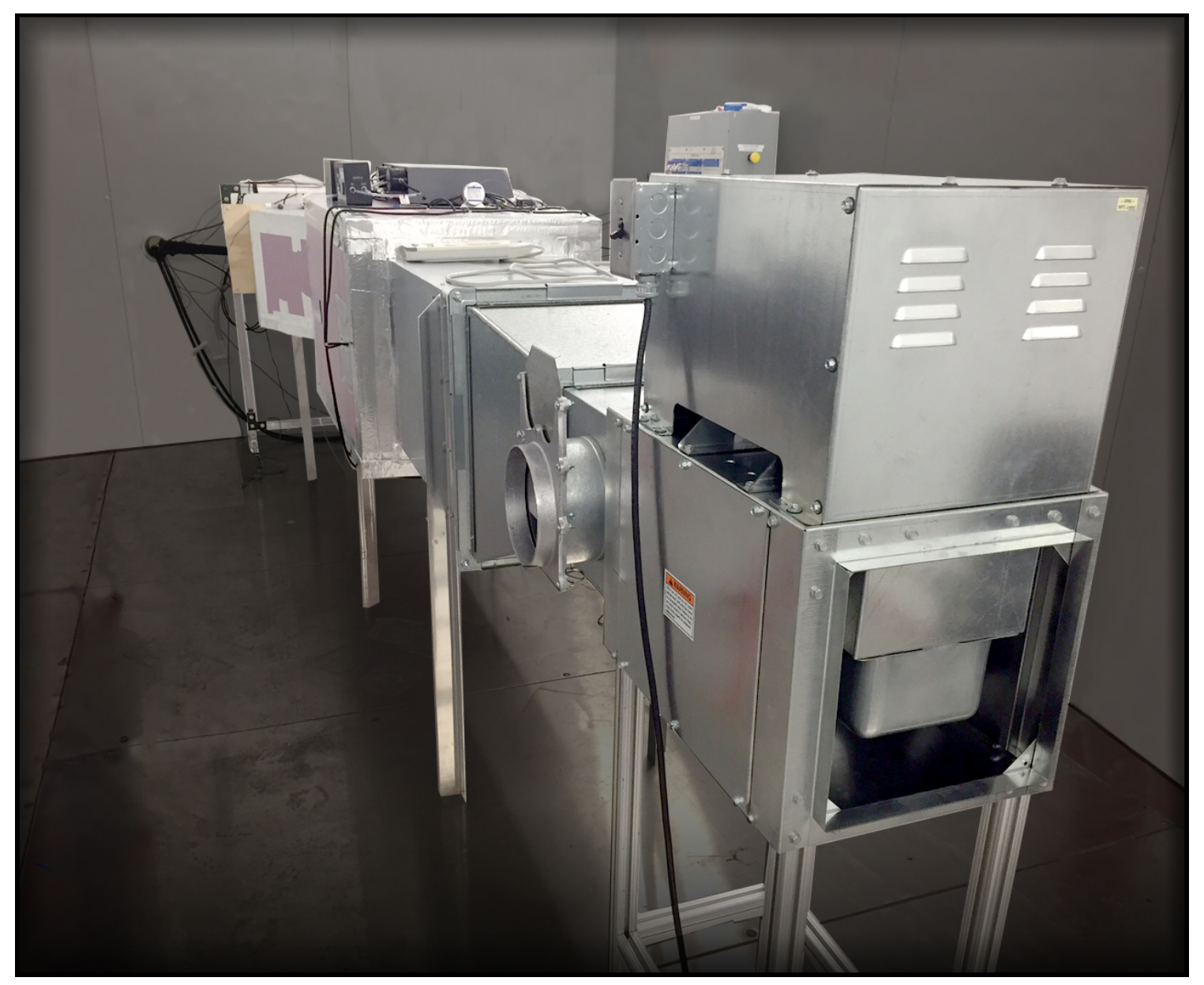

Figure C.4. R-22 indoor air enthalpy tunnel fully instrumented and connected to the data acquisition system. 


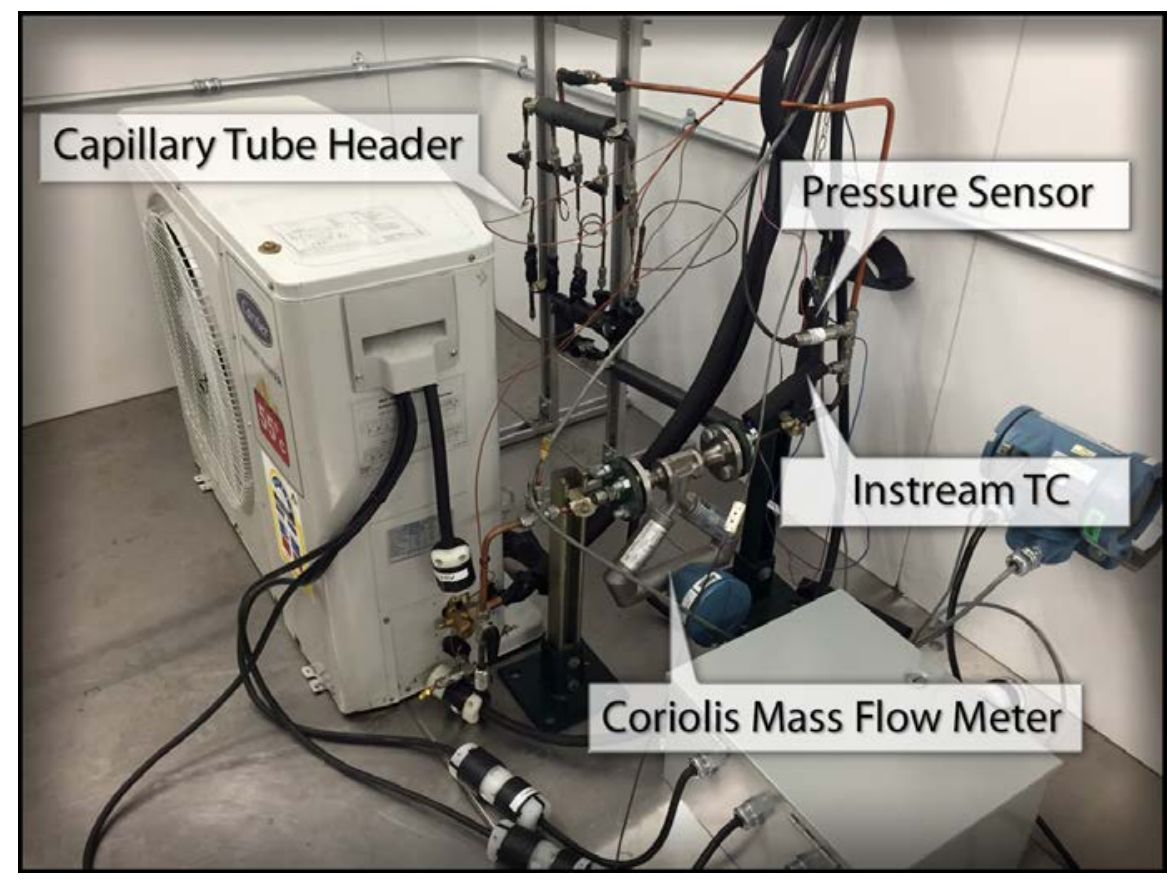

Figure C.5. R-22 outdoor unit showing Coriolis mass flow meter, pressure and temperature sensors, and capillary tube. 


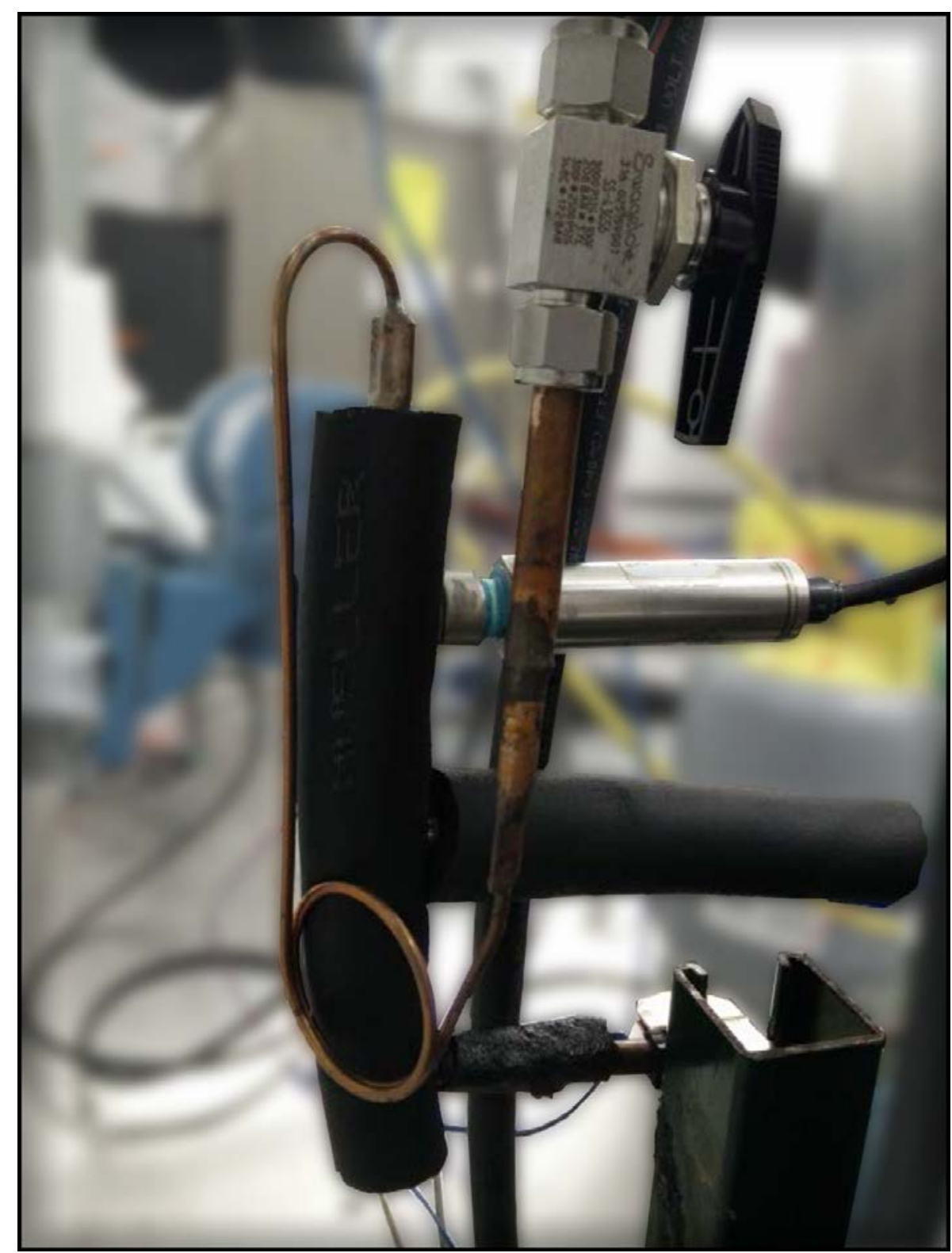

Figure C.6. R-22 original capillary tube downstream of the pressure and temperature sensors.

Table C.1 provides a summary of the instrumentation used for testing of the R-22 unit, and Table C.2 provides a summary of the instrumentation used for testing of the R-410A unit. 
Table C.1. R-22 unit experimental setup instrumentation

\begin{tabular}{|c|c|c|c|}
\hline Data & Instrument & Range and accuracy & Comments \\
\hline $\begin{array}{l}\text { Indoor unit air inlet } \\
\text { temperature }\end{array}$ & T-type thermocouple & $\begin{array}{l}1.7 \text { to } 79.4^{\circ} \mathrm{C}, \pm 0.28^{\circ} \mathrm{C} \\
\text { (35 to } 175^{\circ} \mathrm{F}, \pm 0.5^{\circ} \mathrm{F} \text { ) }\end{array}$ & \multirow{4}{*}{$\begin{array}{l}\text { Using aspirated } \\
\text { sampling } \\
\text { temperature tree }\end{array}$} \\
\hline $\begin{array}{l}\text { Indoor unit air inlet } \\
\text { dew point }\end{array}$ & $\begin{array}{l}\text { DewMaster EdgeTech Chilled } \\
\text { mirror hygrometer }\end{array}$ & $\begin{array}{l}-40 \text { to } 95^{\circ} \mathrm{C}, \pm 0.2^{\circ} \mathrm{C} \\
\left(-40 \text { to } 203^{\circ} \mathrm{F}, \pm 0.36^{\circ} \mathrm{F}\right)\end{array}$ & \\
\hline $\begin{array}{l}\text { Indoor unit air outlet } \\
\text { temperature }\end{array}$ & T-type thermocouple & $\begin{array}{l}1.7 \text { to } 79.4^{\circ} \mathrm{C}, \pm 0.28^{\circ} \mathrm{C} \\
\text { (35 to } 175^{\circ} \mathrm{F}, \pm 0.5^{\circ} \mathrm{F} \text { ) }\end{array}$ & \\
\hline $\begin{array}{l}\text { Indoor unit air outlet } \\
\text { dew point }\end{array}$ & $\begin{array}{l}\text { DewMaster EdgeTech Chilled } \\
\text { mirror hygrometer }\end{array}$ & $\begin{array}{l}-40 \text { to } 95^{\circ} \mathrm{C}, \pm 0.2^{\circ} \mathrm{C} \\
\left(-40 \text { to } 203^{\circ} \mathrm{F}, \pm 0.36^{\circ} \mathrm{F}\right)\end{array}$ & \\
\hline Condensate rate & Sartorius Midrics electronic scale & $\begin{array}{l}0 \text { to } 30 \mathrm{~kg}, \\
2 \text { g readability }\end{array}$ & \\
\hline Airflow rate & 127 mm (5 in.) nozzle & & \multirow{4}{*}{$\begin{array}{l}\text { Air mass flow rate } \\
\text { measurement }\end{array}$} \\
\hline $\begin{array}{l}\text { Nozzle upstream } \\
\text { barometric pressure }\end{array}$ & $\begin{array}{l}\text { Setra model } 278 \text { barometric } \\
\text { pressure sensor }\end{array}$ & $\begin{array}{l}800 \text { to } 1100 \mathrm{hPa} / \mathrm{mb} \text {, } \\
\pm 0.6 \mathrm{hPa} / \mathrm{mb}\end{array}$ & \\
\hline $\begin{array}{l}\text { Temperature } \\
\text { upstream of the } \\
\text { nozzle }\end{array}$ & T-type thermocouple & $\begin{array}{l}1.7 \text { to } 79.4^{\circ} \mathrm{C}, \pm 0.28^{\circ} \mathrm{C} \\
\text { ( } 35 \text { to } 175^{\circ} \mathrm{F}, \pm 0.5^{\circ} \mathrm{F} \text { ) }\end{array}$ & \\
\hline $\begin{array}{l}\text { Pressure drop across } \\
\text { the nozzle }\end{array}$ & $\begin{array}{l}\text { Setra Model } 239 \text { differential } \\
\text { pressure sensor }\end{array}$ & $\begin{array}{l}0 \text { to } 5 \text { in. } \mathrm{H}_{2} \mathrm{O} \\
\pm 0.073 \% \mathrm{FS}\end{array}$ & \\
\hline Liquid line pressure & $\begin{array}{l}\text { Omega Pressure Transducer } \\
\text { PX409 absolute pressure sensor }\end{array}$ & $\begin{array}{l}0-750 \mathrm{psiA} \\
\pm 0.08 \% \mathrm{BSL}\end{array}$ & \multirow{2}{*}{$\begin{array}{l}\text { Used to evaluate } \\
\text { evaporator inlet } \\
\text { enthalpy }\end{array}$} \\
\hline $\begin{array}{l}\text { Liquid line } \\
\text { temperature }\end{array}$ & In-stream T-type thermocouple & $\begin{array}{l}1.7 \text { to } 79.4^{\circ} \mathrm{C}, \pm 0.28^{\circ} \mathrm{C} \\
\text { (35 to } 175^{\circ} \mathrm{F}, \pm 0.5^{\circ} \mathrm{F} \text { ) }\end{array}$ & \\
\hline $\begin{array}{l}\text { Evaporator inlet } \\
\text { pressure }\end{array}$ & $\begin{array}{l}\text { Omega Pressure Transducer } \\
\text { PX409 absolute pressure sensor }\end{array}$ & $\begin{array}{l}0 \text { to } 250 \mathrm{psiA} \text {, } \\
\pm 0.08 \% \mathrm{BSL}\end{array}$ & \multirow{2}{*}{$\begin{array}{l}\text { Used to evaluate } \\
\text { evaporator inlet } \\
\text { enthalpy for } \\
\text { refrigerant mixtures } \\
\text { with significant glide }\end{array}$} \\
\hline $\begin{array}{l}\text { Evaporator inlet } \\
\text { temperature }\end{array}$ & In-stream T-type thermocouple & $\begin{array}{l}1.7 \text { to } 79.4^{\circ} \mathrm{C}, \pm 0.28^{\circ} \mathrm{C} \\
\left(35 \text { to } 175^{\circ} \mathrm{F}, \pm 0.5^{\circ} \mathrm{F} \text { ) }\right.\end{array}$ & \\
\hline $\begin{array}{l}\text { Evaporator inlet } \\
\text { pressure }\end{array}$ & $\begin{array}{l}\text { Omega Pressure Transducer } \\
\text { PX409 absolute pressure sensor }\end{array}$ & $\begin{array}{l}0 \text { to } 250 \mathrm{psiA} \text {, } \\
\pm 0.08 \% \mathrm{BSL}\end{array}$ & \multirow{2}{*}{$\begin{array}{l}\text { Used to evaluate } \\
\text { evaporator outlet } \\
\text { enthalpy }\end{array}$} \\
\hline $\begin{array}{l}\text { Evaporator inlet } \\
\text { temperature }\end{array}$ & In-stream T-type thermocouple & $\begin{array}{l}1.7 \text { to } 79.4^{\circ} \mathrm{C}, \pm 0.28^{\circ} \mathrm{C} \\
\text { (35 to } 175^{\circ} \mathrm{F}, \pm 0.5^{\circ} \mathrm{F} \text { ) }\end{array}$ & \\
\hline $\begin{array}{l}\text { Refrigerant mass } \\
\text { flow rate }\end{array}$ & $\begin{array}{l}\text { Micro Motion Elite CMF025 } \\
\text { Coriolis mass flow meter }\end{array}$ & $\begin{array}{l}0 \text { to } 0.19 \mathrm{~kg} / \mathrm{s} \\
(0 \text { to } 25 \mathrm{lb} / \mathrm{min}) \\
\pm 0.1 \% \text { of rate }\end{array}$ & \\
\hline Compressor power & Power meter & $0-4 \mathrm{~kW}, \pm 0.2 \%$ reading & \\
\hline Outdoor fan power & Power meter & $0-4 \mathrm{~kW}, \pm 0.2 \%$ reading & \\
\hline Indoor unit power & Power meter & $0-1 \mathrm{~kW}, \pm 0.2 \%$ reading & \\
\hline
\end{tabular}


Table C.2. R-410A unit experimental setup instrumentation

\begin{tabular}{|c|c|c|c|}
\hline Data & Instrument & Range and accuracy & Comments \\
\hline $\begin{array}{l}\text { Indoor unit air inlet } \\
\text { temperature }\end{array}$ & Class-A RTD & $\begin{array}{l}-30 \text { to } 300^{\circ} \mathrm{C}, \pm 0.15^{\circ} \mathrm{C} \\
\left(-22 \text { to } 572^{\circ} \mathrm{F}, \pm 0.27^{\circ} \mathrm{F}\right)\end{array}$ & \multirow{4}{*}{$\begin{array}{l}\text { Using aspirated } \\
\text { sampling } \\
\text { temperature tree }\end{array}$} \\
\hline $\begin{array}{l}\text { Indoor unit air inlet } \\
\text { wet bulb temperature }\end{array}$ & $\begin{array}{l}\text { Wetted hygrometer with Class-A } \\
\text { RTD }\end{array}$ & $\begin{array}{l}4 \text { to } 60^{\circ} \mathrm{C}, \pm 0.15^{\circ} \mathrm{C} \\
\left(39.2 \text { to } 140^{\circ} \mathrm{F}, \pm 0.27^{\circ} \mathrm{F}\right)\end{array}$ & \\
\hline $\begin{array}{l}\text { Indoor unit air outlet } \\
\text { temperature }\end{array}$ & Class-A RTD & $\begin{array}{l}-30 \text { to } 300^{\circ} \mathrm{C}, \pm 0.15^{\circ} \mathrm{C} \\
\left(-22 \text { to } 572^{\circ} \mathrm{F}, \pm 0.27^{\circ} \mathrm{F}\right)\end{array}$ & \\
\hline $\begin{array}{l}\text { Indoor unit air outlet } \\
\text { wet bulb temperature }\end{array}$ & $\begin{array}{l}\text { Wetted hygrometer with Class-A } \\
\text { RTD }\end{array}$ & $\begin{array}{l}4 \text { to } 60^{\circ} \mathrm{C}, \pm 0.15^{\circ} \mathrm{C} \\
\left(39.2 \text { to } 140^{\circ} \mathrm{F}, \pm 0.27^{\circ} \mathrm{F}\right)\end{array}$ & \\
\hline Condensate rate & Sartorius Midrics electronic scale & $\begin{array}{l}0 \text { to } 30 \mathrm{~kg}, \\
2 \text { g readability }\end{array}$ & \\
\hline Airflow rate & Code evaluator & 100 to $3000 \mathrm{cfm}, \pm 0.4 \%$ & \multirow{4}{*}{$\begin{array}{l}\text { Air mass flow rate } \\
\text { measurement }\end{array}$} \\
\hline $\begin{array}{l}\text { nozzle upstream } \\
\text { barometric pressure }\end{array}$ & $\begin{array}{l}\text { Setra model } 278 \text { barometric } \\
\text { pressure sensor }\end{array}$ & $\begin{array}{l}800 \text { to } 1100 \mathrm{hPa} / \mathrm{mb} \text {, } \\
\pm 0.6 \mathrm{hPa} / \mathrm{mb}\end{array}$ & \\
\hline $\begin{array}{l}\text { Temperature } \\
\text { upstream of the } \\
\text { nozzle }\end{array}$ & T-type thermocouple & $\begin{array}{l}-30 \text { to } 300^{\circ} \mathrm{C}, \pm 0.15^{\circ} \mathrm{C} \\
\left(-22 \text { to } 572^{\circ} \mathrm{F}, \pm 0.27^{\circ} \mathrm{F}\right)\end{array}$ & \\
\hline $\begin{array}{l}\text { Pressure drop across } \\
\text { the nozzle }\end{array}$ & $\begin{array}{l}\text { Setra Model } 239 \text { differential } \\
\text { pressure sensor }\end{array}$ & $\begin{array}{l}0 \text { to } 5 \text { in. } \mathrm{H}_{2} \mathrm{O} \\
\pm 0.073 \% \mathrm{FS}\end{array}$ & \\
\hline Liquid line pressure & $\begin{array}{l}\text { Omega Pressure Transducer } \\
\text { PX409 absolute pressure sensor }\end{array}$ & $\begin{array}{l}0-750 \mathrm{psiA} \\
\pm 0.08 \% \mathrm{BSL}\end{array}$ & \multirow{2}{*}{$\begin{array}{l}\text { Used to evaluate } \\
\text { evaporator inlet } \\
\text { enthalpy }\end{array}$} \\
\hline $\begin{array}{l}\text { Liquid line } \\
\text { temperature }\end{array}$ & In-stream T-type thermocouple & $\begin{array}{l}-30 \text { to } 300^{\circ} \mathrm{C}, \pm 0.15^{\circ} \mathrm{C} \\
\left(-22 \text { to } 572^{\circ} \mathrm{F}, \pm 0.27^{\circ} \mathrm{F}\right)\end{array}$ & \\
\hline $\begin{array}{l}\text { Evaporator inlet } \\
\text { pressure }\end{array}$ & $\begin{array}{l}\text { Omega Pressure Transducer } \\
\text { PX409 absolute pressure sensor }\end{array}$ & $\begin{array}{l}0 \text { to } 250 \mathrm{psiA} \text {, } \\
\pm 0.08 \% \mathrm{BSL}\end{array}$ & \multirow{2}{*}{$\begin{array}{l}\text { Used to evaluate } \\
\text { evaporator inlet } \\
\text { enthalpy for } \\
\text { refrigerant mixtures } \\
\text { with significant glide }\end{array}$} \\
\hline $\begin{array}{l}\text { Evaporator inlet } \\
\text { temperature }\end{array}$ & In-stream T-type thermocouple & $\begin{array}{l}-30 \text { to } 300^{\circ} \mathrm{C}, \pm 0.15^{\circ} \mathrm{C} \\
\left(-22 \text { to } 572^{\circ} \mathrm{F}, \pm 0.27^{\circ} \mathrm{F}\right)\end{array}$ & \\
\hline $\begin{array}{l}\text { Evaporator inlet } \\
\text { pressure }\end{array}$ & $\begin{array}{l}\text { Omega Pressure Transducer } \\
\text { PX409 absolute pressure sensor }\end{array}$ & $\begin{array}{l}0 \text { to } 250 \mathrm{psiA} \text {, } \\
\pm 0.08 \% \mathrm{BSL}\end{array}$ & \multirow{2}{*}{$\begin{array}{l}\text { Used to evaluate } \\
\text { evaporator outlet } \\
\text { enthalpy }\end{array}$} \\
\hline $\begin{array}{l}\text { Evaporator inlet } \\
\text { temperature }\end{array}$ & In-stream T-type thermocouple & $\begin{array}{l}-30 \text { to } 300^{\circ} \mathrm{C}, \pm 0.15^{\circ} \mathrm{C} \\
\left(-22 \text { to } 572^{\circ} \mathrm{F}, \pm 0.27^{\circ} \mathrm{F}\right)\end{array}$ & \\
\hline $\begin{array}{l}\text { Refrigerant mass } \\
\text { flow rate }\end{array}$ & $\begin{array}{l}\text { Micro Motion Elite CMF025 } \\
\text { Coriolis mass flow meter }\end{array}$ & $\begin{array}{l}0 \text { to } 0.19 \mathrm{~kg} / \mathrm{s} \\
(0 \text { to } 25 \mathrm{lb} / \mathrm{min}) \\
\pm 0.1 \% \text { of rate }\end{array}$ & \\
\hline Compressor power & Power meter & $0-4 \mathrm{~kW}, \pm 0.2 \%$ reading & \\
\hline Outdoor fan power & Power meter & $0-4 \mathrm{~kW}, \pm 0.2 \%$ reading & \\
\hline Indoor unit power & Power meter & $0-1 \mathrm{~kW}, \pm 0.2 \%$ reading & \\
\hline
\end{tabular}


C-10 
APPENDIX D. DETAILED R-22 TEST DATA 



\section{APPENDIX D. DETAILED R-22 TEST DATA}

This appendix provides additional details of the testing documented in Section 6.1.

Figure D.1 shows the COP for each refrigerant at each test condition, including the rerun of R-22 with mineral oil, the results of R-22 with POE oil, and the results for R-290 using mineral oil. Note that ORNL conducted two sets of tests with R-22, one before any other refrigerants were tested and one after all refrigerants had been tested. By comparing the results before and after testing the alternative refrigerants, it is possible to establish the performance reliability using the alternative refrigerants. The results for the first R-22 (mineral oil) run and the R-22 (mineral oil) rerun agree within $4.4 \%$ in terms of COP and within $3.6 \%$ in terms of cooling capacity for all test conditions.

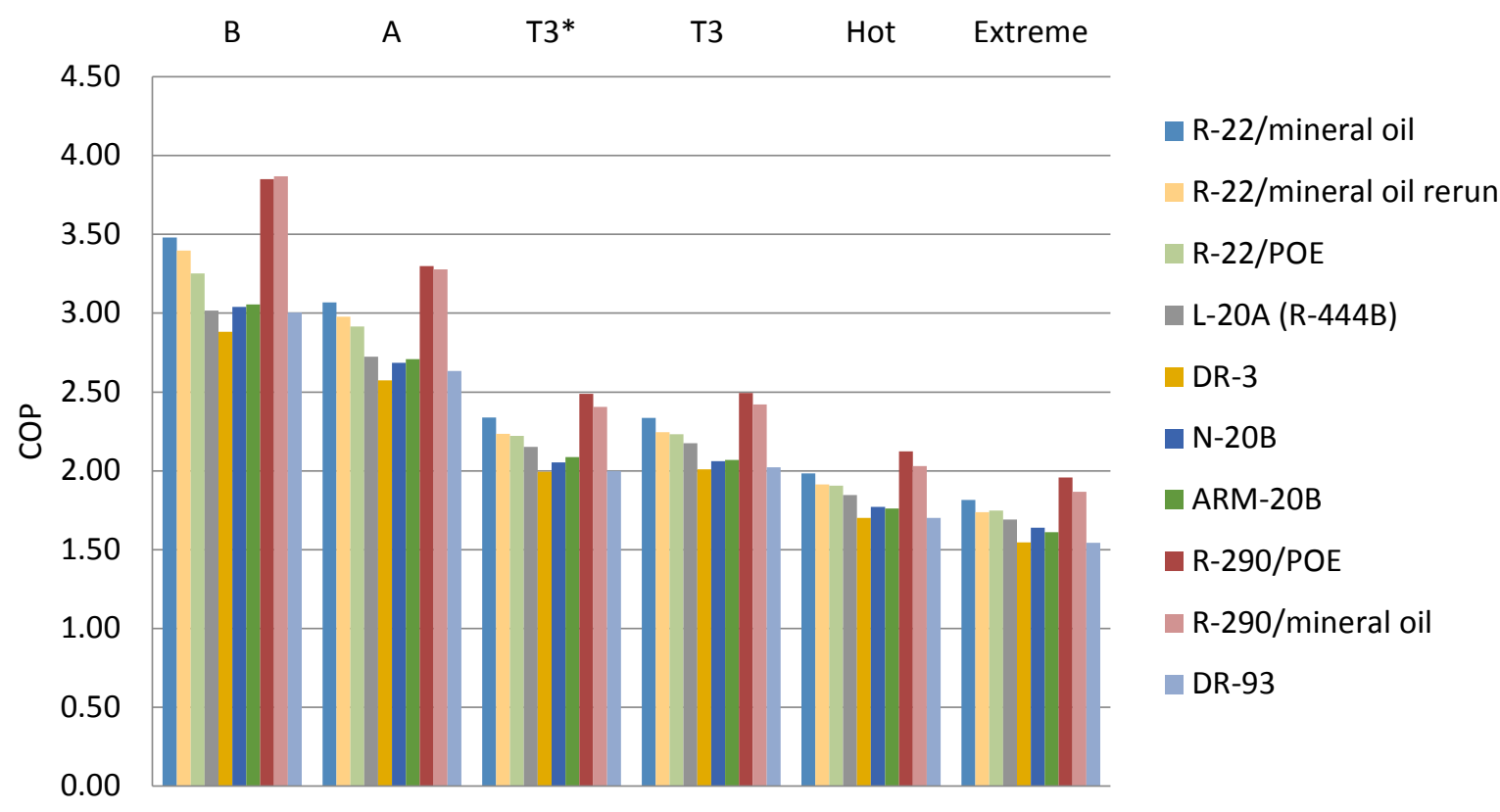

Figure D.1. COP for R-22 and its alternatives at each test condition, including the additional R-22 (mineral oil rerun and POE run) and R-290 (mineral oil run) results.

Figure D.2 shows the cooling capacity for each refrigerant at each test condition, including the additional R-22 and R-290 results. 


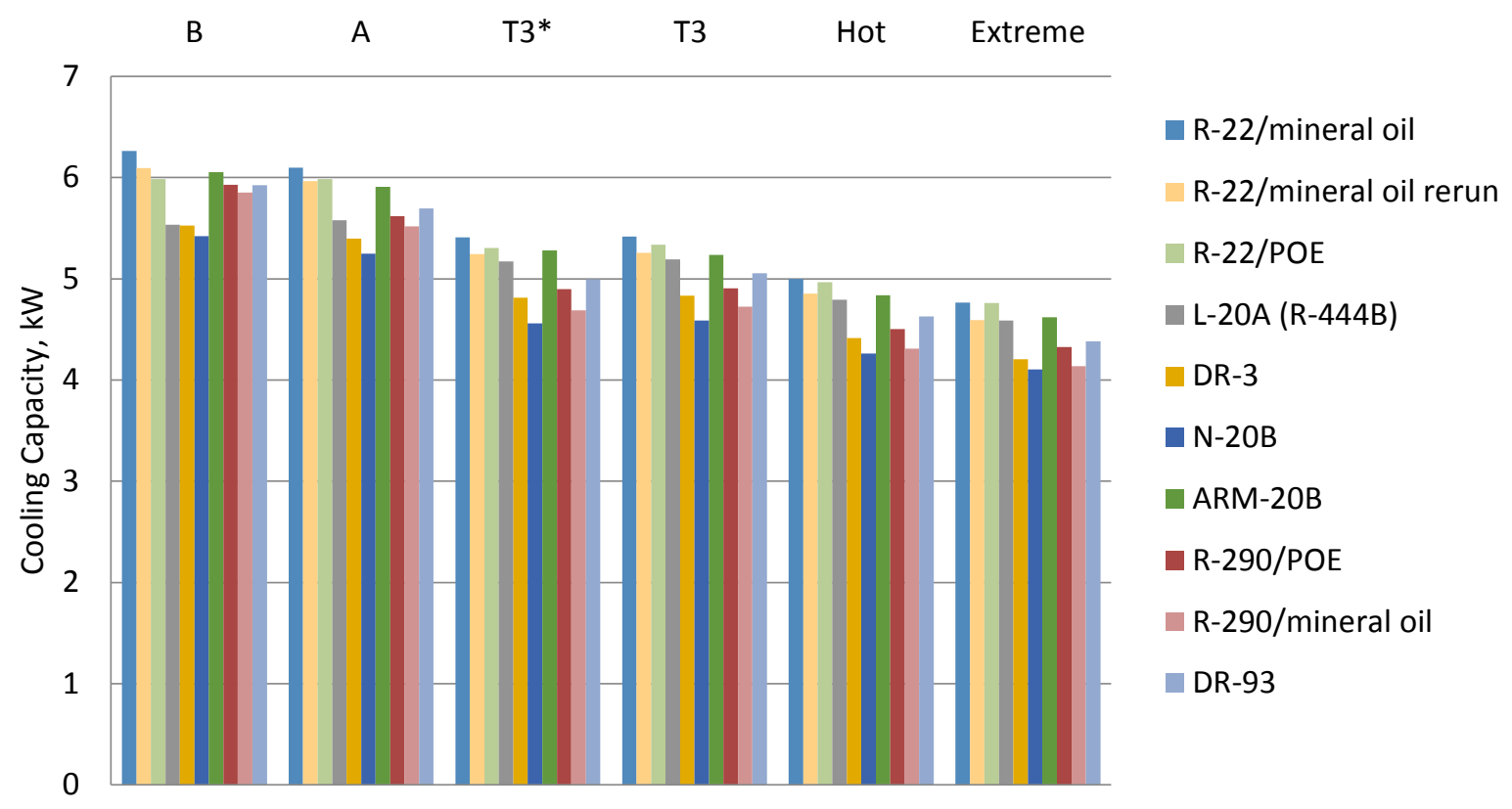

Figure D.2. Cooling capacity for R-22 and its alternatives at each test condition, including the additional R-22 (mineral oil rerun and POE run) and R-290 (mineral oil run) results.

Figure D.3 shows the COP of each refrigerant at each test condition, relative to the COP of that refrigerant at AHRI A conditions.

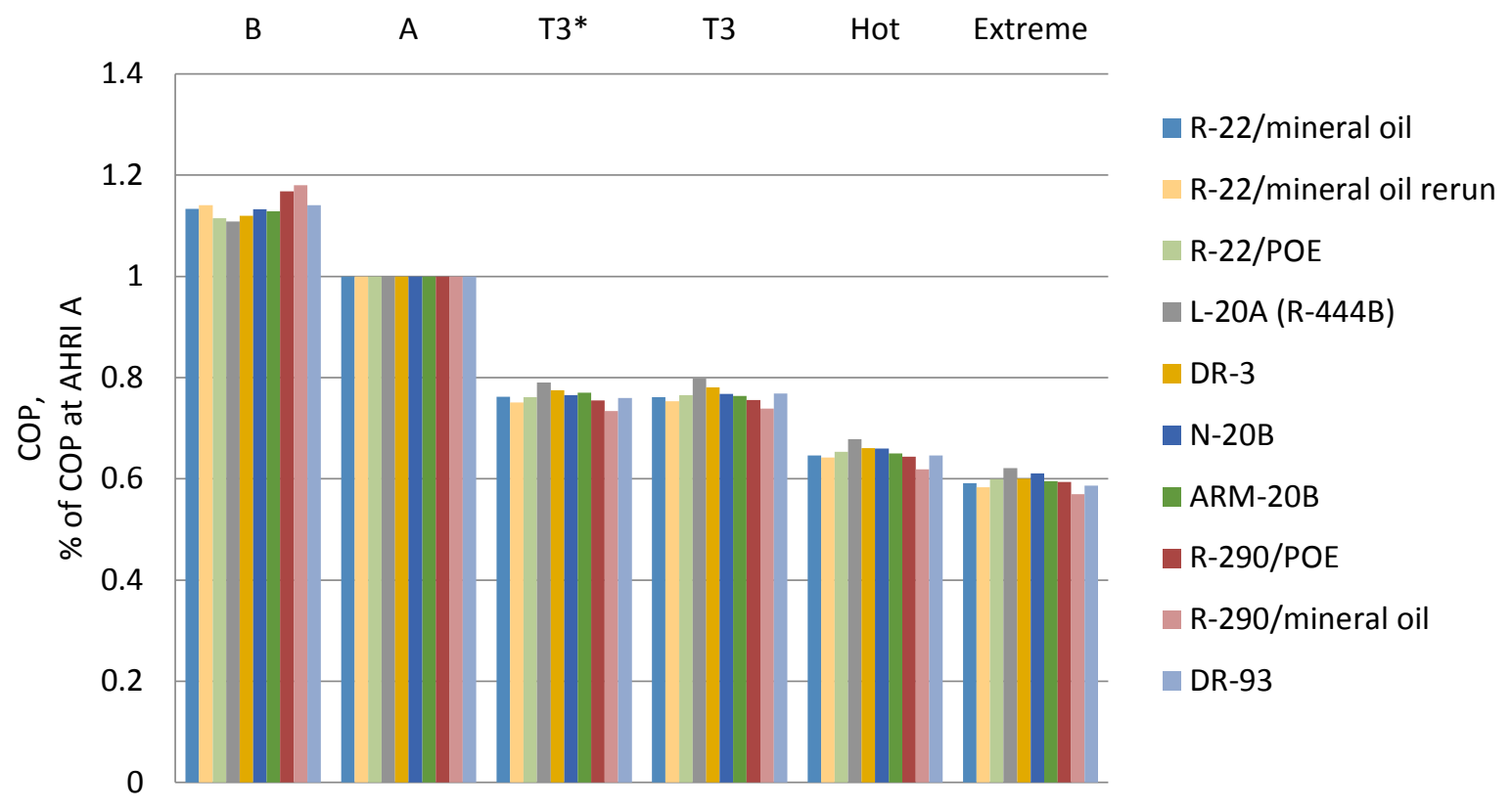

Figure D.3. COP for R-22 and its alternatives at each test condition, relative to the COP of that refrigerant at AHRI A conditions.

Figure D.4 shows the cooling capacity of each refrigerant at each test condition, relative to the cooling capacity of that refrigerant at AHRI A conditions. 


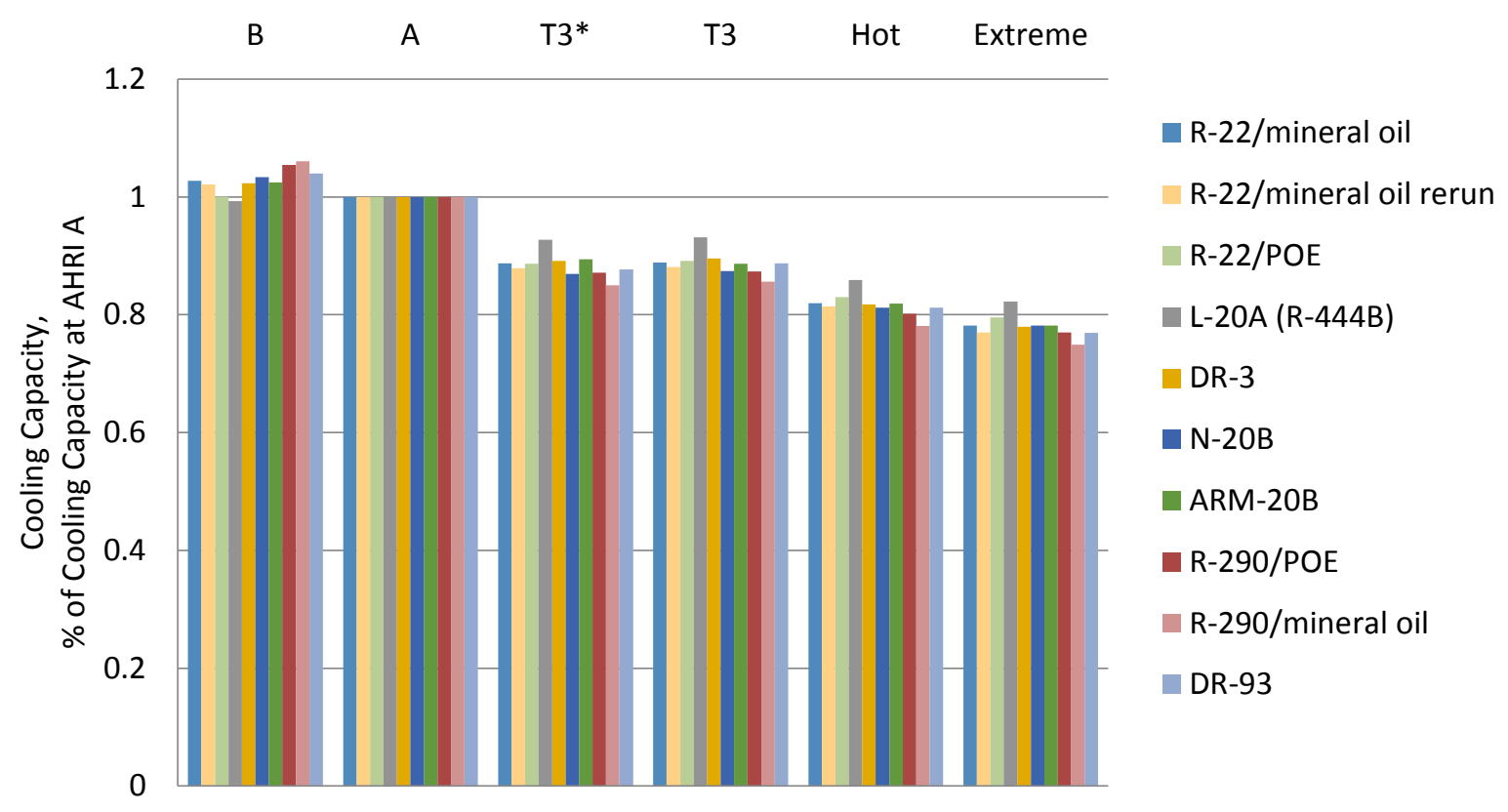

Figure D.4. Cooling capacity for R-22 and its alternatives at each test condition, relative to the cooling capacity of that refrigerant at AHRI A conditions.

Figure D.5 shows the condenser subcooling for each refrigerant under each of the test conditions.

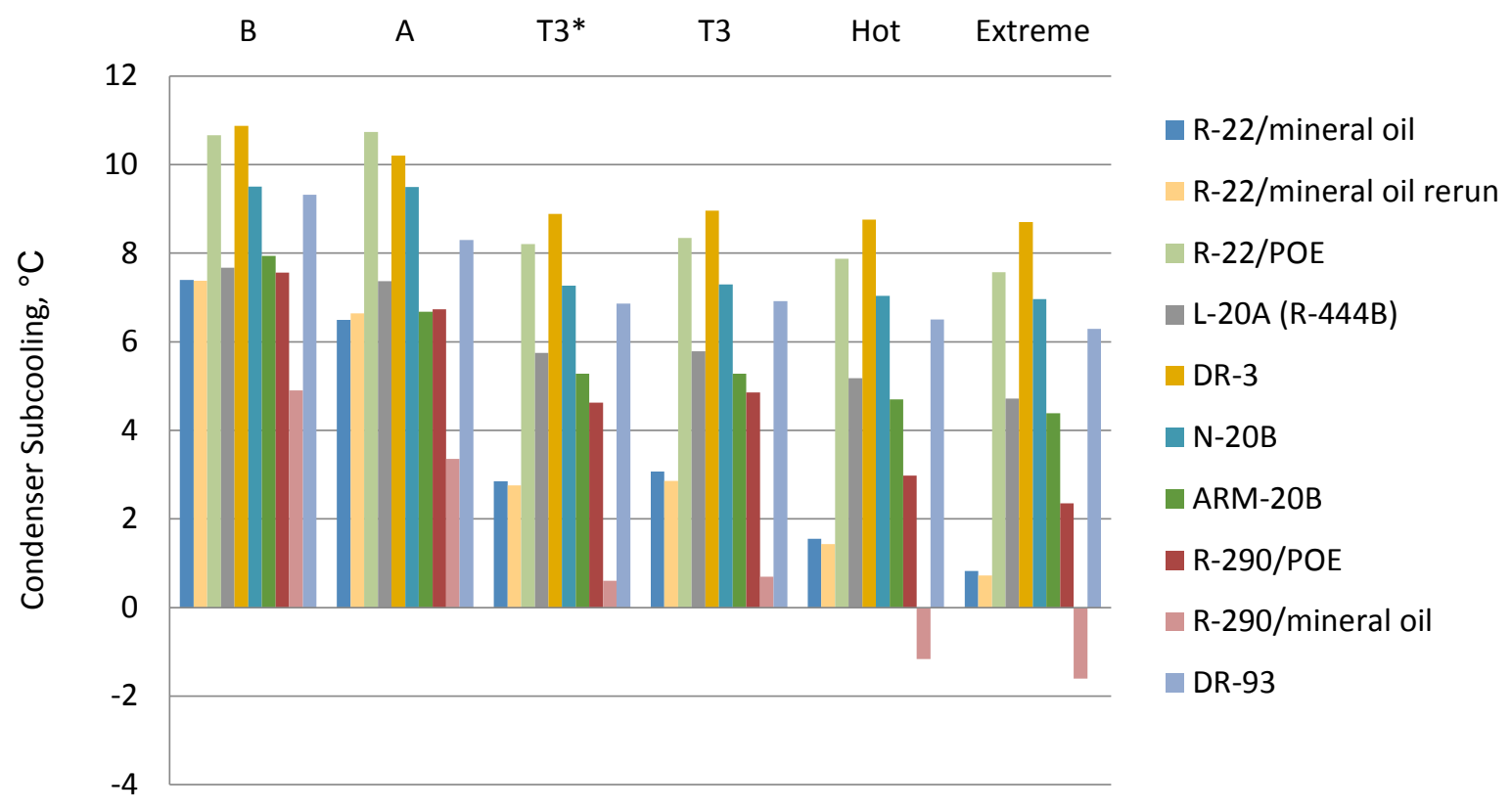

Figure D.5. Condenser subcooling for R-22 and its alternatives at each test condition.

Figure D.6 shows the evaporator superheat for each refrigerant under each of the test conditions. 


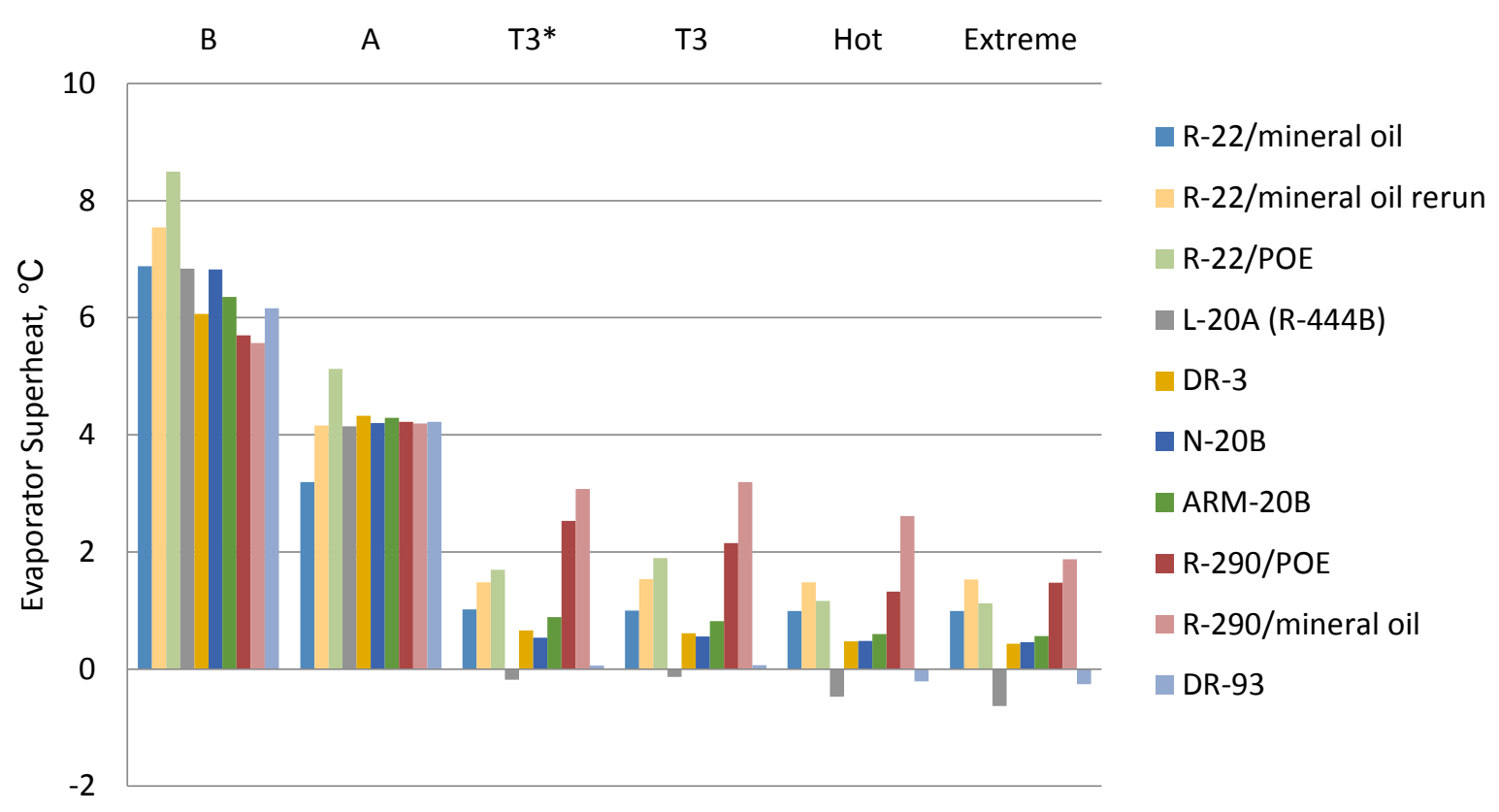

Figure D.6. Evaporator superheat for R-22 and its alternatives at each test condition.

Figure D.7 shows the compressor discharge temperature for each refrigerant under each of the test conditions.

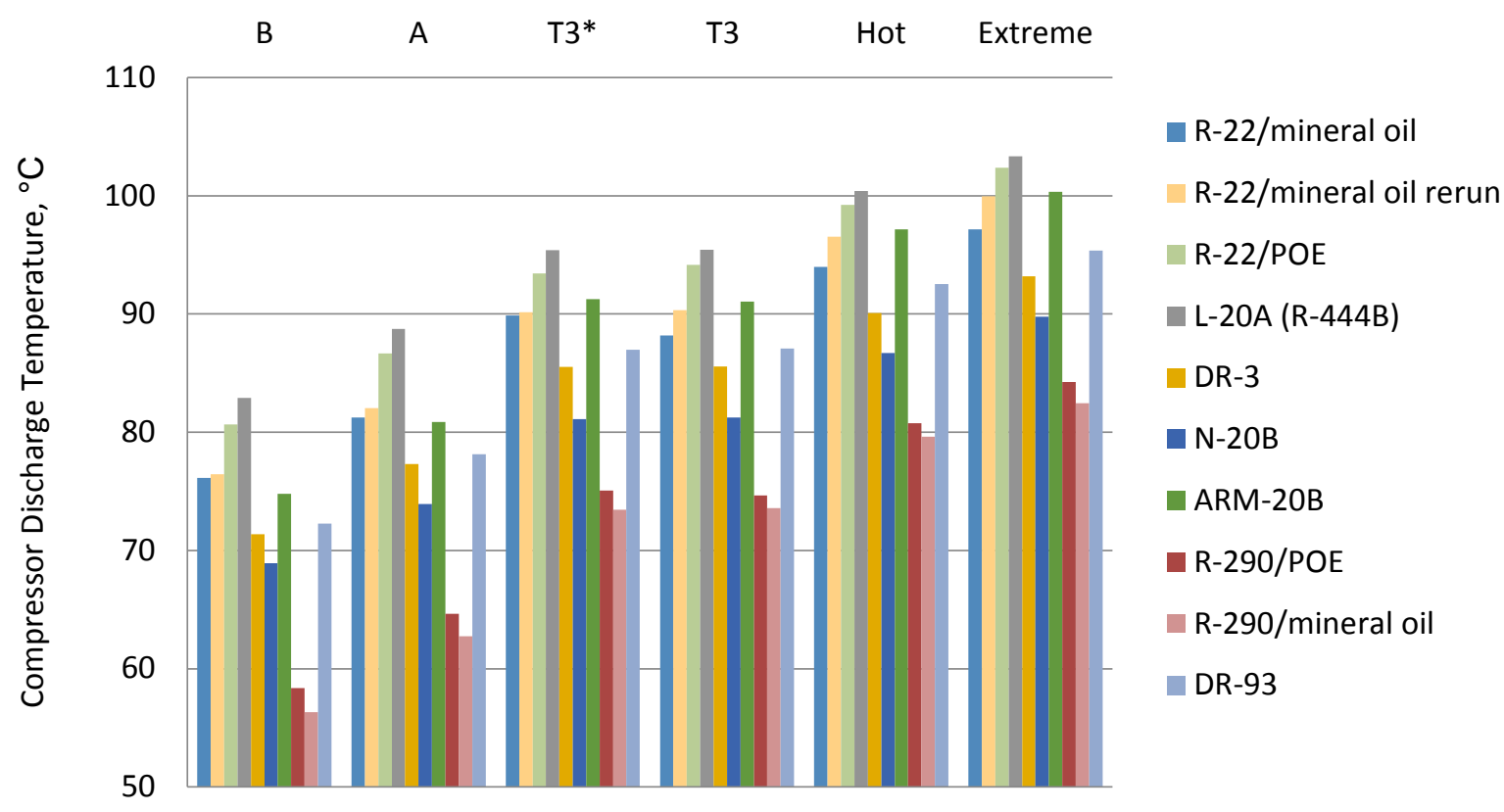

Figure D.7. Compressor discharge temperature for R-22 and its alternatives at each test condition.

Figure D.8 shows the temperature glide at the evaporator for each refrigerant under each of the test conditions. 


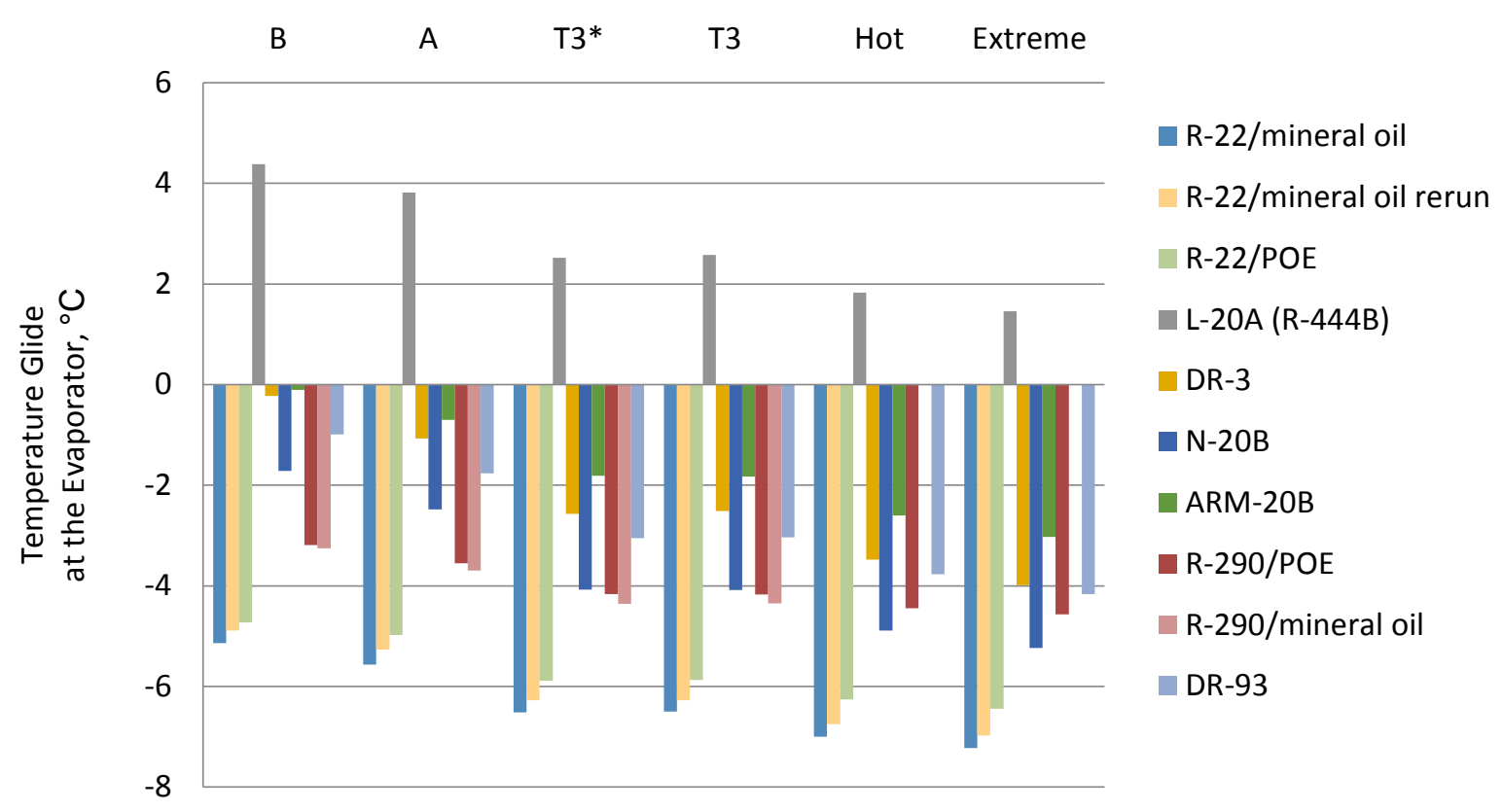

Figure D.8. Temperature glide at the evaporator for $\mathrm{R}-22$ and its alternatives at each test condition.

Figure D.9 compares the COP and capacity of the alternative refrigerants to those of R-22 under the AHRI A test conditions, with all the refrigerants using the original capillary tube from the R-22 unit. These tests were done in addition to the tests described in Section 6.1.

Performance Relative to Baseline at AHRI A Conditions $35^{\circ} \mathrm{C}\left[95^{\circ} \mathrm{F}\right]$ Outdoor and $27^{\circ} \mathrm{C}\left[80^{\circ} \mathrm{F}\right]$ Indoor

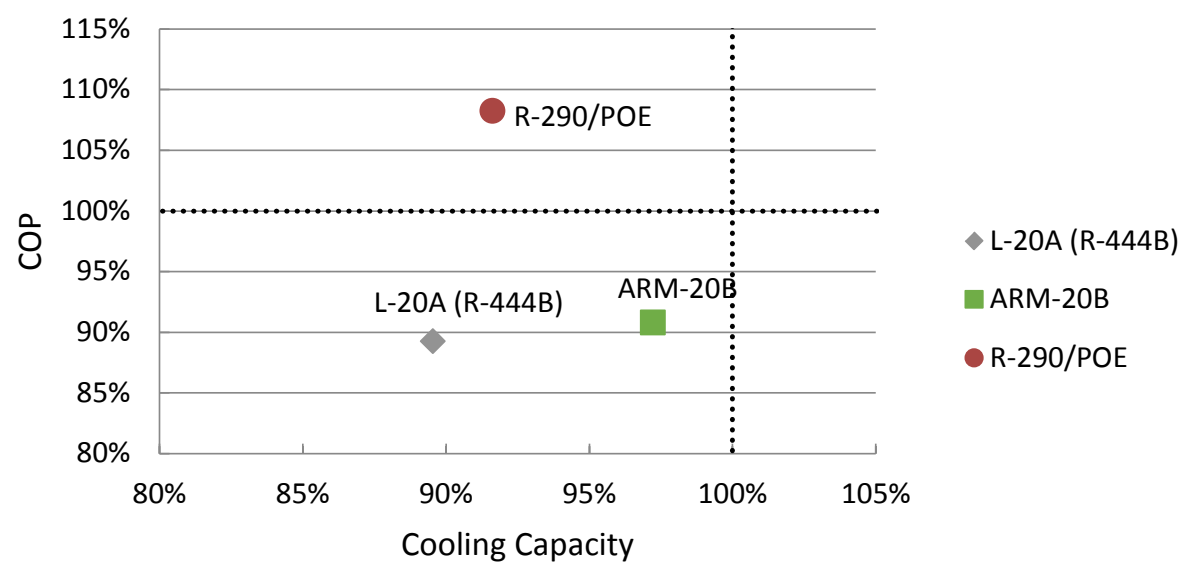

Figure D.9. Performance of alternative refrigerants compared with R-22 (mineral oil) at AHRI A test conditions (outdoor temperature $35^{\circ} \mathrm{C}$ and indoor temperature $27^{\circ} \mathrm{C}$ ), all using the original capillary tube from the $\mathrm{R}-22$ unit.

Figure D.10 compares the COP and capacity of the alternative refrigerants to those of R-22 under the ISO T3 test conditions, with all the refrigerants using the original capillary tube from the R-22 unit. 
Performance Relative to Baseline at ISO T3 Conditions $46^{\circ} \mathrm{C}\left[114.8^{\circ} \mathrm{F}\right]$ Outdoor and $29^{\circ} \mathrm{C}\left[84.2^{\circ} \mathrm{F}\right]$ Indoor

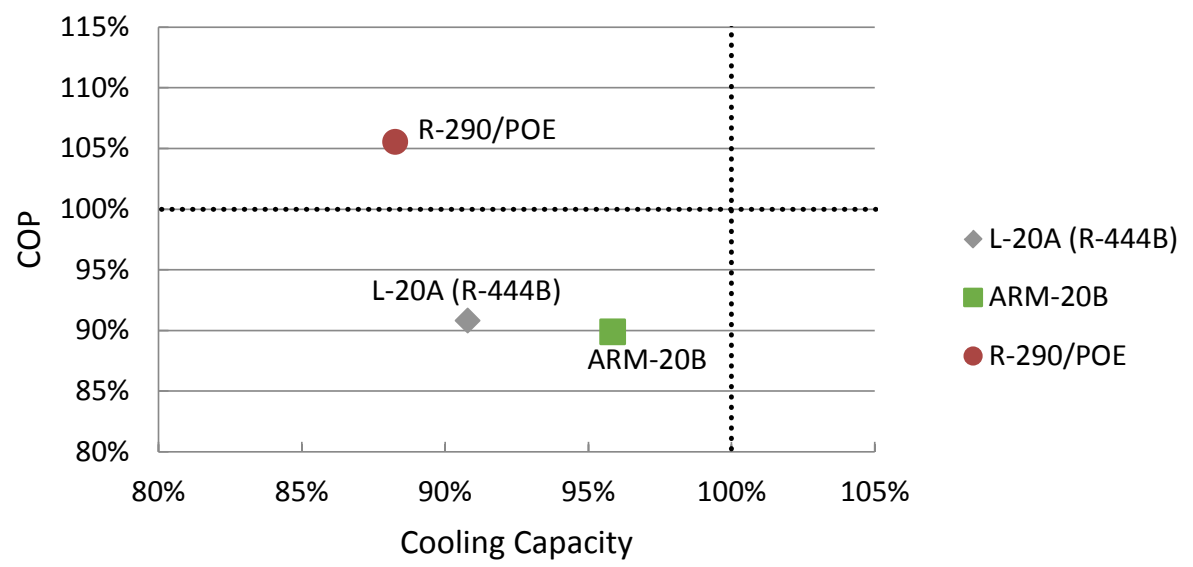

Figure D.10. Performance of alternative refrigerants compared with R-22 (mineral oil) at ISO T3 test conditions (outdoor temperature $46^{\circ} \mathrm{C}$ and indoor temperature $29^{\circ} \mathrm{C}$ ), all using the original capillary tube from the R-22 unit.

Figure D.11 compares the COP and capacity of the alternative refrigerants to R-22 under Extreme test conditions, with all the refrigerants using the original capillary tube from the R-22 unit.

Performance Relative to Baseline at Extreme Conditions $55^{\circ} \mathrm{C}\left[131^{\circ} \mathrm{F}\right]$ Outdoor and $29^{\circ} \mathrm{C}\left[84.2^{\circ} \mathrm{F}\right]$ Indoor

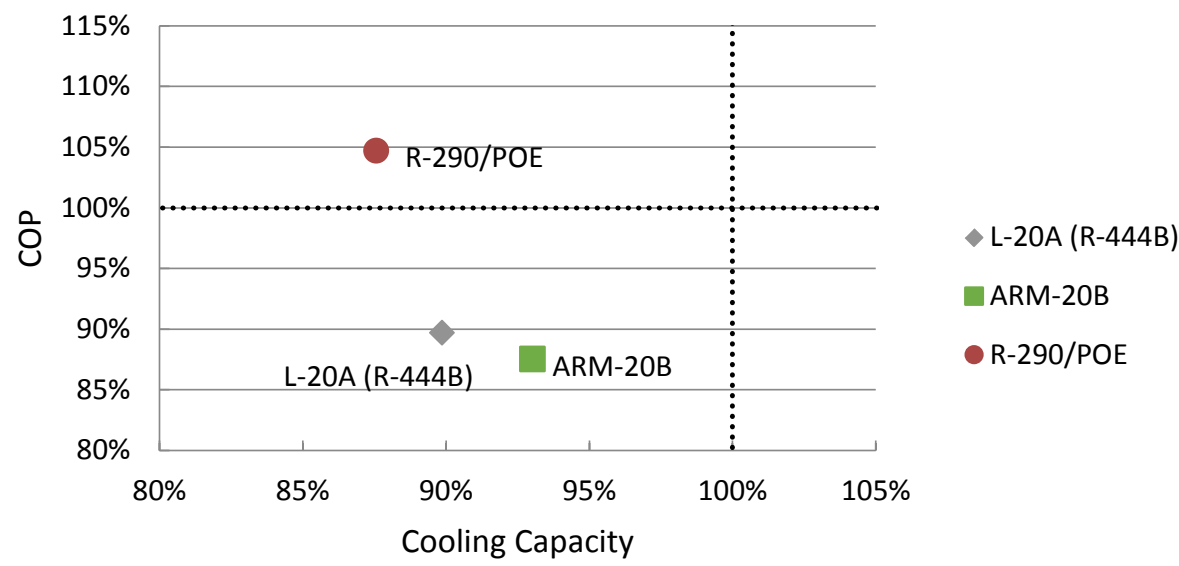

Figure D.11. Performance of alternative refrigerants compared with R-22 (mineral oil) at Extreme test conditions (outdoor temperature $55^{\circ} \mathrm{C}$ and indoor temperature $29^{\circ} \mathrm{C}$ ), all using the original capillary tube from the R-22 unit.

Table D.1 shows additional test data, including

- $\quad$ air-side cooling capacity

- air-side COP 
- liquid line temperature and pressure

- evaporator inlet temperature and pressure

- evaporator outlet temperature and pressure

- compressor suction temperature

- saturation temperature at four different points within the cycle

- refrigerant mass flow rate

- capillary tube length

- refrigerant charge

Table D.2 shows the additional test data for the test runs with the original capillary tube. 
Table D.1. Additional test data for the R-22 unit

\begin{tabular}{|c|c|c|c|c|c|c|c|}
\hline & \multirow{2}{*}{ Refrigerant } & \multicolumn{6}{|c|}{ Test conditions } \\
\hline & & B & A & T3* & T3 & Hot & Extreme \\
\hline \multirow{10}{*}{$\begin{array}{l}\text { Cooling } \\
\text { Capacity (air- } \\
\text { side), kW }\end{array}$} & R-22/mineral oil & 6.26 & 6.10 & 5.41 & 5.42 & 5.00 & 4.76 \\
\hline & $\mathrm{R}-22 /$ mineral oil rerun & 6.09 & 5.97 & 5.24 & 5.26 & 4.86 & 4.59 \\
\hline & $\mathrm{R}-22 / \mathrm{POE}$ & 5.99 & 5.98 & 5.31 & 5.34 & 4.96 & 4.76 \\
\hline & L-20A (R-444B) & 5.53 & 5.58 & 5.17 & 5.19 & 4.79 & 4.59 \\
\hline & DR-3 & 5.52 & 5.40 & 4.81 & 4.83 & 4.41 & 4.21 \\
\hline & $\mathrm{N}-20 \mathrm{~B}$ & 5.42 & 5.25 & 4.56 & 4.59 & 4.26 & 4.10 \\
\hline & ARM-20B & 6.05 & 5.91 & 5.28 & 5.24 & 4.84 & 4.62 \\
\hline & R-290/POE & 5.93 & 5.62 & 4.90 & 4.91 & 4.50 & 4.33 \\
\hline & R-290/mineral oil & 5.85 & 5.52 & 4.69 & 4.72 & 4.31 & 4.14 \\
\hline & DR-93 & 5.92 & 5.70 & 4.99 & 5.05 & 4.63 & 4.38 \\
\hline \multirow{10}{*}{ COP (air-side) } & R-22/mineral oil & 3.48 & 3.07 & 2.34 & 2.34 & 1.98 & 1.82 \\
\hline & $\mathrm{R}-22 /$ mineral oil rerun & 3.40 & 2.98 & 2.24 & 2.24 & 1.91 & 1.74 \\
\hline & $\mathrm{R}-22 / \mathrm{POE}$ & 3.25 & 2.92 & 2.22 & 2.23 & 1.91 & 1.75 \\
\hline & L-20A (R-444B) & 3.02 & 2.72 & 2.15 & 2.17 & 1.85 & 1.69 \\
\hline & DR-3 & 2.88 & 2.57 & 1.99 & 2.01 & 1.70 & 1.55 \\
\hline & $\mathrm{N}-20 \mathrm{~B}$ & 3.04 & 2.68 & 2.05 & 2.06 & 1.77 & 1.64 \\
\hline & ARM-20B & 3.06 & 2.71 & 2.09 & 2.07 & 1.76 & 1.61 \\
\hline & R-290/POE & 3.85 & 3.30 & 2.49 & 2.49 & 2.12 & 1.96 \\
\hline & R-290/mineral oil & 3.87 & 3.28 & 2.41 & 2.42 & 2.03 & 1.87 \\
\hline & DR-93 & 3.00 & 2.63 & 2.00 & 2.02 & 1.70 & 1.54 \\
\hline \multirow{10}{*}{$\begin{array}{c}\text { Condenser } \\
\text { Subcooling, } \\
{ }^{\circ} \mathrm{C}\end{array}$} & R-22/mineral oil & 7.39 & 6.49 & 2.85 & 3.07 & 1.55 & 0.83 \\
\hline & $\mathrm{R}-22 /$ mineral oil rerun & 7.38 & 6.64 & 2.76 & 2.86 & 1.43 & 0.72 \\
\hline & $\mathrm{R}-22 / \mathrm{POE}$ & 10.66 & 10.74 & 8.21 & 8.35 & 7.87 & 7.58 \\
\hline & L-20A (R-444B) & 7.67 & 7.37 & 5.75 & 5.79 & 5.18 & 4.72 \\
\hline & DR-3 & 10.87 & 10.20 & 8.89 & 8.96 & 8.76 & 8.70 \\
\hline & $N-20 B$ & 9.50 & 9.49 & 7.27 & 7.30 & 7.04 & 6.96 \\
\hline & ARM-20B & 7.94 & 6.68 & 5.28 & 5.28 & 4.70 & 4.39 \\
\hline & $\mathrm{R}-290 / \mathrm{POE}$ & 7.56 & 6.73 & 4.63 & 4.86 & 2.98 & 2.35 \\
\hline & R-290/mineral oil & 4.91 & 3.36 & 0.61 & 0.70 & -1.16 & -1.61 \\
\hline & DR-93 & 9.32 & 8.30 & 6.86 & 6.92 & 6.50 & 6.30 \\
\hline
\end{tabular}


Table D.1. (continued)

\begin{tabular}{|c|c|c|c|c|c|c|c|}
\hline & \multirow{2}{*}{ Refrigerant } & \multicolumn{6}{|c|}{ Test conditions } \\
\hline & & $\mathrm{B}$ & A & $\mathrm{T} 3 *$ & T3 & Hot & Extreme \\
\hline \multirow{10}{*}{$\begin{array}{c}\text { Evaporator } \\
\text { Superheat, }{ }^{\circ} \mathrm{C}\end{array}$} & R-22/mineral oil & 6.88 & 3.19 & 1.02 & 1.00 & 0.99 & 0.99 \\
\hline & $\mathrm{R}-22 /$ mineral oil rerun & 7.54 & 4.16 & 1.48 & 1.54 & 1.48 & 1.53 \\
\hline & $\mathrm{R}-22 / \mathrm{POE}$ & 8.49 & 5.13 & 1.70 & 1.90 & 1.17 & 1.12 \\
\hline & L-20A (R-444B) & 6.83 & 4.14 & -0.18 & -0.13 & -0.47 & -0.63 \\
\hline & DR-3 & 6.06 & 4.33 & 0.66 & 0.61 & 0.47 & 0.43 \\
\hline & N-20B & 6.83 & 4.20 & 0.54 & 0.55 & 0.48 & 0.46 \\
\hline & ARM-20B & 6.35 & 4.29 & 0.89 & 0.82 & 0.59 & 0.57 \\
\hline & R-290/POE & 5.70 & 4.22 & 2.53 & 2.15 & 1.32 & 1.47 \\
\hline & R-290/mineral oil & 5.57 & 4.19 & 3.08 & 3.19 & 2.62 & 1.88 \\
\hline & DR-93 & 6.16 & 4.22 & 0.06 & 0.07 & -0.21 & -0.26 \\
\hline \multirow{10}{*}{$\begin{array}{l}\text { Compressor } \\
\text { Discharge } \\
\text { Temperature, } \\
{ }^{\circ} \mathrm{C}\end{array}$} & $\mathrm{R}-22 /$ mineral oil & 76.2 & 81.2 & 89.9 & 88.2 & 94.0 & 97.2 \\
\hline & $\mathrm{R}-22 /$ mineral oil rerun & 76.4 & 82.0 & 90.2 & 90.3 & 96.5 & 99.9 \\
\hline & $\mathrm{R}-22 / \mathrm{POE}$ & 80.7 & 86.7 & 93.4 & 94.1 & 99.2 & 102.4 \\
\hline & L-20A (R-444B) & 82.9 & 88.7 & 95.4 & 95.4 & 100.4 & 103.3 \\
\hline & DR-3 & 71.4 & 77.3 & 85.5 & 85.6 & 90.1 & 93.2 \\
\hline & $\mathrm{N}-20 \mathrm{~B}$ & 68.9 & 73.9 & 81.1 & 81.2 & 86.7 & 89.8 \\
\hline & ARM-20B & 74.8 & 80.9 & 91.3 & 91.0 & 97.2 & 100.3 \\
\hline & R-290/POE & 58.4 & 64.6 & 75.1 & 74.7 & 80.8 & 84.3 \\
\hline & R-290/mineral oil & 56.3 & 62.7 & 73.4 & 73.6 & 79.6 & 82.5 \\
\hline & DR-93 & 72.3 & 78.2 & 87.0 & 87.1 & 92.5 & 95.4 \\
\hline \multirow{10}{*}{$\begin{array}{c}\text { Liquid Line } \\
\text { Temperature, } \\
{ }^{\circ} \mathrm{C}\end{array}$} & $\mathrm{R}-22 /$ mineral oil & 30.6 & 38.6 & 51.2 & 51.0 & 57.9 & 61.4 \\
\hline & $\mathrm{R}-22 /$ mineral oil rerun & 30.7 & 38.7 & 51.4 & 51.3 & 58.2 & 61.6 \\
\hline & $\mathrm{R}-22 / \mathrm{POE}$ & 29.4 & 36.8 & 48.0 & 48.0 & 54.2 & 57.3 \\
\hline & L-20A (R-444B) & 29.2 & 36.7 & 48.8 & 48.4 & 54.9 & 58.3 \\
\hline & DR-3 & 28.9 & 36.3 & 47.5 & 47.3 & 53.2 & 56.5 \\
\hline & $\mathrm{N}-20 \mathrm{~B}$ & 29.0 & 36.3 & 47.5 & 47.5 & 53.5 & 56.5 \\
\hline & ARM-20B & 29.6 & 37.1 & 48.6 & 48.6 & 54.8 & 58.0 \\
\hline & R-290/POE & 30.9 & 38.7 & 50.7 & 50.6 & 57.1 & 60.4 \\
\hline & R-290/mineral oil & 32.5 & 41.0 & 53.8 & 53.7 & 60.3 & 63.2 \\
\hline & DR-93 & 29.4 & 36.9 & 48.2 & 48.1 & 54.3 & 57.4 \\
\hline
\end{tabular}


Table D.1. (continued)

\begin{tabular}{|c|c|c|c|c|c|c|c|}
\hline & \multirow{2}{*}{ Refrigerant } & \multicolumn{6}{|c|}{ Test conditions } \\
\hline & & $\mathrm{B}$ & A & T3* & T3 & Hot & Extreme \\
\hline \multirow{10}{*}{$\begin{array}{l}\text { Liquid Line } \\
\text { Pressure, } \\
\text { MPa } \\
\text { (absolute) }\end{array}$} & R-22/mineral oil & 1.46 & 1.73 & 2.13 & 2.13 & 2.40 & 2.55 \\
\hline & $\mathrm{R}-22 /$ mineral oil rerun & 1.46 & 1.74 & 2.14 & 2.14 & 2.41 & 2.55 \\
\hline & $\mathrm{R}-22 / \mathrm{POE}$ & 1.54 & 1.84 & 2.24 & 2.24 & 2.54 & 2.69 \\
\hline & L-20A (R-444B) & 1.62 & 1.92 & 2.44 & 2.42 & 2.75 & 2.93 \\
\hline & DR-3 & 1.68 & 1.96 & 2.43 & 2.42 & 2.72 & 2.90 \\
\hline & $\mathrm{N}-20 \mathrm{~B}$ & 1.48 & 1.76 & 2.15 & 2.15 & 2.44 & 2.60 \\
\hline & ARM-20B & 1.75 & 2.03 & 2.55 & 2.55 & 2.88 & 3.06 \\
\hline & R-290/POE & 1.32 & 1.55 & 1.92 & 1.92 & 2.12 & 2.24 \\
\hline & R-290/mineral oil & 1.29 & 1.51 & 1.88 & 1.89 & 2.08 & 2.19 \\
\hline & DR-93 & 1.71 & 1.99 & 2.49 & 2.49 & 2.82 & 2.99 \\
\hline \multirow{10}{*}{$\begin{array}{c}\text { Evaporator } \\
\text { Inlet } \\
\text { Temperature, } \\
{ }^{\circ} \mathrm{C}\end{array}$} & R-22/mineral oil & 10.11 & 12.11 & 14.32 & 14.51 & 15.88 & 16.54 \\
\hline & $\mathrm{R}-22 /$ mineral oil rerun & 10.00 & 12.23 & 14.45 & 14.57 & 15.98 & 16.64 \\
\hline & $\mathrm{R}-22 / \mathrm{POE}$ & 8.96 & 11.49 & 13.72 & 13.97 & 15.20 & 15.87 \\
\hline & L-20A (R-444B) & 1.85 & 5.11 & 8.90 & 8.75 & 10.43 & 11.31 \\
\hline & DR-3 & 6.23 & 8.82 & 12.00 & 12.06 & 13.89 & 15.05 \\
\hline & $\mathrm{N}-20 \mathrm{~B}$ & 7.98 & 10.60 & 13.49 & 13.60 & 15.49 & 16.52 \\
\hline & ARM-20B & 5.35 & 7.80 & 10.51 & 10.44 & 12.11 & 12.94 \\
\hline & R-290/POE & 10.23 & 11.91 & 13.64 & 13.83 & 14.97 & 15.64 \\
\hline & R-290/mineral oil & 10.71 & 12.43 & 14.10 & 14.25 & 15.68 & 16.57 \\
\hline & DR-93 & 6.47 & 8.84 & 11.73 & 11.83 & 13.59 & 14.63 \\
\hline \multirow{10}{*}{$\begin{array}{l}\text { Evaporator } \\
\text { Inlet } \\
\text { Pressure, } \\
\mathrm{MPa} \\
\text { (absolute) }\end{array}$} & $\mathrm{R}-22 /$ mineral oil & 0.686 & 0.726 & 0.773 & 0.778 & 0.808 & 0.823 \\
\hline & $\mathrm{R}-22 /$ mineral oil rerun & 0.681 & 0.728 & 0.776 & 0.779 & 0.810 & 0.825 \\
\hline & $\mathrm{R}-22 / \mathrm{POE}$ & 0.661 & 0.714 & 0.761 & 0.767 & 0.795 & 0.810 \\
\hline & L-20A (R-444B) & 0.605 & 0.666 & 0.738 & 0.735 & 0.766 & 0.783 \\
\hline & DR-3 & 0.675 & 0.720 & 0.775 & 0.777 & 0.809 & 0.829 \\
\hline & $\mathrm{N}-20 \mathrm{~B}$ & 0.625 & 0.672 & 0.722 & 0.724 & 0.759 & 0.778 \\
\hline & ARM-20B & 0.720 & 0.769 & 0.821 & 0.820 & 0.853 & 0.870 \\
\hline & R-290/POE & 0.643 & 0.674 & 0.708 & 0.712 & 0.734 & 0.748 \\
\hline & R-290/mineral oil & 0.648 & 0.680 & 0.713 & 0.716 & 0.743 & 0.762 \\
\hline & DR-93 & 0.704 & 0.751 & 0.806 & 0.809 & 0.845 & 0.867 \\
\hline
\end{tabular}


Table D.1. (continued)

\begin{tabular}{|c|c|c|c|c|c|c|c|}
\hline & \multirow{2}{*}{ Refrigerant } & \multicolumn{6}{|c|}{ Test conditions } \\
\hline & & B & A & $\mathrm{T} 3 *$ & T3 & Hot & Extreme \\
\hline \multirow{10}{*}{$\begin{array}{c}\text { Evaporator } \\
\text { Outlet } \\
\text { Temperature, } \\
{ }^{\circ} \mathrm{C}\end{array}$} & R-22/mineral oil & 11.98 & 9.78 & 8.81 & 9.02 & 9.81 & 10.21 \\
\hline & $\mathrm{R}-22 /$ mineral oil rerun & 12.68 & 11.13 & 9.60 & 9.80 & 10.63 & 11.08 \\
\hline & $\mathrm{R}-22 / \mathrm{POE}$ & 12.78 & 11.72 & 9.56 & 10.04 & 10.14 & 10.57 \\
\hline & L-20A (R-444B) & 12.98 & 13.04 & 11.29 & 11.24 & 11.85 & 12.21 \\
\hline & DR-3 & 12.75 & 12.79 & 10.81 & 10.87 & 11.55 & 12.12 \\
\hline & N-20B & 13.21 & 12.49 & 10.14 & 10.26 & 11.23 & 11.87 \\
\hline & ARM-20B & 12.11 & 11.94 & 10.19 & 10.04 & 10.75 & 11.13 \\
\hline & R-290/POE & 12.89 & 12.71 & 12.15 & 12.00 & 12.02 & 12.70 \\
\hline & R-290/mineral oil & 12.95 & 12.87 & 12.77 & 13.05 & 13.54 & 13.57 \\
\hline & DR-93 & 12.22 & 11.88 & 9.31 & 9.44 & 10.18 & 10.76 \\
\hline \multirow{10}{*}{$\begin{array}{c}\text { Evaporator } \\
\text { Outlet } \\
\text { Pressure, } \\
\text { MPa } \\
\text { (absolute) }\end{array}$} & R-22/mineral oil & 0.586 & 0.614 & 0.637 & 0.641 & 0.657 & 0.665 \\
\hline & $\mathrm{R}-22 /$ mineral oil rerun & 0.587 & 0.621 & 0.643 & 0.646 & 0.664 & 0.672 \\
\hline & $\mathrm{R}-22 / \mathrm{POE}$ & 0.571 & 0.614 & 0.638 & 0.644 & 0.660 & 0.670 \\
\hline & L-20A (R-444B) & 0.525 & 0.576 & 0.626 & 0.624 & 0.643 & 0.654 \\
\hline & DR-3 & 0.559 & 0.591 & 0.623 & 0.625 & 0.641 & 0.653 \\
\hline & N-20B & 0.515 & 0.548 & 0.571 & 0.573 & 0.592 & 0.604 \\
\hline & ARM-20B & 0.615 & 0.653 & 0.688 & 0.686 & 0.706 & 0.715 \\
\hline & R-290/POE & 0.587 & 0.610 & 0.630 & 0.634 & 0.649 & 0.659 \\
\hline & R-290/mineral oil & 0.591 & 0.613 & 0.631 & 0.634 & 0.653 & 0.668 \\
\hline & DR-93 & 0.585 & 0.617 & 0.649 & 0.651 & 0.672 & 0.686 \\
\hline \multirow{10}{*}{$\begin{array}{l}\text { Compressor } \\
\text { Suction } \\
\text { Temperature, } \\
{ }^{\circ} \mathrm{C}\end{array}$} & R-22/mineral oil & 13.79 & 12.55 & 9.50 & 9.53 & 9.59 & 9.80 \\
\hline & $\mathrm{R}-22 /$ mineral oil rerun & 14.68 & 13.75 & 10.40 & 10.63 & 11.71 & 11.97 \\
\hline & R-22/POE & 15.10 & 14.70 & 10.63 & 11.14 & 10.02 & 10.37 \\
\hline & L-20A (R-444B) & 15.51 & 16.13 & 12.13 & 12.01 & 11.77 & 12.16 \\
\hline & DR-3 & 14.31 & 14.90 & 13.04 & 13.15 & 11.85 & 11.83 \\
\hline & N-20B & 14.78 & 14.72 & 11.85 & 12.19 & 12.02 & 12.45 \\
\hline & ARM-20B & 14.14 & 14.59 & 13.22 & 12.90 & 12.51 & 12.22 \\
\hline & R-290/POE & 14.71 & 15.16 & 15.51 & 16.29 & 16.85 & 17.74 \\
\hline & R-290/mineral oil & 14.68 & 15.20 & 15.85 & 16.16 & 16.69 & 16.79 \\
\hline & DR-93 & 13.90 & 14.15 & 12.42 & 12.59 & 11.25 & 11.03 \\
\hline
\end{tabular}


Table D.1. (continued)

\begin{tabular}{|c|c|c|c|c|c|c|c|}
\hline & \multirow{2}{*}{ Refrigerant } & \multicolumn{6}{|c|}{ Test conditions } \\
\hline & & $\mathrm{B}$ & A & $\mathrm{T} 3 *$ & T3 & Hot & Extreme \\
\hline \multirow{10}{*}{$\begin{array}{c}\text { Saturation } \\
\text { Temperature, } \\
\text { Liquid Line, } \\
{ }^{\circ} \mathrm{C}\end{array}$} & R-22/mineral oil & 38.0 & 45.1 & 54.0 & 54.1 & 59.5 & 62.2 \\
\hline & $\mathrm{R}-22 /$ mineral oil rerun & 38.1 & 45.4 & 54.2 & 54.2 & 59.7 & 62.4 \\
\hline & $\mathrm{R}-22 / \mathrm{POE}$ & 40.1 & 47.5 & 56.2 & 56.4 & 62.1 & 64.9 \\
\hline & L-20A (R-444B) & 36.9 & 44.1 & 54.5 & 54.2 & 60.0 & 63.0 \\
\hline & DR-3 & 39.8 & 46.5 & 56.4 & 56.2 & 61.9 & 65.2 \\
\hline & $\mathrm{N}-20 \mathrm{~B}$ & 38.5 & 45.8 & 54.8 & 54.8 & 60.6 & 63.5 \\
\hline & ARM-20B & 37.5 & 43.8 & 53.9 & 53.9 & 59.5 & 62.4 \\
\hline & $\mathrm{R}-290 / \mathrm{POE}$ & 38.4 & 45.4 & 55.3 & 55.4 & 60.1 & 62.8 \\
\hline & R-290/mineral oil & 37.4 & 44.4 & 54.4 & 54.4 & 59.1 & 61.6 \\
\hline & DR-93 & 38.8 & 45.2 & 55.1 & 55.0 & 60.8 & 63.7 \\
\hline \multirow{10}{*}{$\begin{array}{l}\text { Saturation } \\
\text { Temperature, } \\
\text { Evaporator } \\
\text { Inlet, }{ }^{\circ} \mathrm{C}\end{array}$} & R-22/mineral oil & 10.23 & 12.15 & 14.30 & 14.52 & 15.82 & 16.44 \\
\hline & $\mathrm{R}-22 /$ mineral oil rerun & 10.03 & 12.24 & 14.40 & 14.53 & 15.89 & 16.52 \\
\hline & $\mathrm{R}-22 / \mathrm{POE}$ & 9.02 & 11.57 & 13.75 & 14.01 & 15.23 & 15.88 \\
\hline & L-20A (R-444B) & 10.42 & 13.42 & 16.70 & 16.57 & 17.91 & 18.59 \\
\hline & DR-3 & 12.76 & 14.95 & 17.40 & 17.48 & 18.86 & 19.74 \\
\hline & $\mathrm{N}-20 \mathrm{~B}$ & 12.48 & 14.84 & 17.19 & 17.31 & 18.86 & 19.71 \\
\hline & ARM-20B & 10.77 & 12.93 & 15.10 & 15.05 & 16.40 & 17.04 \\
\hline & R-290/POE & 10.37 & 12.04 & 13.79 & 14.02 & 15.13 & 15.80 \\
\hline & R-290/mineral oil & 10.63 & 12.37 & 14.04 & 14.20 & 15.60 & 16.49 \\
\hline & DR-93 & 11.86 & 13.93 & 16.29 & 16.41 & 17.85 & 18.72 \\
\hline \multirow{10}{*}{$\begin{array}{l}\text { Saturation } \\
\text { Temperature, } \\
\text { Evaporator } \\
\text { Outlet, }{ }^{\circ} \mathrm{C}\end{array}$} & $\mathrm{R}-22 /$ mineral oil & 5.09 & 6.59 & 7.78 & 8.02 & 8.82 & 9.22 \\
\hline & $\mathrm{R}-22 /$ mineral oil rerun & 5.14 & 6.97 & 8.12 & 8.26 & 9.15 & 9.55 \\
\hline & $\mathrm{R}-22 / \mathrm{POE}$ & 4.29 & 6.60 & 7.86 & 8.14 & 8.97 & 9.44 \\
\hline & L-20A (R-444B) & 6.14 & 8.90 & 11.47 & 11.38 & 12.32 & 12.84 \\
\hline & DR-3 & 6.69 & 8.46 & 10.15 & 10.26 & 11.08 & 11.68 \\
\hline & $\mathrm{N}-20 \mathrm{~B}$ & 6.38 & 8.29 & 9.61 & 9.71 & 10.76 & 11.41 \\
\hline & ARM-20B & 5.76 & 7.65 & 9.30 & 9.22 & 10.16 & 10.57 \\
\hline & R-290/POE & 7.19 & 8.49 & 9.62 & 9.85 & 10.69 & 11.23 \\
\hline & R-290/mineral oil & 7.38 & 8.68 & 9.69 & 9.85 & 10.92 & 11.70 \\
\hline & DR-93 & 6.06 & 7.66 & 9.25 & 9.37 & 10.39 & 11.02 \\
\hline
\end{tabular}


Table D.1. (continued)

\begin{tabular}{|c|c|c|c|c|c|c|c|}
\hline & \multirow{2}{*}{ Refrigerant } & \multicolumn{6}{|c|}{ Test conditions } \\
\hline & & $\mathrm{B}$ & A & T3* & T3 & Hot & Extreme \\
\hline \multirow{10}{*}{$\begin{array}{c}\text { Saturation } \\
\text { Temperature, } \\
\text { Compressor } \\
\text { Discharge, }{ }^{\circ} \mathrm{C}\end{array}$} & R-22/mineral oil & 38.0 & 45.1 & 54.0 & 54.1 & 59.5 & 62.2 \\
\hline & $\mathrm{R}-22 /$ mineral oil rerun & 38.1 & 45.4 & 54.2 & 54.2 & 59.7 & 62.4 \\
\hline & $\mathrm{R}-22 / \mathrm{POE}$ & 40.1 & 47.5 & 56.2 & 56.4 & 62.1 & 64.9 \\
\hline & L-20A (R-444B) & 44.6 & 51.4 & 61.2 & 60.9 & 66.3 & 69.0 \\
\hline & DR-3 & 46.3 & 52.6 & 61.8 & 61.6 & 66.8 & 69.7 \\
\hline & $\mathrm{N}-20 \mathrm{~B}$ & 43.2 & 50.2 & 58.8 & 58.8 & 64.3 & 67.1 \\
\hline & ARM-20B & 42.9 & 48.9 & 58.6 & 58.5 & 63.9 & 66.5 \\
\hline & $\mathrm{R}-290 / \mathrm{POE}$ & 38.4 & 45.4 & 55.3 & 55.4 & 60.1 & 62.8 \\
\hline & R-290/mineral oil & 37.4 & 44.4 & 54.4 & 54.4 & 59.1 & 61.6 \\
\hline & DR-93 & 43.7 & 49.8 & 59.2 & 59.2 & 64.6 & 67.3 \\
\hline \multirow{10}{*}{$\begin{array}{l}\text { Mass Flow } \\
\text { Rate, kg/min }\end{array}$} & R-22/mineral oil & 2.20 & 2.32 & 2.42 & 2.44 & 2.47 & 2.48 \\
\hline & $\mathrm{R}-22 /$ mineral oil rerun & 2.16 & 2.29 & 2.38 & 2.39 & 2.43 & 2.44 \\
\hline & $\mathrm{R}-22 / \mathrm{POE}$ & 2.09 & 2.24 & 2.34 & 2.35 & 2.39 & 2.41 \\
\hline & L-20A (R-444B) & 1.57 & 1.70 & 1.86 & 1.85 & 1.90 & 1.92 \\
\hline & DR-3 & 2.17 & 2.28 & 2.40 & 2.41 & 2.47 & 2.50 \\
\hline & $\mathrm{N}-20 \mathrm{~B}$ & 2.13 & 2.26 & 2.36 & 2.36 & 2.43 & 2.46 \\
\hline & ARM-20B & 2.00 & 2.11 & 2.20 & 2.20 & 2.25 & 2.26 \\
\hline & R-290/POE & 1.17 & 1.20 & 1.22 & 1.23 & 1.24 & 1.25 \\
\hline & R-290/mineral oil & 1.17 & 1.21 & 1.25 & 1.24 & 1.33 & 1.30 \\
\hline & DR-93 & 2.22 & 2.33 & 2.44 & 2.44 & 2.50 & 2.53 \\
\hline \multirow{10}{*}{$\begin{array}{l}\text { Temperature } \\
\text { Glide at the } \\
\text { Evaporator, } \\
{ }^{\circ} \mathrm{C}\end{array}$} & R-22/mineral oil & -5.14 & -5.56 & -6.52 & -6.50 & -7.00 & -7.23 \\
\hline & $\mathrm{R}-22 /$ mineral oil rerun & -4.89 & -5.27 & -6.28 & -6.27 & -6.75 & -6.97 \\
\hline & $\mathrm{R}-22 / \mathrm{POE}$ & -4.73 & -4.98 & -5.89 & -5.87 & -6.26 & -6.44 \\
\hline & L-20A (R-444B) & 4.38 & 3.82 & 2.52 & 2.58 & 1.82 & 1.46 \\
\hline & DR-3 & -0.23 & -1.07 & -2.57 & -2.51 & -3.48 & -3.99 \\
\hline & $\mathrm{N}-20 \mathrm{~B}$ & -1.71 & -2.48 & -4.08 & -4.09 & -4.88 & -5.23 \\
\hline & ARM-20B & -0.10 & -0.70 & -1.81 & -1.83 & -2.60 & -3.02 \\
\hline & R-290/POE & -3.19 & -3.55 & -4.16 & -4.17 & -4.44 & -4.57 \\
\hline & R-290/mineral oil & -3.25 & -3.69 & -4.35 & -4.35 & - & - \\
\hline & DR-93 & -1.77 & -0.99 & -3.05 & -3.04 & -3.77 & -4.16 \\
\hline
\end{tabular}


Table D.1. (continued)

\begin{tabular}{|c|c|c|c|c|c|c|c|}
\hline & \multirow{2}{*}{ Refrigerant } & \multicolumn{6}{|c|}{ Test conditions } \\
\hline & & B & A & T3* & T3 & Hot & Extreme \\
\hline \multirow{10}{*}{$\begin{array}{l}\text { Energy } \\
\text { Balance }\end{array}$} & R-22/mineral oil & $1.33 \%$ & $1.50 \%$ & - & - & - & - \\
\hline & $\mathrm{R}-22 /$ mineral oil rerun & $2.37 \%$ & $2.89 \%$ & $7.57 \%$ & $7.72 \%$ & $10.46 \%$ & - \\
\hline & $\mathrm{R}-22 / \mathrm{POE}$ & $1.87 \%$ & $2.12 \%$ & $7.89 \%$ & $7.97 \%$ & $11.18 \%$ & $13.15 \%$ \\
\hline & L-20A (R-444B) & $-1.99 \%$ & $-1.38 \%$ & - & - & - & - \\
\hline & DR-3 & $-1.14 \%$ & $-2.30 \%$ & - & - & - & - \\
\hline & $\mathrm{N}-20 \mathrm{~B}$ & $0.12 \%$ & $0.68 \%$ & - & - & - & - \\
\hline & ARM-20B & $1.55 \%$ & $1.52 \%$ & - & - & - & - \\
\hline & R-290/POE & $0.97 \%$ & $1.39 \%$ & $2.43 \%$ & $3.08 \%$ & $3.72 \%$ & $4.11 \%$ \\
\hline & R-290/mineral oil & $1.39 \%$ & $1.53 \%$ & - & - & - & - \\
\hline & DR-93 & $0.04 \%$ & $-0.34 \%$ & - & - & - & - \\
\hline \multirow{10}{*}{$\begin{array}{c}\text { Capillary } \\
\text { Tube Length, } \\
\text { mm }\end{array}$} & R-22/mineral oil & \multicolumn{6}{|c|}{ Original } \\
\hline & R-22/mineral oil rerun & \multicolumn{6}{|c|}{ Original } \\
\hline & $\mathrm{R}-22 / \mathrm{POE}$ & \multicolumn{6}{|c|}{254} \\
\hline & L-20A (R-444B) & \multicolumn{6}{|c|}{356} \\
\hline & DR-3 & \multicolumn{6}{|c|}{178} \\
\hline & $\mathrm{N}-20 \mathrm{~B}$ & \multicolumn{6}{|c|}{152} \\
\hline & ARM-20B & \multicolumn{6}{|c|}{178} \\
\hline & R-290/POE & \multicolumn{6}{|c|}{203} \\
\hline & R-290/mineral oil & \multicolumn{6}{|c|}{ Original } \\
\hline & DR-93 & \multicolumn{6}{|c|}{152} \\
\hline \multirow{10}{*}{$\begin{array}{l}\text { Refrigerant } \\
\text { Charge, kg }\end{array}$} & R-22/mineral oil & \multicolumn{6}{|c|}{1.417} \\
\hline & $\mathrm{R}-22 /$ mineral oil rerun & \multicolumn{6}{|c|}{1.545} \\
\hline & R-22/POE & \multicolumn{6}{|c|}{1.984} \\
\hline & L-20A (R-444B) & \multicolumn{6}{|c|}{1.568} \\
\hline & DR-3 & \multicolumn{6}{|c|}{2.007} \\
\hline & $\mathrm{N}-20 \mathrm{~B}$ & \multicolumn{6}{|c|}{2.087} \\
\hline & ARM-20B & \multicolumn{6}{|c|}{1.588} \\
\hline & R-290/POE & \multicolumn{6}{|c|}{0.731} \\
\hline & R-290/mineral oil & \multicolumn{6}{|c|}{0.714} \\
\hline & DR-93 & \multicolumn{6}{|c|}{1.829} \\
\hline
\end{tabular}


Table D.2. Additional test data for the $\mathbf{R}-22$ unit using the original capillary tube

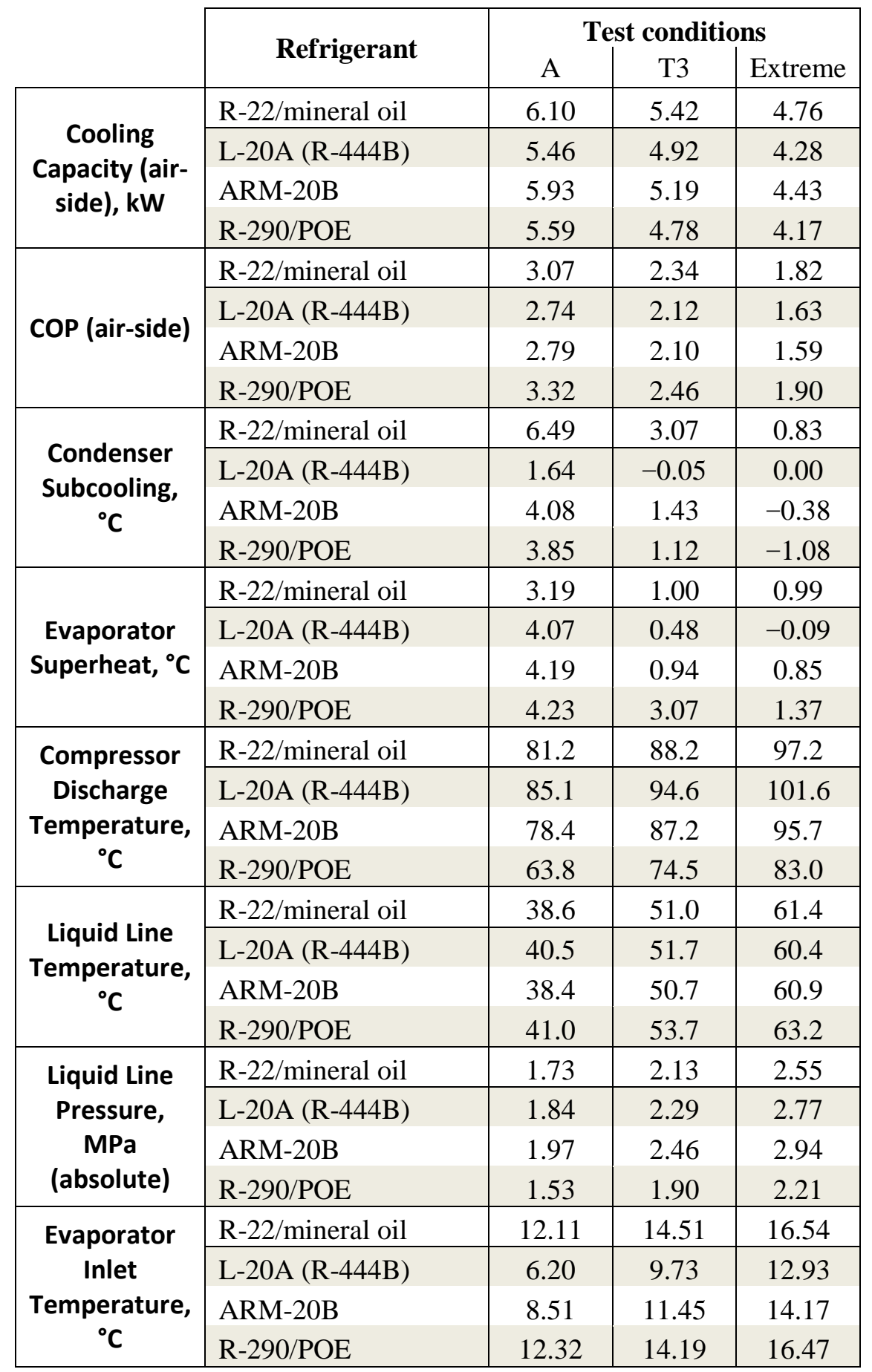


Table D.2. (continued)

\begin{tabular}{|c|c|c|c|c|}
\hline & \multirow{2}{*}{ Refrigerant } & \multicolumn{3}{|c|}{ Test conditions } \\
\hline & & A & T3 & Extreme \\
\hline \multirow{4}{*}{$\begin{array}{c}\text { Evaporator } \\
\text { Inlet } \\
\text { Pressure, } \\
\text { MPa } \\
\text { (absolute) }\end{array}$} & R-22/mineral oil & 0.726 & 0.778 & 0.823 \\
\hline & L-20A (R-444B) & 0.682 & 0.744 & 0.802 \\
\hline & ARM-20B & 0.778 & 0.836 & 0.890 \\
\hline & $\mathrm{R}-290 / \mathrm{POE}$ & 0.684 & 0.719 & 0.764 \\
\hline \multirow{4}{*}{$\begin{array}{c}\text { Evaporator } \\
\text { Outlet } \\
\text { Temperature, } \\
{ }^{\circ} \mathrm{C}\end{array}$} & R-22/mineral oil & 9.78 & 9.02 & 10.21 \\
\hline & L-20A (R-444B) & 13.37 & 11.83 & 12.87 \\
\hline & ARM-20B & 12.11 & 10.41 & 11.67 \\
\hline & R-290/POE & 13.10 & 13.13 & 13.17 \\
\hline \multirow{4}{*}{$\begin{array}{c}\text { Evaporator } \\
\text { Outlet } \\
\text { Pressure, } \\
\text { MPa } \\
\text { (absolute) }\end{array}$} & R-22/mineral oil & 0.61 & 0.64 & 0.67 \\
\hline & L-20A (R-444B) & 0.58 & 0.62 & 0.66 \\
\hline & ARM-20B & 0.66 & 0.69 & 0.72 \\
\hline & R-290/POE & 0.62 & 0.64 & 0.67 \\
\hline \multirow{4}{*}{$\begin{array}{l}\text { Compressor } \\
\text { Suction } \\
\text { Temperature, } \\
{ }^{\circ} \mathrm{C} \\
\end{array}$} & R-22/mineral oil & 12.55 & 9.53 & 9.80 \\
\hline & L-20A (R-444B) & 16.92 & 14.82 & 13.02 \\
\hline & ARM-20B & 15.12 & 13.34 & 11.44 \\
\hline & $\mathrm{R}-290 / \mathrm{POE}$ & 16.12 & 17.27 & 17.85 \\
\hline \multirow{4}{*}{$\begin{array}{c}\text { Saturation } \\
\text { Temperature, } \\
\text { Liquid Line, } \\
{ }^{\circ} \mathrm{C}\end{array}$} & R-22/mineral oil & 45.1 & 54.1 & 62.2 \\
\hline & L-20A (R-444B) & 42.1 & 51.7 & 60.4 \\
\hline & ARM-20B & 42.5 & 52.2 & 60.5 \\
\hline & R-290/POE & 44.8 & 54.8 & 62.1 \\
\hline \multirow{4}{*}{$\begin{array}{c}\text { Saturation } \\
\text { Temperature, } \\
\text { Evaporator } \\
\text { Inlet, }{ }^{\circ} \mathrm{C} \\
\end{array}$} & R-22/mineral oil & 12.2 & 14.5 & 16.4 \\
\hline & L-20A (R-444B) & 14.2 & 17.0 & 19.4 \\
\hline & ARM-20B & 13.3 & 15.7 & 17.8 \\
\hline & $\mathrm{R}-290 / \mathrm{POE}$ & 12.6 & 14.4 & 16.6 \\
\hline \multirow{4}{*}{$\begin{array}{c}\text { Saturation } \\
\text { Temperature, } \\
\text { Evaporator } \\
\text { Outlet, }{ }^{\circ} \mathrm{C}\end{array}$} & R-22/mineral oil & 6.59 & 8.02 & 9.22 \\
\hline & L-20A (R-444B) & 9.30 & 11.35 & 12.96 \\
\hline & ARM-20B & 7.92 & 9.46 & 10.82 \\
\hline & R-290/POE & 8.87 & 10.06 & 11.80 \\
\hline \multirow{4}{*}{$\begin{array}{c}\text { Saturation } \\
\text { Temperature, } \\
\text { Compressor } \\
\text { Discharge, }{ }^{\circ} \mathrm{C}\end{array}$} & R-22/mineral oil & 45.1 & 54.1 & 62.2 \\
\hline & L-20A (R-444B) & 49.5 & 58.5 & 66.6 \\
\hline & ARM-20B & 47.7 & 56.9 & 64.8 \\
\hline & $\mathrm{R}-290 / \mathrm{POE}$ & 44.8 & 54.8 & 62.1 \\
\hline
\end{tabular}


Table D.2. (continued)

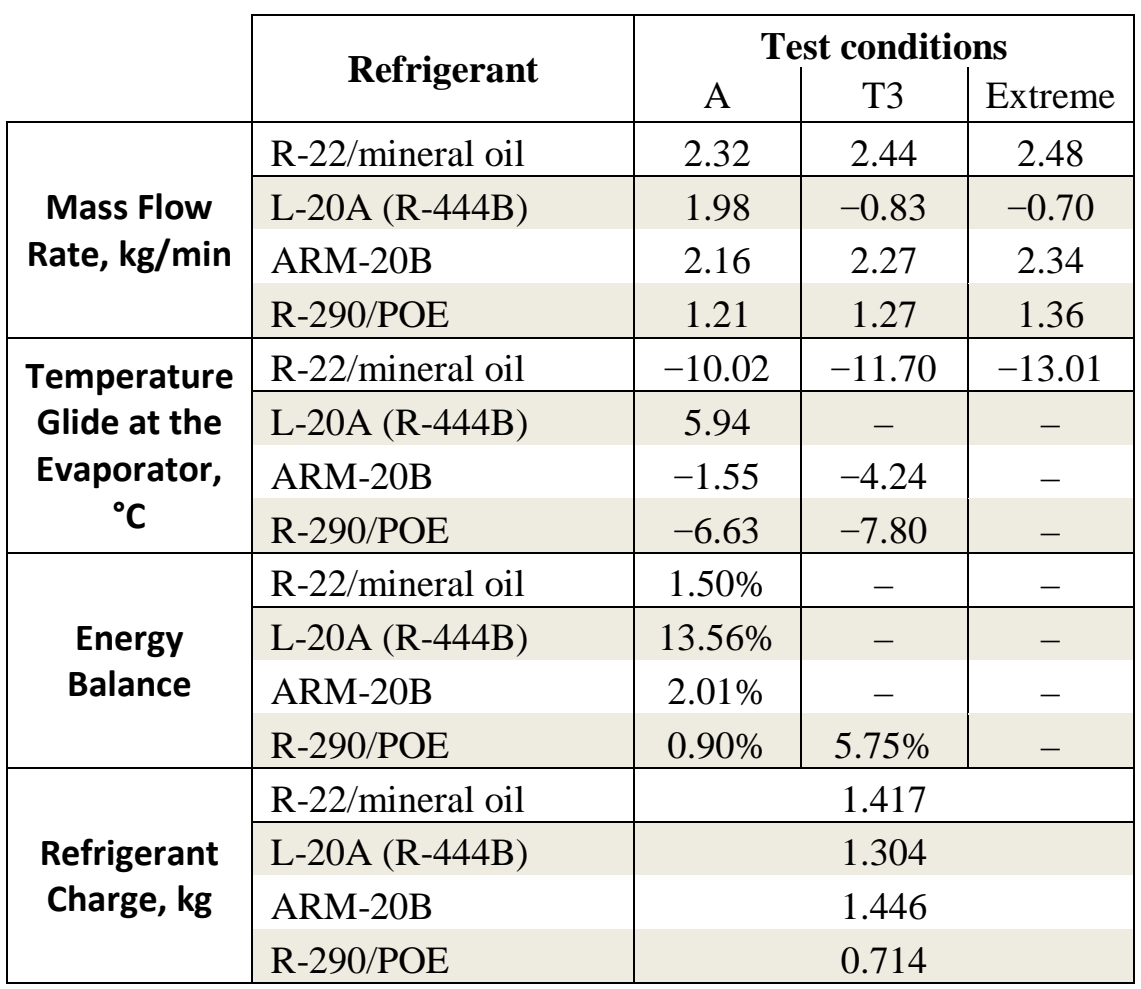



APPENDIX E. DETAILED R-410A TEST DATA 



\section{APPENDIX E. DETAILED R-410A TEST DATA}

This appendix provides additional details of the testing documented in Section 6.2.

Figure E.1 shows the COP for each refrigerant at each test condition. Note that ORNL conducted two sets of tests with R-410A: one set used as the baseline test result and one set of "rerun" tests conducted after the alternatives had been tested in the unit. By comparing the results before and after testing of the alternative refrigerants, it is possible to establish the performance reliability using the alternative refrigerants. The maximum discrepancy between the first R-410A run and the rerun was approximately $2.5 \%$ both for COP and cooling capacity; this result is within the experimental uncertainty.

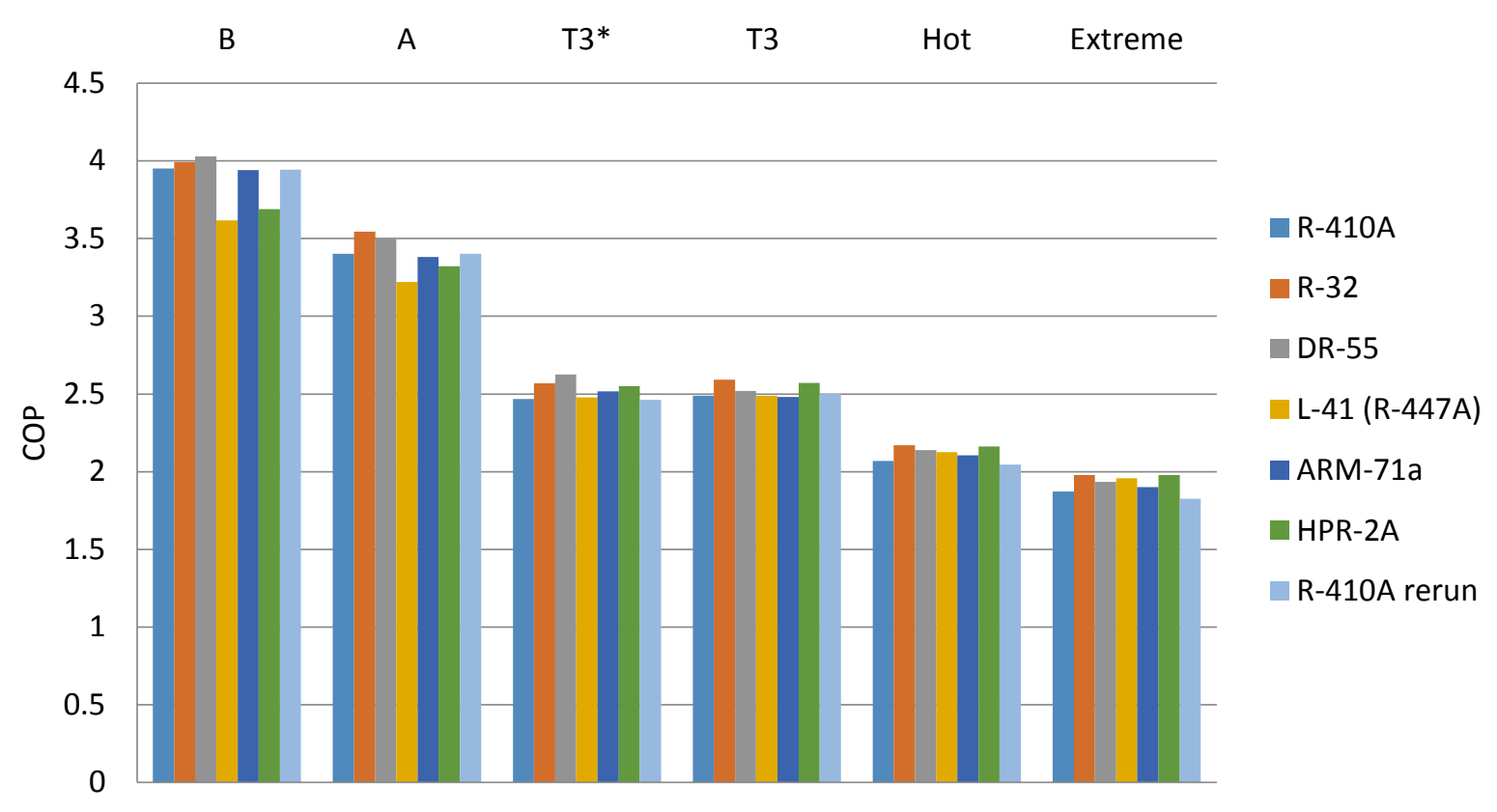

Figure E.1. COP for R-410A and its alternatives at each test condition, including the R-410A rerun.

Figure E.2 shows the cooling capacity for each refrigerant at each test condition, including the R-410A rerun. 


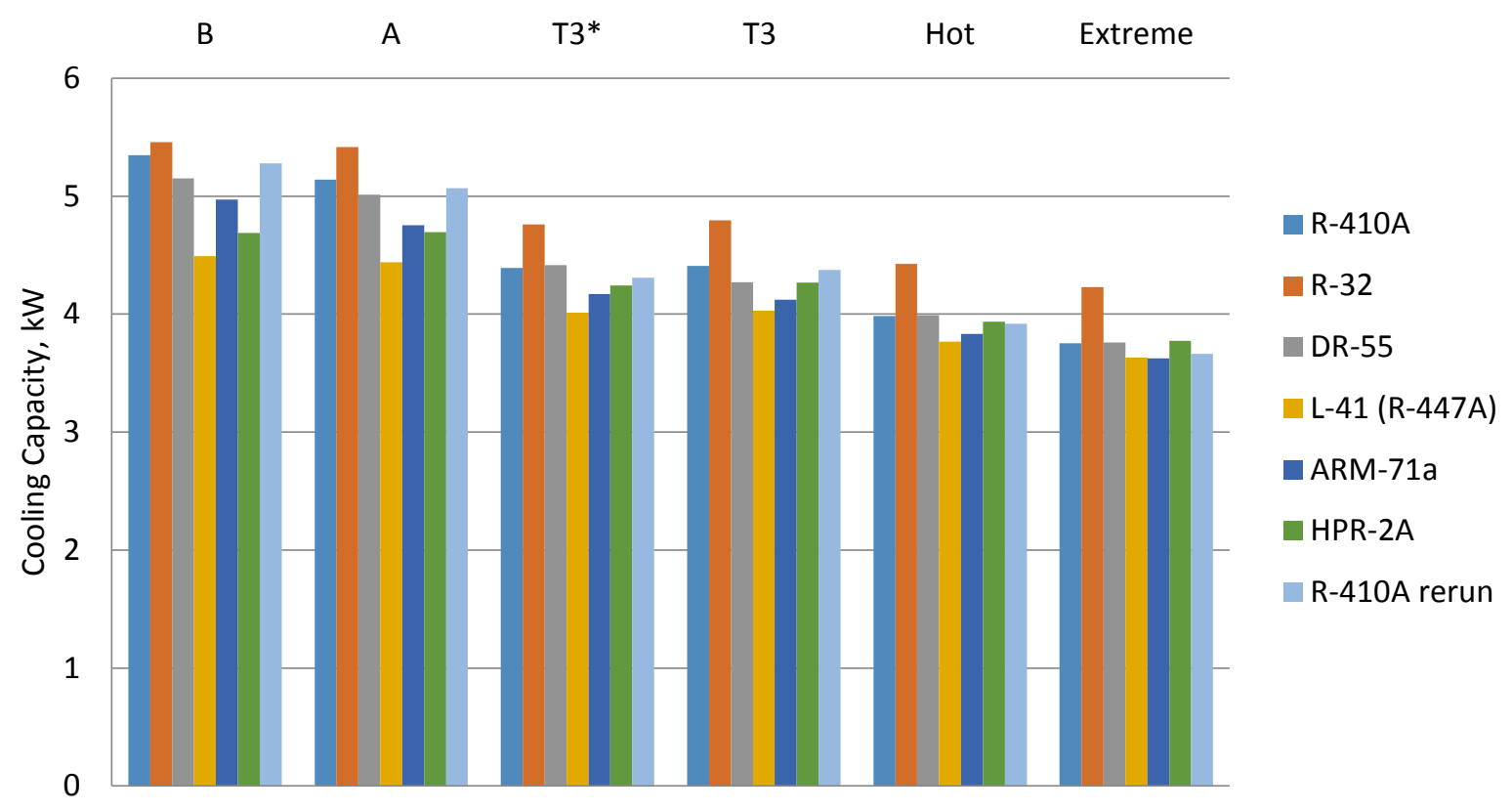

Figure E.2. Cooling capacity for $\mathrm{R}-410 \mathrm{~A}$ and its alternatives at each test condition, including the $\mathrm{R}-410 \mathrm{~A}$ rerun.

Figure E.3 shows the COP of each refrigerant at each test condition, relative to the COP of that refrigerant at AHRI A conditions.

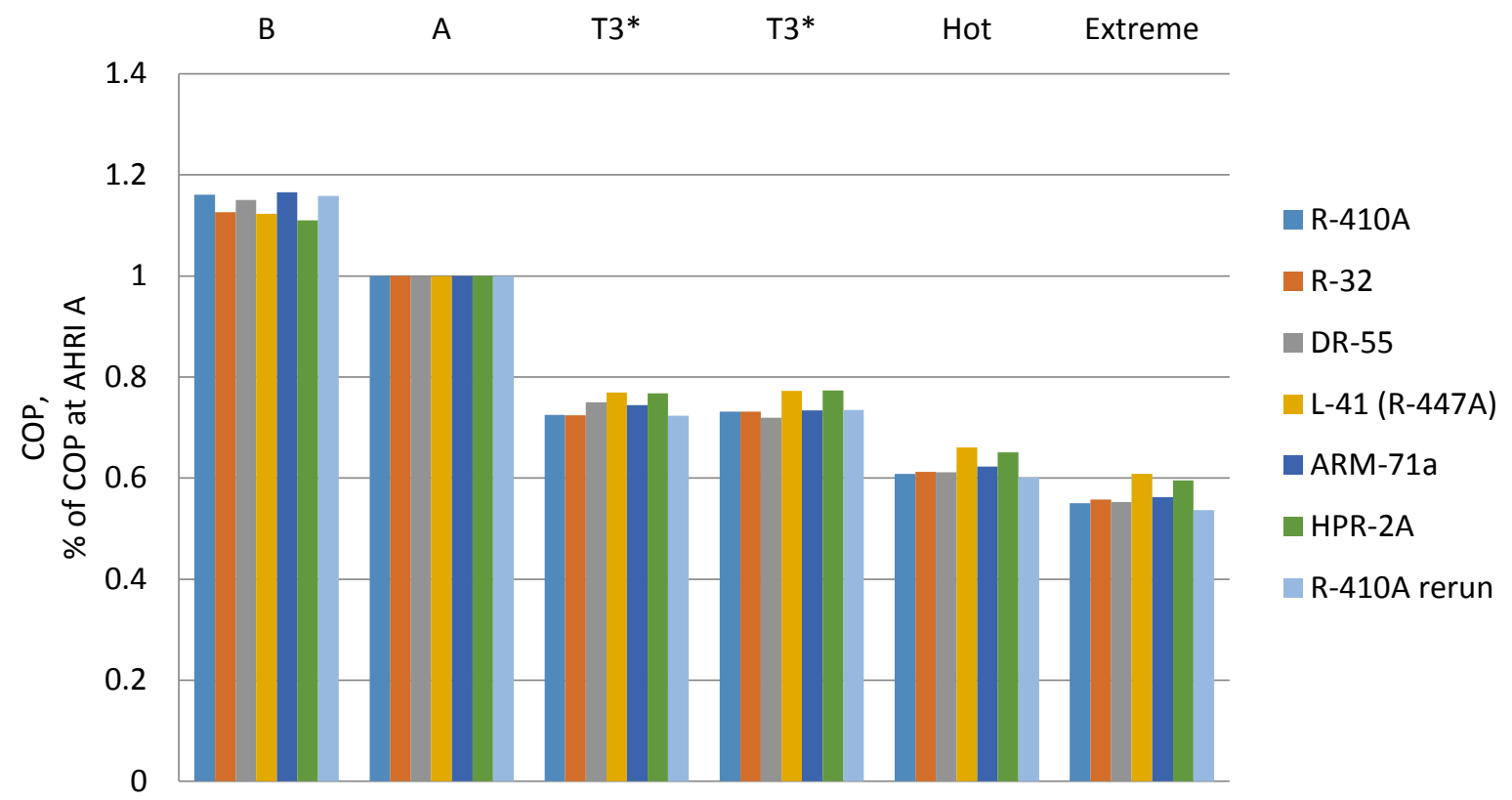

Figure E.3. COP for R-410A and its alternatives at each test condition, relative to the COP of that refrigerant at AHRI A conditions.

Figure E.4 shows the cooling capacity of each refrigerant at each test condition, relative to the cooling capacity of that refrigerant at AHRI A conditions. 


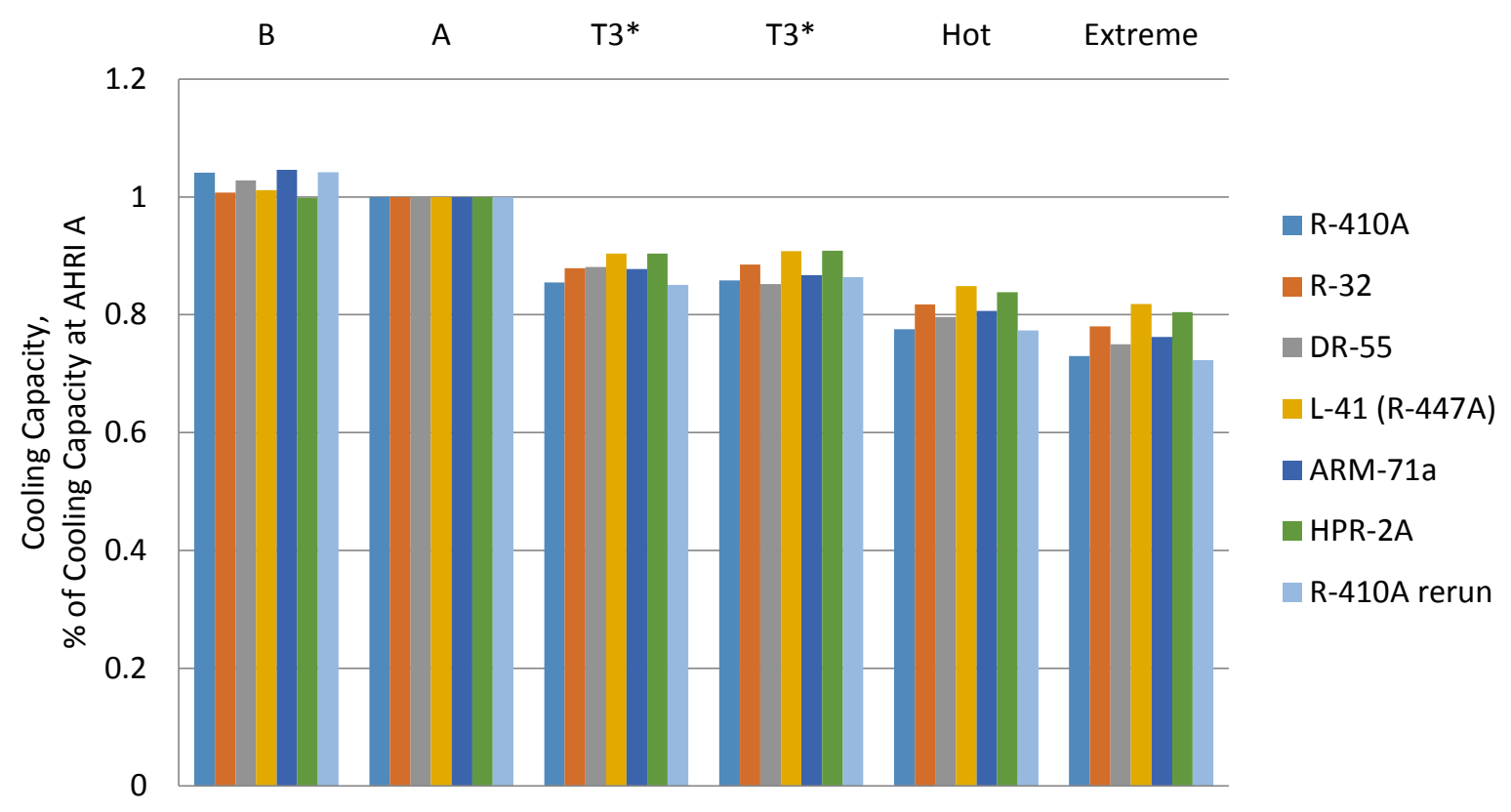

Figure E.4. Cooling capacity for R-410A and its alternatives at each test condition, relative to the cooling capacity of that refrigerant at AHRI A conditions.

Figure E.5 shows the condenser subcooling for each refrigerant under each of the test conditions.

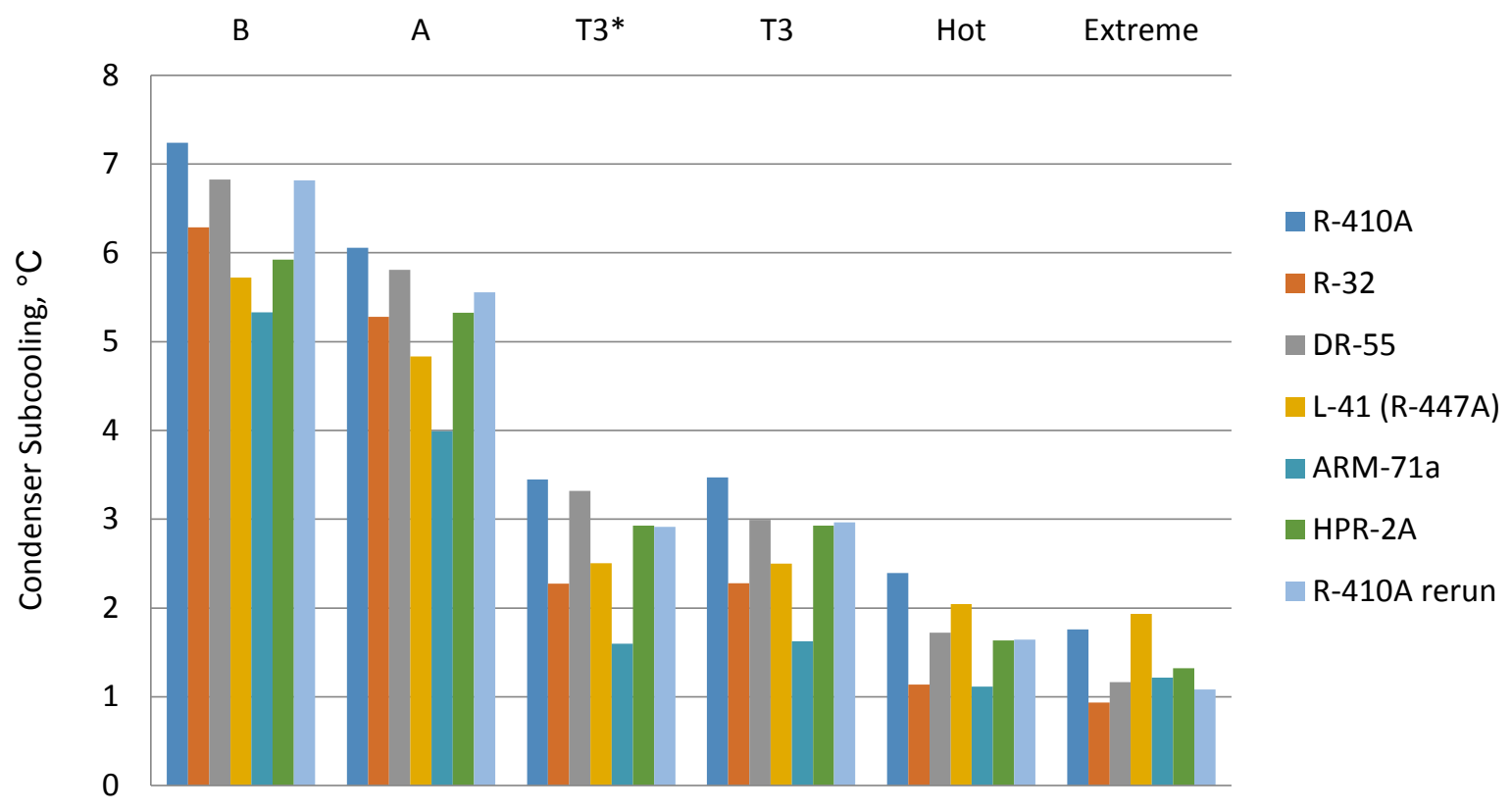

Figure E.5. Condenser subcooling for R-410A and its alternatives at each test condition.

Figure E.6 shows the evaporator superheat for each refrigerant under each of the test conditions. 


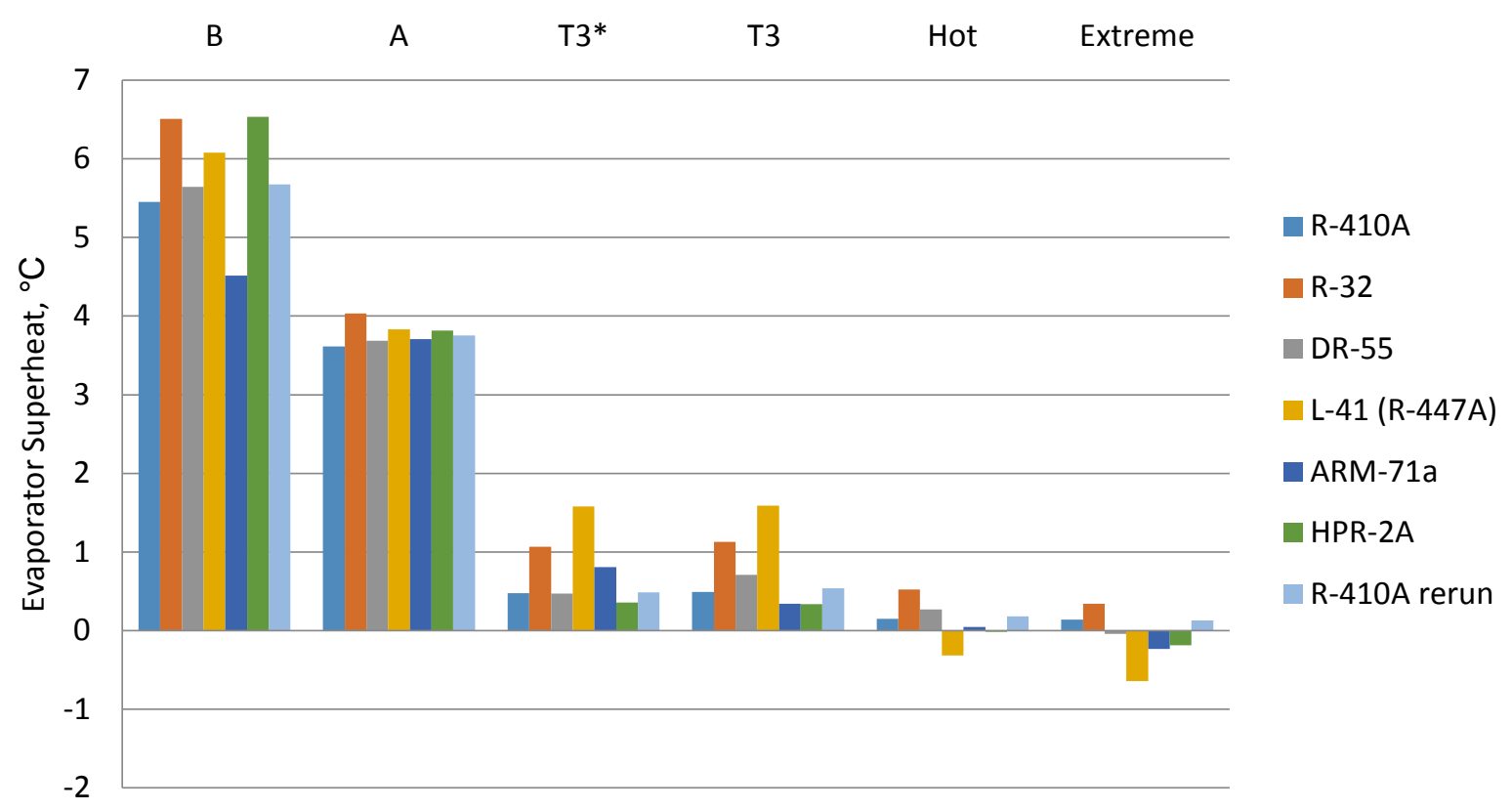

Figure E.6. Evaporator superheat for R-410A and its alternatives at each test condition.

Figure E.7 shows the compressor discharge temperature for each refrigerant under each of the test conditions.

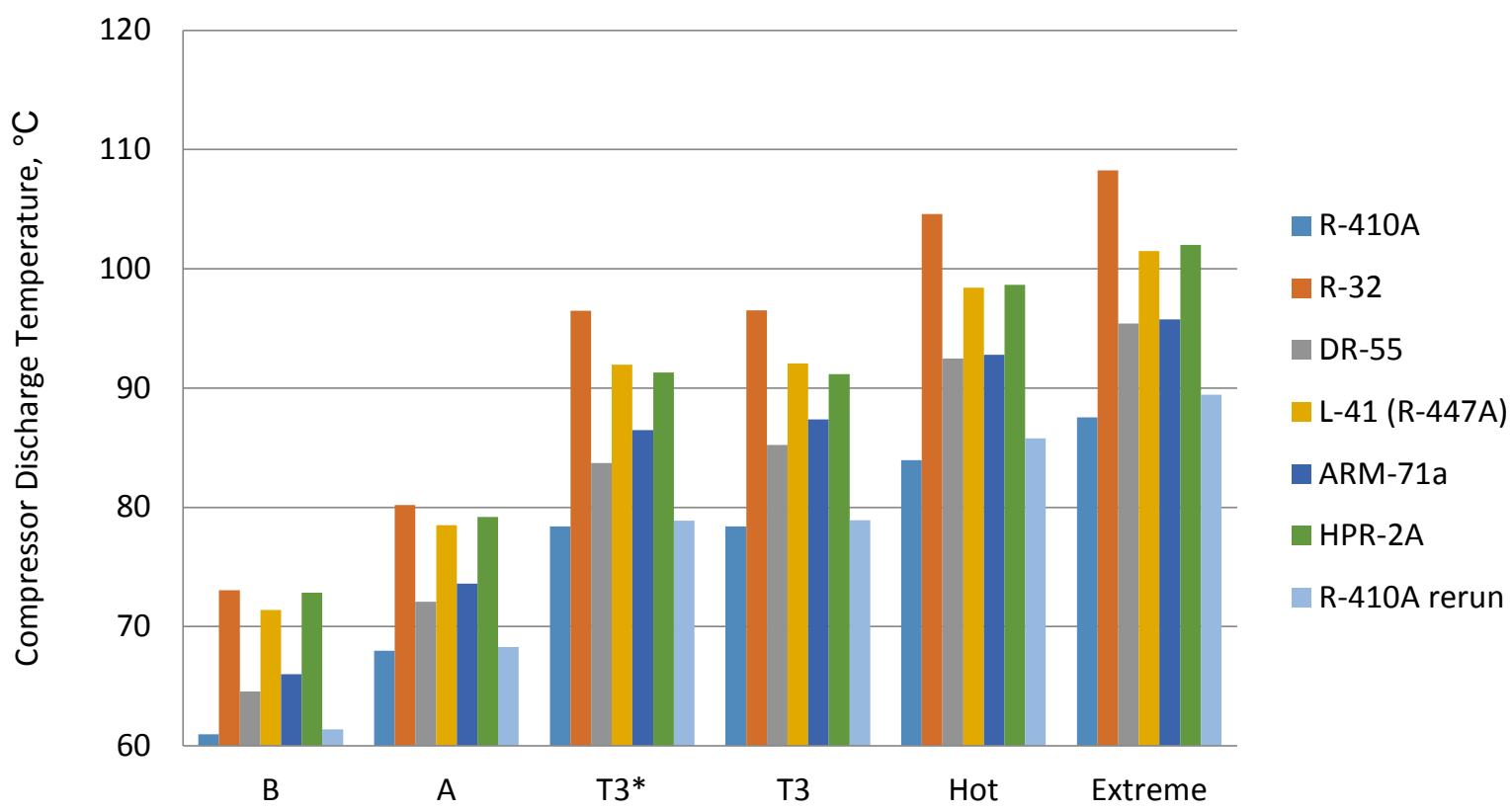

Figure E.7. Compressor discharge temperature for R-410A and its alternatives at each test condition.

Figure E.8 shows the temperature glide at the evaporator for each refrigerant under each of the test conditions. 


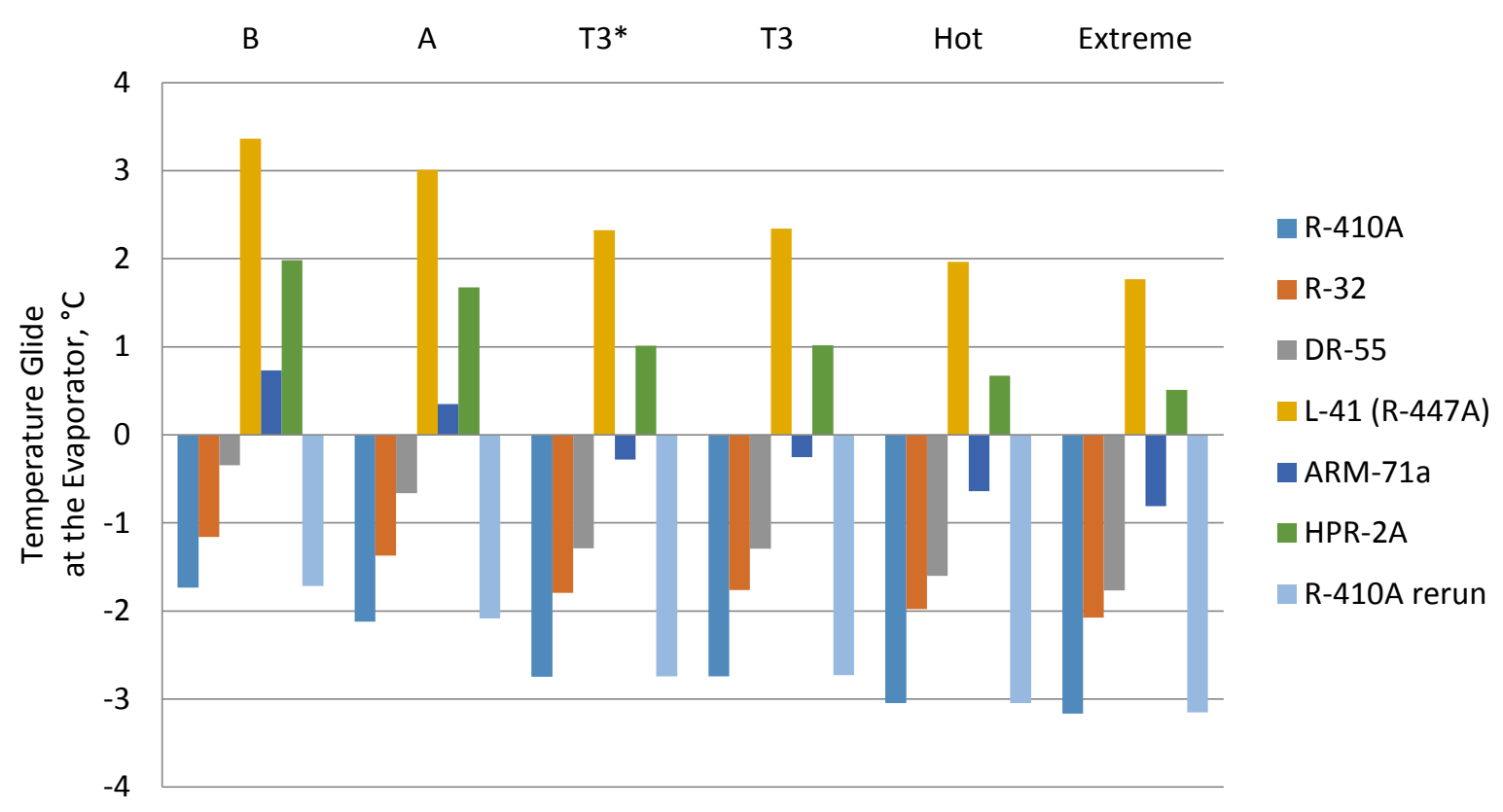

Figure E.8. Temperature glide at the evaporator for R-410A and its alternatives at each test condition.

Figure E.9 compares the COP and capacity of the alternative refrigerants to that of R-410A under the AHRI A test conditions, with all the refrigerants using the original capillary tube from the R-410A unit. These tests were done in addition to the tests described in Section 6.2.

Performance Relative to Baseline at AHRI A Conditions $35^{\circ} \mathrm{C}\left[95^{\circ} \mathrm{F}\right]$ Outdoor and $27^{\circ} \mathrm{C}\left[80^{\circ} \mathrm{F}\right]$ Indoor

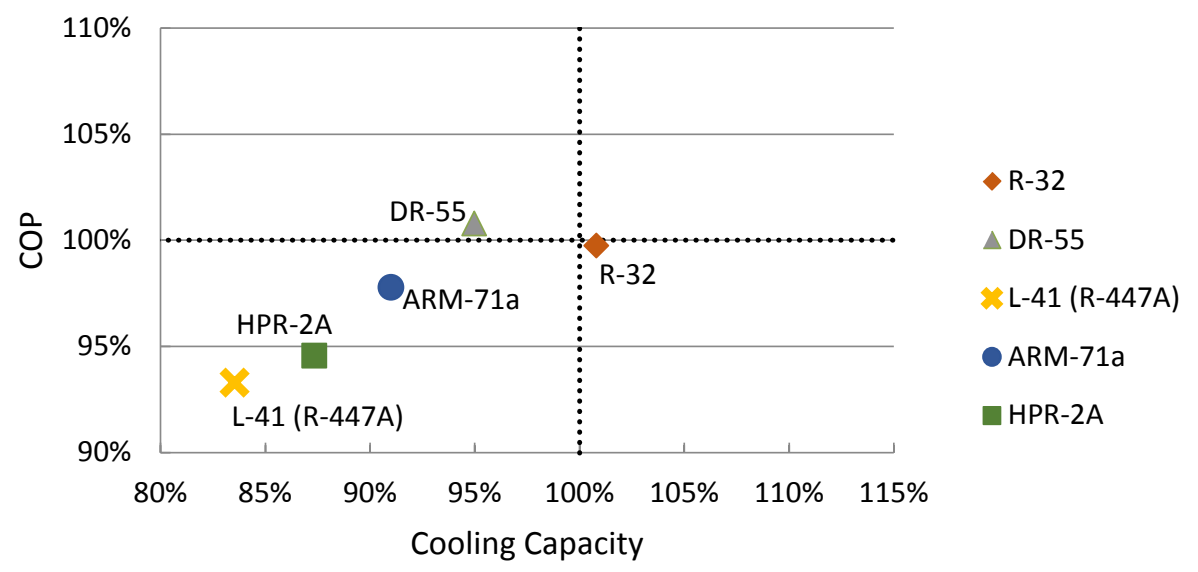

Figure E.9. Performance of alternative refrigerants compared with R-410A at AHRI A test conditions (outdoor temperature $35^{\circ} \mathrm{C}$ and indoor temperature $27^{\circ} \mathrm{C}$ ), all using the original capillary tube from the R-410A unit.

Figure E.10 compares the COP and capacity of the alternative refrigerants to that of R-410A under the ISO T3 test conditions, with all the refrigerants using the original capillary tube from the R-410A unit. 
Performance Relative to Baseline at ISO T3 Conditions $46^{\circ} \mathrm{C}\left[114.8^{\circ} \mathrm{F}\right]$ Outdoor and $29^{\circ} \mathrm{C}\left[84.2^{\circ} \mathrm{F}\right]$ Indoor

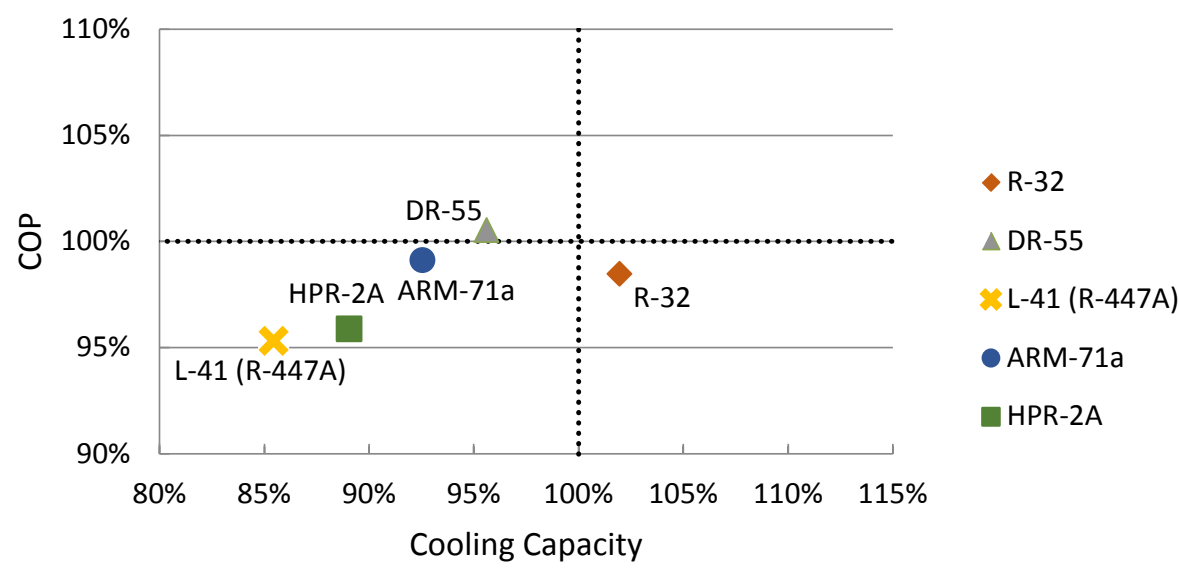

Figure E.10. Performance of alternative refrigerants compared with R-410A at ISO T3 (outdoor temperature $46^{\circ} \mathrm{C}$ and indoor temperature $29^{\circ} \mathrm{C}$ ), all using the original capillary tube from the R-410A unit.

Figure E.11 compares the COP and capacity of the alternative refrigerants to that of R-410A under Extreme test conditions, with all the refrigerants using the original capillary tube from the R-410A unit.

Performance Relative to Baseline at Extreme Conditions $55^{\circ} \mathrm{C}\left[131^{\circ} \mathrm{F}\right]$ Outdoor and $29^{\circ} \mathrm{C}\left[84.2^{\circ} \mathrm{F}\right]$ Indoor

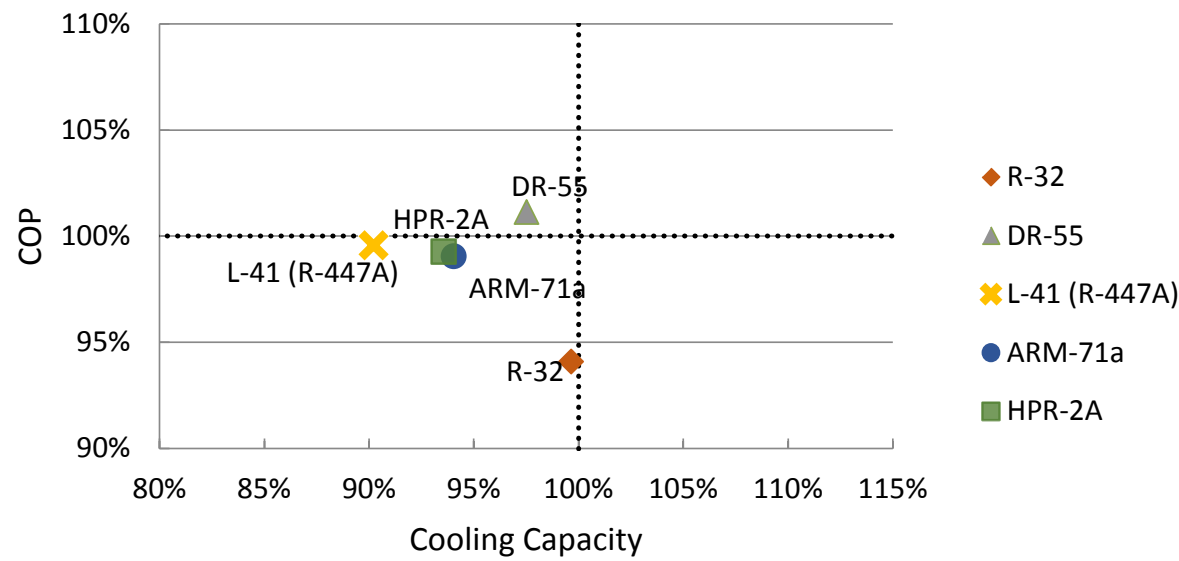

Figure E.11. Performance of alternative refrigerants compared with R-410A at Extreme test conditions (outdoor temperature $55^{\circ} \mathrm{C}$ and indoor temperature $29^{\circ} \mathrm{C}$ ), all using the original capillary tube from the R-410A unit.

Table E.1 shows additional test data, including

- $\quad$ air-side cooling capacity

- air-side COP

- liquid line temperature and pressure 
- evaporator inlet temperature and pressure

- evaporator outlet temperature and pressure

- compressor suction temperature

- saturation temperature at four different points within the cycle

- refrigerant mass flow rate

- capillary tube length

- refrigerant charge

Table E. 2 shows the additional test data for the test runs with the original capillary tube. 
Table E.1. Additional test data for the R-410A unit

\begin{tabular}{|c|c|c|c|c|c|c|c|}
\hline & \multirow{2}{*}{ Refrigerant } & \multicolumn{6}{|c|}{ Test conditions } \\
\hline & & B & A & T3* & $\mathrm{T} 3$ & Hot & Extreme \\
\hline \multirow{7}{*}{$\begin{array}{l}\text { Cooling } \\
\text { Capacity (air- } \\
\text { side), kW }\end{array}$} & $\mathrm{R}-410 \mathrm{~A}$ & 5.35 & 5.14 & 4.39 & 4.41 & 3.98 & 3.75 \\
\hline & $\mathrm{R}-32$ & 5.46 & 5.42 & 4.76 & 4.79 & 4.43 & 4.23 \\
\hline & DR-55 & 5.15 & 5.01 & 4.42 & 4.27 & 3.99 & 3.76 \\
\hline & L-41 (R-447A) & 4.49 & 4.44 & 4.01 & 4.03 & 3.77 & 3.63 \\
\hline & ARM-71a & 4.97 & 4.75 & 4.17 & 4.12 & 3.83 & 3.62 \\
\hline & HPR-2A & 4.69 & 4.69 & 4.24 & 4.27 & 3.93 & 3.77 \\
\hline & $\mathrm{R}-410 \mathrm{~A}$ rerun & 5.28 & 5.07 & 4.31 & 4.38 & 3.92 & 3.66 \\
\hline \multirow{7}{*}{$\begin{array}{c}\text { COP } \\
\text { (air-side) }\end{array}$} & $\mathrm{R}-410 \mathrm{~A}$ & 3.95 & 3.40 & 2.47 & 2.49 & 2.07 & 1.87 \\
\hline & $\mathrm{R}-32$ & 3.99 & 3.55 & 2.57 & 2.59 & 2.17 & 1.98 \\
\hline & DR-55 & 4.03 & 3.50 & 2.63 & 2.52 & 2.14 & 1.93 \\
\hline & L-41 (R-447A) & 3.62 & 3.22 & 2.48 & 2.49 & 2.13 & 1.96 \\
\hline & ARM-71a & 3.94 & 3.38 & 2.52 & 2.48 & 2.11 & 1.90 \\
\hline & HPR-2A & 3.69 & 3.32 & 2.55 & 2.57 & 2.16 & 1.98 \\
\hline & R-410A rerun & 3.94 & 3.40 & 2.46 & 2.50 & 2.05 & 1.83 \\
\hline \multirow{7}{*}{$\begin{array}{l}\text { Condenser } \\
\text { Subcooling, } \\
{ }^{\circ} \mathrm{C}\end{array}$} & $\mathrm{R}-410 \mathrm{~A}$ & 7.24 & 6.06 & 3.45 & 3.47 & 2.40 & 1.76 \\
\hline & $\mathrm{R}-32$ & 6.29 & 5.28 & 2.28 & 2.28 & 1.14 & 0.93 \\
\hline & DR-55 & 6.82 & 5.81 & 3.32 & 2.99 & 1.73 & 1.17 \\
\hline & L-41 (R-447A) & 5.72 & 4.83 & 2.50 & 2.50 & 2.04 & 1.93 \\
\hline & ARM-71a & 5.33 & 3.99 & 1.60 & 1.62 & 1.12 & 1.22 \\
\hline & HPR-2A & 5.92 & 5.33 & 2.93 & 2.93 & 1.64 & 1.32 \\
\hline & $\mathrm{R}-410 \mathrm{~A}$ rerun & 6.82 & 5.56 & 2.91 & 2.96 & 1.65 & 1.09 \\
\hline \multirow{7}{*}{$\begin{array}{l}\text { Evaporator } \\
\text { Superheat, } \\
{ }^{\circ} \mathrm{C}\end{array}$} & $\mathrm{R}-410 \mathrm{~A}$ & 5.45 & 3.61 & 0.48 & 0.49 & 0.15 & 0.14 \\
\hline & $\mathrm{R}-32$ & 6.51 & 4.03 & 1.07 & 1.13 & 0.52 & 0.34 \\
\hline & DR-55 & 5.64 & 3.68 & 0.47 & 0.71 & 0.27 & -0.04 \\
\hline & L-41 (R-447A) & 6.08 & 3.83 & 1.58 & 1.59 & -0.32 & -0.64 \\
\hline & ARM-71a & 4.52 & 3.71 & 0.81 & 0.34 & 0.05 & -0.23 \\
\hline & HPR-2A & 6.54 & 3.82 & 0.36 & 0.34 & -0.01 & -0.19 \\
\hline & $\mathrm{R}-410 \mathrm{~A}$ rerun & 5.67 & 3.75 & 0.49 & 0.54 & 0.18 & 0.13 \\
\hline
\end{tabular}


Table E.1. (continued)

\begin{tabular}{|c|c|c|c|c|c|c|c|}
\hline & \multirow{2}{*}{ Refrigerant } & \multicolumn{6}{|c|}{ Test conditions } \\
\hline & & B & A & T3* & T3 & Hot & Extreme \\
\hline \multirow{7}{*}{$\begin{array}{l}\text { Compressor } \\
\text { Discharge } \\
\text { Temperature, } \\
{ }^{\circ} \mathrm{C}\end{array}$} & $\mathrm{R}-410 \mathrm{~A}$ & 61.0 & 68.0 & 78.4 & 78.4 & 84.0 & 87.6 \\
\hline & $\mathrm{R}-32$ & 73.1 & 80.2 & 96.5 & 96.5 & 104.6 & 108.3 \\
\hline & DR-55 & 64.6 & 72.1 & 83.7 & 85.2 & 92.5 & 95.4 \\
\hline & L-41 (R-447A) & 71.4 & 78.5 & 92.0 & 92.1 & 98.4 & 101.5 \\
\hline & ARM-71a & 66.0 & 73.6 & 86.5 & 87.4 & 92.8 & 95.8 \\
\hline & HPR-2A & 72.8 & 79.2 & 91.3 & 91.2 & 98.7 & 102.0 \\
\hline & $\mathrm{R}-410 \mathrm{~A}$ rerun & 61.4 & 68.3 & 78.9 & 78.9 & 85.8 & 89.4 \\
\hline \multirow{7}{*}{$\begin{array}{c}\text { Liquid Line } \\
\text { Temperature, } \\
{ }^{\circ} \mathrm{C}\end{array}$} & $\mathrm{R}-410 \mathrm{~A}$ & 28.8 & 36.7 & 49.2 & 49.2 & 55.4 & 58.7 \\
\hline & $\mathrm{R}-32$ & 29.3 & 36.8 & 50.6 & 50.6 & 57.3 & 60.1 \\
\hline & DR-55 & 28.1 & 35.9 & 48.6 & 49.4 & 56.2 & 59.5 \\
\hline & L-41 (R-447A) & 28.7 & 36.8 & 49.7 & 49.6 & 55.9 & 58.8 \\
\hline & ARM-71a & 29.5 & 37.7 & 50.5 & 50.5 & 56.7 & 59.3 \\
\hline & HPR-2A & 28.7 & 36.3 & 49.1 & 49.1 & 56.0 & 59.2 \\
\hline & $\mathrm{R}-410 \mathrm{~A}$ rerun & 28.8 & 36.8 & 49.6 & 49.5 & 56.3 & 59.6 \\
\hline \multirow{7}{*}{$\begin{array}{l}\text { Liquid Line } \\
\text { Pressure, } \\
\text { MPa } \\
\text { (absolute) }\end{array}$} & $\mathrm{R}-410 \mathrm{~A}$ & 2.20 & 2.59 & 3.26 & 3.26 & 3.66 & 3.88 \\
\hline & $\mathrm{R}-32$ & 2.22 & 2.61 & 3.36 & 3.35 & 3.80 & 4.03 \\
\hline & DR-55 & 2.06 & 2.43 & 3.09 & 3.11 & 3.53 & 3.74 \\
\hline & L-41 (R-447A) & 1.91 & 2.27 & 2.90 & 2.90 & 3.29 & 3.50 \\
\hline & ARM-71a & 2.00 & 2.36 & 3.00 & 3.01 & 3.41 & 3.62 \\
\hline & HPR-2A & 1.98 & 2.35 & 3.00 & 3.00 & 3.40 & 3.61 \\
\hline & $\mathrm{R}-410 \mathrm{~A}$ rerun & 2.18 & 2.57 & 3.25 & 3.25 & 3.67 & 3.90 \\
\hline \multirow{7}{*}{$\begin{array}{l}\text { Evaporator } \\
\text { Inlet } \\
\text { Temperature, } \\
{ }^{\circ} \mathrm{C}\end{array}$} & $\mathrm{R}-410 \mathrm{~A}$ & 8.9 & 10.9 & 13.1 & 13.2 & 14.6 & 15.3 \\
\hline & $\mathrm{R}-32$ & 8.4 & 10.5 & 12.2 & 12.3 & 13.6 & 14.2 \\
\hline & DR-55 & 13.1 & 14.2 & 13.0 & 39.2 & 42.5 & 43.5 \\
\hline & L-41 (R-447A) & 5.8 & 8.3 & 10.8 & 10.7 & 12.3 & 13.3 \\
\hline & ARM-71a & 10.2 & 11.3 & 19.2 & 22.7 & 39.1 & 39.7 \\
\hline & HPR-2A & 6.2 & 8.9 & 11.1 & 11.2 & 12.4 & 13.2 \\
\hline & $\mathrm{R}-410 \mathrm{~A}$ rerun & 8.8 & 10.9 & 13.2 & 13.6 & 14.9 & 15.8 \\
\hline
\end{tabular}


Table E.1. (continued)

\begin{tabular}{|c|c|c|c|c|c|c|c|}
\hline & \multirow{2}{*}{ Refrigerant } & \multicolumn{6}{|c|}{ Test conditions } \\
\hline & & B & A & T3* & T3 & Hot & Extreme \\
\hline \multirow{7}{*}{$\begin{array}{l}\text { Evaporator } \\
\text { Inlet } \\
\text { Pressure, } \\
\text { MPa } \\
\text { (absolute) }\end{array}$} & $\mathrm{R}-410 \mathrm{~A}$ & 1.055 & 1.123 & 1.197 & 1.200 & 1.245 & 1.272 \\
\hline & $\mathrm{R}-32$ & 1.024 & 1.094 & 1.157 & 1.157 & 1.205 & 1.230 \\
\hline & DR-55 & 0.983 & 1.047 & 1.113 & 1.116 & 1.158 & 1.177 \\
\hline & L-41 (R-447A) & 0.838 & 0.907 & 0.977 & 0.977 & 1.020 & 1.044 \\
\hline & ARM-71a & 0.966 & 1.004 & 1.070 & 1.079 & 1.117 & 1.143 \\
\hline & HPR-2A & 0.867 & 0.948 & 1.013 & 1.013 & 1.049 & 1.073 \\
\hline & $\mathrm{R}-410 \mathrm{~A}$ rerun & 1.041 & 1.110 & 1.184 & 1.187 & 1.234 & 1.262 \\
\hline \multirow{7}{*}{$\begin{array}{c}\text { Evaporator } \\
\text { Outlet } \\
\text { Temperature, } \\
{ }^{\circ} \mathrm{C}\end{array}$} & $\mathrm{R}-410 \mathrm{~A}$ & 12.7 & 12.6 & 11.0 & 11.1 & 11.8 & 12.4 \\
\hline & $\mathrm{R}-32$ & 12.8 & 12.3 & 10.8 & 10.9 & 11.4 & 11.9 \\
\hline & DR-55 & 13.1 & 13.1 & 11.4 & 11.7 & 12.3 & 12.4 \\
\hline & $\mathrm{L}-41$ (R-447A) & 14.0 & 14.1 & 13.8 & 13.9 & 13.2 & 13.5 \\
\hline & ARM-71a & 13.3 & 13.4 & 12.2 & 12.1 & 12.6 & 13.0 \\
\hline & HPR-2A & 13.5 & 13.5 & 11.8 & 11.7 & 12.3 & 12.8 \\
\hline & $\mathrm{R}-410 \mathrm{~A}$ rerun & 12.5 & 12.4 & 10.7 & 10.8 & 11.5 & 12.1 \\
\hline \multirow{7}{*}{$\begin{array}{l}\text { Evaporator } \\
\text { Outlet } \\
\text { Pressure, } \\
\text { MPa } \\
\text { (absolute) }\end{array}$} & $\mathrm{R}-410 \mathrm{~A}$ & 0.998 & 1.052 & 1.103 & 1.105 & 1.137 & 1.159 \\
\hline & $\mathrm{R}-32$ & 0.989 & 1.050 & 1.097 & 1.098 & 1.137 & 1.158 \\
\hline & DR-55 & 0.940 & 0.994 & 1.040 & 1.044 & 1.075 & 1.089 \\
\hline & L-41 (R-447A) & 0.800 & 0.861 & 0.916 & 0.916 & 0.950 & 0.969 \\
\hline & ARM-71a & 0.923 & 0.951 & 1.000 & 1.009 & 1.036 & 1.056 \\
\hline & HPR-2A & 0.832 & 0.904 & 0.953 & 0.953 & 0.981 & 1.000 \\
\hline & $\mathrm{R}-410 \mathrm{~A}$ rerun & 0.985 & 1.041 & 1.091 & 1.093 & 1.127 & 1.150 \\
\hline \multirow{7}{*}{$\begin{array}{l}\text { Compressor } \\
\text { Suction } \\
\text { Temperature, } \\
{ }^{\circ} \mathrm{C}\end{array}$} & $\mathrm{R}-410 \mathrm{~A}$ & 14.7 & 15.5 & 14.5 & 13.0 & 14.1 & 13.0 \\
\hline & $\mathrm{R}-32$ & 14.9 & 15.3 & 15.1 & 15.3 & 15.7 & 13.8 \\
\hline & DR-55 & 15.6 & 16.1 & 16.5 & 15.2 & 17.3 & 15.7 \\
\hline & $\mathrm{L}-41$ (R-447A) & 16.9 & 18.2 & 20.0 & 20.0 & 19.6 & 18.7 \\
\hline & ARM-71a & 17.1 & 17.9 & 16.2 & 18.0 & 14.9 & 14.9 \\
\hline & HPR-2A & 15.9 & 18.5 & 18.4 & 18.2 & 14.4 & 15.1 \\
\hline & $\mathrm{R}-410 \mathrm{~A}$ rerun & 15.7 & 17.3 & 13.7 & 13.7 & 13.5 & 14.3 \\
\hline
\end{tabular}


Table E.1. (continued)

\begin{tabular}{|c|c|c|c|c|c|c|c|}
\hline & \multirow{2}{*}{ Refrigerant } & \multicolumn{6}{|c|}{ Test conditions } \\
\hline & & B & A & T3* & T3 & Hot & Extreme \\
\hline \multirow{7}{*}{$\begin{array}{l}\text { Saturation } \\
\text { Temperature, } \\
\text { Liquid Line, } \\
{ }^{\circ} \mathrm{C}\end{array}$} & $\mathrm{R}-410 \mathrm{~A}$ & 36.1 & 42.8 & 52.7 & 52.7 & 57.8 & 60.4 \\
\hline & $\mathrm{R}-32$ & 35.6 & 42.1 & 52.9 & 52.8 & 58.5 & 61.1 \\
\hline & DR-55 & 34.9 & 41.7 & 52.0 & 52.4 & 58.0 & 60.6 \\
\hline & L-41 (R-447A) & 34.4 & 41.6 & 52.2 & 52.1 & 57.9 & 60.8 \\
\hline & ARM-71a & 34.9 & 41.7 & 52.1 & 52.1 & 57.8 & 60.5 \\
\hline & HPR-2A & 34.6 & 41.6 & 52.0 & 52.0 & 57.7 & 60.5 \\
\hline & $\mathrm{R}-410 \mathrm{~A}$ rerun & 35.7 & 42.3 & 52.5 & 52.5 & 58.0 & 60.6 \\
\hline \multirow{7}{*}{$\begin{array}{c}\text { Saturation } \\
\text { Temperature, } \\
\text { Evaporator } \\
\text { Inlet, } \\
{ }^{\circ} \mathrm{C}\end{array}$} & $\mathrm{R}-410 \mathrm{~A}$ & 9.0 & 11.2 & 13.4 & 13.4 & 14.7 & 15.5 \\
\hline & $\mathrm{R}-32$ & 7.4 & 9.6 & 11.5 & 11.5 & 12.9 & 13.6 \\
\hline & DR-55 & 9.0 & 11.1 & 13.2 & 13.3 & 14.6 & 15.2 \\
\hline & L-41 (R-447A) & 9.4 & 11.9 & 14.4 & 14.4 & 15.8 & 16.6 \\
\hline & ARM-71a & 10.2 & 11.5 & 13.7 & 14.0 & 15.2 & 16.0 \\
\hline & HPR-2A & 8.3 & 11.2 & 13.4 & 13.4 & 14.6 & 15.3 \\
\hline & $\mathrm{R}-410 \mathrm{~A}$ rerun & 8.6 & 10.8 & 13.0 & 13.1 & 14.4 & 15.2 \\
\hline \multirow{7}{*}{$\begin{array}{c}\text { Saturation } \\
\text { Temperature, } \\
\text { Evaporator } \\
\text { Outlet, } \\
{ }^{\circ} \mathrm{C}\end{array}$} & $\mathrm{R}-410 \mathrm{~A}$ & 7.2 & 9.0 & 10.6 & 10.6 & 11.6 & 12.2 \\
\hline & $\mathrm{R}-32$ & 6.3 & 8.3 & 9.7 & 9.7 & 10.9 & 11.5 \\
\hline & DR-55 & 7.5 & 9.4 & 10.9 & 11.0 & 12.0 & 12.5 \\
\hline & L-41 (R-447A) & 7.9 & 10.3 & 12.3 & 12.3 & 13.5 & 14.1 \\
\hline & ARM-71a & 8.7 & 9.7 & 11.4 & 11.7 & 12.6 & 13.2 \\
\hline & HPR-2A & 7.0 & 9.7 & 11.4 & 11.4 & 12.3 & 13.0 \\
\hline & $\mathrm{R}-410 \mathrm{~A}$ rerun & 6.8 & 8.6 & 10.2 & 10.3 & 11.3 & 12.0 \\
\hline \multirow{7}{*}{$\begin{array}{c}\text { Saturation } \\
\text { Temperature, } \\
\text { Compressor } \\
\text { Discharge, } \\
{ }^{\circ} \mathrm{C}\end{array}$} & $\mathrm{R}-410 \mathrm{~A}$ & 36.2 & 42.9 & 52.8 & 52.8 & 57.9 & 60.5 \\
\hline & R-32 & 35.6 & 42.1 & 52.9 & 52.8 & 58.5 & 61.1 \\
\hline & DR-55 & 36.2 & 43.0 & 53.1 & 53.5 & 59.0 & 61.6 \\
\hline & L-41 (R-447A) & 38.5 & 45.4 & 55.6 & 55.6 & 61.1 & 63.7 \\
\hline & ARM-71a & 36.8 & 43.5 & 53.7 & 53.8 & 59.3 & 62.0 \\
\hline & HPR-2A & 37.5 & 44.4 & 54.5 & 54.5 & 59.9 & 62.6 \\
\hline & $\mathrm{R}-410 \mathrm{~A}$ rerun & 35.8 & 42.4 & 52.6 & 52.6 & 58.1 & 60.7 \\
\hline
\end{tabular}


Table E.1. (continued)

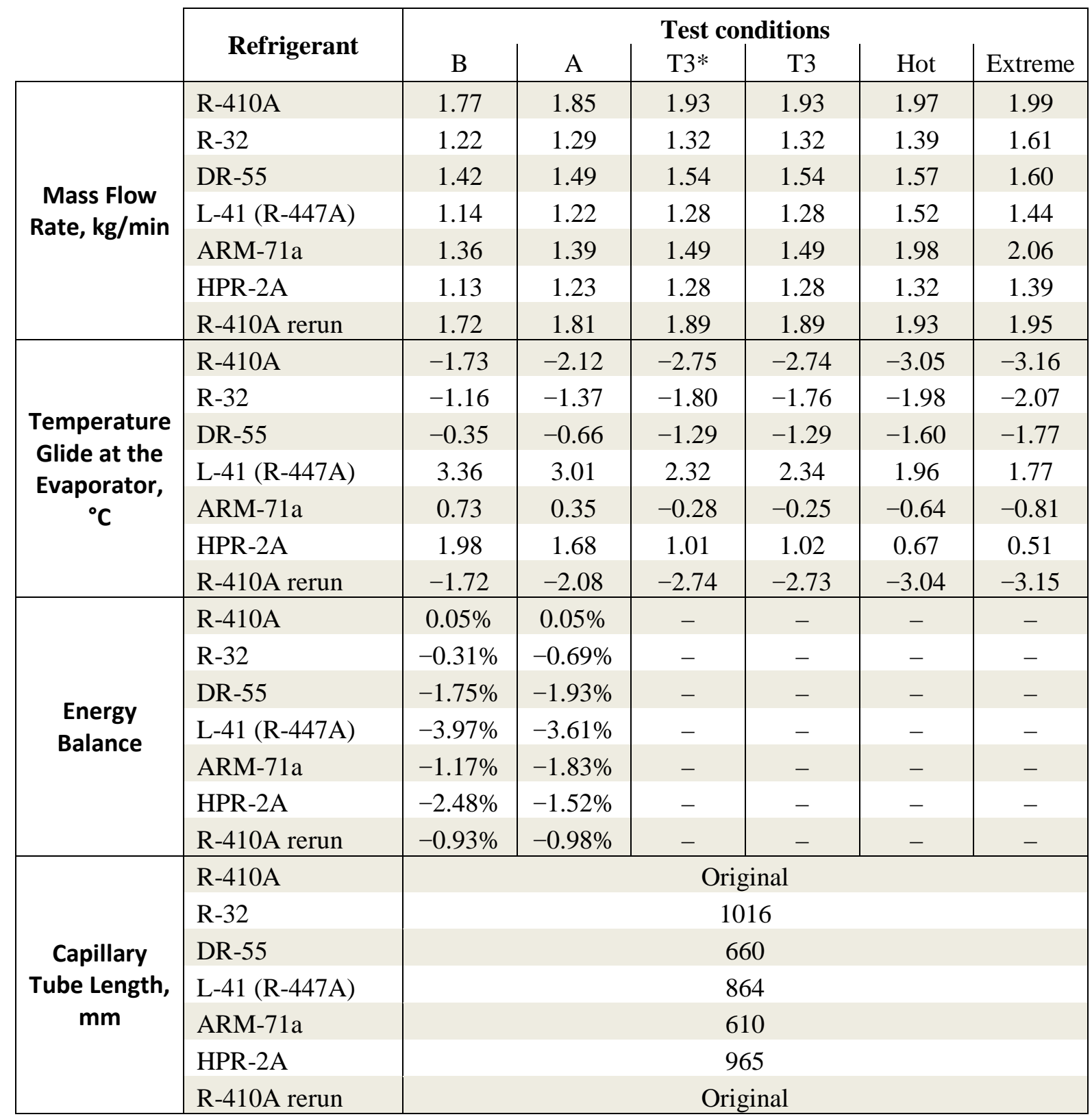


Table E.1. (continued)

\begin{tabular}{|c|c|c|c|c|c|c|c|}
\hline & \multirow{2}{*}{ Refrigerant } & \multicolumn{6}{|c|}{ Test conditions } \\
\hline & & B & A & T3* & T3 & Hot & Extreme \\
\hline \multirow{7}{*}{$\begin{array}{c}\text { Refrigerant } \\
\text { Charge, kg }\end{array}$} & R-410A & \multicolumn{6}{|c|}{0.936} \\
\hline & R-32 & \multicolumn{6}{|c|}{0.709} \\
\hline & DR-55 & \multicolumn{6}{|c|}{0.811} \\
\hline & L-41 (R-447A) & \multicolumn{6}{|c|}{0.780} \\
\hline & ARM-71a & \multicolumn{6}{|c|}{0.765} \\
\hline & HPR-2A & \multicolumn{6}{|c|}{0.808} \\
\hline & $\mathrm{R}-410 \mathrm{~A}$ rerun & \multicolumn{6}{|c|}{0.936} \\
\hline
\end{tabular}

Table E.2. Additional test data for the R-410A unit with the original capillary tube

\begin{tabular}{|c|c|c|c|c|}
\hline & \multirow{2}{*}{ Refrigerant } & \multicolumn{3}{|c|}{ Test conditions } \\
\hline & & A & T3 & Extreme \\
\hline \multirow{6}{*}{$\begin{array}{c}\text { Cooling } \\
\text { Capacity } \\
\text { (air-side), } \\
\text { kW }\end{array}$} & $\mathrm{R}-410 \mathrm{~A}$ & 5.14 & 4.41 & 3.75 \\
\hline & $\mathrm{R}-32$ & 5.18 & 4.50 & 3.74 \\
\hline & DR-55 & 4.88 & 4.22 & 3.66 \\
\hline & L-41 (R-447A) & 4.29 & 3.77 & 3.38 \\
\hline & ARM-71a & 4.68 & 4.08 & 3.53 \\
\hline & HPR-2A & 4.49 & 3.93 & 3.51 \\
\hline \multirow{6}{*}{$\begin{array}{l}\text { COP (air- } \\
\text { side) }\end{array}$} & $\mathrm{R}-410 \mathrm{~A}$ & 3.40 & 2.49 & 1.87 \\
\hline & $\mathrm{R}-32$ & 3.39 & 2.45 & 1.76 \\
\hline & DR-55 & 3.43 & 2.50 & 1.89 \\
\hline & L-41 (R-447A) & 3.17 & 2.37 & 1.86 \\
\hline & ARM-71a & 3.33 & 2.47 & 1.85 \\
\hline & HPR-2A & 3.22 & 2.39 & 1.86 \\
\hline \multirow{6}{*}{$\begin{array}{c}\text { Condenser } \\
\text { Subcooling, } \\
{ }^{\circ} \mathrm{C}\end{array}$} & $\mathrm{R}-410 \mathrm{~A}$ & 6.058 & 3.472 & 1.758 \\
\hline & $\mathrm{R}-32$ & 0.496 & 0.220 & 0.174 \\
\hline & DR-55 & 2.440 & 0.799 & 0.694 \\
\hline & $\mathrm{L}-41$ (R-447A) & 1.188 & 0.945 & 0.697 \\
\hline & ARM-71a & 1.803 & 1.198 & 1.015 \\
\hline & HPR-2A & 1.241 & 0.927 & 0.660 \\
\hline \multirow{6}{*}{$\begin{array}{c}\text { Evaporator } \\
\text { Superheat, } \\
{ }^{\circ} \mathrm{C}\end{array}$} & $\mathrm{R}-410 \mathrm{~A}$ & 3.612 & 0.492 & 0.138 \\
\hline & $\mathrm{R}-32$ & 3.995 & 0.476 & 0.024 \\
\hline & DR-55 & 3.759 & 0.548 & -0.081 \\
\hline & L-41 (R-447A) & 3.822 & 0.493 & -0.006 \\
\hline & ARM-71a & 3.570 & 0.160 & -0.365 \\
\hline & HPR-2A & 3.957 & 0.273 & -0.279 \\
\hline
\end{tabular}


Table E.2. (continued)

\begin{tabular}{|c|c|c|c|c|}
\hline & \multirow{3}{*}{ Refrigerant } & \multirow{2}{*}{\multicolumn{3}{|c|}{ Test conditions }} \\
\hline & & & & \\
\hline & & A & T3 & Extreme \\
\hline \multirow{6}{*}{$\begin{array}{l}\text { Compressor } \\
\text { Discharge } \\
\text { Temperature, } \\
{ }^{\circ} \mathrm{C}\end{array}$} & $\mathrm{R}-410 \mathrm{~A}$ & 68.0 & 78.4 & 87.6 \\
\hline & $\mathrm{R}-32$ & 79.5 & 92.1 & 100.8 \\
\hline & DR-55 & 71.7 & 83.3 & 92.0 \\
\hline & $\mathrm{L}-41$ (R-447A) & 75.9 & 86.6 & 96.1 \\
\hline & ARM-71a & 73.0 & 84.0 & 93.2 \\
\hline & HPR-2A & 77.8 & 89.4 & 99.0 \\
\hline \multirow{6}{*}{$\begin{array}{c}\text { Liquid Line } \\
\text { Temperature, } \\
{ }^{\circ} \mathrm{C}\end{array}$} & $\mathrm{R}-410 \mathrm{~A}$ & 36.7 & 49.2 & 58.7 \\
\hline & $\mathrm{R}-32$ & 41.3 & 52.0 & 60.0 \\
\hline & DR-55 & 39.0 & 51.0 & 59.4 \\
\hline & $\mathrm{L}-41(\mathrm{R}-447 \mathrm{~A})$ & 39.0 & 49.7 & 58.4 \\
\hline & ARM-71a & 39.6 & 50.6 & 59.2 \\
\hline & HPR-2A & 39.4 & 50.2 & 58.8 \\
\hline \multirow{6}{*}{$\begin{array}{l}\text { Liquid Line } \\
\text { Pressure, } \\
\text { MPa } \\
\text { (absolute) }\end{array}$} & $\mathrm{R}-410 \mathrm{~A}$ & 2.59 & 3.26 & 3.88 \\
\hline & $\mathrm{R}-32$ & 2.59 & 3.31 & 3.95 \\
\hline & DR-55 & 2.42 & 3.08 & 3.69 \\
\hline & $\mathrm{L}-41$ (R-447A) & 2.19 & 2.80 & 3.38 \\
\hline & ARM-71a & 2.35 & 2.99 & 3.59 \\
\hline & HPR-2A & 2.30 & 2.93 & 3.53 \\
\hline \multirow{6}{*}{$\begin{array}{l}\text { Evaporator } \\
\text { Inlet } \\
\text { Temperature, } \\
{ }^{\circ} \mathrm{C}\end{array}$} & $\mathrm{R}-410 \mathrm{~A}$ & 10.95 & 13.19 & 15.31 \\
\hline & $\mathrm{R}-32$ & 11.22 & 16.02 & 17.72 \\
\hline & DR-55 & 35.16 & 39.22 & 31.61 \\
\hline & L-41 (R-447A) & 9.26 & 12.61 & 15.50 \\
\hline & ARM-71a & 9.02 & 11.44 & 13.56 \\
\hline & HPR-2A & 9.92 & 12.83 & 15.47 \\
\hline \multirow{6}{*}{$\begin{array}{l}\text { Evaporator } \\
\text { Inlet } \\
\text { Pressure, } \\
\text { MPa } \\
\text { (absolute) }\end{array}$} & $\mathrm{R}-410 \mathrm{~A}$ & 1.123 & 1.200 & 1.272 \\
\hline & R-32 & 1.119 & 1.207 & 1.286 \\
\hline & DR-55 & 1.057 & 1.135 & 1.200 \\
\hline & L-41 (R-447A) & 0.916 & 0.992 & 1.072 \\
\hline & ARM-71a & 1.013 & 1.092 & 1.163 \\
\hline & HPR-2A & 0.963 & 1.043 & 1.125 \\
\hline
\end{tabular}


Table E.2. (continued)

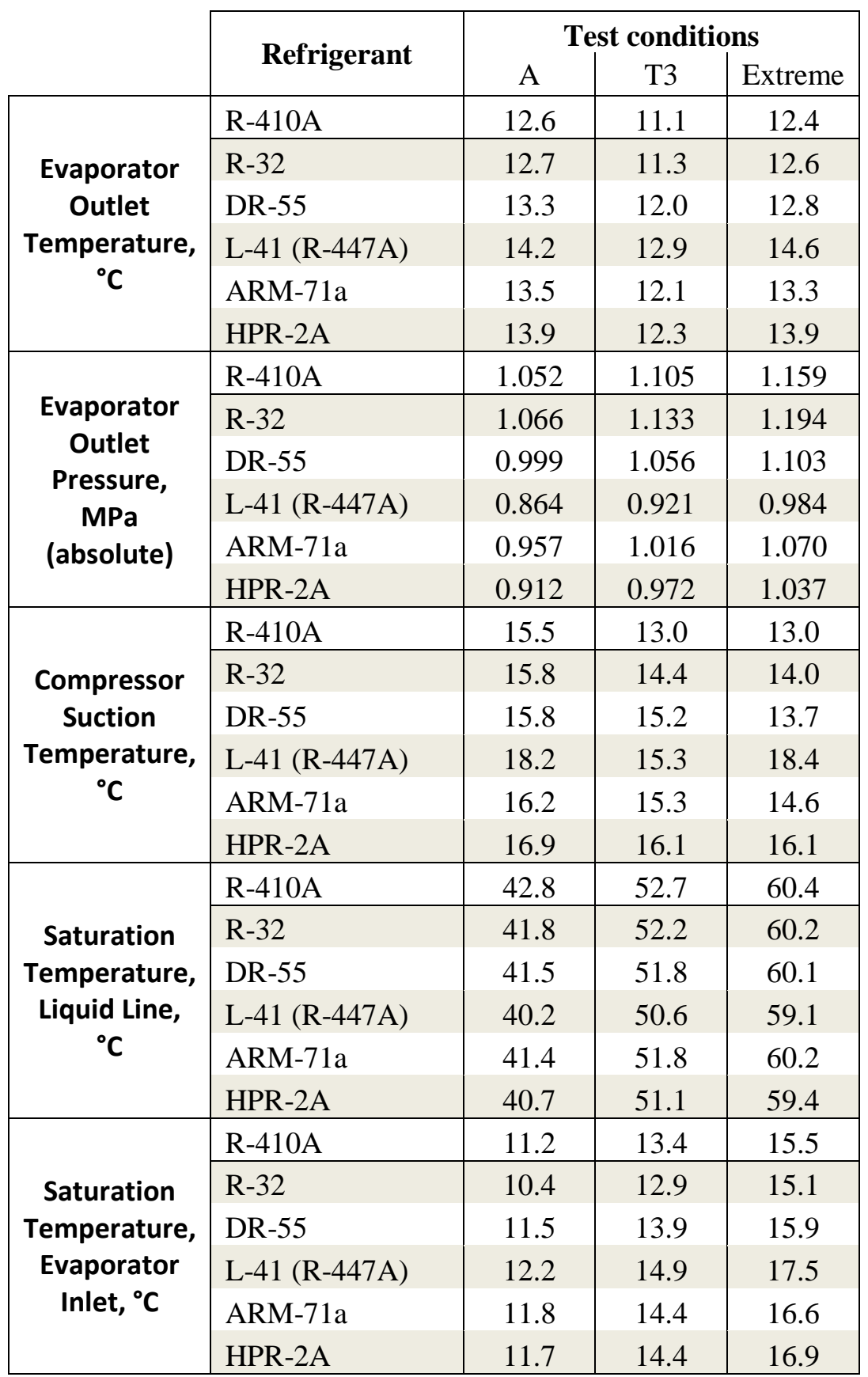


Table E.2. (continued)

\begin{tabular}{|c|c|c|c|c|}
\hline & \multirow{3}{*}{ Refrigerant } & \multirow{2}{*}{\multicolumn{3}{|c|}{ Test conditions }} \\
\hline & & & & \\
\hline & & A & T3 & Extreme \\
\hline \multirow{6}{*}{$\begin{array}{l}\text { Saturation } \\
\text { Temperature, } \\
\text { Evaporator } \\
\text { Outlet, }{ }^{\circ} \mathrm{C}\end{array}$} & $\mathrm{R}-410 \mathrm{~A}$ & 8.96 & 10.62 & 12.24 \\
\hline & $\mathrm{R}-32$ & 8.73 & 10.78 & 12.57 \\
\hline & DR-55 & 9.52 & 11.41 & 12.90 \\
\hline & L-41 (R-447A) & 10.35 & 12.45 & 14.61 \\
\hline & ARM-71a & 9.91 & 11.92 & 13.67 \\
\hline & HPR-2A & 9.96 & 12.03 & 14.18 \\
\hline \multirow{6}{*}{$\begin{array}{l}\text { Saturation } \\
\text { Temperature, } \\
\text { Compressor } \\
\text { Discharge, }{ }^{\circ} \mathrm{C}\end{array}$} & $\mathrm{R}-410 \mathrm{~A}$ & 42.9 & 52.8 & 60.5 \\
\hline & $\mathrm{R}-32$ & 41.8 & 52.2 & 60.2 \\
\hline & DR-55 & 42.7 & 53.0 & 61.1 \\
\hline & L-41 (R-447A) & 44.0 & 54.1 & 62.2 \\
\hline & ARM-71a & 43.3 & 53.5 & 61.6 \\
\hline & HPR-2A & 43.4 & 53.6 & 61.6 \\
\hline \multirow{6}{*}{$\begin{array}{l}\text { Mass Flow } \\
\text { Rate, kg/min }\end{array}$} & $\mathrm{R}-410 \mathrm{~A}$ & 1.85 & 1.93 & 1.99 \\
\hline & $\mathrm{R}-32$ & 1.10 & 1.26 & 1.36 \\
\hline & DR-55 & 1.49 & 1.82 & 1.55 \\
\hline & $\mathrm{L}-41$ (R-447A) & 0.65 & 0.82 & 1.31 \\
\hline & ARM-71a & 1.47 & 1.71 & 1.99 \\
\hline & HPR-2A & 0.32 & 1.09 & 1.25 \\
\hline \multirow{6}{*}{$\begin{array}{c}\text { Temperature } \\
\text { Glide at the } \\
\text { Evaporator, } \\
{ }^{\circ} \mathrm{C}\end{array}$} & $\mathrm{R}-410 \mathrm{~A}$ & -2.12 & -2.74 & -3.16 \\
\hline & $\mathrm{R}-32$ & -1.64 & -2.16 & -2.58 \\
\hline & DR-55 & -0.85 & -1.48 & -2.02 \\
\hline & L-41 (R-447A) & 2.75 & 1.99 & 1.37 \\
\hline & ARM-71a & 0.24 & -0.44 & -0.99 \\
\hline & HPR-2A & 1.39 & 0.68 & 0.10 \\
\hline \multirow{6}{*}{$\begin{array}{l}\text { Energy } \\
\text { Balance }\end{array}$} & $\mathrm{R}-410 \mathrm{~A}$ & $0.05 \%$ & - & - \\
\hline & R-32 & - & - & - \\
\hline & DR-55 & $-1.76 \%$ & - & - \\
\hline & L-41 (R-447A) & - & - & - \\
\hline & ARM-71a & $3.58 \%$ & - & - \\
\hline & HPR-2A & - & - & - \\
\hline
\end{tabular}


Table E.2. (continued)

\begin{tabular}{|c|c|c|c|c|}
\hline & \multirow{2}{*}{ Refrigerant } & \multicolumn{3}{|c|}{ Test conditions } \\
\hline & & A & Т3 & Extreme \\
\hline \multirow{6}{*}{$\begin{array}{l}\text { Refrigerant } \\
\text { Charge, kg }\end{array}$} & $\mathrm{R}-410 \mathrm{~A}$ & \multicolumn{3}{|c|}{0.936} \\
\hline & $\mathrm{R}-32$ & \multicolumn{3}{|c|}{0.644} \\
\hline & DR-55 & \multicolumn{3}{|c|}{0.731} \\
\hline & L-41 (R-447A) & \multicolumn{3}{|c|}{0.737} \\
\hline & ARM-71a & \multicolumn{3}{|c|}{0.746} \\
\hline & HPR-2A & \multicolumn{3}{|c|}{0.751} \\
\hline
\end{tabular}


E-20 
APPENDIX F. DATA REDUCTION METHODOLOGY 



\section{APPENDIX F. DATA REDUCTION METHODOLOGY}

The measured data obtained using the instrumentation listed in APPENDIX $\mathrm{C}$ were recorded using a National Instrument data acquisition system. Data were recorded continually at 5 second intervals. LabView ${ }^{\circledR}$ code was developed to allow for real-time data visualization and performance monitoring, as shown in Figure F.1 and Figure F.2. REFPROP property calculations were included in the code, as shown in Figure F.3, to facilitate the real-time evaluation of the refrigerant side properties, e.g., saturation properties and capacity. The airflow, air-side capacity, refrigerant-side capacity, and refrigerant subcooling and superheat calculations are presented in the following sections. Table F.1 shows the symbols, and Table F. 2 shows the subscripts used in the calculations.

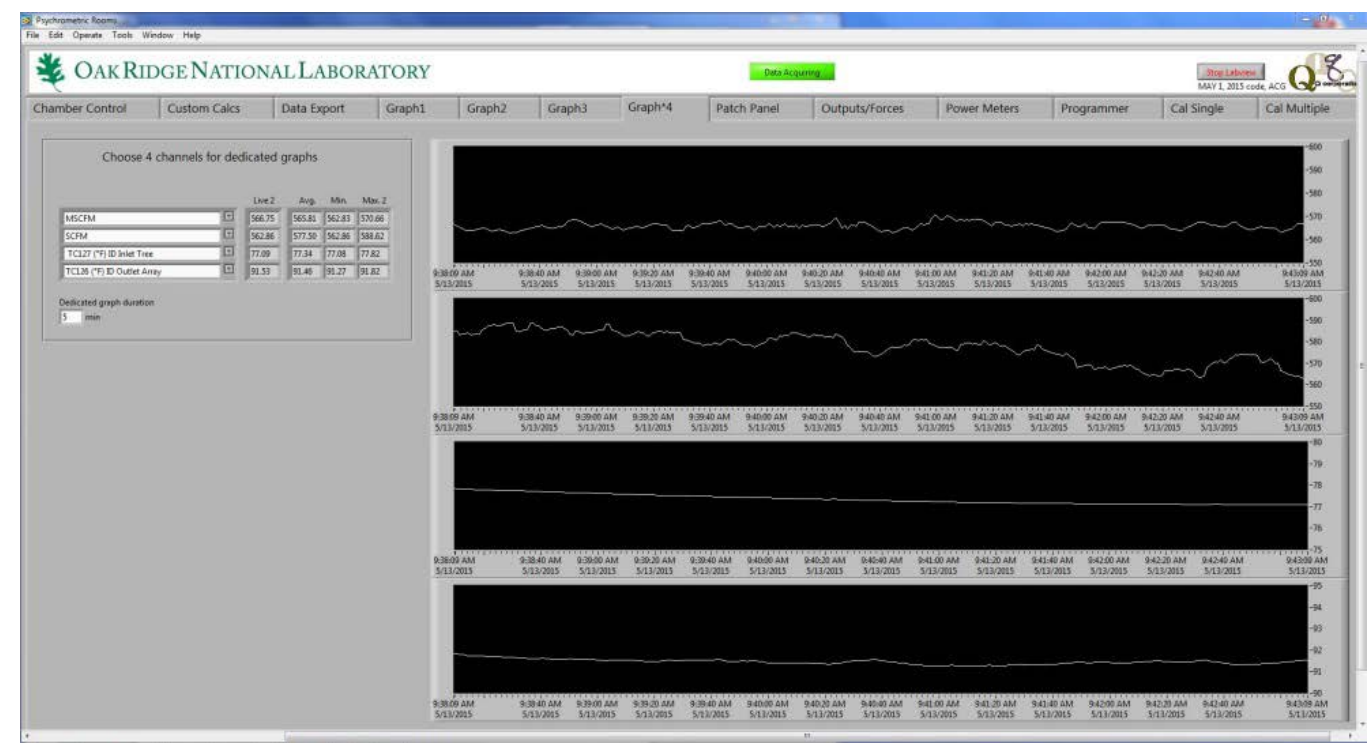

Figure F.1. LabView ${ }^{\circledR}$ display of room temperature and fan flow rate.

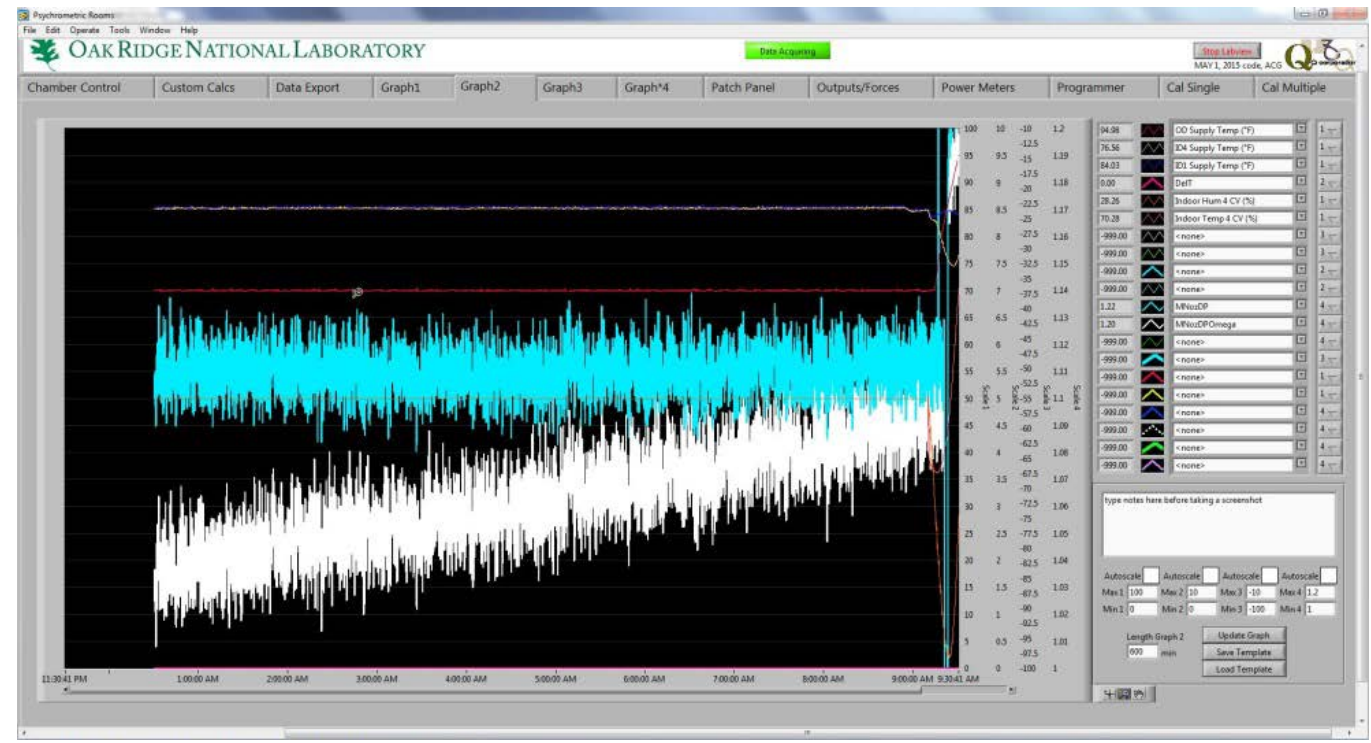

Figure F.2. LabView ${ }^{\circledR}$ display of various monitored parameters. 


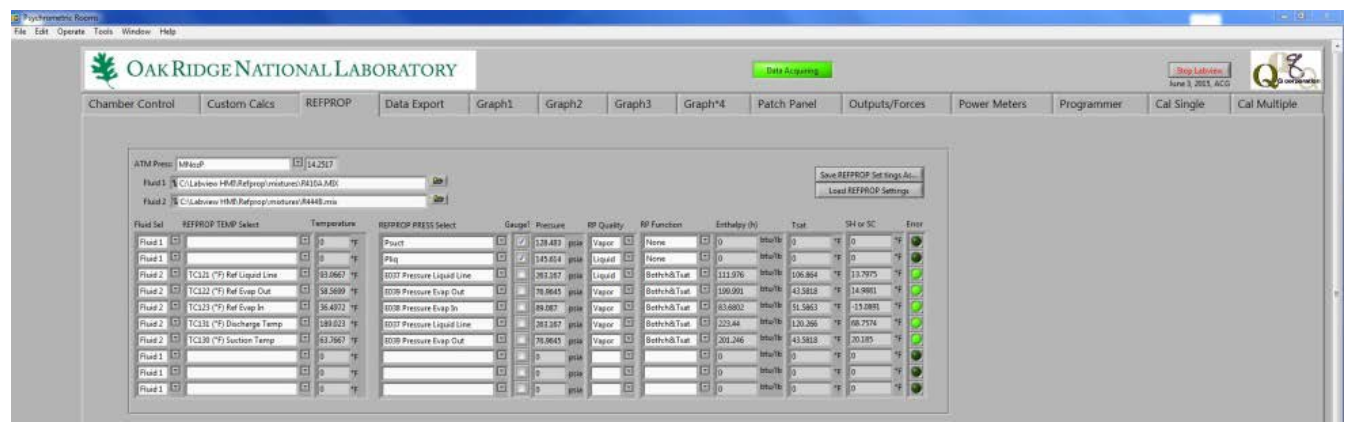

Figure F.3. LabView ${ }^{\circledR}$ display of built-in REFPROP calculation.

Table F.1. Data reduction methodology symbols

\begin{tabular}{|c|c|c|}
\hline Symbol & Description & Unit \\
\hline$A_{\text {nozzle }}$ & Area of cross section at the nozzle throat & $\mathrm{ft}^{2}$ \\
\hline$C_{\text {nozzle }}$ & Nozzle discharge coefficient & - \\
\hline$C_{p}$ & Specific heat & $\mathrm{Btu} / \mathrm{lbm} \cdot{ }^{\circ} \mathrm{F}$ \\
\hline$D$ & Diameter & in. \\
\hline$h$ & Enthalpy & $\mathrm{Btu} / \mathrm{lbm}$ \\
\hline$L$ & Side & in. \\
\hline$\dot{m}$ & Flow rate & $\mathrm{lbm} / \mathrm{h}$ \\
\hline$P$ & Absolute pressure & $\mathrm{inH}_{2} \mathrm{O}$ \\
\hline$q$ & Heat capacity & Btu/h \\
\hline$Q$ & Airflow rate & $\mathrm{cfm}$ \\
\hline$Q_{s}$ & Standard airflow rate & $\operatorname{scfm}$ \\
\hline$R e$ & Reynolds number & - \\
\hline$T$ & Dry bulb temperature & ${ }^{\circ} \mathrm{F}$ \\
\hline$Y$ & Expansion factor & - \\
\hline$W$ & Electric power & Watt \\
\hline$\alpha$ & $\begin{array}{l}\text { Ratio of the absolute pressure at exit } \\
\text { from the nozzle to the absolute pressure } \\
\text { entering the nozzle }\end{array}$ & - \\
\hline$\beta$ & $\begin{array}{l}\text { Ratio of nozzle throat diameter to duct } \\
\text { diameter }\end{array}$ & - \\
\hline$\Delta$ & Differential & in. $\mathrm{H}_{2} \mathrm{O},{ }^{\circ} \mathrm{F}$ \\
\hline$\mu$ & Moist air humidity ratio & $\mathrm{lb} \mathrm{H}_{2} \mathrm{O} / \mathrm{lb}$ air \\
\hline$\rho$ & Moist air density & $\mathrm{lbm} / \mathrm{ft}^{3}$ \\
\hline
\end{tabular}


Table F.2. Data reduction methodology subscripts

\begin{tabular}{|c|c|}
\hline Subscript & Description \\
\hline air & Air side \\
\hline compressor & Compressor \\
\hline condensate & Condensate collected from the evaporator \\
\hline condenser fan & Condenser fan \\
\hline duct & Related to the duct \\
\hline evaporator fan & Evaporator fan \\
\hline evap, in & Evaporator inlet conditions \\
\hline evap, out & Evaporator outlet conditions \\
\hline exit & Exiting the nozzle \\
\hline latent & Latent capacity \\
\hline nozzle & Nozzle condition \\
\hline ref & Refrigerant side \\
\hline coil & At the coil \\
\hline return & Return air to the indoor unit \\
\hline sat & Saturated conditions at the equilibrium \\
\hline subcooling & Degrees of subcooling \\
\hline superheat & Degrees of superheat \\
\hline sensible & Sensible capacity \\
\hline supply & Supply air exiting the indoor unit \\
\hline total & Total capacity \\
\hline tree & From sampling tree \\
\hline upstream & Entering the nozzle \\
\hline
\end{tabular}

\section{Airflow Rate Calculation:}

The airflow rate calculations were performed according to ASHRAE Standard 41.2-87 (RA92). The airflow rate was calculated as shown in Eq. (1). Equations (2) and (5) were used to calculate the expansion factor, $Y$, and the nozzle discharge coefficient, $C_{\text {nozzle }}$, respectively; both of them are inputs to Eq. (1). The expansion factor is in turn a function of two parameters: $\alpha$, the ratio of absolute pressures at the exit and the inlet of the nozzle, and $\beta$, the ratio of nozzle throat diameter to duct diameter. Parameters $\alpha$ and $\beta$ were calculated as shown in Eqs. (3) and (4), respectively. The nozzle discharge coefficient, $C_{n o z z l e}$, was calculated based on $R e$, which can be approximately calculated using Eq. (6), since the airflow velocity is not known. Finally, to evaluate the standard airflow rate, we used Eq. (7) to normalize using the standard dry air density at $70^{\circ} \mathrm{F}$ and $14.696 \mathrm{psia}$ of $0.075 \mathrm{lbm} / \mathrm{ft}^{3}$.

$$
\begin{gathered}
Q=1096 \times Y \times \sqrt{\Delta P_{\text {nozzle }} / \rho_{\text {nozzle }}} \times C_{\text {nozzle }} \times A_{\text {nozzle }} \\
Y=1-\left(0.548+0.71 \times \beta^{4}\right)(1-\alpha) \\
\alpha=\frac{P_{\text {nozzle,exit }}}{P_{\text {nozzle }, \text { upstream }}}
\end{gathered}
$$




$$
\begin{gathered}
\beta=\frac{D_{\text {nozzle }}}{D_{\text {duct }}}=\left(\frac{D_{\text {nozzle }}}{\sqrt{\frac{4}{\pi} \times L_{\text {duct }}^{2}}}\right)=\left(\frac{5}{\sqrt{\frac{4}{\pi} \times 20^{2}}}\right)=0.22155673 \\
C_{\text {nozzle }}=0.9986-\left(\frac{7.006}{\sqrt{R e}}\right)+\left(\frac{134.6}{R e}\right) \\
R e=1,363,000 \times D_{\text {nozzle }} \times \sqrt{\frac{\Delta P \times \rho_{\text {nozzle }}}{1-\beta^{4}}} \\
Q_{S}=\frac{Q \times \rho_{\text {nozzle }}}{\left(1+\mu_{\text {nozzle }}\right)} / 0.075
\end{gathered}
$$

In the above calculations, $\rho_{\text {nozzle }}$ is calculated based on barometric pressure, temperature, and dew point measurement upstream of the nozzle using equations from the ASHRAE Handbook of Fundamentals, 2009, Chapter 1 (Equations 23 and 28). The $P_{\text {nozzle,upstream }}$ is measured using a barometric pressure sensor, and the $P_{\text {nozzle,exit }}$ is calculated using the $P_{\text {nozzle,upstream }}$ and the differential pressure drop across the nozzle, which is measured using a differential pressure sensor and can be calculated as shown in Eq. (8).

$$
P_{\text {nozzle,exit }}=P_{\text {nozzle,upstream }}-\Delta P_{\text {nozzle }}
$$

\section{Air-Side Capacity Calculations:}

Air-side capacity was calculated according to ANSI/ASHRAE Standard 37-2009 Air Enthalpy Method. The total air-side capacity can be calculated as shown in Eq. (9); the supply and return enthalpies used in Eq. (9) were calculated using Eqs. (10) and (11). The factor of 60 was used to convert the airflow rate from $\mathrm{cfm}$ to $\mathrm{ft}^{3} / \mathrm{h}$.

$$
\begin{gathered}
q_{\text {total }}=Q_{s} \times 0.075 \times 60 \times\left(h_{\text {return }}-h_{\text {supply }}\right) \\
h_{\text {return }}=0.24 \times T_{\text {return,tree }}+\mu_{\text {return,tree }} \times\left(1061+0.444 \times T_{\text {return,tree }}\right) \\
h_{\text {supply }}=0.24 \times T_{\text {supply,tree }}+\mu_{\text {supply,tree }} \times\left(1061+0.444 \times T_{\text {supply,tree }}\right)
\end{gathered}
$$

The air-side sensible and latent capacities can be calculated as shown in Eqs. (12) and (15). Also, when the dew point temperature difference is low, it would be more accurate to use the condensate measurement for latent capacity measurement, as shown in Eq. (16).

$$
\begin{aligned}
& q_{\text {sensible }}=Q_{s} \times 0.075 \times 60 \times\left((C p T)_{\text {return }}-(C p T)_{\text {supply }}\right) \\
& (C p T)_{\text {return }}=0.24 \times T_{\text {return,tree }}+\mu_{\text {return,tree }} \times 0.444 \times T_{\text {return,tree }} \\
& (C p T)_{\text {supply }}=0.24 \times T_{\text {supply,tree }}+\mu_{\text {supply,tree }} \times 0.444 \times T_{\text {supply,tree }} \\
& q_{\text {latent }}=Q_{S} \times 0.075 \times 60 \times 1061 \times\left(\mu_{\text {return,tree }}-\mu_{\text {supply,tree }}\right) \\
& q_{\text {latent, condensate }}=\dot{m}_{\text {condensate }} \times 1061
\end{aligned}
$$




\section{Refrigerant-Side Capacity Calculations:}

The refrigerant-side capacity was calculated according to ANSI/ASHRAE Standard 37-2009 Refrigerant Enthalpy Method with refrigerant mass flow measurement. It can be calculated as shown in Eq. (17).

$$
q_{\text {ref,coil }}=\dot{m}_{\text {ref }} \times\left(h_{\text {evap }, \text { out }}-h_{\text {evap }, \text { in }}\right)
$$

In this equation, the refrigerant flow rate, $\dot{m}_{r e f}$, was measured using a Coriolis mass flow meter, and the refrigerant enthalpies were calculated using NIST REFPROP based on pressure and temperature measurements at the evaporator outlet and the condenser liquid line for $h_{\text {evap, out }}$ and $h_{\text {evap, in }}$, respectively. To compare both the air-side and the refrigerant-side capacities, the fan power dissipated into the airstream must be considered: $W_{\text {evaporator } \text { fan }}$.

\section{Efficiency Calculations:}

The EER can be calculated based on the air-side or the refrigerant-side measurements by using Eq. (18) or Eq. (19), respectively. The COP can be obtained from the EER through a unit conversion, as shown in Eqs. (20) and (21) for the air side and the refrigerant side, respectively.

$$
\begin{gathered}
E E R_{\text {air }}=\frac{q_{\text {total }}}{W_{\text {compressor }}+W_{\text {condenser fan }}+W_{\text {evaporator fan }}} \\
E E R_{\text {ref }}=\frac{q_{\text {ref }, \text { coil }}-W_{\text {evaporator fan }}}{W_{\text {compressor }}+W_{\text {condenser fan }}+W_{\text {evaporator fan }}} \\
C O P_{\text {air }}=\frac{E E R_{\text {air }}}{3.4121} \\
C O P_{\text {ref }}=\frac{E E R_{\text {ref }}}{3.4121}
\end{gathered}
$$

\section{Subcooling:}

The liquid line subcooling was calculated based on Eq. (22), in which the saturation temperature, $T_{\text {sat }}$, was calculated using NIST REFPROP based on pressure measurements at the liquid line. The temperature, $T$, was directly measured using an in-stream thermocouple or RTD.

$$
\Delta T_{\text {subcooling }}=T_{\text {sat }}-T
$$

\section{Superheat:}

The evaporator outlet and compressor inlet superheat were calculated based on Eq. (23), in which the saturation temperature, $T_{\text {sat }}$, was calculated using NIST REFPROP based on the pressure at the evaporator outlet. The temperature, $T$, was directly measured at both locations using in-stream thermocouples or RTDs.

$$
\Delta T_{\text {superheat }}=T-T_{\text {sat }}
$$



APPENDIX G. DISCLOSURES OF INTEREST 



\section{APPENDIX G. DISCLOSURES OF INTEREST}

The disclosures of the interests of the panel members are included in this appendix. 


\section{Disclosure of Interest Declaration International Expert Panel for the High-Ambient Testing Program}

Radhey S. Agarwal

Sector Phase-out Plan Unit, Ozone Cell

India

I, Radhey S. Agarwal, residing in New-Delhi, India, as a member of the International Expert Panel for the High Ambient Testing Program, declare as follows:

1) That my responsibilities related to ODS, HFCs, or their alternatives include: I work as a Technical Consultant for implementation of ODS phase-out projects. I am the former Professor of Mechanical Engineering and Dean Industrial Research and Development, Indian Institute of Technology Delhi. I was teaching and guiding $\mathrm{Ph}$. D. research students in the field of refrigeration and Air-Conditioning As an expert of Refrigeration and Air-Conditioning, I provide advise on implementation ODS phase-out projects to various entities. These include organizations dealing with refrigeration and air conditioning issues, and onganizations dealing with Montreal Protocol and UNFCCC related climate issues. Neither I, nor my spouse or my children own stock or have proprietary interest in companies producing HFCs or their alternatives or substitutes.

2) My interests and those of my spouse or children related to ODS, HFCs, or their alternatives include the following:

a. Proprietary interests related to ODS, HFCs, or their alternatives: [None]

b. Financial interests related to ODS, HFCs, or their alternatives: [None]

c. Employment, consultancy, directorship, or other positions related to ODS, HFCs, or their alternatives: [ Technacal Consultant, for implementation of ODS phase-out projects]

d. Government advice and other policy development related to ODS, HFCs, or their alternatives: [ Technical and policy advise on ODS phase-out to Ozone Cell, India]

e. Paid research activities, fellowships, or grants related to ODS, HFCs, or their alternatives: [ None]

f. Other interests related to ODS, HFCs, or their alternatives: [None]

3) I undertake to disclose any material change to any of the above information, within 30 days of any such change.

4) I undertake to make further declarations of interest needed for so long as I remain a member of this Panel.

5) I understand that this Disclosure of Interest will expire no later than one year after I have signed it.

Printed Name: Radhey S. Agarwal

\section{Signature on File}




\section{Disclosure of Interest Declaration}

\section{International Expert Panel for the High-Ambient Testing Program}

\section{Karim Amrane}

Air-Conditioning, Heating, and Refrigeration Institute USA

I, Karim Amrane, residing in Bethesda, Maryland, USA, as a member of the International Expert Panel for the High Ambient Testing Program, declare as follows:

1) That my responsibilities related to ODS, HFCs, or their alternatives include:

- Managing the industry cooperative research program, where I oversee research activities on HVAC technologies including alternative refrigerants to $\mathrm{HFCs}$.

- Developing and implementing AHRI's regulatory and international policy on issues affecting refrigerants including HFCs and their altematives.

- Neither I, nor my spouse or my children own stock or have proprietary interest in companies producing HFCs or their alternatives or substitutes.

2) My interests and those of my spouse or children related to ODS, HFCs, or their alternatives include the following:

a. Proprietary interests related to ODS, HFCs, or their alternatives: None

b. Financial interests related to ODS, HFCs, or their alternatives: None

c. Employment, consultancy, directorship, or other positions related to ODS, HFCs, or their altematives: See above

d. Government advice and other policy development related to ODS, HFCs, or their alternatives: None

e. Paid research activities, fellowships, or grants related to ODS, HFCs, or their alternatives: None

f. Other interests related to ODS, HFCs, or their altematives: None

3) I undertake to disclose any material change to any of the above information, within 30 days of any such change.

4) I undertake to make further declarations of interest needed for so long as I remain a member of this Panel.

5) I understand that this Disclosure of Interest will expire no later than one year after I have signed it.

Printed Name: Karim Amrane

Date: September 6, 2015

Signature: Signature on File 


\title{
Disclosure of Interest Declaration International Expert Panel for the High-Ambient Testing Program
}

\author{
ENIO PEDONE BANDARRA FILHO \\ FEDERAL UNIVERSITY OF UBERLANDIA \\ BRAZIL
}

I, Enio Pedone Bandarra Filho, residing in Uberlandia - Brazil, as a member of the International Expert Panel for the High Ambient Testing Program, declare as follows:

1) That my responsibilities related to ODS, HFCs, or their alternatives include: I work as an associate Professor of Mechanical Engineering, teaching courses and doing research in the fields of thermal sciences and refrigeration and air conditioning, at Federal University of Uberlandia, in Uberlandia, Minas Gerais, Brazil. As an expert of my institution, I consult for various entities. These include organizations dealing with refrigeration and air conditioning issues, and organizations dealing with Montreal Protocol and UNFCCC related climate issues. All consultancies are conducted on a short-term assignment basis. Neither I, nor my spouse or my children own stock or have proprietary interest in companies producing HFCs or their alternatives or substitutes.

2) My interests and those of my spouse or children related to ODS, HFCs, or their alternatives include are related to research in the academy, mainly associated to developments in refrigeration and air conditioning areas with $\mathrm{PhD}$ and Masters students.

3) I undertake to disclose any material change to any of the above information, within 30 days of any such change.

4) I undertake to make further declarations of interest needed for so long as I remain a member of this Panel.

5) I understand that this Disclosure of Interest will expire no later than one year after I have signed it.

\section{Printed Name: ENIO PEDONE BANDARRA FILHO}

Signature on File

Date : MAY, 20th, 2015 


\section{Disclosure of Interest Declaration International Expert Panel for the High-Ambient Testing Program}

ENIO PEDONE BANDARRA FILHO

FEDERAL UNIVERSITY OF UBERLANDIA

BRAZIL

I, Enio Pedone Bandarra Filho, residing in Uberlandia - Brazil, as a member of the International

Expert Panel for the High Ambient Testing Program, declare as follows:

1) That my responsibilities related to ODS, HFCs, or their alternatives include: I work as an associate Professor of Mechanical Engineering, teaching courses and doing research in the fields of thermal sciences and refrigeration and air conditioning, at Federal University of Uberlandia, in Uberlandia, Minas Gerais, Brazil. As an expert of my institution, I consult for various entities. These include organizations dealing with refrigeration and air conditioning issues, and organizations dealing with Montreal Protocol and UNFCCC related climate issues. All consultancies are conducted on a short-term assignment basis, Neither I, nor my spouse or my children own stock or have proprietary interest in companies producing HFCs or their alternatives or substitutes.

2) My interests and those of my spouse or children related to ODS, HFCs, or their alternatives include are related to research in the academy, mainly associated to developments in refrigeration and air conditioning areas with $\mathrm{PhD}$ and Masters students.

3) I undertake to disclose any material change to any of the above information, within 30 days of any such change.

4) I undertake to make further declarations of interest needed for so long as I remain a member of this Panel. 5) I understand that this Disclosure of Interest will expire no later than one year after I have
signed it.

Printed Name: ENIO PEDONE BANDARRA FILHO

Signature on File

Date : MAY, 20th, 2015 


\section{Disclosure of Interest Declaration \\ International Expert Panel for the High-Ambient Testing Program}

Jitendra M. Bhambure

Blue Star Limited

2nd Pokhran Road, Majiwada

Thane, Maharashtra, INDIA

1, Jitendra M. Bhambure, residing in Thane, Maharashtra, INDIA, as a member of the International Expert Panel for the High Ambient Testing Program, declare as follows:

1) That my responsibilities related to ODS, HFCs, or their alternatives include:

- Understanding of various refrigerants and developing refrigeration and airconditioning products, as Head of R\&D, for Blue Star Limited, INDIA.

- Neither I, nor my spouse or my children own stock or have proprietary interest in companies producing HFCs or their alternatives or substitutes.

2) My interests and those of my spouse or children related to ODS, HFCs, or their alternatives include the following:

- Research and teaching in the areas of heat transfer and sustainable energy: None

- Proprietary interests related to ODS, HFCs, or their alternatives: None

- Financial interests related to ODS, HFCs, or their alternatives: None

- Employment, consultancy, directorship, or other positions related to ODS, HFCs, or their alternatives: None, except for holding shares of Blue Star Limited, India

- Government advice and other policy development related to ODS, HFCs, or their alternatives: Participate in workshops and as ODS Sub-Committee Head of Refrigeration and Air-Conditioning Manufacturers Association of India (RAMA)

- Paid research activities, fellowships, or grants related to ODS, HFCs, or their alternatives: None

- Other interests related to ODS, HFCs, or their alternatives: None

3) I undertake to disclose any material change to any of the above information, within 30 days of any such change.

4) I undertake to make further declarations of interest needed for so long as I remain a member of this Panel.

5) I understand that this Disclosure of Interest will expire no later than one year after I have signed it.

Printed Name: Jitendra M. Bhambure

Date: September 4, 2015

\section{Signature on File}


Disclosure of Interest Declaration

International Expert Panel for the High-Ambient Testing Program

Carvalho, Suely M. Machado

Instituto de Pesquisas Energéticas e Nucleares, IPEN

São Paulo, Brazil

I, Suely M. Machado Carvalho, residing in São Paulo, SP, Brazil, as a member (co-chair) of the International Expert Panel for the High Ambient Testing Program, declare as follows:

1) That my responsibilities related to ODS, HFCs, or their alternatives include:

- Adviser to the superintendent and senior researcher in the field of technology and energy efficiency at the Instituto de Pesquisas Energéticas e Nucleares, IPEN, located at the University of São Paulo campus in São Paulo, Brazil. IPEN is a research institute of CNEN/MCTI (federal government/science and technology ministry).

- Coordinator of the Energy Efficiency Partnership programme between IPEN and the Institute of Energy and Environment (IEE) of the University of São Paulo. As such, I liaise with organizations dealing with Montreal Protocol and UNFCCC related climate issues, manufacturers of equipment and alternatives to HFCs, and industry associations.

- Invited author for the LAC Regional Assessment of Short Lived Climate Pollutants (SLCPS). Coordinated by UNEP ROLAC and Climate and Clean Air Coalition to Reduce Short Lived Climate Pollutants, CCAC.

- Neither I, nor my spouse or my children own stock or have proprietary interest in companies producing HFCs or their alternatives or substitutes.

2) My interests and those of my spouse or children related to ODS, HFCs, or their alternatives include the following:

Research on energy efficiency improvements, chemicals and policy options to mitigate climate change. None for my spouse and children.

Proprietary interests related to ODS, HFCs, or their alternatives: None Financial interests related to ODS, HFCs, or their alternatives: None Employment, consultancy, directorship, or other positions related to ODS, HFCs, or their alternatives: Half-time employment at IPEN/IEE. Short-term consultant for the World Bank (OORG). Co-chair of the International Expert Panel for the High-Ambient Testine Program (travel and DSA paid by oreanizers of the propramme, salary paid by IPEN). Government advice and other policy development related to ODS, HFCs, or their alternatives: eventual and upon request.

Paid research activities, fellowships, or grants related to ODS, HFCs, or their alternatives: None currently.

Other interests related to ODS, HFCs, or their alternatives: Providine expert advice and leadership to facilitate decision making processes that can help mitigate climate change and protect the ozone layer, and working to tap into synergies among international asreements.

3) I undertake to disclose any material change to any of the above information, within 30 days of any such change.

4) I undertake to make further declarations of interest needed for so long as I remain a member of this Panel.

5) I understand that this Disclosure of Interest will expire no later than one year after I have signed it.

Printed Name and signature: Suely Maria Machado Carvalho

Signature on File

Date: 10 June 2015 


\title{
Disclosure of Interest Declaration \\ International Expert Panel for the High-Ambient Testing Program
}

\author{
Ayman El-Talouny \\ Programme officer \\ United Nations Environment Programme, UNEP \\ Regional office for West Asia, ROWA \\ Bahrain
}

I, Ayman El-Talouny, residing in Manama- Bahrain, as a member of the International Expert Panel for the High Ambient Testing Program, managed by US Departgement of Energy, declare as follows:

1) That my responsibilities related to ODS, HFCs, or their alternatives include:

- Manage HCFC phase-out programs and projects, in developing countries, within my job responsibilities as UNEP Staff Memebr

- Coordinate international partnership and projects between UNEP and several international HVAC\&R associations and orgnizations

- Neither I, nor my spouse or my children own stock or have proprietary interest in companies producing, trading or servicing any type of refrigerants including $\mathrm{HFC}$ and their substititues.

2) My interests and those of my spouse or children related to ODS, HFCs, or their alternatives include the following:

- My interest is within my job description, as UNEP staff member, by advising governments and supporting industry/private sectors, in developing countries, to implmente projects and manage initiatives to phase-out HCFCs and minmize the use of high-GWP alterantives.

- Proprietary interests related to ODS, HFCs, or their alternatives: None

- Financial interests related to ODS, HFCs, or their alternatives: None

- Pesonally received funds or grants for relevant reserach: None

- Niether my spouse nor my children has interests in any research, commercial or policy related topic to ODS, HFCs or alterantives.

3) I undertake to disclose any material change to any of the above information, within $\mathbf{3 0}$ days of any such change and till the end of the project.

4) I undertake to make further declarations of interest needed for so long as I remain a member of this Panel.

5) I understand that this Disclosure of Interest will expire no later than one year after I have signed it.

Printed Name: Ayman T El-Talouny

Date: September 19, 2015

Signature:

Signature on File 


\section{Disclosure of Interest Declaration \\ International Expert Panel for the High-Ambient Testing Program}

\section{Tingxun Li \\ Sun Yat Sen University}

China

I, Tingxun $\mathrm{Li}$, residing in GUANGZHOU, China, as a member of the International Expert Panel for the High Ambient Testing Program, declare as follows:

1) That my responsibilities related to ODS, HFCs, or their alternatives include: I work as an associate Professor, teaching courses and doing research in the fields of thermal sciences and refrigeration and air conditioning, at Sun Yat Sen University, a comprehensive University in Guangzhou, Guangdong, China. As an expert of China national HPMP of RAC, I consult for various entities. These include organizations dealing with refrigeration and air conditioning issues, and organizations dealing with Montreal Protocol and UNFCCC related climate issues. All consultancies are conducted on a short-term assignment basis. Neither I, nor my spouse or my children own stock or have proprietary interest in companies producing HFCs or their alternatives or substitutes.

2) My interests and those of my spouse or children related to ODS, HFCs, or their alternatives include the following:

a. Proprietary interests related to $\mathrm{ODS}, \mathrm{HFCs}$, or their alternatives: $\lceil\mathrm{No}]$

b. Financial interests related to ODS, HFCs, or their alternatives: [No]

c. Employment, consultancy, directorship, or other positions related to ODS, HFCs, or their alternatives: [No]

d. Government advice and other policy development related to ODS, HFCs, or their alternatives: $[\mathrm{No}]$

e. Paid research activities, fellowships, or grants related to ODS, HFCs, or their alternatives: [No]

f. Other interests related to ODS, HFCs, or their alternatives: [No]

3) I undertake to disclose any material change to any of the above information, within 30 days of any such change.

4) I undertake to make further declarations of interest needed for so long as I remain a member of this Panel.

5) I understand that this Disclosure of Interest will expire no later than one year after I have signed it.

\section{Printed Name: Tingxun $\mathrm{Li}$}

\section{Signature:}

Signature on File

Date : 23 May,2015 


\section{Disclosure of Interest Declaration}

\section{International Expert Panel for the High-Ambient Testing Program}

Samuel F Yana Motta

Honeywell International Inc.

USA

I, Samuel F Yana Motta, residing in Buffalo NY, USA, as a member of the International Expert Panel for the High Ambient Testing Program, declare as follows:

1) That my responsibilities related to ODS, HFCs, or their alternatives include:

- Director of Technology (refrigerants) for Honeywell International, where I direct $R \& D$ activities.

2) My interests related to ODS, HFCs, or their alternatives include the following:

- Research in the areas of heat transfer and development of heat transfer for HVAC applications.

- Proprietary interests related to ODS, HFCs, or their alternatives: None

- Financial interests related to ODS, HFCs, or their alternatives: None

- Other interests related to ODS, HFCs, or their alternatives: None currently

3) I undertake to disclose any material change to any of the above information, within 30 days of any such change.

4) I undertake to make further declarations of interest needed for so long as I remain a member of this Panel.

5) I understand that this Disclosure of Interest will expire no later than one year after I have signed it.

Printed Name: Samuel F Yana Motta

Date: September 22, 2015

Signature: Signature on File 


\section{Disclosure of Interest Declaration International Expert Panel for the High-Ambient Testing Program}

Maher H. Mousa

Consultant, HVACR Industry and Environmental Policy

The Consultancy Office of Maher H. Mousa

Jeddah, Saudi Arabia

I, Maher H. Mousa, located in Jeddah, Saudi Arabia, as a member of the International Expert Panel for the High Ambient Testing Program, declare as follows:

1) That my responsibilities related to ODS, $\mathrm{HFCs}$, or their alternatives include:

- Consultancy, HVAC Product development, program management, testing laboratories, technology transfer and energy and environmental regulations, under my private consultancy office located in Jeddah, Saudi Arabia.

- Neither I, nor my spouse or my children own stock or have proprietary interest in companies producing HFCs or their alternatives or substitutes.

2) My interests and those of my spouse or children related to ODS, HFCs, or their alternatives include the following:

- Consultancy, to private and public sectors on short tasks bases.

- Business research for my MBA degree at University of Leicester, UK.

- Proprietary interests related to ODS, HFCs, or their alternatives: None

- Financial interests related to ODS, HFCs, or their alternatives: None

- Employment, directorship, or other positions related to ODS, HFCs, or their alternatives: None

- Government advice and other policy development related to ODS, HFCs, or their altematives: technical advisory in my capacity as a consultant, on short tasks bases

- Paid research activities, fellowships, or grants related to ODS, HFCs, or their alternatives: None currently

- Other interests related to ODS, HFCs, or their alternatives: None currently

3) I undertake to disclose any material change to any of the above information, within 30 days of any such change.

4) I undertake to make further declarations of interest needed for so long as I remain a member of this Panel.

5) I understand that this Disclosure of Interest will expire no later than one year after I have signed it.

Printed Name: Maher $\mathbf{H}$

Date: September 8, 2019 Signature on File 


\section{Disclosure of Interest Declaration International Expert Panel for the High-Ambient Testing Program}

Ole Reinholdt Nielsen

United Nations Industrial Development Organization, UNIDO

Austria

I, Ole Reinholdt Nielsen, residing in Vienna, Austria, as a member of the International Expert Panel for the High Ambient Testing Program, declare as follows:

1) That my responsibilities related to ODS, HFCs, or their alternatives include: I work as Chief of the Montreal Protocol Unit within the Environmental Branch of UNIDO. The overall objective of the work is to assist developing countries - at their request - in meeting their obligations within the framework of the Montreal Protocol on Substances that Deplete the Ozone Layer. The assistance comprise: a) Support in drafting a country strategy to phase-out ODS as per Montreal Protocol schedule; including necessary policy requirements; institutional activities and investment components; b) Ensure funding for the before-mentioned strategy from the Multilateral Fund of the Montreal Protocol; and c) implement the before-mentioned strategy in accordance with the agreed schedule of activities. All advices given are based on Montreal Protocol eligibility and modus operandi; and are fully neutral towards specific substances, processes and equipment.

2) My interests and those of my spouse or children related to ODS, HFCs, or their alternatives include the following:

a. Proprietary interests related to ODS, HFCs, or their alternatives: Neither I, nor my spouse or my children have proprietary interests related to ODS, HFCs or their alternatives.

b. Financial interests related to ODS, HFCs, or their alternatives: Neither I, nor my spouse or my children have financial interests related to ODS, HFCs or their alternatives.

c. Employment, consultancy, directorship, or other positions related to ODS, HFCs, or their alternatives: In addition to what has been specified under paragraph 1) above; neither I, nor my spouse or my children have employment, consultancy, directorship, or other positions related to ODS, HFCs or their alternatives.

d. Government advice and other policy development related to ODS, HFCs, or their alternatives: In addition to what has been specified under paragraph 1) above; neither I, nor my spouse or my children provide government advices and other policy development activities related to ODS, HFCs or their alternatives.

e. Paid research activities, fellowships, or grants related to ODS, HFCs, or their alternatives: Neither I, nor my spouse or my children have paid research activities, fellowships, or grants related to ODS, HFCs or their alternatives.

f. Other interests related to ODS, HFCs, or their alternatives: Neither I, nor my spouse or my children have other interests related to ODS, HFCs or their alternatives. 
3) I undertake to disclose any material change to any of the above information, within 30 days of any such change.

4) I undertake to make further declarations of interest needed for so long as I remain a member of this Panel.

5) I understand that this Disclosure of Interest will expire no later than one year after I have signed it.

\section{Printed Name: Ole Reinholdt Nielsen}

Signature: Signature on File

Date : August 25, 2015 


\title{
Disclosure of Interest Declaration \\ International Expert Panel for the High-Ambient Testing Program
}

\author{
Tetsuji Okada \\ Japan Refrigeration and Air conditioning Industry Association \\ Japan
}

I, Tetsuji Okada, residing in Tokyo, Japan, as a member of the International Expert Panel for the High Ambient Testing Program, declare as follows:

1) That my responsibilities related to ODS, HFCs, or their alternatives include: I work as the president of JRAIA, managing the development or research of the equipment or refrigerants. I have been a member of the UNEP RTOC from 2013. I have engaged in the research and development of the air conditioners and the hot water systems by $\mathrm{CO} 2$ (Eco cute). I am also familiar with the heat exchangers used in the air conditioners and the refrigerant circuits of the heat pump systems.Neither I, nor my spouse or my children own stock or have proprietary interest in companies producing HFCs or their alternatives or substitutes.

2) My interests and those of my spouse or children related to ODS, HFCs, or their alternatives include the following:

a. Proprietary interests related to ODS, HFCs, or their alternatives: [None]

b. Financial interests related to ODS, HFCs, or their alternatives: [None]

c. Employment, consultancy, directorship, or other positions related to ODS, HFCs, or their alternatives: [described in number 1 above]

d. Government advice and other policy development related to ODS, HFCs, or their alternatives: [None]

e. Paid research activities, fellowships, or grants related to ODS, HFCs, or their alternatives: [None]

f. Other interests related to ODS, HFCs, or their alternatives: [None]

3) I undertake to disclose any material change to any of the above information, within 30 days of any such change.

4) I undertake to make further declarations of interest needed for so long as I remain a member of this Panel.

5) I understand that this Disclosure of Interest will expire no later than one year after I have signed it.

Printed Name:

Tetsuji Okada

Signature on File

Date :01-06-2015 


\section{Disclosure of Interest Declaration \\ International Expert Panel for the High-Ambient Testing Program}

Dr M. Alaa Olama

Independent consultant

Egypt.

I, Dr Olama, residing in Cairto, Egypt, as a member of the International Expert Panel for the High Ambient Testing Program, declare as follows:

1) That my responsibilities related to ODS, HFCs, or their altematives include:

2) I work as an independent Refrigeration and Air Conditioning Consultant, providing consultancy services in the fields of refrigeration and air conditioning and thermal sciences. As an expert I consult for various entities. These include organizations dealing with refrigeration and air conditioning issues, and organizations dealing with Montreal Protocol and UNFCCC related climate issues. All consultancies are conducted on a shortterm assignment basis. Neither I, nor my spouse or my children own stock or have proprietary interest in companies producing HFCs or their alternatives or substitutes.

3) My interests and those of my spouse or children related to ODS, HFCs, or their alternatives include the following:

None.

4) I undertake to disclose any material change to any of the above information, within 30 days of any such change.

5) I undertake to make further declarations of interest needed for so long as I remain a member of this Panel.

6) I understand that this Disclosure of Interest will expire no later than one year after I have signed it.

Printed Name: Dr M. Alaa A. Olama

Signature: Signature on File

Date :28th May 2015 
Disclosure of Interest Declaration

International Expert Panel for the High-Ambient Testing Program

Alessandro Giuliano Peru

Department of Environment

CUEIM (University Consortium for Industrial Economy and Management)

Rome

ITALY

I. Alessandro Giuliano Peru, residing in Rome, ITALY, as a member of the International Expert Panel for the High Ambient Testing Program, declare as follows:

1) That my responsibilities related to ODS, HFCs, or their alternatives include:

- Programme manager for several pubblications and papers in relation to the managment of chemical substances, including those who harm the climate change and deplete the ozone layer. Past President of the EU Italian Presidency of the Intemational Ozone group and Senior Environemntal Expert for the Italian Ministry of the Environment, Land and the Sea.

- Member of the European Association for the refrigeration and air conditioning (AREA)

- Neither I, nor my spouse or my children own stock or have proprietary interest in companies producing $\mathrm{HFCs}$ or their alternatives or substitutes.

2) My interests and those of my spouse or children related to ODS, HFCs, or their alternatives include the following:

- Proprietary interests related to ODS, HFCs, or their altematives: None

- Financial interests related to ODS, HFCs, or their alternatives: None

- Employment, consultancy, directorship, or other positions related to ODS, HFCs, or their alternatives: None

- Government advice and other policy development related to ODS, HFCs, or their alternatives: yes

- Paid research activities, fellowships, or grants related to ODS, HFCs, or their alternatives: None currently

- Other interests related to ODS, HFCs, or their altematives: None currently

3) I undertake to disclose any material change to any of the above information, within 30 days of any such change.

4) I undertake to make further declarations of interest needed for so long as I remain a member of this Panel.

5) I understand that this Disclosure of Interest will expire no later than one year after I have signed it.

Printed Name: Alessandro Giuliano Peru

Date: May 16, 2015

Signature: Signature on File 


\section{Disclosure of Interest Declaration \\ International Expert Panel for the High-Ambient Testing Program}

Patrick E. Phelan

Department of Energy, Building Technologies Office

Arizona State University, School for Engineering of Matter, Transport \& Energy

USA

I, Patrick E. Phelan, residing in Arlington, Virginia, USA, as a member (co-chair) of the International Expert Panel for the High Ambient Testing Program, declare as follows:

1) That my responsibilities related to ODS, HFCs, or their alternatives include:

- Manager, Emerging Technologies Program, Building Technologies Office, US Department of Energy, where I direct R\&D activities on building energy technologies, including HVAC, refrigeration, appliances, windows, lighting, etc.

- Professor of Mechanical \& Aerospace Engineering, and Senior Sustainability Scientist, Arizona State University, where I conduct research and teach in areas of heat transfer and sustainable energy

- Neither I, nor my spouse or my children own stock or have proprietary interest in companies producing HFCs or their alternatives or substitutes.

2) My interests and those of my spouse or children related to ODS, HFCs, or their alternatives include the following:

- Research and teaching in the areas of heat transfer and sustainable energy; my spouse has research interests in urban heat island and its impacts on economics and health; none for my children

- Proprietary interests related to ODS, HFCs, or their alternatives: None

- Financial interests related to ODS, HFCs, or their alternatives: None

- Employment, consultancy, directorship, or other positions related to ODS, HFCs, or their alternatives: None

- Government advice and other policy development related to ODS, HFCs, or their alternatives: Provide research advice through the course of my DOE position

- Paid research activities, fellowships, or grants related to ODS, HFCs, or their alternatives: None currently

- Other interests related to ODS, HFCs, or their alternatives: None currently

3) I undertake to disclose any material change to any of the above information, within 30 days of any such change.

4) I undertake to make further declarations of interest needed for so long as I remain a member of this Panel.

5) I understand that this Disclosure of Interest will expire no later than one year after I have signed it.

Printed Name: Patrick E. Phelan

Date: September 4, 2015

Signature: Signature on File 